\title{
Decontamination and Dismantlement of the JANUS Reactor at Argonne National Laboratory-East Project Final Report
}
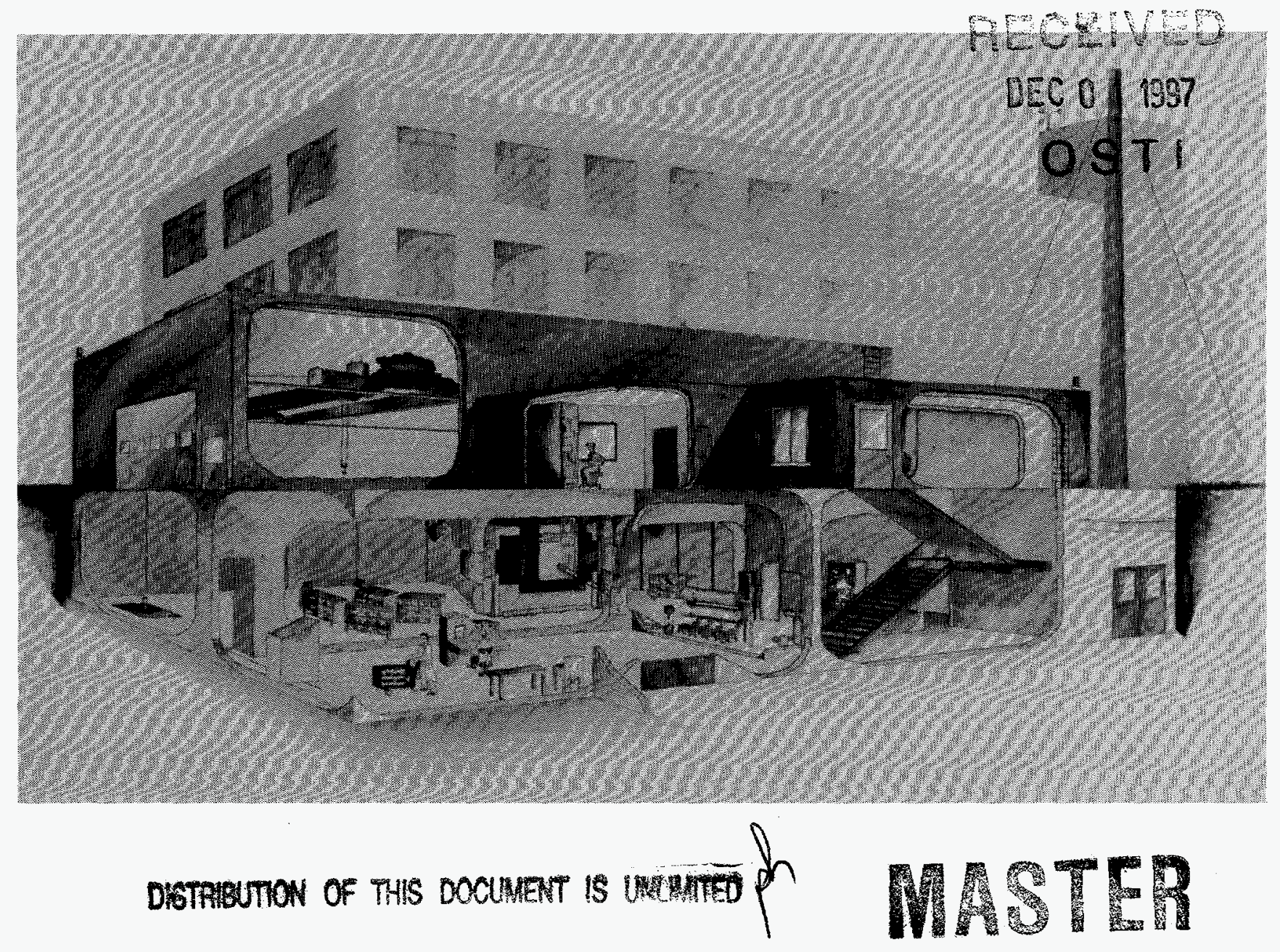

\section{Decontamination and Decommissioning Program}

Argonne National Laboratory

9700 South Cass Avenue

Argonne, Illinois 60439
Operated by The University of Chicago, under Contract W-31-109-ENG-38, for the United States Department of Energy 


\section{Argonne National Laboratory}

Argonne National Laboratory, with facilities in the states of Illinois and Idaho, is owned by the United States Government, and operated by the University of Chicago under the provisions of a contract with the Department of Energy.

This final project repor: is a product of Argonne's Technology Development Division, Decontamination and Decommissioning Program. For information on the division's activities, contact:

Director, Technology Development Division

Argonne National Laboratory

Argonne, Illinois 60439-4841

Telephone (630) 25i2-6050

\section{Disclaimer}

This report was prepared as an account of work sponsored by an agency of the United States Government. Neither the United States Government nor any agency thereof, nor any of their employees, makes any warranty, express or implied, or assumes any legal liability or responsibility for the accuracy, completeness, or usefulness of any information, apparatus, product, or process disclosed, or represents that its use would not infringe privately owned rights. Reference herein to any specific commercial product, process, or service by trade name, trademark, manufacturer, or otherwise, does not necessarily constitute or imply its endorsement, recommendation, or favoring by the United States Government or any agency thereof. The views and opinions of authors expressed herein do not necessarily state or reflect those of the United States Government or any agency thereof.

Available to DOE and DOE contractors from the Office of Scientific and Technical Information, P.O. Box 62, Oak Ridge, TN 37831; prices available from (423) 576-8401.

Available to the public from the National Technical Information Service, U.S. Department of Commerce, 5285 Port Royal Road, Springfield, VA 22161. 


\section{DESCLAmixR}

Portions of this docoment ongy be Illegible in electronic image produets. Imoges are produced from the best available origion docementert 
Decontamination and Dismantlement of the

JANUS Reactor at Argonne National Laboratory-East

Project Final Report
C. R. Fellhauer
G. A. Garlock*
F. R. Clark

Decontamination and Decommissioning Program, Technology Development Division, Argonne National Laboratory, 9700 South Cass Avenue, Argonne, Illinois 60439

October 1997

Work sponsored by United States Department of Energy, Office of Environmental Management

${ }^{*}$ Garlock is affiliated with MOTA Corporation, South Carolina 


\section{TABLE OF CONTENTS}

\section{Page}

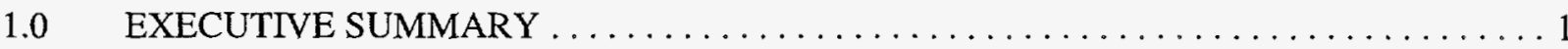

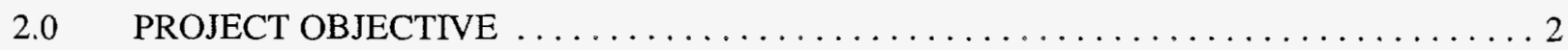

3.0 FACILITY HISTORY AND DESCRIPTION $\ldots \ldots \ldots \ldots \ldots \ldots \ldots \ldots \ldots \ldots$

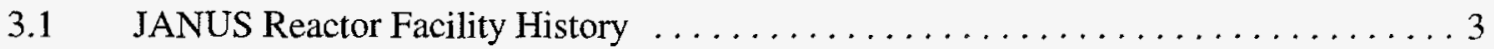

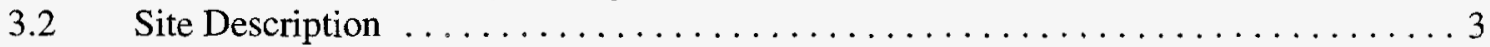

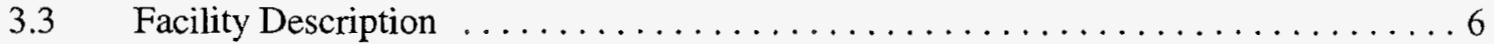

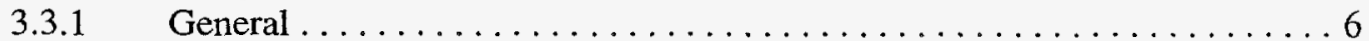

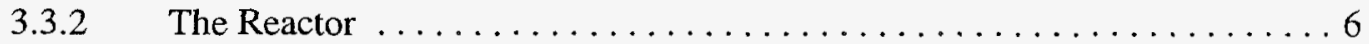

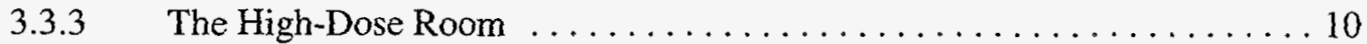

3.3.4 The Low-Dose Room . . . . . . . . . . . . . . . . . . . 10

3.3.5 Converter Plates . . . . . . . . . . . . . . . . . . . . 10

3.3.6 Neutron and Gamma Shields ....................... 10

3.3.7 Rabbit Tube ............................... 11

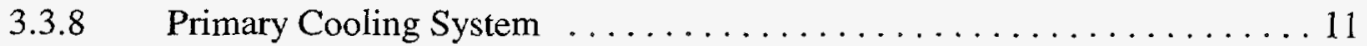

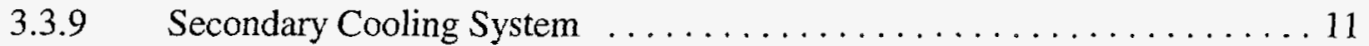

3.3.10 Primary Coolant Purification System . . . . . . . . . . . . . . 11

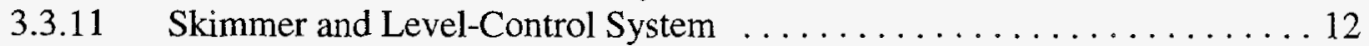

3.3 .12 Helium Systems . . . . . . . . . . . . . . . . . . 12

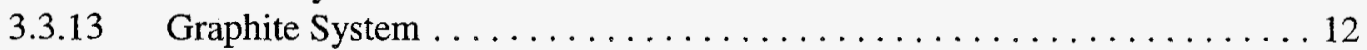

4.0 OVERVIEW OF THE JANUS D\&D PROJECT $\ldots \ldots \ldots \ldots \ldots \ldots \ldots \ldots \ldots \ldots$

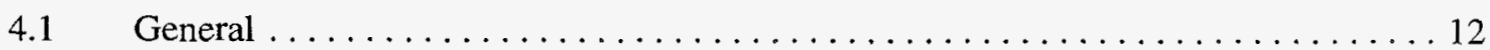

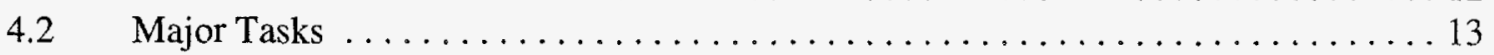

5.0 JANUS D\&D PROJECT PLANNING AND ENGINEERING $\ldots \ldots \ldots \ldots \ldots \ldots \ldots \ldots$

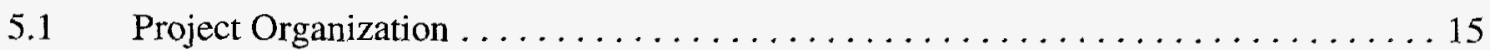

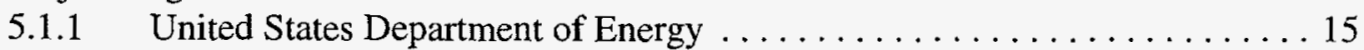

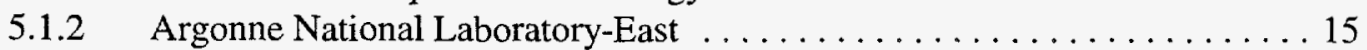

$5.1 .3 \quad$ D\&D Field Work . . . . . . . . . . . . . . . . . . . . . . . 15

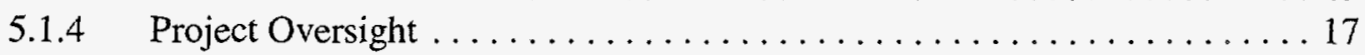

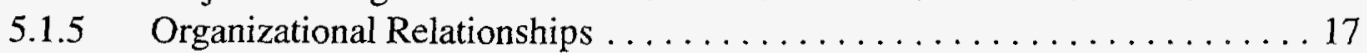

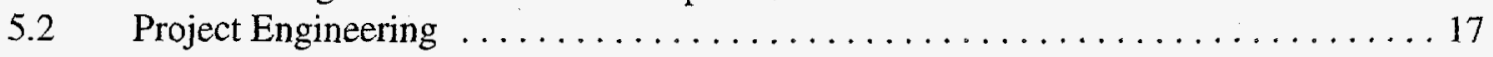

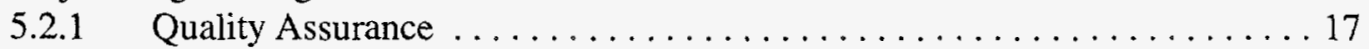

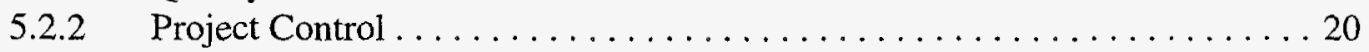

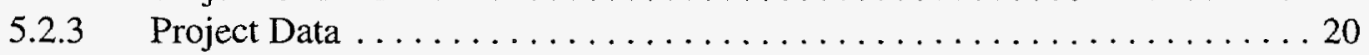

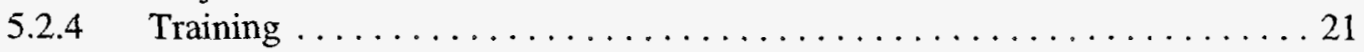


Janus D\&D Project

Final Report

Page iv of $x$

Page

5.2.5 Health and Safety . . . . . . . . . . . . . . . . . . . . . . . 22

5.2.5.1 Environment, Safety and Health Policy .............. 22

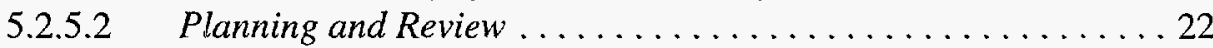

5.2.5.3 Radiation Safety . . . . . . . . . . . . . . . . 22

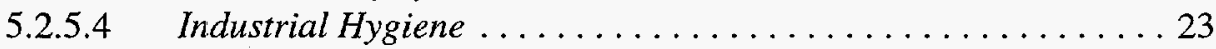

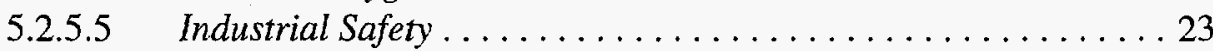

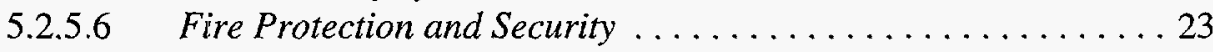

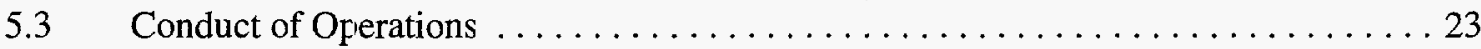

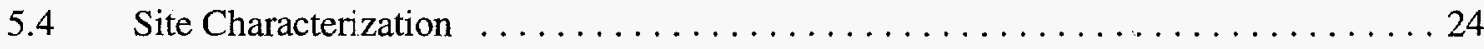

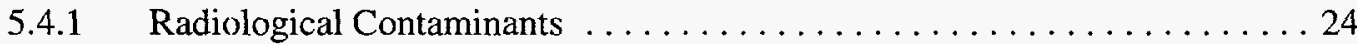

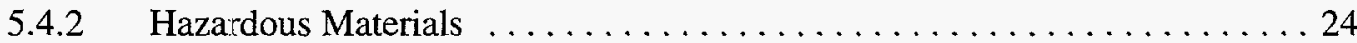

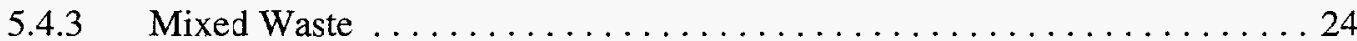

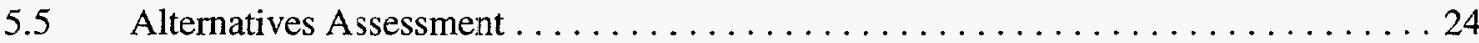

6.0 DECONTAMINATION AND DISASSEMBLY OPERATIONS $\ldots \ldots \ldots \ldots \ldots \ldots \ldots$

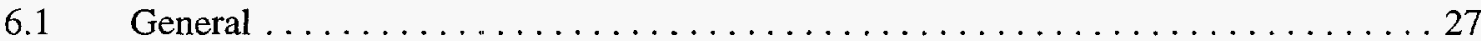

6.2 Pre-Subcontractor Preparation and Characterization $\ldots \ldots \ldots \ldots \ldots \ldots \ldots \ldots 27$

$6.2 .1 \quad$ Project Preparations .............................. 27

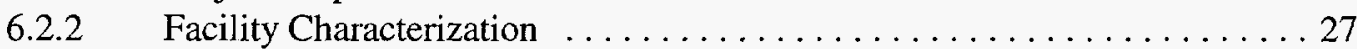

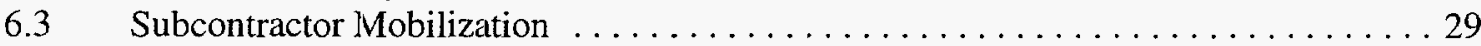

$6.3 .1 \quad$ Contract Award ... . . . . . . . . . . . . . . . . . . . . . . . . . . . 29

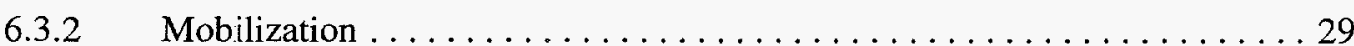

$6.3 .3 \quad$ H-Wing Set-Up . . . . . . . . . . . . . . . . . . . . . . 29

6.3.4 Pre-Work Bioassay and Whole Body Count . . . . . . . . . . . . . 29

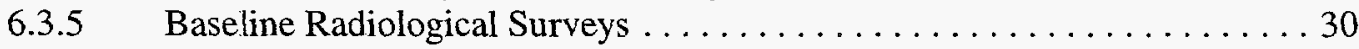

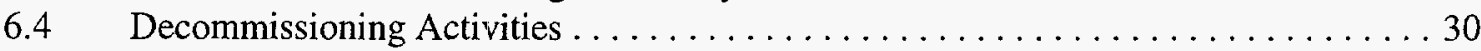

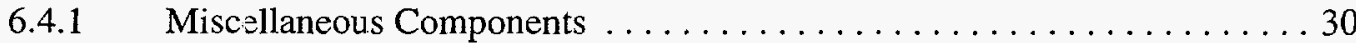

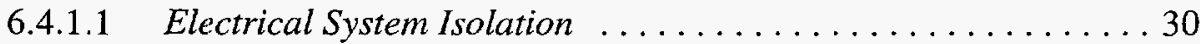

6.4 .1 .2 Asbestos Abatement . . . . . . . . . . . . . . . . . . 30

6.4.1.3 Exhaust Stack Removal . . . . . . . . . . . . . . . . . 33

6.4.1.4 Cooling Tower Removal ...................... 33

6.4.1.5 Glovebox Removal............................ 33

6.4.1.6 Lead-Based Paint Removal ....................... 33

6.4.2 High-Dose Room Demolition ... . . . . . . . . . . . . . . . . . . . . 38

6.4.2.1 Floor Lead Removal ... . . . . . . . . . . . . . . . . . 38

6.4.2.2 Wall Lead Removal ... . . . . . . . . . . . . . . . . . . . . 39

6.4.2.3 Hardboard Removal ........................... . 39

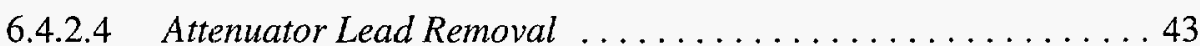

6.4.2.5 Ceiling Lead Removal . . . . . . . . . . . . . . . . . . . . . 43

6.4.2.6 Ceiling and Equipment Removal ................ 43

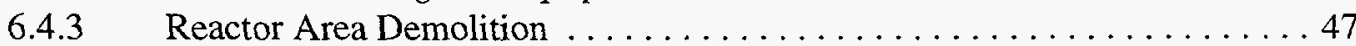

6.4.3.1 Shielded Floor Plug Removal .................... . 47

6.4.3.2 Containment Installation .......................47 
6.4.3.3 Piping and Equipment Removal from Above

the Reactor .............................44 47

6.4.3.4 Reactor Shield Plug Removal ................47

6.4.3.5 Attenuator Tank Removal .................... 52

6.4.3.6 Reactor Internals Removal ...................... 52

6.4.3.7 Rabbit Tube Assembly Removal ... . . . . . . . . . . . . . . 52

6.4.3.8 Reactor Tank Removal ......................... 52

6.4 .3 .9 Graphite Removal ........................... 56

6.4 .3 .10 Steel Shell Removal .......................... 56

6.4.4 High- and Low-Dose Shutter System Removal . . . . . . . . . . . . . . 56

6.4.4.1 High-Dose Shutter Drive Removal . . . . . . . . . . . . 59

6.4.4.2 Low-Dose Shutter Drive Removal . . . . . . . . . . . . . . . . . 59

6.4.4.3 High-Dose Shutter and Pedestal Removal............. 59

6.4.4.4 Low-Dose Shutter and Pedestal Removal ............... 59

$6.4 .5 \quad$ Activated Structure Removal ......................... 63

6.4.5.1 Activated Bioshield Removal ...................663 63

6.4.5.2 Converter Frame Removal ......................63 63

6.4.5.3 Gamma Attenuator Pedestal Removal .................6 63

6.4.6 Control Room Facilities Removal . . . . . . . . . . . . . . . . . . . 63

6.4.6.1 Low-Dose Room Control Panel Removal . . . . . . . . . . . . . 65

6.4.6.2 High-Dose Room Control Panel Removal ..............665

6.4.6.3 Reactor Control Console Removal ..................665

6.4.6.4 Experimental Equipment Removal .................665

$6.4 .7 \quad$ Systems Removal . . . . . . . . . . . . . . . . . . . . . . . . . . 65

6.4.7.1 Secondary Cooling System Removal ................ 69

6.4.7.2 Primary Water System Removal . . . . . . . . . . . . . . . . 69

6.4 .7 .3 Helium System Removal ... . . . . . . . . . . . . . . . 69

6.4.7.4 Level Control and Skimmer System Removal ... . . . . . . . 69

$6.4 .8 \quad$ Storage Facilities and Excess Material . . . . . . . . . . . . . 70

6.4.8.1 Spent Fuel Transfer Cask Removal . . . . . . . . . . . . . 70

6.4.8.2 Excess Lead Removal . . . . . . . . . . . . . . . . 70

$6.4 .8 .3 \quad$ Seal Pipe Tunnel . . . . . . . . . . . . . . . . . . 70

6.4.8.4 Decontaminating and Sealing the Fuel

Storage Tubes ............................ 70

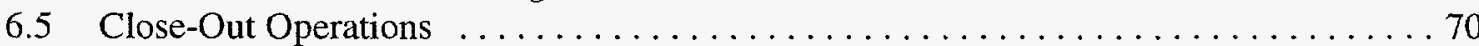

6.5.1 Decontaminate and Wipe Down Surfaces . . . . . . . . . . . . . . 70

6.5.2 Perform Final Survey . . . . . . . . . . . . . . . . . . 70

6.5.3 Obtain and Analyze Samples . . . . . . . . . . . . . . . . . . . 71

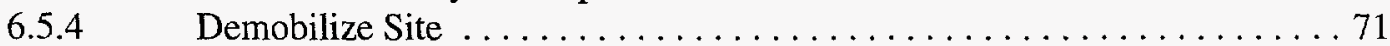

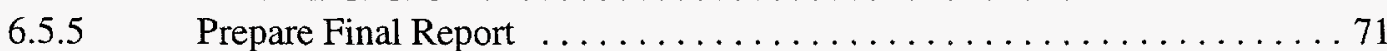


Janus D\&D Project

Final Report

Page vi of $x$

$\underline{\text { Page }}$

$7.0 \quad$ POST-DECOMMISSIONING RADIOLOGICAL SURVEY $\ldots \ldots \ldots \ldots \ldots \ldots \ldots \ldots 71$

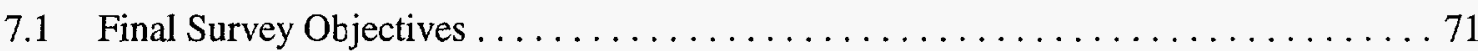

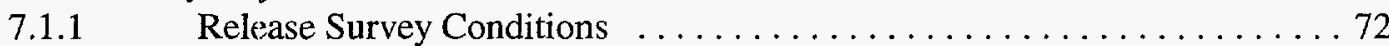

7.1.2 Unrestricted Release Criteria . . . . . . . . . . . . . . . . . . 72

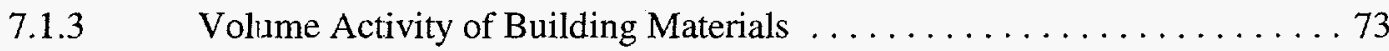

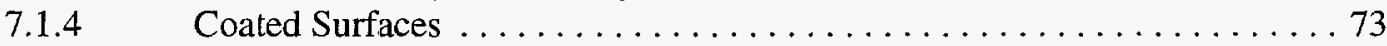

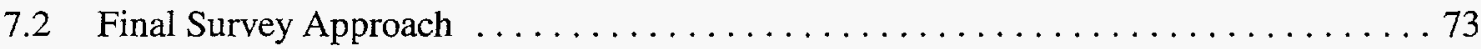

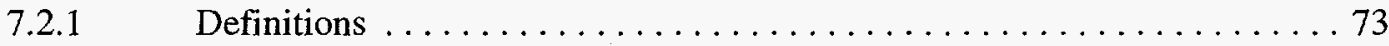

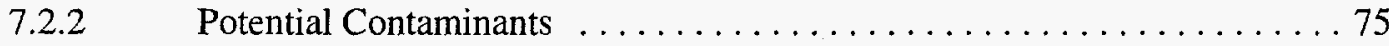

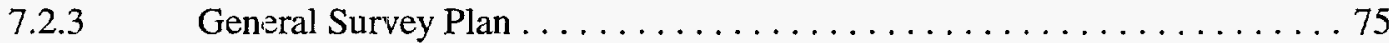

7.2.3.1 Survey Area Classifications . . . . . . . . . . . . . . . . 75

7.2.3.2 Scope of Surveys ....................... 76

7.3 Reference Grid System . . . . . . . . . . . . . . . . . . . . . . 79

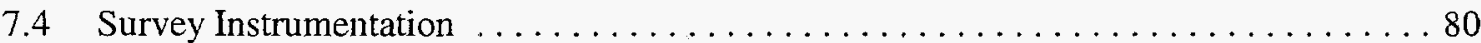

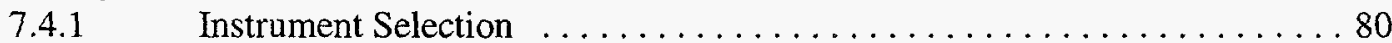

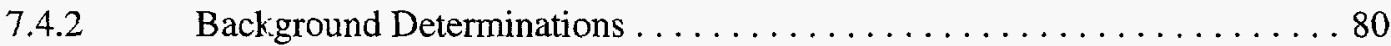

7.4.3 Daily Instrument Function Test and Quality Assurance . . . . . . . . . . . 80

7.5 Survey Methodology . . . . . . . . . . . . . . . . . . . . . . . . . . . . . 80

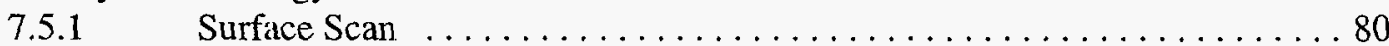

7.5.2 Direct Measurements ............................ 81

7.5.3 Removable Contamination Measurements . . . . . . . . . . . . . . 81

7.5.4 Exposure Rate Measurements $\ldots \ldots \ldots \ldots \ldots \ldots \ldots \ldots \ldots \ldots . \ldots \ldots$

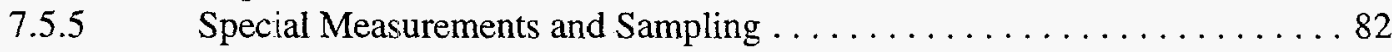

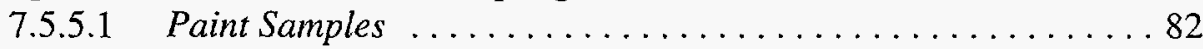

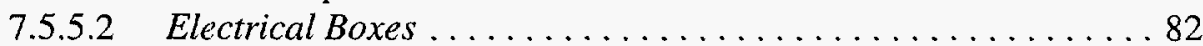

7.5.5.3 Concrete Samples ..................... 82

7.5.5.4 Drain Surfaces and Penetrations ............... 82

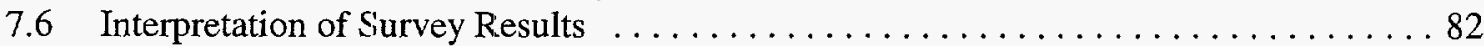

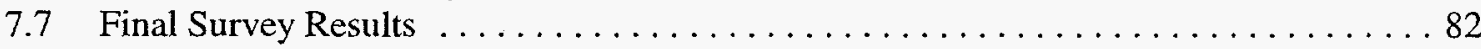

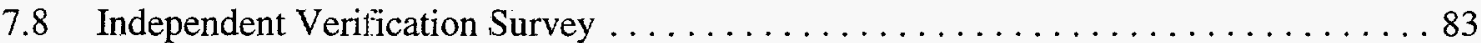

7.9 Post D\&D Hazarclous Material Condition . . . . . . . . . . . . . . . . . . . . 83

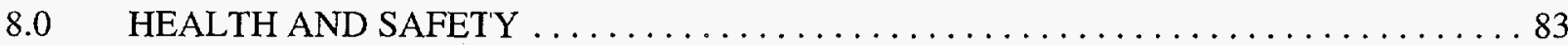

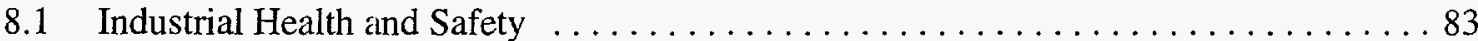

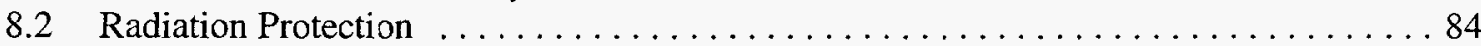

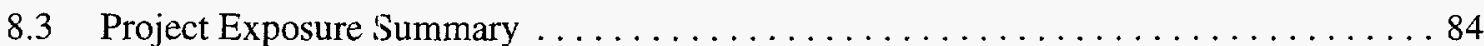

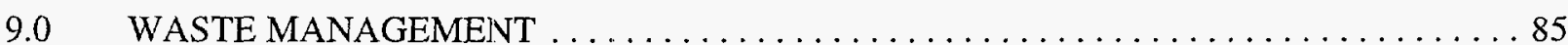

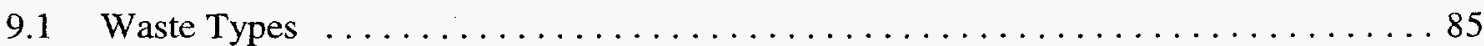

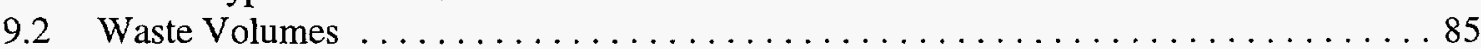

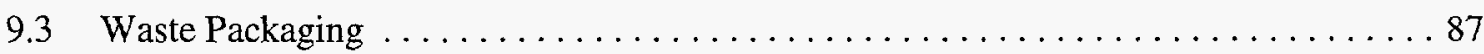




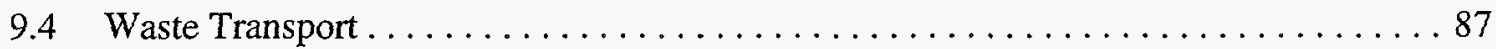

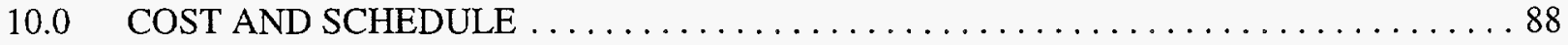

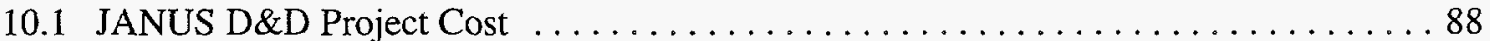

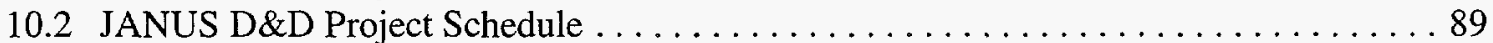

11.0 FINAL FACILITY CONDITION $\ldots \ldots \ldots \ldots \ldots \ldots \ldots \ldots \ldots \ldots \ldots \ldots \ldots \ldots$

12.0 CONCLUSIONS, RECOMMENDATIONS AND LESSONS LEARNED . . . . . . . . 97

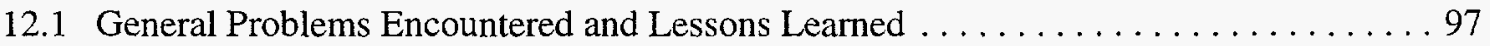

12.1.1 Cutting Live Wires . . . . . . . . . . . . . . . . . . . 97

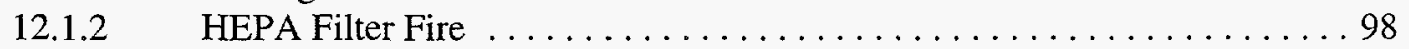

12.1.3 Crane Damages Condensate Piping . . . . . . . . . . . . . . . 99

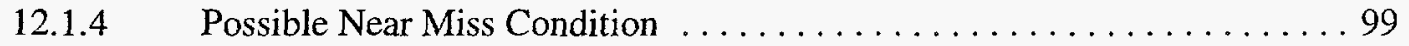

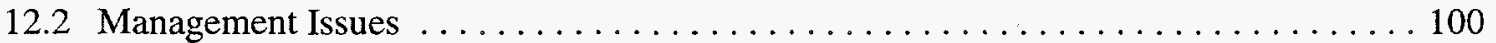

12.3 Noteworthy Practices . . . . . . . . . . . . . . . . . . . . . 100

12.3.1 Air Conditioning . . . . . . . . . . . . . . . . . . . . . . . . . . 100

12.3.2 Chain Saw Segmentation of Lead Block . . . . . . . . . . . . . . . . . . 101

12.3.3 Semi-Remote Concrete Removal . . . . . . . . . . . . . . . . . . . 101

12.3.4 Frequent Safety Inspections . . . . . . . . . . . . . . . . . . . . . 101

13.0 ACRONYM AND ABBREVIATION LISTING $\ldots \ldots \ldots \ldots \ldots \ldots \ldots \ldots \ldots \ldots \ldots$

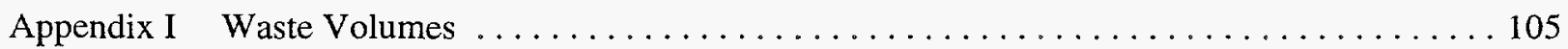

Table 1A: $\quad$ Low-Level Waste From JANUS D\&D Project $\ldots \ldots \ldots \ldots \ldots \ldots$

Table 1B: $\quad$ Mixed Waste from JANUS D\&D Project $\ldots \ldots \ldots \ldots \ldots \ldots \ldots \ldots 11$ 


\section{LIST OF TABLES}

$\underline{\text { Page }}$

Table 5.1 Nuclides Found During Characterization and Performance of

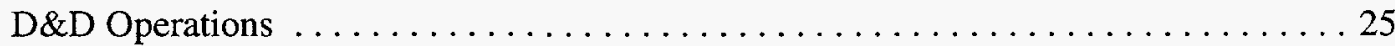

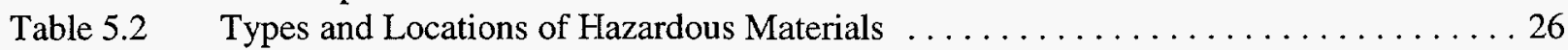

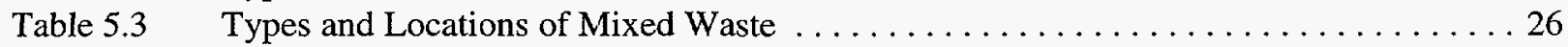

Table $6.1 \quad$ Location of Asbestos-Containing Materials (ACM) $\ldots \ldots \ldots \ldots \ldots \ldots \ldots \ldots \ldots$

Table $6.2 \quad$ Items Identified As Having Lead-Based Paint $\ldots \ldots \ldots \ldots \ldots \ldots \ldots \ldots \ldots \ldots$

Table $7.1 \quad$ Survey Area Identification and Classification $\ldots \ldots \ldots \ldots \ldots \ldots \ldots \ldots \ldots$

Table $9.1 \quad$ Waste and Recoverable Material Removed From the JANUS $\ldots \ldots \ldots \ldots \ldots$ Reactor Facility 


\section{LIST OF FIGURES}

$\underline{\text { Page }}$

Figure 3.1

Figure 3.2

Figure 3.3

Figure 3.4

Figure 3.5

Figure 5.1

Figure 5.2

Figure 5.3

Figure 6.1

Figure 6.2

Figure 6.3

Figure 6.4

Figure 6.5

Figure 6.6

Figure 6.7

Figure 6.8

Figure 6.9

Figure 6.10

Figure 6.11

Figure 6.12

Figure 6.13

Figure 6.14

Figure 6.15

Figure 6.16

Figure 6.17

Figure 6.18

Figure 6.19

Figure 6.20

Figure 6.21

Figure 6.22

Figure 6.23

Figure 6.24

Figure 6.25

Figure 6.26

Figure 6.27

Figure 6.28

Figure 6.29

Figure 6.30

Figure 6.31

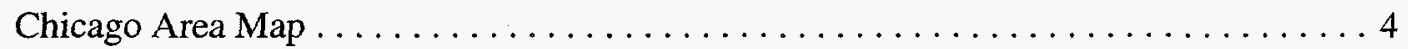

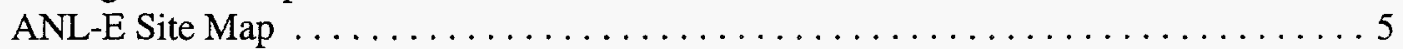

JANUS Reactor Facility Main Floor Layout $\ldots \ldots \ldots \ldots \ldots \ldots \ldots \ldots \ldots \ldots \ldots \ldots \ldots \ldots \ldots$

JANUS Reactor Facility Service Floor Layout $\ldots \ldots \ldots \ldots \ldots \ldots \ldots \ldots$

Elevation Cross Section of the JANUS Reactor Facility $\ldots \ldots \ldots \ldots \ldots \ldots \ldots$

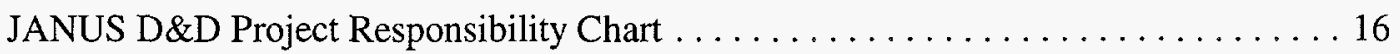

Relationship of JANUS D\&D Project to Argonne

National Laboratory-East . . . . . . . . . . . . . . . . . . . . . . 18

Relationship of JANUS D\&D Project to Subcontractors $\ldots \ldots \ldots \ldots \ldots \ldots \ldots$

JANUS D\&D Project Work Breakdown Structure $\ldots \ldots \ldots \ldots \ldots \ldots \ldots \ldots \ldots$

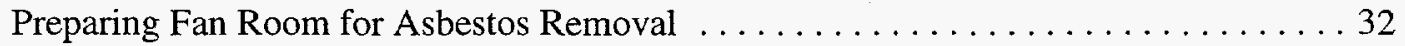

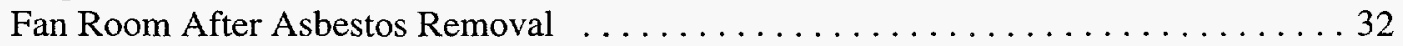

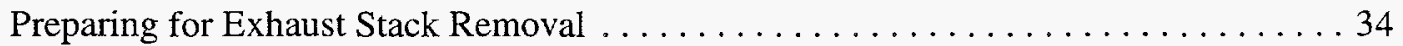

Exhaust Stack Being Removed . . . . . . . . . . . . . . . . . . . . . . . . 34

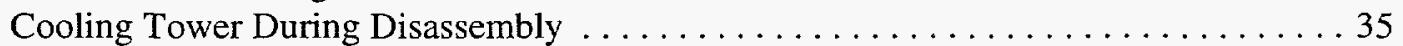

Technicians Removing Cooling Coils . . . . . . . . . . . . . . . . . . . 35

Relocating Glovebox from Room J-120 to Containment for Disassembly . . . . . . 36

Partially Disassembled Glovebox Inside Containment . . . . . . . . . . . . . 36

Stripping Lead-Based Paint From a Floor Plug . . . . . . . . . . . . . . . . 37

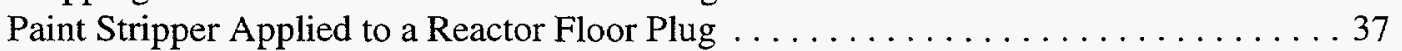

Removing Lead Bricks from High-Dose Room Floor . . . . . . . . . . . . . . . . . . 40

Radiological Control Technician Surveying Floor Lead After Removal . . . . . . . . . 40

High-Dose Room Lead Wall Block Showing Full Depth Joint Weld . . . . . . . . . 41

Sawing Lead Blocks with Electric Chain Saw . . . . . . . . . . . . . . . . 41

View of High-Dose Room During Hardboard Removal $\ldots \ldots \ldots \ldots \ldots \ldots \ldots \ldots 4$

Hardboard Removal in High-Dose Room . . . . . . . . . . . . . . . . . . . . . 42

Removing Attenuator Lead from Low-Dose Face . . . . . . . . . . . . . . . . . . . 44

Low-Dose Face at Completion of Attenuator Lead Removal . . . . . . . . . . . . . 44

Technicians Removing Ceiling Lead from High-Dose Room . . . . . . . . . . . . . . 45

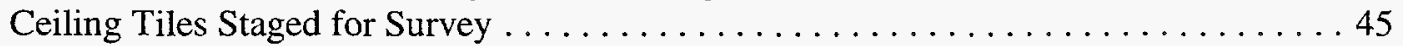

Borobauxite Concrete Ceiling in High-Dose Room Prior to Removal . . . . . . . . 46

High-Dose Room Ceiling Partially Removed . . . . . . . . . . . . . . . . . 46

Reactor Area Floor Plug Being Removed . . . . . . . . . . . . . . . . . . . 48

Preparing to Move Floor Plug Outside for Storage $\ldots \ldots \ldots \ldots \ldots \ldots \ldots \ldots$

Containment Tent Over High-Dose Room Floor Opening . . . . . . . . . . . . . . 49

Containment Set-Up Over Reactor Opening . . . . . . . . . . . . . . . . . . . . 49

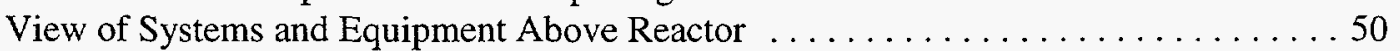

Technicians Removing Equipment From the Top of the Reactor . . . . . . . . . 50

Reactor Shield Plug Being Lifted from Containment $\ldots \ldots \ldots \ldots \ldots \ldots \ldots \ldots \ldots$

Loading Reactor Shield Plug into Waste Container $\ldots \ldots \ldots \ldots \ldots \ldots \ldots \ldots$ 
Figure 6.32 View of Reactor Internals Prior to Removal $\ldots \ldots \ldots \ldots \ldots \ldots \ldots \ldots \ldots \ldots \ldots$

Figure 6.33 Technician Using, Long-Handled Socket During Removal of Reactor Internals . . . . . . . . . . . . . . . . . . . . . . 53

Figure 6.34 Technicians Installing Contamination Controls Prior to Rabbit Tube Removal . . . . . . . . . . . . . . . . . . . . . . . . . . . . . 54

Figure 6.35 Technicians Removing Rabbit Tube Shield Plug $\ldots \ldots \ldots \ldots \ldots \ldots \ldots \ldots \ldots$

Figure 6.36 Reactor Tank Being Lifted From Reactor Cavity $\ldots \ldots \ldots \ldots \ldots \ldots \ldots \ldots \ldots$

Figure 6.37 Technician Performing Radiation Surveys on Reactor Tank in Lay-Down Area . . . . . . . . . . . . . . . . . . . . . . . 55

Figure 6.38 Health Physics Technician Surveying Graphite Prior to Removal . . . . . . . . . 57

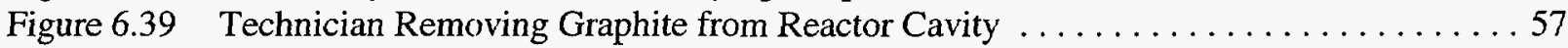

Figure 6.40 Technician Size Reducing a Section of Steel Shell for Packaging $\ldots \ldots \ldots \ldots \ldots 58$

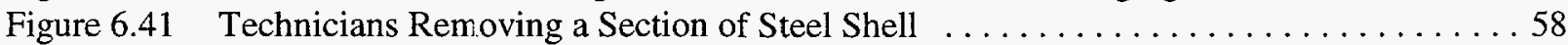

Figure 6.42 Technicians Removing Air System Piping and Shutter Drive Actuator $\ldots \ldots \ldots \ldots 60$

Figure 6.43 Health Physics Technician Surveying Shutter Drive Air Cylinder for

"Free Release" . . . . . . . . . . . . . . . . . . . . . . . . . . . . . . . . . 60

Figure 6.44 High-Dose Shutter Being Removed $\ldots \ldots \ldots \ldots \ldots \ldots \ldots \ldots \ldots \ldots \ldots \ldots \ldots \ldots \ldots$

Figure 6.45 Technicians Removing Lead and Polyethylene Blocks from Inside of a

High-Dose Shutter . . . . . . . . . . . . . . . . . . . . . . . . . . 61

Figure 6.46 Low-Dose Shutters and Pedestals Prior to Removal . . . . . . . . . . . . . . . 62

Figure 6.47 Low-Dose Shutter Being Removed ...................... 62

Figure 6.48 Technician Removing Concrete from South "Wing" Wall with a

$90 \mathrm{lb}(40.82 \mathrm{~kg})$. Jackhammer . . . . . . . . . . . . . . . . . . 64

Figure 6.49 BROKK 150 Removing Reactor Pedestal Concrete . . . . . . . . . . . . . . . 64

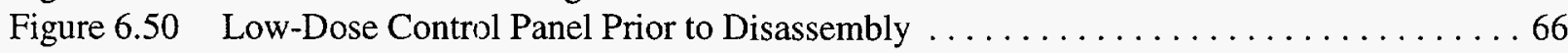

Figure 6.51 Low-Dose Control Panel Partially Disassembled $\ldots \ldots \ldots \ldots \ldots \ldots \ldots \ldots \ldots \ldots$

Figure 6.52 Reactor Control Panel Prior to the Start of Disassembly $\ldots \ldots \ldots \ldots \ldots \ldots \ldots \ldots 6$

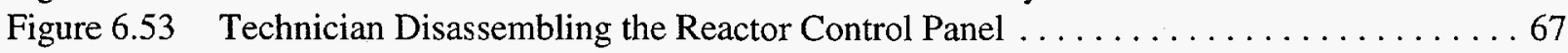

Figure 6.54 Reactor Equipment Room Prior to the Dismantlement of Primary and

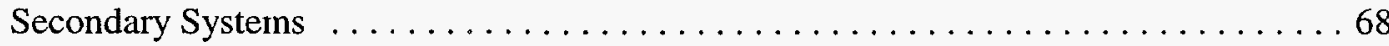

Figure 6.55 Technician Disassembling Systems in the Reactor Equipment Room $\ldots \ldots \ldots 68$

Figure 9.1 Waste Removed from JANUS Reactor Facility $\ldots \ldots \ldots \ldots \ldots \ldots \ldots \ldots \ldots$

Figure 10.1 JANUS D\&D Project Total Cost Breakdown $\ldots \ldots \ldots \ldots \ldots \ldots \ldots \ldots \ldots \ldots$

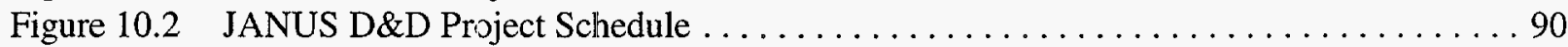

Figure 11.1 Annual Dose Projections for the High-Dose Room $\ldots \ldots \ldots \ldots \ldots \ldots \ldots \ldots \ldots \ldots$

Figure 11.2 Annual Dose Projections for the Reactor Cavity $\ldots \ldots \ldots \ldots \ldots \ldots \ldots \ldots \ldots \ldots . \ldots 9$

Figure 11.3 High Bay Looking East (Room J-105) $\ldots \ldots \ldots \ldots \ldots \ldots \ldots \ldots \ldots \ldots \ldots \ldots$

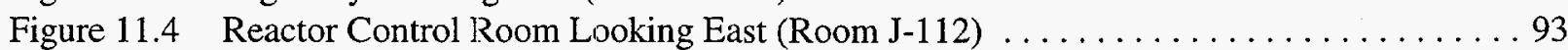

Figure 11.5 Low-Dose Preparation Room Looking East (Room J-014) . . . . . . . . . . . . . . . . 94

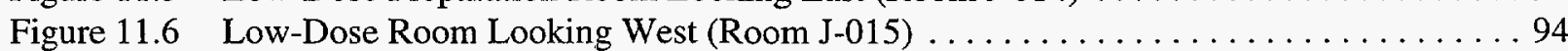

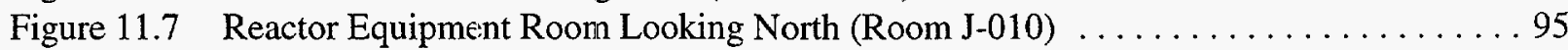

Figure 11.8 High-Dose Preparation Room Looking South (Room J-002) . . . . . . . . . . . . 95

Figure 11.9 Reactor Cavity and High-Dose Room Looking West (Rooms J-200 and J-007) . . . . . 96 


\subsection{EXECUTIVE SUMMARY}

The decontamination and dismantlement of the JANUS Reactor at Argonne National Laboratory-East (ANL-E) was completed in October 1997. Descriptions and evaluations of the activities performed and analyses of the results obtained during the JANUS D\&D Project are provided in this Final Report. The following information is included:

- Objective of the JANUS D\&D Project

- History of the JANUS Reactor facility

- Description of the ANL-E site and the JANUS Reactor facility

- Overview of the D\&D activities performed

- Description of the project planning and engineering

- Description of the D\&D operations

- Summary of the final status of the JANUS Reactor facility based upon the final survey results

- Description of the health and safety aspects of the project, including personnel exposure and OSHA reporting

- Summary of the waste minimization techniques utilized and total waste generated by the project

- Summary of the final cost and schedule for the JANUS D\&D Project

This final report was written in accordance with requirements outlined in the ANL-E D\&D Project Planning Guidance Manual and the ANL-E D\&D Program Management Plan. It covers the entire JANUS D\&D Project, from initiation of planning and characterization activities to final project closeout. The final survey was completed in September 1997, and an IVS was performed in November 1997. After the IVS, the JANUS Reactor facility was released as a "clean" area with two exceptions: The walls and floor of the high-dose room contained activated concrete and some small amount of activated structural steel in the reactor cavity. These areas were isolated to prevent unnecessary entry. Exposure levels in accessible areas, however, were low enough to allow unmonitored access. The JANUS Reactor facility was transferred from the U.S. Department of Energy (DOE) EM-40 roster to ANL-E surplus facilities. 
All accessible areas of the JANUS Reactor facility were decontaminated to meet free-release requirements as specified in the ANL-E Environment, Safety and Health Manual. Contaminated or activated equipment, piping and concrete were removed and packaged for disposal; radiologically clean control panels, equipment, wiring and piping, and radiologically clean lead were removed for recycle or reuse by ANL-E.

Total exposure to project personnel was 0.482 person-rem (4.82 $\mathrm{mSv}$ ) compared to the original ALARA estimate of 2.856 person-rem $(28.56 \mathrm{mSv})$. The total cost of the project was approximately $\$ 2,095,000$ compared to the original estimated cost of $\$ 2,004,745.00$. A total of $4002.1 \mathrm{ft}^{3}$ $\left(113.2 \mathrm{~m}^{3}\right)$ of low-level radioactive waste weighing $343,338 \mathrm{lb}(155,738 \mathrm{~kg})$ was packaged for off-site disposal at a DOE-approved low-level waste repository with a total activity of $3.13 \mathrm{Ci}$ (115.8 GBq). An additional $538 \mathrm{ft}^{3}\left(15.2 \mathrm{~m}^{3}\right)$ of mixed waste weighing 47,024 lb $(21,330 \mathrm{~kg})$ was packaged for treatment/storage.

\section{$2.0 \quad$ PROJECT OBJECTIVE}

The JANUS D\&D Project was directed toward the following goals:

- Removal of radioactive and hazardous materials associated with the JANUS Reactor facility

- Decontamination of the JANUS Reactor facility to unrestricted use levels

- Documentation of all project activities affecting quality (i.e., waste packaging, instrument calibration, audit results, and personnel exposure)

These goals had been set in order to eliminate the radiological and hazardous safety concerns inherent in the JANUS Reactor facility and to allow, upon completion of the project, unescorted and unmonitored access to the area. The reactor, reactor systems and the large quantity of lead shielding were the primary areas of concern, while the remaining neutron-induced activity in the biological shield and neighboring ares.s was of secondary concern. ANL-E health physics technicians characterized the JANUS Reactor facility from January to March 1996 . The characterization identified a total of fifteen radionuclides, with a total activity of less than $28 \mathrm{mCi}(1.04 \mathrm{GBq})$. The primary radionuclides of concern were $\mathrm{Co}^{60}, \mathrm{Eu}^{152}$ and $\mathrm{Eu}^{154}$. Additional radionuclides identified during the $\mathrm{D} \& \mathrm{D}$ of the facility included $\mathrm{Sr}^{90}, \mathrm{Th}^{232}$ and depleted uranium. The highest dose rates observed during the project were associated with the reactor vessel. Radiation levels of $400 \mathrm{mrem} / \mathrm{hr}$ $(4.0 \mathrm{mSv} / \mathrm{hr})$ were measured on the attenuator tank inside the reactor vessel after removal for size reduction and packaging. DCE Order 5480.2A establishes the maximum whole body exposure for occupational workers at $5 \mathrm{rem} / \mathrm{yr}(50 \mathrm{mSv} / \mathrm{yr}$; the administrative limit at ANL-E is $1 \mathrm{rem} / \mathrm{yr}$ (10 $\mathrm{mSv} / \mathrm{yr}$ ). 


\section{JANUS Reactor Facility History}

The JANUS Reactor was built in 1963 as a biological research facility used to study the effects of high and low fluence of neutron radiation on animals. Experiments performed at JANUS were used to determine the whole lifetime "chronic" effects, as well as the "acute" high-dose effects, of neutron exposure. The $200 \mathrm{~kW}$ reactor was a heterogeneous, light-water-moderated, tank-type reactor. There were two faces to the reactor (180 degrees apart) which allowed delivery of neutrons of different intensities to two separate rooms for low-level and high-level irradiations.

The JANUS Reactor facility operated until March 1992. The reactor was defueled in 1993, and the fuel was shipped off-site for storage at another DOE facility. All liquid support systems were drained, and the facility was placed into dry lay-up awaiting D\&D operations. As a result of the facility's operating history, structures and components remained radioactively activated.

\subsection{Site Description}

The JANUS Reactor facility was located in Building 202 on the ANL-E site, a 1,275 acre $\left(5.16 \mathrm{~km}^{2}\right)$ reservation in DuPage County, Illinois operated by the University of Chicago under contract with the U.S. Department of Energy. Approximately 4,000 people work at the ANL site. The majority of the reservation is forested and landscaped with only 200 acres $\left(0.81 \mathrm{~km}^{2}\right)$ currently dedicated to operational facilities. The Laboratory is approximately 22 miles $(35.4 \mathrm{~km})$ southwest of Chicago and 25 miles $(40.3 \mathrm{~km})$ west of Lake Michigan at the closest point. Access is available from State Highway 83, county roads, Northgate Road and Cass Avenue, all of which have access to Interstate 55 (see Figure 3.1). The reservation is surrounded by the 2,040 acre $\left(8.26 \mathrm{~km}^{2}\right)$ Waterfall Glen Forest Preserve, a greenbelt forest preserve managed by the DuPage County Forest Preserve District. The areas south and west of the site are primarily rural, with more heavily populated areas to the north and east. The Des Plaines River, Illinois Waterway and the Chicago Sanitary and Ship Canal are all located about 1 mile $(1.6 \mathrm{~km})$ from the southern boundary of the site.

The majority of the work described in this report was performed in J-Wing of Building 202 (see Figure 3.2). The contractor maintained project offices, crew facilities and equipment storage in temporary offices in H-Wing, located near the JANUS Reactor facility. A D\&D project office staffed by the JANUS field engineer was maintained in J-Wing.

The decontamination and disassembly of this facility was funded by the DOE Office of the Assistant Secretary for Environmental Management, specifically EM-40 (Environmental Restoration), in order to allow its reuse by other DOE programs. 


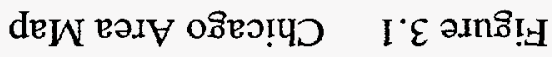

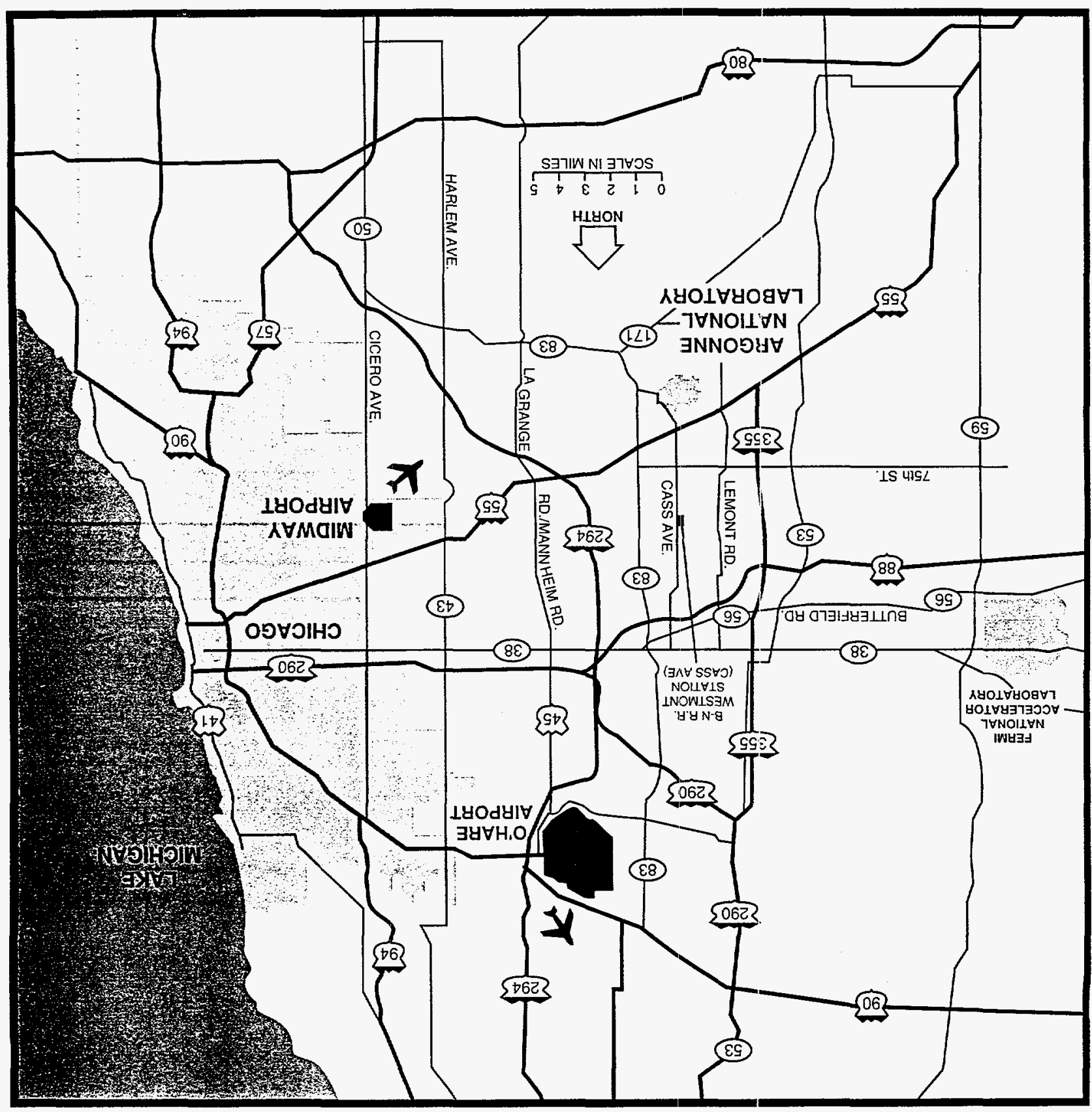

I I fo $\diamond \partial 8 e^{d}$ 


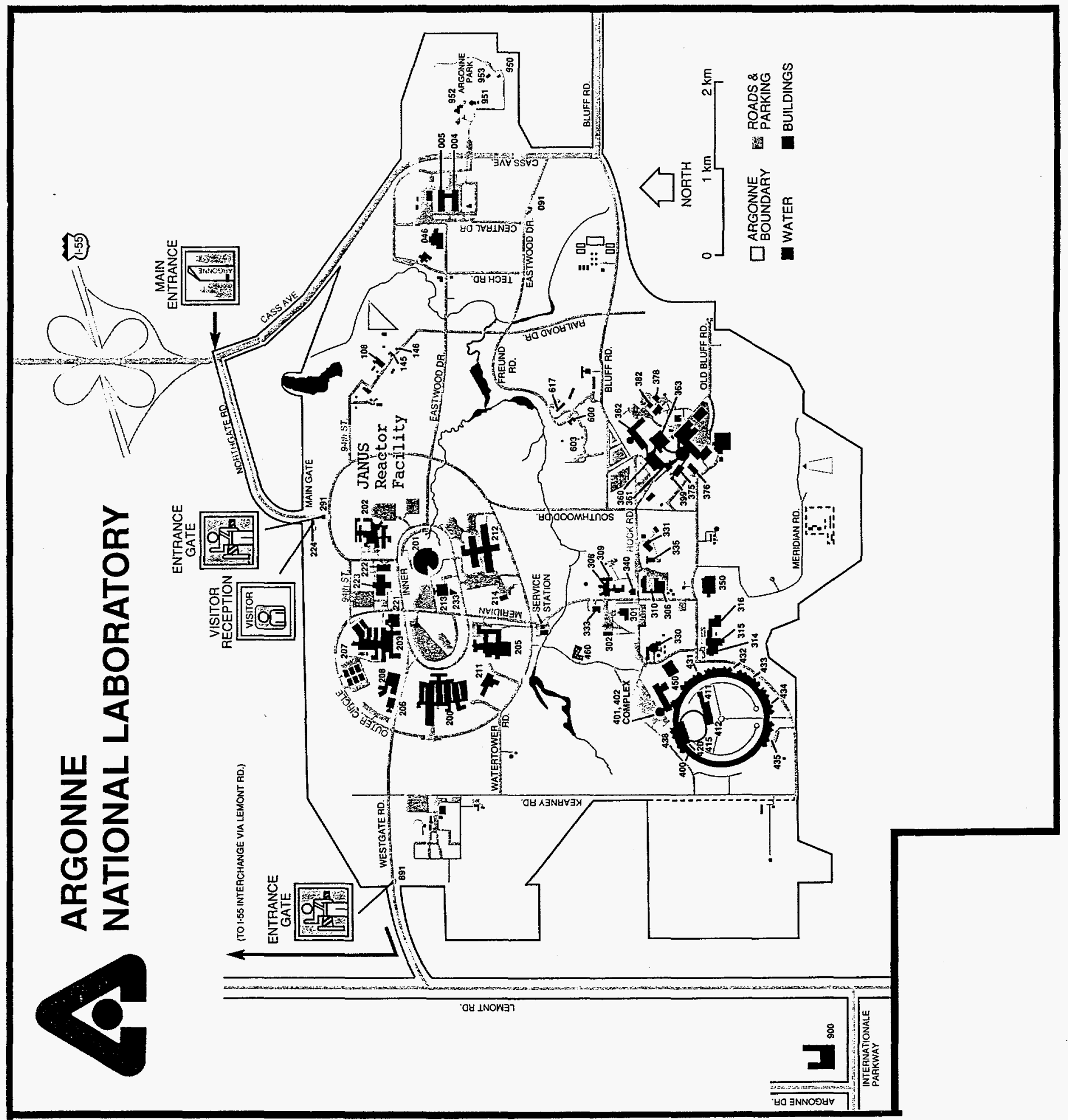

Figure 3.2 ANL-E Site Map 


\subsection{Facility Description}

\subsubsection{General}

The JANUS Reactor facility was located on the east side of Building 202 in the J-Wing. The facility occupied two floors, e.g., the main floor and the service floor.

The main floor comprised the high bay, control room, fan room, and HEPA filter room (see Figures 3.3 and 3.5). The 10 ton (9.1 MT) crane, high-dose room shutter drives and removable floor plugs that provided access to the reactor, high-dose room ceiling and low-dose room were located in the high bay. The operating controls and instrumentation for reactor operation and monitoring were in the control room, and the air supply fans, environmental controls as well as several JANUS electrical distribution panels were in the fan room. The HEPA filter room contained the three HEPA filters, exhaust fan and two air reservoirs and associated piping for the high-dose room shutter control system.

The service floor comprised the low-dose preparation room, low-dose room, high-dose preparation room, high-dose room and the reactor equipment room (see Figures 3.4 and 3.5). The low-dose preparation room contained control panels for the high- and low-dose rooms, the rabbit tube assembly, various electrical distribution panels and the building sump system. The low-dose room provided a space for low-flux experiments, although the area was never utilized for experimental purposes during the operating history of the facility. The high-dose preparation room contained electrical distribution panels, high-dose room door controls and space for experiment preparation. Space was provided in the high-dose room for high-flux experiments, and this area was used extensively throughout the operating history of the JANUS Reactor facility. The reactor equipment room contained the pumps, valves, components and piping for the primary system, secondary system, helium systems, skimmer system and water purification system.

\subsubsection{The Reactor}

Located between the high- and low-dose rooms was the reactor cavity. This area contained a steel shell which housed the graphite reflector and reactor tank. The vertical cylindrical core comprised 19 fuel assemblies, each 26 in $(66 \mathrm{~cm})$ long containing a uranium-aluminum alloy fuel of highly enriched uranium. The core was installed in a $4 \mathrm{ft}(1.22 \mathrm{~m})$ by $7 \mathrm{ft}(2.13 \mathrm{~m})$ tall aluminum reactor tank and was positioned off center inside the tank to provide different neutron intensities in the two dose rooms. The facility was capable of producing neutron doses up to $60 \mathrm{rad}(0.6 \mathrm{~Gy})$ per minute in the high-dose room. 


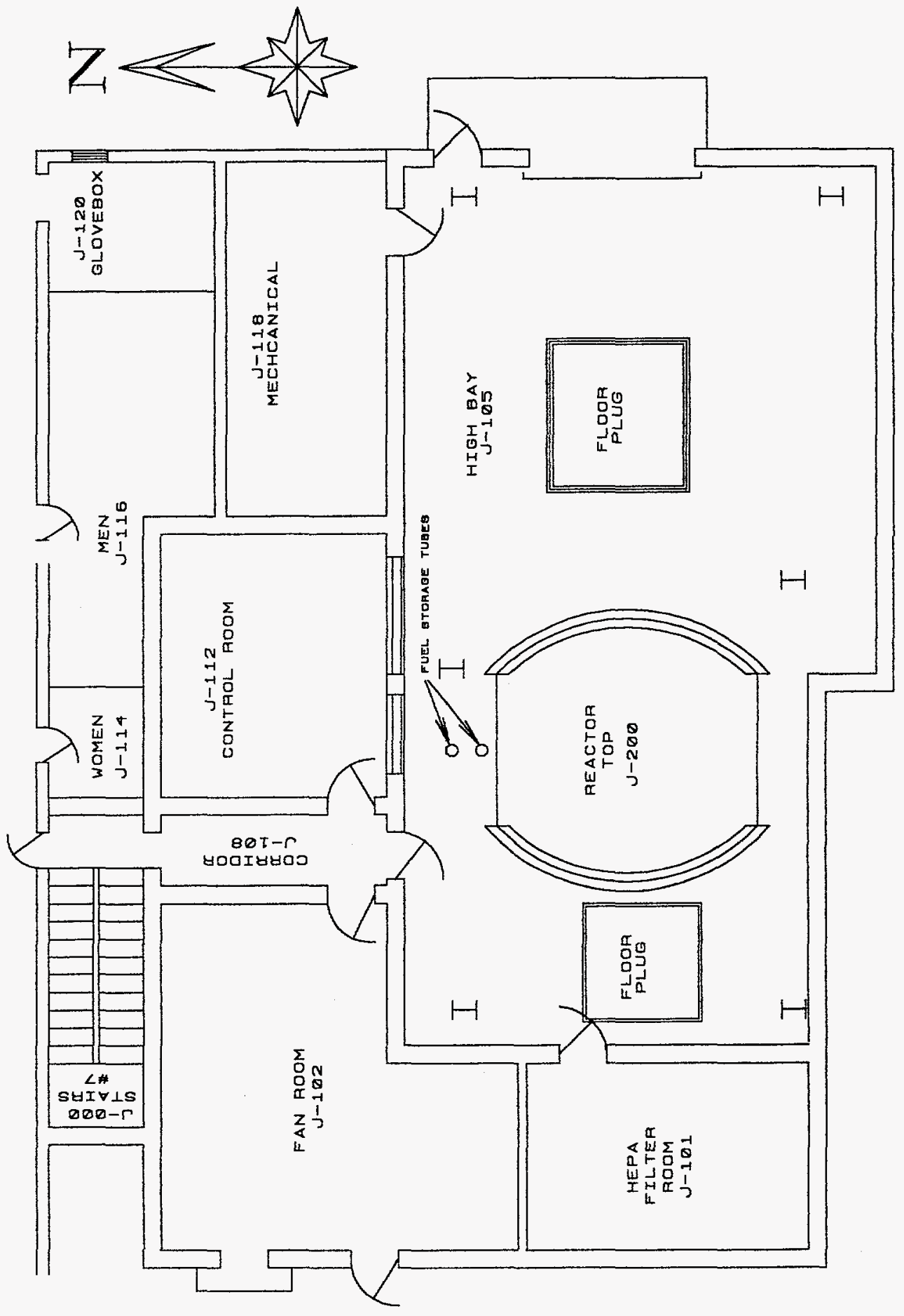

Figure 3.3 JANUS Reactor Facility Main Floor Layout 


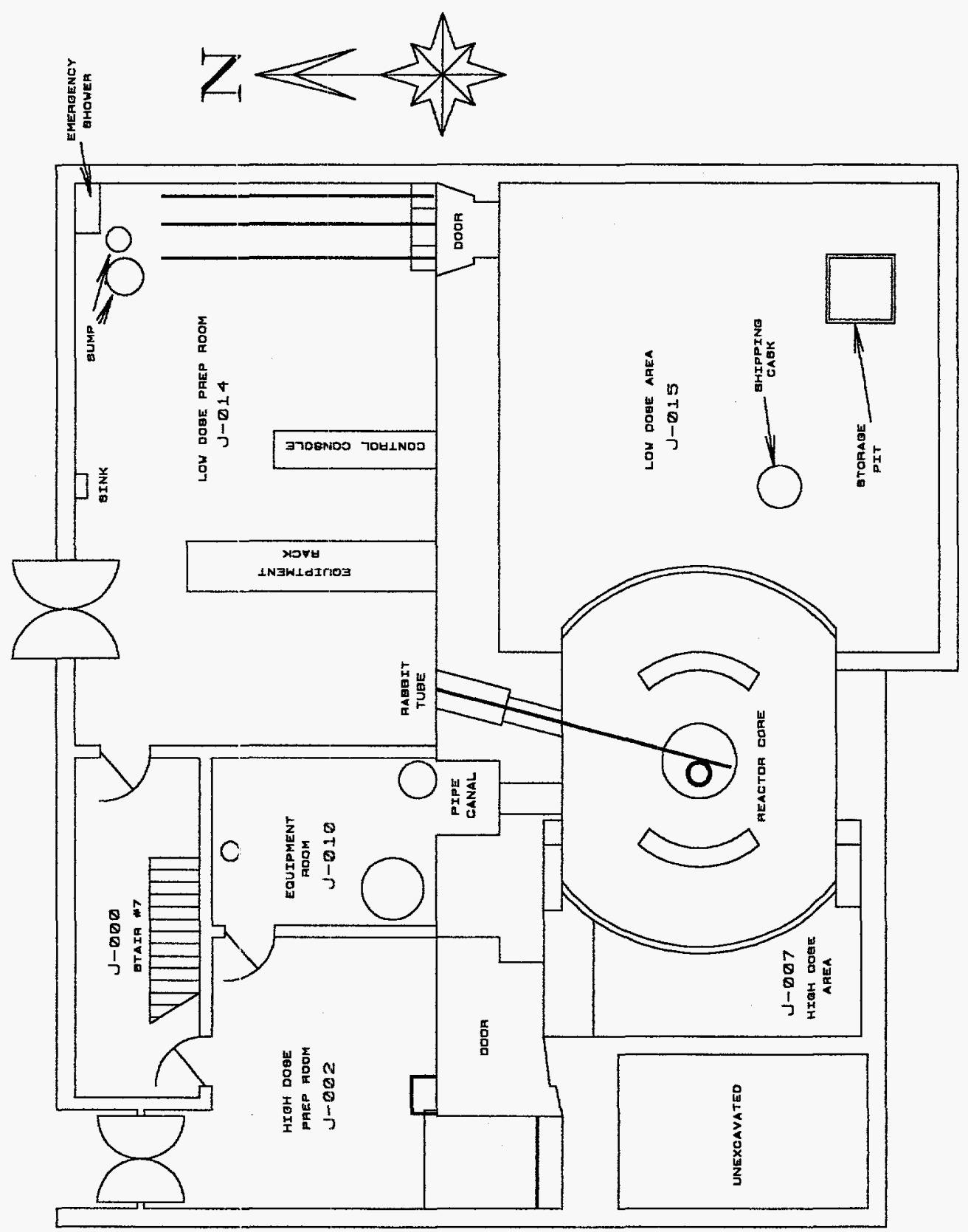

Figure 3.4 JANUS Reactor Facility Service Floor Layout 


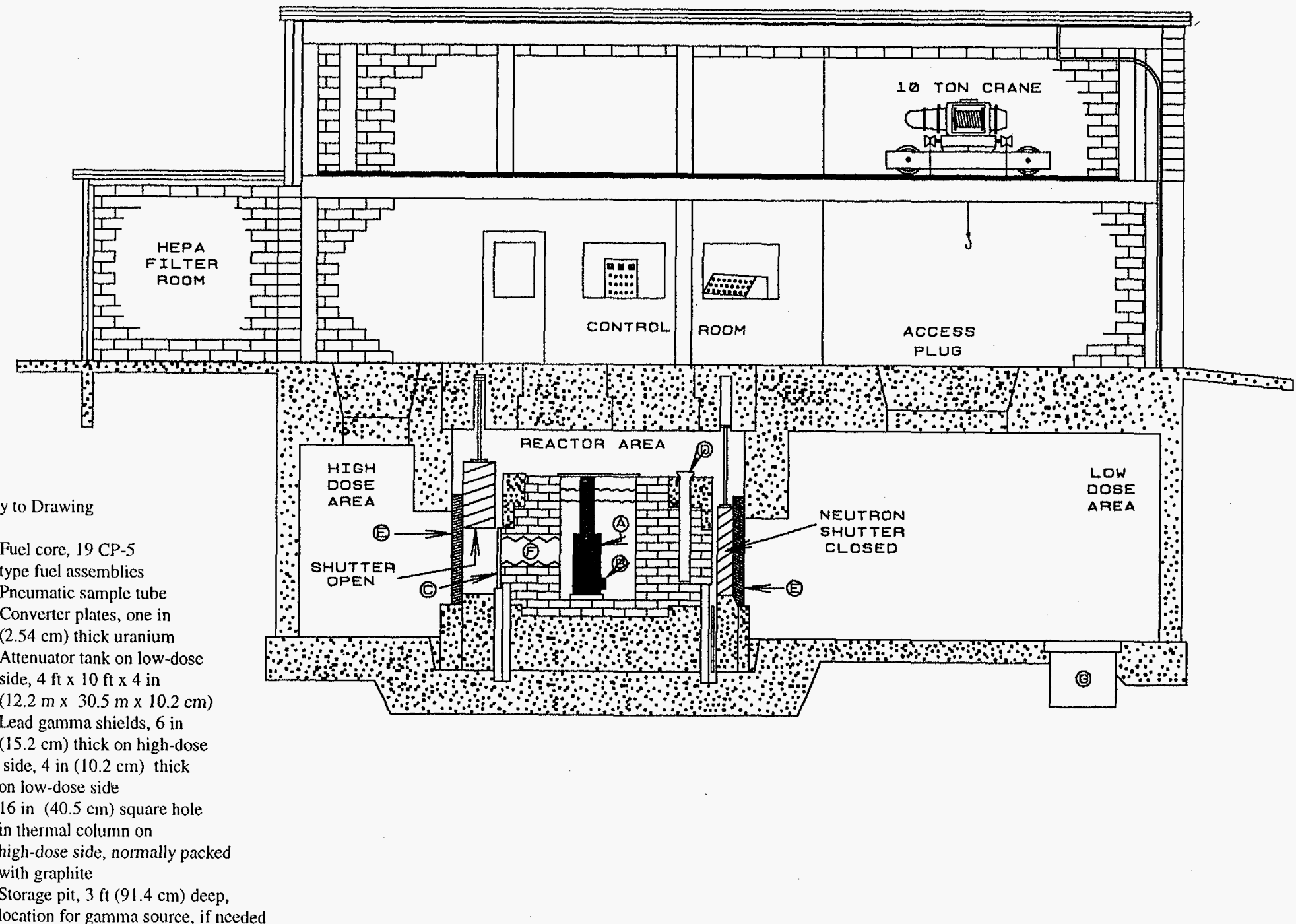




\subsubsection{The High-Dose Room}

The high-dose irradiation room was $12 \mathrm{ft}(3.66 \mathrm{~m})$ long (from the face of the reactor), $16 \mathrm{ft}(4.88 \mathrm{~m})$ wide and $10 \mathrm{ft}(3.05 \mathrm{~m})$ high. Additional gamma (lead) and neutron (borated hardboard) shielding was installed in 1969 , making the room somewhat smaller than originally designed. A convex radiation face, bowing outward into the room, allowed neutrons to escape from the reactor. This opening (face) was $3 \mathrm{ft}(0.91 \mathrm{~m})$ high and $6.5 \mathrm{ft}(1.98 \mathrm{~m})$ wide. The distance from the center of the reactor core to the opening was approximately $5 \mathrm{ft}(1.52 \mathrm{~m})$. The high-dose room could accommodate 300 mice in a single experiment.

\subsubsection{The Low-Dose Room}

On the opposite side of the reactor was the low-dose room which was $23 \mathrm{ft}(6.04 \mathrm{~m})$ long, $23 \mathrm{ft}$ $(6.04 \mathrm{~m})$ wide and $11 \mathrm{ft}(3.35 \mathrm{~m})$ high. The convex radiation opening (face) on the low-dose side was $3 \mathrm{ft}(0.91 \mathrm{~m})$ high and $10.5 \mathrm{ft}(3.20 \mathrm{~m})$ wide. The distance from the center of the reactor core to the opening was approximately $7 \mathrm{ft}(2.13 \mathrm{~m})$.

\subsubsection{Converter Plates}

The production of fast neutrons was achieved through the use of movable converter plates manufactured from highly enriched uranium alloyed with aluminum and encased inside an aluminum shell. The curved converter plates were mounted in vertically movable stainless steel frames located outside the steel shell at the high-and low-dose openings (faces). This location did not affect the operational characteristics of the core. The thermal neutrons that escaped from the reactor interacted with the highly enriched urarium of the converter plates to produce fast neutrons.

\subsubsection{Neutron and Gamma Shields}

When personnel were present in the high- and/or low-dose rooms during reactor operations, vertically movable neutron shutters (three-section neutron absorbers) were positioned over each face. The shutters were located between the converter plates and the interior of the high- and low-dose rooms. The high-dose shutters were constructed of lead and borated polyethylene encased inside a steel jacket, while the low-dose shutters were constructed of ferrophosphate concrete in a steel jacket. The shutters were moved up and down by pneumatic cylinders that were operated from the control room.

Since the purpose of the experimental work at the JANUS Reactor facility was to determine the effect of neutron exposure on animals, it was necessary to install gamma (lead) shielding at the faces of the high- and low-dose rooms. In 1969, an additional 4 in $(10.16 \mathrm{~cm})$ of lead shielding was installed in the high-dose roorn to block gamma rays being emitted from concrete activation products in the walls, floor and ceiling; 4 in $(10.16 \mathrm{~cm})$ of borated wall board was also installed to prevent further activation of these concrete structures. 
Vertically movable neutron attenuators constructed of boral were provided for the high- and low-dose openings (faces) of the reactor. These attenuators were positioned in front of the converter plates and moved into position to absorb neutrons whenever personnel were present in the high- or low-dose rooms during reactor operations.

\subsubsection{Rabbit Tube}

A pneumatic rabbit tube penetrated the graphite reflector and the reactor vessel from the north. This shielded tube allowed special in-core irradiations of samples as well as providing for the insertion of the beryllium/antimony start-up source. Samples were pneumatically transferred into the reactor core from a sample loading and unloading station located in the low-dose preparation room.

\subsubsection{Primary Cooling System}

Reactor-produced heat was transferred to the primary water in the reactor tank. This water was circulated from the reactor to the twin main heat exchangers by two $1.5 \mathrm{HP}(1.1 \mathrm{~kW})$ stainless steel centrifugal reactor coolant pumps. The heat exchangers were a single tube sheet design with a fourpass cooling water circuit. They were constructed from stainless steel and normally operated in parallel. When JANUS was operating at full power $(200 \mathrm{~kW})$, primary coolant was circulated at approximately 100 g.p.m. (379 l.p.m.). Normal operating configuration was one pump operating and the second pump in standby. The twin main heat exchangers were constructed from stainless steel and normally operated in parallel. The heat exchangers were a single tube sheet design with a fourpass cooling water circuit. A primary coolant screen assembly was installed directly above the heat exchangers to strain out any foreign objects inadvertently introduced into the core. A $750 \mathrm{gal}$ $(2,839$ l) aluminum primary coolant storage tank was located in the reactor equipment room which could store all or any part of the primary coolant.

\subsubsection{Secondary Cooling System}

The secondary cooling system removed heat from the reactor through the twin heat exchangers on the primary cooling system. Heat removed from the primary coolant was transferred to the cooling tower and dissipated to the surrounding air. The secondary cooling system utilized two $5 \mathrm{HP}$ $(3.7 \mathrm{~kW})$ secondary coolant pumps with a capacity of 250 g.p.m. (946 l.p.m.) each. Typical operation was to run one pump with the second pump in standby.

\subsubsection{Primary Coolant Purification System}

The primary coolant purification system cleansed the coolant by removing soluble ions and insoluble corrosion products in a mixed-bed ion-exchange resin column and protective filters. Primary coolant was side-streamed through the $0.5 \mathrm{ft}^{3}\left(0.014 \mathrm{~m}^{3}\right)$ resin column at $4-5$ g.p.m. (15-19 1.p.m.) and returned to the suction side of the reactor coolant pumps. 


\subsubsection{Skimmer and Level-Control System}

The skimmer and level-control systern was installed to remove the surface film or scum (aluminum oxide) that typically forms on the surface of coolant in reactors of this design. Surface scum has been associated with shortened life cycle for control and safety rods. An eductor was utilized to remove the surface of the primary coolant and direct it to a filter unit where the aluminum oxide was removed from the coolant. After filtration, the water-gas mixture was discharged to the reactor coolant storage tank, and an equal amount of replacement coolant was directed to the suction side of the reactor coolant pumps to maintain a constant level in the reactor tank.

\subsubsection{Helium Systems}

The JANUS Reactor had two helium systems, a reactor helium system and a graphite helium system. The reactor helium system provided an inert atmosphere over the primary coolant in the reactor tank and reactor coolant storage tank. Helium was continuously circulated at 2-3 in of water pressure $(0.372-0.558 \mathrm{~cm} \mathrm{Hg})$ across free surfaces to remove any dissociation products of gas that are produced by the radiation coming from the reactor. This prevented the build-up of an explosive atmosphere.

The graphite helium system supplied an inert atmosphere to the graphite region of the reactor at a continuous flow of $10-12$ in of water pressure $(1.858-2.230 \mathrm{~cm} \mathrm{Hg})$.

\subsubsection{Graphite System}

The principal graphite system was contained between the reactor tank and steel shell, with the graphite being used as a neutron reflector and thermalizer. Also, the base of the reactor tank sat upon a layer of graphite. It had been installed in offset interlocking blocks that completely surrounded the reactor on all sides and the bottom.

\subsection{OVERVIEW OF THE JANUS D\&D PROJECT}

\subsection{General}

The JANUS D\&D Project began in October 1995 when funding was approved for characterization, document preparation and environmental assessment. This scope of work consisted of preparation of internal documents, e.g., Characterization Plan, Project Management Plan, Quality Assurance Plan, Auditable Safety Analysis, Environmental Assessment, Illinois Environmental Protection Agency (IEPA) Air Quality Permit, Waste Management Plan and appropriate procurement documents. This scope of work was performed from October 1995 through September 1996. From January through March 1996, a characterization of the JANUS Reactor facility was performed and a report prepared by the ANL-E Environment, Safety and Health Physics (ESH/HP) group. In September 1996, a Request for Proposal (RFP) was issued to qualified vendors for the D\&D of the 
JANUS Reactor Facility. In December 1996, a contract was awarded to Afftrex Ltd. of Pittsburgh, Pennsylvania to perform the work. On-site mobilization was performed in January 1997, and facility D\&D was completed in September 1997. The final survey was completed in September 1997.

\subsection{Major Tasks}

The following major tasks were performed during the D\&D of the JANUS Reactor facility. Each of these is described in detail in Section 6.0.

Removal of Miscellaneous Components

Electrical System Isolation

Asbestos Abatement

Remove the $75 \mathrm{ft}$ ( $22.86 \mathrm{~m}$ ) Exhaust Stack

Remove the Cooling Tower

Remove the Glovebox and Associated HEPA and Duct

Remove Lead-Based Paint from Floor Plugs

Remove Fuel Transfer Cask

Remove Surplus Lead Bricks

Performance of Routine Surveillance and Maintenance Tasks

Demolition of the High Dose-Room

Remove Loose Lead from the Room

Remove Lead from the Walls and Floor

Remove Borated Hardboard

Remove Attenuator Lead

Remove Lead Ceiling

Remove Ceiling Equipment and Concrete

Removal of Reactor

Remove Floor Plugs

Install Containment

Remove Equipment on Top of Reactor

Remove Rabbit Tube

Remove Reactor Shield Plug

Remove Reactor Internals

Remove Reactor Tank

Remove Reactor Area Top Shielding

Remove Graphite Reflector

Remove Steel Shell and Lining 
Removal of Shutter Systems

Remove High- and Low-Dose Shutter Drives

Remove High- and Low-Dose Shutters

Remove Shutter Pedestals

Removal of Structures

Remove Activated Concrete

Remove Low-Dose Room Lead Wall Pedestal

Remove Converter Plate Frames

Remove Concrete: Reactor Pedestal

Removal of Control Room Facilities

Remove High- and Low-Dose Control Consoles

Remove Reactor Control Panels

Remove Experimental Equipment

Removal of Support Sy'stems

Remove Secondary Water System

Remove Primary Water System

Remove Skimmer and Level Control System

Remove Helium Systems

Area Decontamination

Decontaminate Storage Tubes

Perform General Area Clean-up/Decontamination

Project Closeout Activities

Perform Final Surveys and Sampling

Seal Pipe Canal

Close and Cap Storage Tubes

Demobilize Site

Prepare and Submit Final Report 


\subsection{JANUS D\&D PROJECT PLANNING AND ENGINEERING}

\subsection{Project Organization}

The JANUS D\&D Project had a specific management structure in which the administrative, programmatic and technical responsibilities, including management controls and reporting systems for the performance of the project, were well defined. The various organizations involved in this project and their responsibilities are described below. A project responsibility chart is provided in Figure 5.1.

\subsubsection{United States Department of Energy}

Overall responsibility for accomplishment of the JANUS Reactor facility D\&D project resided with the Secretary of Energy. Responsibility flowed from the Secretary through the Office of the Assistant Secretary for Environmental Management (DOE-EM) to DOE Chicago Operations (DOE-CH) and to the DOE Argonne Group (DOE-ARG).

\subsubsection{Argonne National Laboratory-East}

The Decontamination and Decommissioning Program of the Technology Development Division (TD) Waste Management Program was assigned the lead for the D\&D of the JANUS Reactor facility, which included direction, management and control of all phases of work. A project manager was assigned and given full line authority and responsibility for the hands-on management of the project. The project manager was responsible for the consistent application of project controls, developed through a risk assessment, to ensure acceptable performance and successful completion of the JANUS Reactor facility D\&D.

\subsubsection{D\&D Field Work}

A contract to perform D\&D field work was awarded to Afftrex, Ltd. To accomplish their assigned scope of work, they provided D\&D technicians, DOE-certified health physics technicians, health and safety oversight personnel and management personnel. To fulfill contract requirements, they provided to the ANL-E project manager a project-specific Environment, Safety and Health Plan and monthly reports which detailed the work accomplished, cost of work performed and issues or concerns regarding the project. 


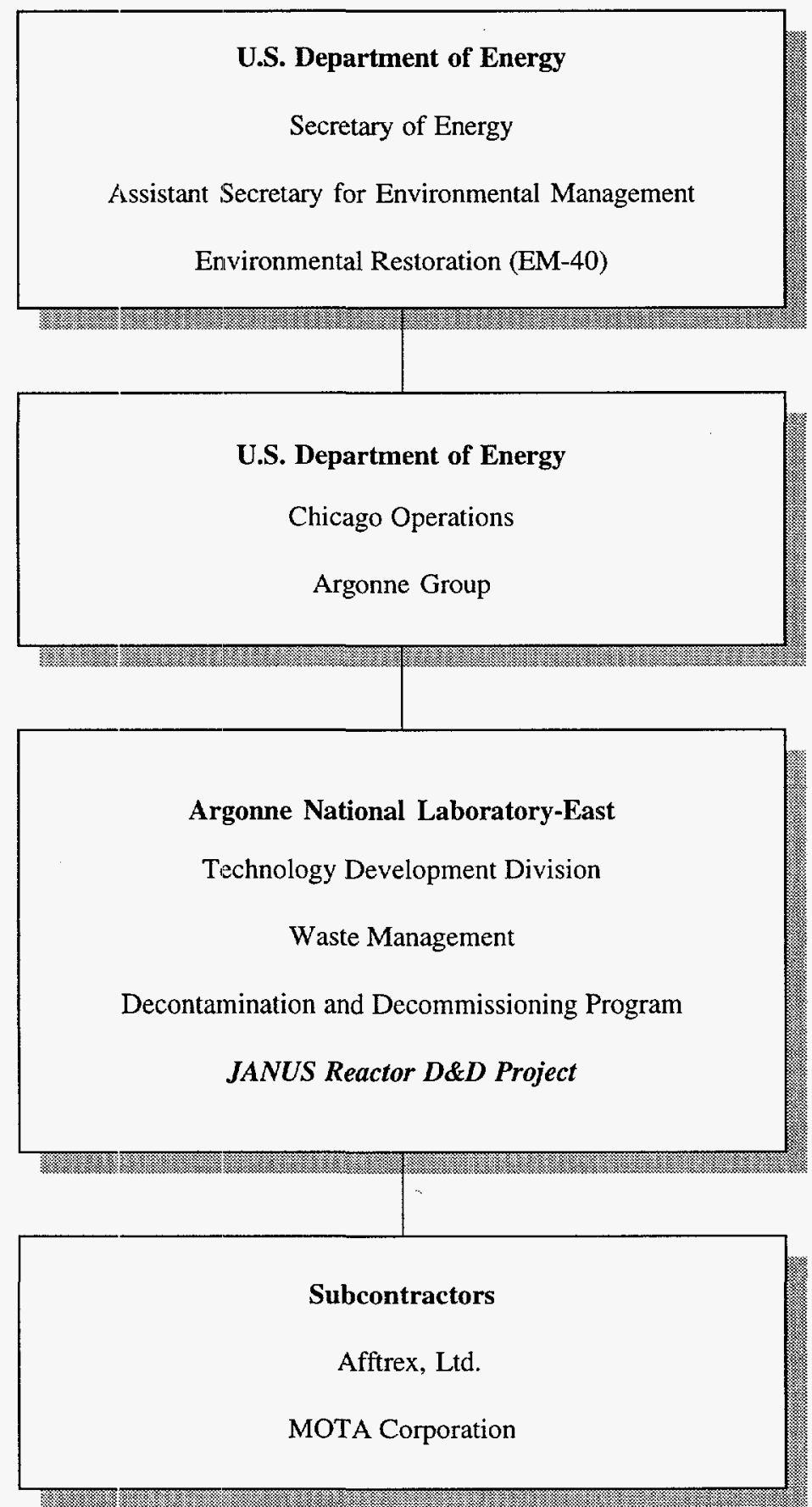

Figure 5.1 JANUS D\&D Project Responsibility Chart 


\subsubsection{Project Oversight}

Project oversight was provided by personnel from various ANL-E organizations, e.g., Environment, Safety and Health (ESH), Plant Facilities and Services (PFS), and the Technology Development Division (TD). In addition, a contract was awarded to MOTA Corporation (Cayce, South Carolina) for an experienced field engineer to oversee the project's day-to-day activities. The field engineer's responsibilities included review and approval of project plans and procedures, and monitoring worksite activities to identify and evaluate conditions which could affect the health and safety of workers, laboratory personnel, the general public or the environment.

\subsubsection{Organizational Relationships}

Figure 5.2 shows the organizational relationship of the JANUS D\&D Project to ANL-E and to the laboratory support services. Figure 5.3 shows the organizational relationship between the ANL-E D\&D Program and the subcontractors. The ANL-E project manager had full responsibility for all subcontracting activities.

\subsection{Project Engineering}

\subsubsection{Quality Assurance}

The project Quality Assurance (QA) Plan prescribed the requirements for achieving a satisfactory level of quality in the performance of project activities. These requirements were based upon existing codes, standards and practices found in the current issues of ANSI/ASME NQA-1, DOE Order 5700.6C, the ANL-E QA Implementation Guide and the ANL-E QA Planning Guide. The following project D\&D activities were covered by the project QA Plan:

- Segregating of radioactive and nonradioactive waste

- $\quad$ Packaging of radioactive, hazardous and mixed waste

- Determining curie and radionuclide content of waste packages

- Calibrating instruments to NIST traceable standards

- Inspecting and certifying lifting equipment

- Inspecting waste packages

- Maintaining sample chain-of-custody compliance

- $\quad$ Auditing of the QA Plan

QA responsibilities for all project management personnel were defined by the project QA Plan. The Project manager was assigned overall responsibility for the execution of the project QA Plan. Assistance in carrying out specific QA requirements was provided by the Quality Assurance Representatives (QARs) from TD, ESH and the Environmental Management Operations (EMO) divisions, and by personnel from the ESH and EMO divisions. The Office of ESH/QA Oversight provided an audit and verification function. Specific requirements carried out by each office are discussed below. 


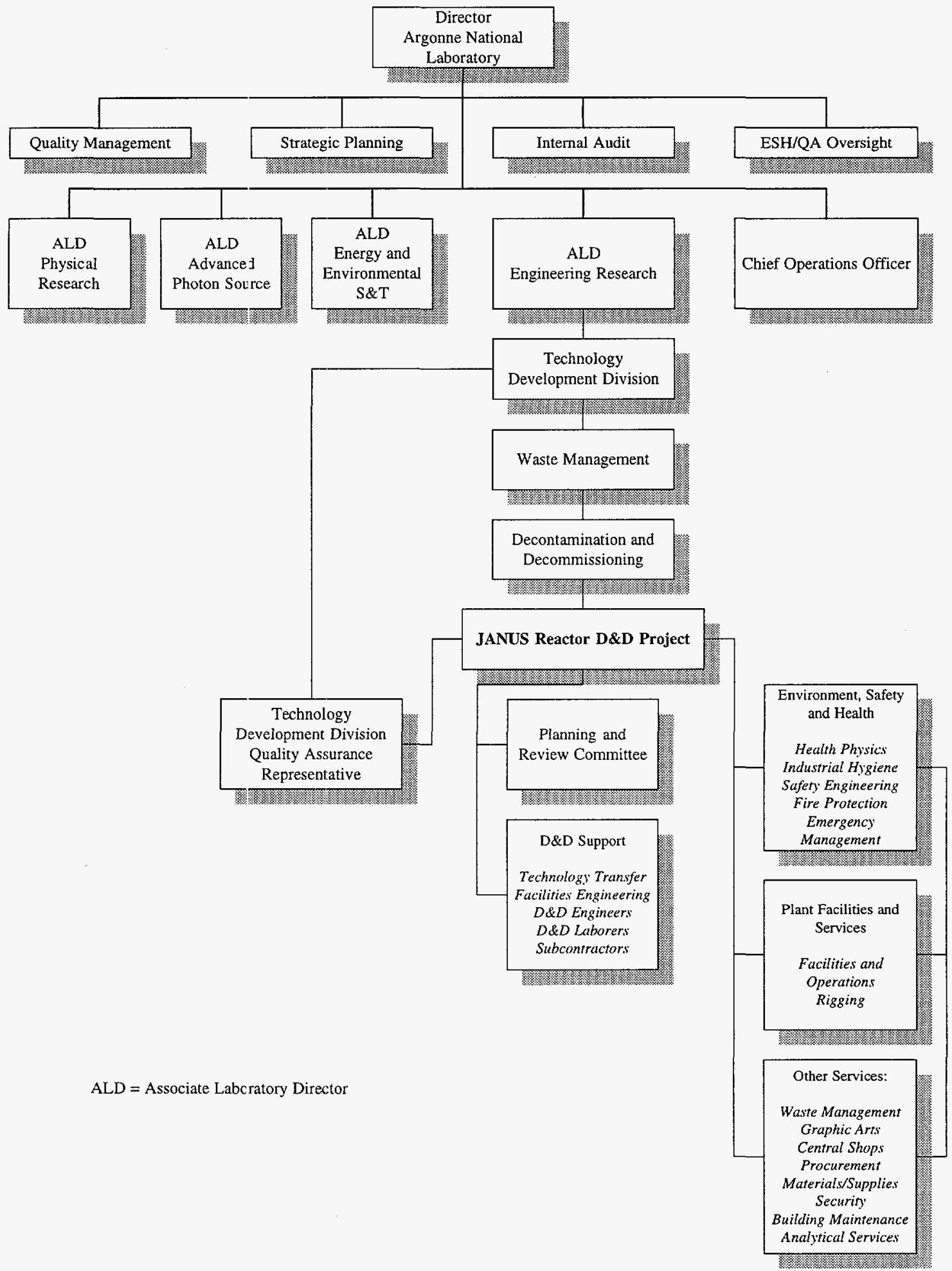

Figure 5.2 Relationship of JANUS D\&D Project to Argonne National Laboratory-East 


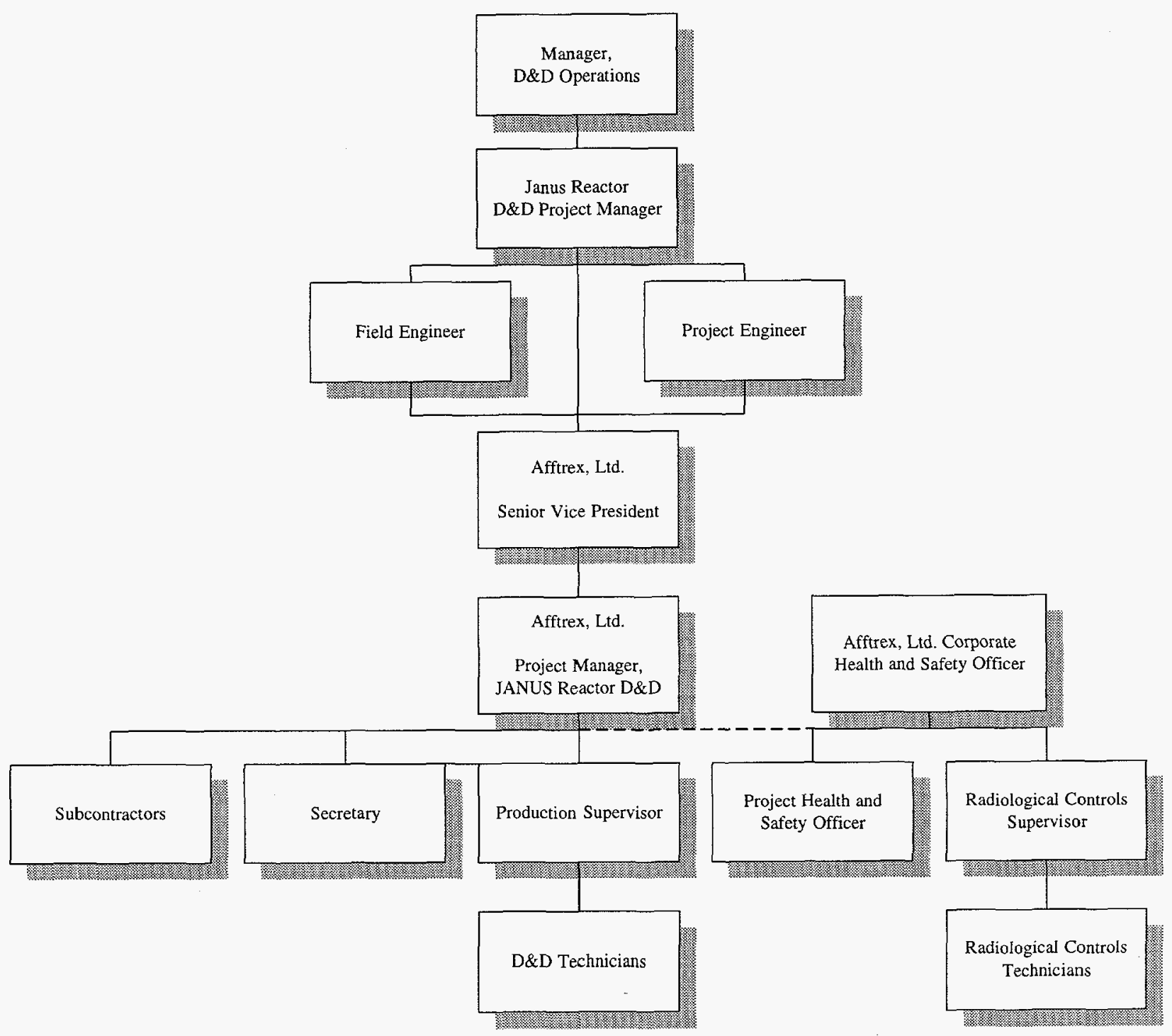

Figure 5.3 Relationship of JANUS D\&D Project to Subcontractors 
The ESH/Health Physics Manager was responsible for oversight of the sampling, sample analysis, standards, instrument calibration, radiation safety, radiation monitoring and final radiation survey of the facility conducted by the D\&D subcontractor.

The ESH Manager was responsible for providing project oversight of subcontractor safety and health practices during performance of the D\&D field work and for reviewing and approving the subcontractor's plans and procedures to ensure compliance with federal, state and laboratory rules and regulations.

The Waste Management Operations (WMO) Manager was responsible for providing training and oversight of the subcontractor's waste packaging activities and for providing disposal of the radioactive waste generated during project $\mathrm{D} \& \mathrm{D}$ activities.

The QARs for EMO, ESH and TD had joint responsibility for review and approval of the project QA Plan. They assisted the Project manager in implementing the QA Plan and served as an interface with the Office of Environment, Safety and Health/Quality Assurance (ESH/QA) Oversight.

ESH/QA Oversight was responsible for auditing the project to verify compliance with the QA Plan and to determine the Plan's effectiveness. The Office reviewed the QA Plan prior to issuance and provided guidance and consultation to Divisional QARs. It also served as third party independent review of all project QA-related issues.

\subsubsection{Project Control}

The JANUS D\&D Project manager had prime control and overall responsibility for the project. Details of project activities were documented on daily project log sheets. In addition, progress was reported to DOE through weekly and monthly progress reports. All reports and records were reviewed by the Project manager to identify any deficiencies. Weekly meetings were held with project personnel to discuss work performed and the upcoming work schedule, and to identify any issues or problems. Periodic project status review meetings were held with TD management and with DOE representatives.

\subsubsection{Project Data}

Data generated by D\&D activities, e.g., survey results, instrument calibrations, sample analyses, personnel radiation and toxic material exposures, have been retained as a permanent record of the project. ANL-E management staff reviewed the data to assure that all operations were in compliance with QA Plan specifications. Periodic QA audits of the data were performed to verify accuracy and compliance. 


\subsubsection{Training}

All project personnel involved with the JANUS D\&D Project were required by ANL-E policy to meet minimum training requirements, as identified below:

For all personnel requiring unescorted access to the JANUS Reactor facility:

- $\quad$ ANL-E Contractor Safety Orientation

- $\quad$ ANL-E Radiological Worker II

- $\quad$ OSHA 40-hour Hazardous Waste Site Operations

- $\quad$ Building 202 and JANUS Facility Orientation

- $\quad$ Conduct of Operations Training

- $\quad$ ANL-E Quality Assurance Plan Training

For personnel assigned as Health and Safety Manager:

- OSHA Hazard Recognition for Construction

For personnel who perform health physics-related functions:

- Previously qualified as a Radiological Controls Technician at a DOE site

For personnel who performed radioactive waste packaging, inspection or labeling functions:

- $\quad$ Complete ANL-E Radioactive Waste Generator Training

For personnel who operated fork lifts and/or the 10-ton (9.1 MT) crane:

- $\quad$ ANL-E ESH approved fork lift operation training

- $\quad$ ANL-E ESH approved crane operation training and provide documentation of previous crane operating experience

Additional job-specific training requirements for individuals involved in those operations:

- $\quad$ Lead hazards training

- Working near asbestos training

- Confined space training

- Specialized training for various equipment and tools 


\subsubsection{Health and Safety}

The Project manager was responsible for implementing the ANL-E Health and Safety requirements for the project to ensure compliance with existing directives on environment, safety and health issues. The actions implemented are discussed below.

\subsubsection{Environment, Safety and Health Policy}

All project activities were performed in a manner which ensured protection of the environment and the health and safety of the general public and workers. All project personnel had the authority and responsibility to stop work if an unsafe condition or activity was observed. The Project manager was the only individual at the project level with authority to restart work after an unsafe condition or activity had been identified and corrected. All work was performed in accordance with the ANL-E ESH Manual, the JANUS D\&D Auditable Safety Analysis and the project-specific Environment, Safety and Health Plan prepared by Afftrex.

\subsubsection{Planning and Review}

A Planning and Review Cornmittee consisting of technical, operating and safety personnel was appointed by the Project manager in order to provide a mechanism for independent review of the plans and procedures utilized in the D\&D effort. This committee reviewed proposed plans and procedures and resolved differences that arose regarding methods of operation. It also served as an internal safety evaluation committee which made recommendations to the JANUS D\&D Project manager. The JANUS D\&D Project manager held final approval authority for all plans and procedures.

\subsubsection{Radiation Safety}

Radiation safety at the JANUS D\&D Project was the responsibility of Afftrex health physics personnel. The ANL-E ESH Manual and the Afftrex JANUS D\&D project-specific Radiological Controls Plan served as guides for implementing the project's radiation safety program. Approximately 400 hours of health physics oversight of the project was provided by ANL-E ESH/HP personnel. This included review of subcontractor health physics plans and procedures, audits of project data (i.e., surveys, Radiological Work Permits (RWPs) and personnel exposure reports), and performance of periodic radiological surveys of areas and materials to verify subcontractor survey results. All project plans and procedures were developed and implemented using the "As Low As Reasonably Achievable" (ALARA) principle. 


\subsubsection{Industrial Hygiene}

Afftrex held responsibility for planning, implementing and sampling hazardous substances at the project site in accordance with OSHA and ANL-E regulations. ANL-E ESH Industrial Hygiene (IH) furnished technical guidance on toxic materials handling (lead, asbestos, mercury and cadmium) and reviewed sample results obtained by the Afftrex to ensure compliance with ANL-E and OSHA requirements.

\subsubsection{Industrial Safety}

Afftrex held responsibility for all industrial safety aspects of the project and was required to comply with rules and regulations as stated by OSHA and in the ANL-E ESH Manual and the projectspecific Environment, Safety and Health Plan prepared by Afftrex. ANL-E ESH safety engineering personnel and the Project manager and staff continuously observed subcontractor operations. The project Surveillance and Maintenance Plan required weekly safety inspections and comprehensive monthly safety inspections performed by project management, safety engineering and the subcontractor to identify existing or potential safety hazards. Daily project meetings, weekly toolbox meetings and monthly safety meetings were used to keep project personnel aware of potential or existing personnel hazards and accident prevention techniques.

\subsubsection{Fire Protection and Security}

Project fire protection services and safety guidance were provided by the ANL-E Fire Department. Fire Marshals made periodic tours of the work site to assess fire potential and fire protection, and to advise project management on potential fire safety improvements. Physical security was provided by the ANL-E security force.

\subsection{Conduct of Operations}

The JANUS D\&D Project was performed in accordance with guidelines established in the ANL-E D\&D Conduct of Operations Manual. The eight elements utilized by the project are:

- Operations organization and administration

- Communications

- Investigation of abnormal event(s)

- Control of systems and equipment status

- Log-keeping

- Postings

- Labeling

- Operations essential to ensure safe and timely progress the $D \& D$ project 


\subsection{Site Characterization}

During January and February 1996, ANL-E Health Physics (ESH/HP) Group performed a detailed characterization of the JANUS Reactor Facility. The characterization revealed the presence of fifteen different radionuclides, twenty areas with asbestos and seven objects coated with lead-based paint. In addition to what was found during the characterization, additional radionuclides, hazardous materials and mixed waste were identified during the performance of D\&D operations.

\subsubsection{Radiological Contaminants}

Table 5.1 identifies nuclides found during the characterization and performance of D\&D operations at the JANUS Reactor facility.

\subsubsection{Hazardous Materials}

Table 5.2 identifies the types and locations of hazardous materials found during the characterization and performance of D\&D operations.

\subsubsection{Mixed Waste}

Table 5.3 identifies the types and locations of mixed waste found during the characterization and performance of $\mathrm{D} \& \mathrm{D}$ operations.

\subsection{Alternatives Assessment}

After shutdown of the JANUS Reactor facility in 1992, a facility options review was conducted by DOE. The extremely high upgrade cost of bringing the JANUS Reactor facility up to current code and safety requirements, as well as a decreased interest in research directed toward the effects of neutron radiation on animals, resulted in a determination to declare the facility surplus to DOE's needs. In 1993, the facility was placed on the DOE EM-40 D\&D roster. 
Table 5.1 Nuclides Found During Characterization and Performance of D\&D Operations

\begin{tabular}{|c|c|c|c|}
\hline Isotope & $\begin{array}{c}\text { Maximum } \\
\text { Concentration } \\
\end{array}$ & Area Found & Remarks \\
\hline $\mathrm{Co}^{60}$ & $\begin{array}{l}97,400 \mathrm{pCi} / \mathrm{g} \\
(2632.43 \mathrm{~Bq} / \mathrm{g})\end{array}$ & $\begin{array}{l}\text { Primary piping, concrete, steel, instrument } \\
\text { packages, graphite and aluminum reactor tank }\end{array}$ & $\begin{array}{l}\text { Predominant } \\
\text { nuclide }\end{array}$ \\
\hline $\mathrm{Eu}^{152}$ & $\begin{array}{l}3,100 \mathrm{pCi} / \mathrm{g} \\
(114.81 \mathrm{~Bq} / \mathrm{g})\end{array}$ & Graphite, rabbit tube smear and concrete & $\begin{array}{l}\text { Predominant } \\
\text { nuclide }\end{array}$ \\
\hline $\mathrm{Eu}^{154}$ & $\begin{array}{l}266 \mathrm{pCi} / \mathrm{g} \\
(9.85 \mathrm{~Bq} / \mathrm{g})\end{array}$ & Graphite, rabbit tube smear and concrete & $\begin{array}{l}\text { Predominant } \\
\text { nuclide }\end{array}$ \\
\hline $\mathrm{U}^{\mathrm{NAT}}$ & $\begin{array}{l}99 \mathrm{dpm} / 100 \mathrm{~cm}^{2} \\
\left(1.65 \mathrm{~Bq} / 100 \mathrm{~cm}^{2}\right)\end{array}$ & Spot on floor in low-dose room & $\begin{array}{l}\text { Fixed } \\
\text { contamination }\end{array}$ \\
\hline $\mathrm{Th}^{\mathrm{NAT}}$ & $\begin{array}{l}99 \mathrm{dpm} / 100 \mathrm{~cm}^{2} \\
\left(1.65 \mathrm{~Bq} / 100 \mathrm{~cm}^{2}\right)\end{array}$ & Spot on floor in low-dose room & $\begin{array}{l}\text { Fixed } \\
\text { contamination }\end{array}$ \\
\hline $\mathrm{Rn}^{222}$ & not available & Pre-filters in pump room & Natural source \\
\hline $\mathrm{Rn}^{220}$ & not available & Pre-filters in pump room & Natural source \\
\hline $\mathrm{Pu}^{238}$ & $\begin{array}{l}0.15 \mathrm{pCi} / \mathrm{g} \\
(5.55 \mathrm{mBq} / \mathrm{g})\end{array}$ & Inside glove box & Trace amount \\
\hline $\mathrm{Pu}^{239 / 240}$ & $\begin{array}{l}2.0 \mathrm{pCi} / 100 \mathrm{~cm}^{2} \\
\left(74 \mathrm{mBq} / 100 \mathrm{~cm}^{2}\right)\end{array}$ & Inside glove box and upper rabbit tube & Trace amount \\
\hline $\mathrm{Ra}^{226}$ & $\begin{array}{l}4.03 \mathrm{pCi} / \mathrm{g} \\
(149.11 \mathrm{mBq} / \mathrm{g})\end{array}$ & Concrete, lead, thimble hole & Natural source \\
\hline $\mathrm{Zn}{ }^{65}$ & $\begin{array}{l}3,600 \mathrm{dpm} / 100 \mathrm{~cm}^{2} \\
\left(60.07 \mathrm{~Bq} / 100 \mathrm{~cm}^{2}\right)\end{array}$ & Instrument packages & Trace amount \\
\hline $\mathrm{Cs}^{134}$ & $\begin{array}{l}0.848 \mathrm{pCi} / \mathrm{g} \\
(31.38 \mathrm{mBq} / \mathrm{g})\end{array}$ & Concrete & Trace amount \\
\hline $\mathrm{Cs}^{137}$ & $\begin{array}{l}260 \mathrm{pCi} / \text { filter } \\
(0.63 \mathrm{~Bq} / \text { filter })\end{array}$ & Rabbit tube smear & Trace amount \\
\hline $\mathrm{H}^{3}$ & $\begin{array}{l}15.6 \mathrm{pCi} / \mathrm{ml} \\
(577.2 \mathrm{mBq} / \mathrm{ml})\end{array}$ & Primary water & $\begin{array}{l}\text { Primary flush } \\
\text { water }\end{array}$ \\
\hline $\mathrm{Sr}^{90}$ & $\begin{array}{l}12 \mathrm{mCi} \\
(444 \mathrm{MBq})\end{array}$ & Radiation detectors & Sources \\
\hline $\mathrm{Mn}^{54}$ & $\begin{array}{l}0.7 \mathrm{pCi} / \mathrm{g} \\
(25.9 \mathrm{mBq} / \mathrm{g})\end{array}$ & Concrete & Trace amount \\
\hline
\end{tabular}


Table 5.2 Types and Locations of Hazardous Materials

\begin{tabular}{||l|l|l||}
\hline Hazardous Substance & \multicolumn{1}{c|}{ Location(s) Found } & \multicolumn{1}{c|}{ Remarks } \\
\hline \hline Asbestos & $\begin{array}{l}\text { Irsulation, pipe joint compound, and } \\
\text { electrical heat tape in rooms J-101, } \\
\text { J-102, J-105, J-002, J-010, and } \\
\text { J-014 }\end{array}$ & $\begin{array}{l}\text { Removed by licensed } \\
\text { contractor }\end{array}$ \\
\hline Lead-Based Paint & $\begin{array}{l}\text { Shutter air cylinders, shield blocks, } \\
\text { gasometer, heat exchangers, and air } \\
\text { storage tanks }\end{array}$ & $\begin{array}{l}\text { Items remaining were } \\
\text { stripped and repainted; items } \\
\text { removed were scrapped. }\end{array}$ \\
\hline Cadmium & $\begin{array}{l}\text { LiGe detector and low-dose room } \\
\text { storage pit }\end{array}$ & $\begin{array}{l}\text { Removed and transferred to } \\
\text { ANL-E for reuse }\end{array}$ \\
\hline Mercury & $\begin{array}{l}\text { Mercury switches and pressure } \\
\text { gauge }\end{array}$ & $\begin{array}{l}\text { Removed and transferred to } \\
\text { ANL-E for disposition }\end{array}$ \\
\hline
\end{tabular}

Table 5.3 Types and Locations of Mixed Waste

\begin{tabular}{||l|l|l||}
\hline \multicolumn{1}{|c|}{ Mixed Waste } & \multicolumn{1}{|c|}{ Location(s) Found } & \multicolumn{1}{c|}{ Remarks } \\
\hline \hline Gasometer Oil & Inside gasometer & Transferred to ANL-E for disposition \\
\hline Activated Lead & Top of reactor & $\begin{array}{l}\text { Packaged and transferred to ANL-E for } \\
\text { disposition }\end{array}$ \\
\hline Tainted Water & Base of reactor pedestal & Transferred to ANL-E for treatment \\
\hline
\end{tabular}




\subsection{DECONTAMINATION AND DISASSEMBLY OPERATIONS}

\subsection{General}

Afftrex divided the project into three phases. Each phase was further divided into major subtasks and then work packages. The JANUS D\&D Project work breakdown structure (WBS) is shown in Figure 6.1.

A detailed description of each phase of the JANUS D\&D Project is provided below.

\subsection{Pre-Subcontractor Preparation and Characterization}

\subsubsection{Project Preparations}

In November 1995, planning for the JANUS D\&D Project began. These activities consisted of preparing a facility characterization plan, a detailed cost/schedule plan, an Environmental Assessment (EA) of the D\&D activities, and other required plans and procedures for the D\&D work. Application was also made to the IEPA for an Air Discharge Permit.

\subsubsection{Facility Characterization}

During January and February 1996, ESH/HP performed a radiological and hazardous materials characterization of the JANUS Reactor facility. This characterization served as the basis for preparing the project's HASP and Auditable Safety Analysis (ASA) and for the air discharge permit application. Identified in the characterization were fifteen radioisotopes (predominately $\mathrm{Co}^{60}, \mathrm{Eu}^{152}$, and $\mathrm{Eu}^{154}$ ), twenty areas containing asbestos, seven items coated with lead-based paint and approximately 200,000 pounds of lead brick and block.

It should be noted that after the project began, four additional radioisotopes and two hazardous materials (mercury and cadmium) were identified. The additional radionuclides resulted from installed instrument check sources and posed no additional impact on worker or public safety. To ensure accuracy of disposal records, the radioactive waste characterizations were updated to include the additional nuclides. The cadmium was transferred to another ANL-E division for reuse. The mercury, which was in the form of sealed mercury switches and pressure gauges, was transferred to WMO for proper disposition. 


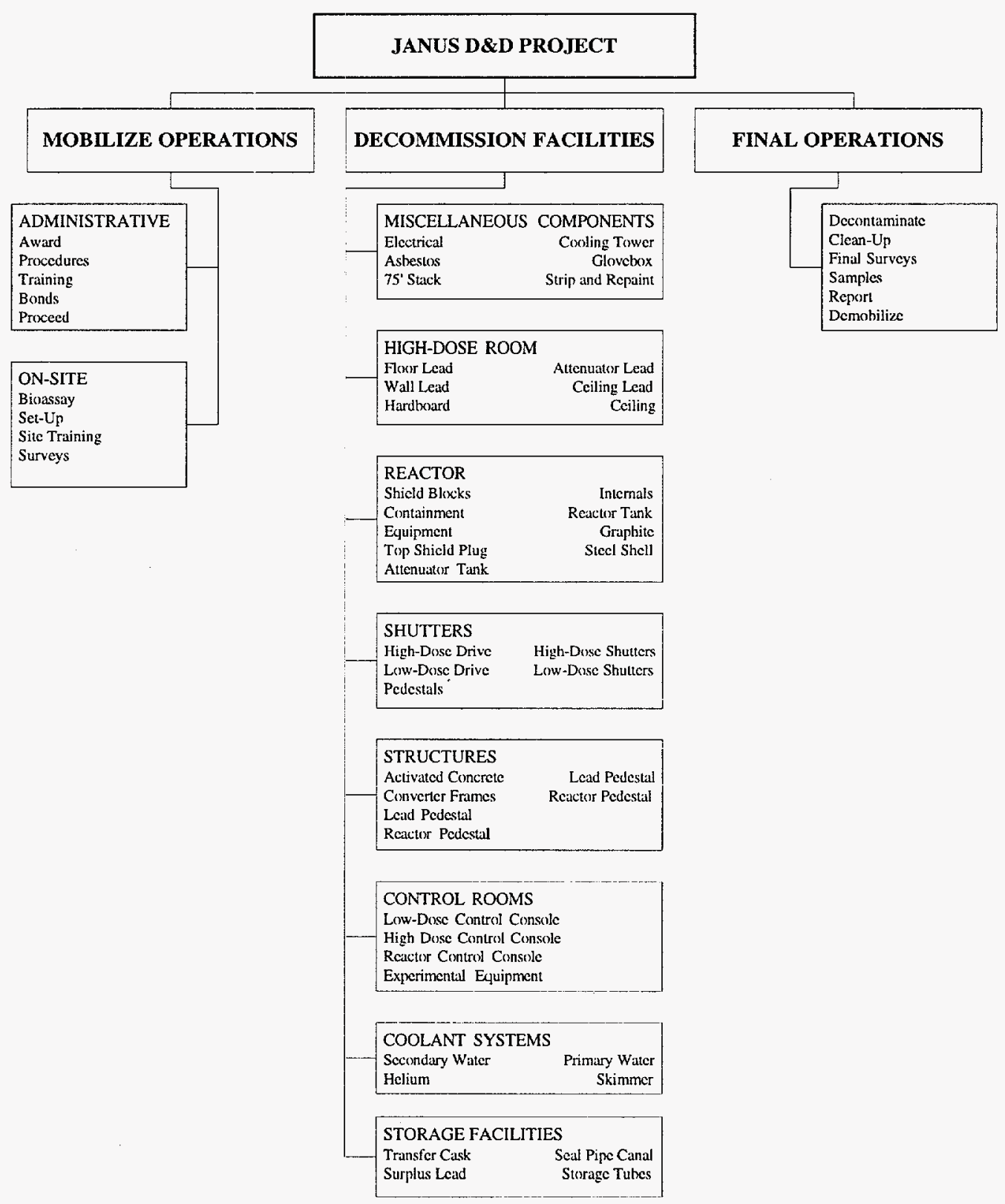

Figure 6.1 JANUS D\&D Project Work Breakdown Structure 


\subsection{Subcontractor Mobilization}

\subsubsection{Contract Award}

In November 1996, a contract for the D\&D of the JANUS Reactor facility was awarded to Afftrex, Ltd. of Pittsburgh, Pennsylvania. Prior to the start of on-site work, contract documents were finalized, performance bonds were submitted, and plans and procedures were provided for review and approval by ANL-E. After approval was granted, a preconstruction safety meeting was held at ANL-E on December 13, 1996. This meeting provided Afftrex management personnel an opportunity to meet with representatives from various groups at ANL-E involved in D\&D operations. Personnel from Industrial Hygiene, Safety Engineering, Fire Protection and Building Maintenance reviewed required notifications, permits and inspections. Health Physics discussed their oversight role as it related to the project. The Building 202 Manager reviewed requirements for building occupancy, vehicle parking, emergency response and emergency shelter assignments. Security personnel reviewed procedures for site access, deliveries, visitor access and ANL-E traffic regulations. Plant Facilities and Services discussed the process for obtaining assistance with systems and structures which are inside the subcontractor's work area but outside the subcontractor's scope of work. The Procurement Official reviewed procedures for submitting change orders.

\subsubsection{Mobilization}

Afftrex personnel and the MOTA Corporation Field engineer arrived at ANL-E on January 6, 1997 for a two-week, on-site training and orientation session. All contractor personnel were required to complete the following training: ANL-E Contractor Safety Orientation, Building 202 JANUS Facility Orientation, ANL-E Radiation Worker II training, OSHA 40-hour Hazardous Waste Site Operations training, ANL-E Radioactive Waste Generator training and ANL-E Lead Hazards and Control training. In addition, all personnel who performed health physics-related functions were required to be DOE-qualified Radiation Control Technicians (RCTs).

\subsubsection{H-Wing Set-Up}

In parallel with training and orientation activities, Afftrex set up project offices, crew facilities and equipment storage in H-Wing of Building 202. H-Wing is located in close proximity to J-Wing, where the D\&D activities were conducted.

\subsubsection{Pre-Work Bioassay and Whole Body Count}

During the two-week training and orientation session, each person working on the JANUS D\&D project was required to submit urine for bioassay and either provide documentation of an exit whole body count from their last assignment or undergo a whole body count at ANL-E. 


\subsubsection{Baseline Radiological Surveys}

Afftrex health physics personnel performed fixed and loose radiological surveys of the JANUS Reactor facility to verify its radiological status prior to beginning D\&D activities. General access Radiological Work Permits (RWPs) were generated based on the results of these surveys.

\subsection{Decommissioning Activities}

On-site D\&D activities began on January 22, 1997. Activities were not performed in the sequence or time frame presented in the original schedule due to procedure conflicts, delays in receipt of required equipment and supplies or non-availability of personnel to perform work when scheduled. The following task descriptions are based on the original project schedule (see Figure 10.2) for ease of presentation. Actual start and completion dates for each task are noted.

\subsubsection{Miscellaneous Components}

\subsubsection{Electrical System Isolation}

Electrical system isolation consisted of performing lockout/tagout (LO/TO) of circuits feeding power to equipment, components and panels scheduled for removal. A two-part LO/TO process was used to ensure that both project personnel and building maintenance personnel had knowledge regarding the electrical status of the facility. Project personnel identified circuits that were required to be de-energized and requested building maintenance to de-energize and LO/TO them. After completing LO/TO, building maintenance personnel verified the circuits were de-energized. Project personnel then installed their own LO/TOs and again verified that the circuits were de-energized. All LO/TO operations were performed in accordance with the ANL-E ESH Manual. Electrical isolation was started on January 28, 1997 and continued throughout the entire project.

\subsubsection{Asbestos Abatement}

The JANUS Reactor facility characterization identified 20 locations as having asbestos levels greater than $1 \%$ by weight. Afftrex subcontracted with SECO (Brookfield, Illinois), an Illinois-licensed asbestos abatement company, to remove the asbestos-containing materials (ACM). Table 6.1 lists the areas identified as having ACM. All ACM was surveyed prior to the start of asbestos abatement activities; none was suspected of being contaminated as a result of previous facility operations. Asbestos abatement began May 19, 1997 and was completed on June 3, 1997. A total of $513 \mathrm{ft}^{3}$ $\left(14.36 \mathrm{~m}^{3}\right)$ of asbestos waste was generated. All waste was transferred to WMO for disposal at a licensed disposal site. Figures 6.2 and 6.3 show asbestos work being performed in the JANUS Reactor facility. 
Table 6.1 Location of Asbestos-Containing Materials (ACM)

\begin{tabular}{|l|c|}
\hline Object & Room Location \\
\hline \hline Air conditioning duct (insulation) & $\mathrm{J}-101$ \\
\hline $\begin{array}{l}\text { Condensate pipe (pipe joint compound) } \\
\text { Steam pipe (pipe joint compound) } \\
\text { Air conditioning duct (insulation) }\end{array}$ & $\mathrm{J}-102$ \\
\hline $\begin{array}{l}\text { Condensate pipe (insulation) } \\
\text { Condensate pipe (pipe joint compound) } \\
\text { Steam pipe (pipe joint compound) }\end{array}$ & $\mathrm{J}-105$ \\
\hline $\begin{array}{l}\text { Condensate pipe (pipe joint compound) } \\
\text { Steam pipe (pipe joint compound) } \\
\text { Air conditioning duct (insulation) }\end{array}$ & $\mathrm{J}-002$ \\
\hline $\begin{array}{l}\text { Condensate pipe (pipe joint compound) } \\
\text { Steam pipe (pipe joint compound) } \\
\text { Air conditioning duct (insulation) } \\
\text { Laboratory cold water pipe (insulation) } \\
\text { Helium air dryer (electrical heat tape) }\end{array}$ & $\mathrm{J}-010$ \\
\hline $\begin{array}{l}\text { Condensate pipe (pipe joint compound) } \\
\text { Domestic hot water pipe (insulation) } \\
\text { Domestic cold water pipe (pipe joint compound) } \\
\begin{array}{l}\text { Steam pipe (pipe joint compound) } \\
\text { Laboratory cold water pipe (insulation) }\end{array}\end{array}$ \\
\hline
\end{tabular}




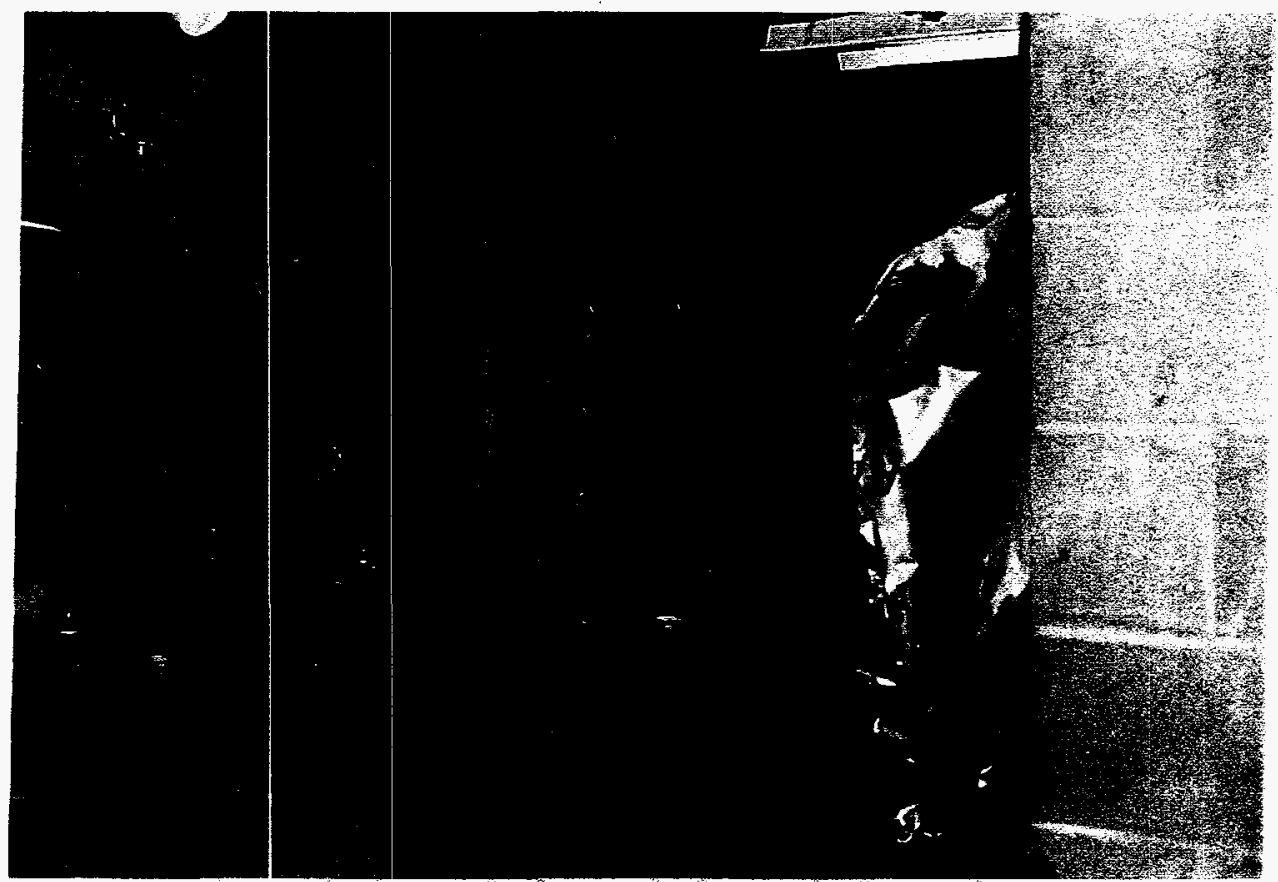

Figure 6.2 Preparing Fan Room for Asbestos Removal (ANL Negative \#23216K, Frame \#6A)
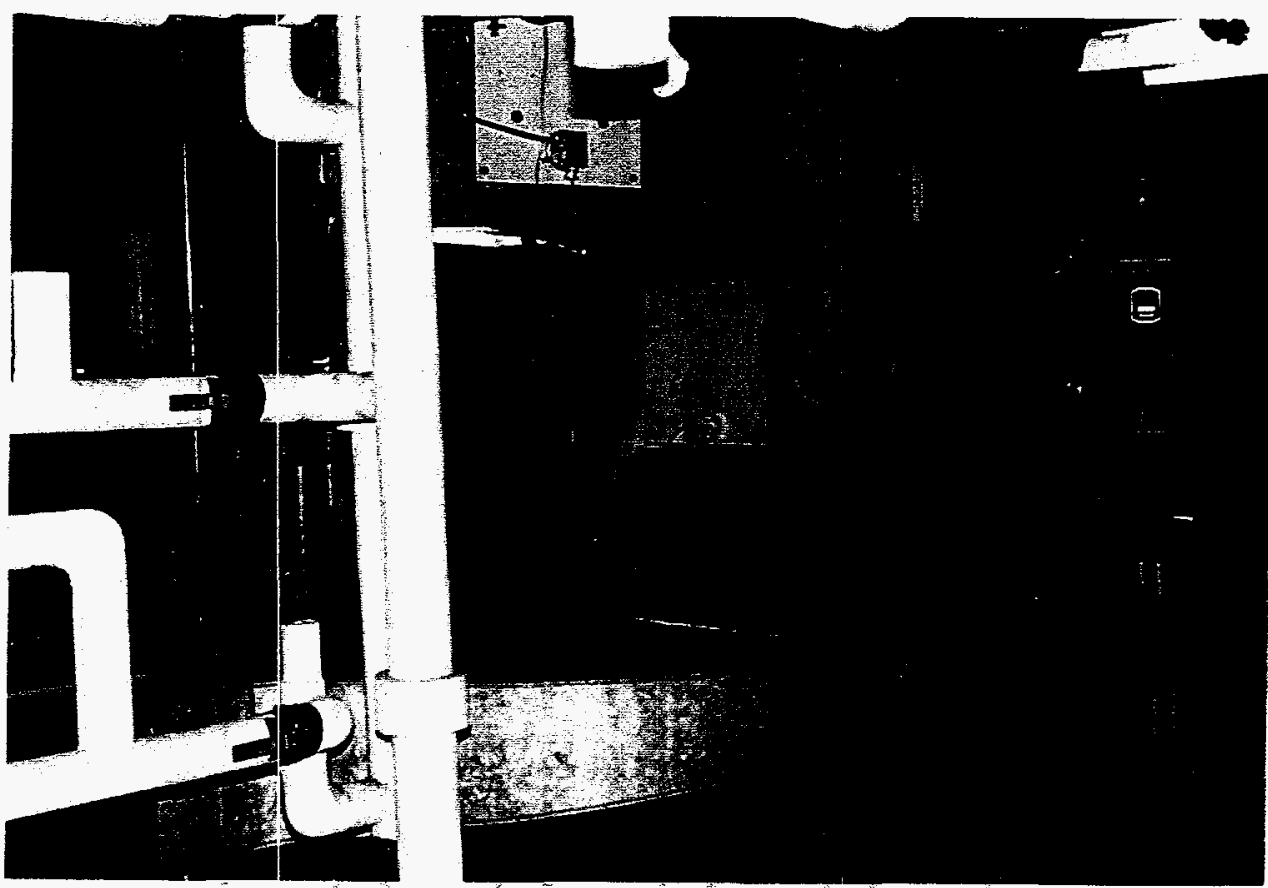

Figure 6.3 Fan Room After Asbestos Removal (ANL Negative \#23407K, Frame \#12A) 


\subsubsection{Exhaust Stack Removal}

The $75 \mathrm{ft}(22.86 \mathrm{~m})$ tall exhaust stack was located on the west side of the JANUS Reactor facility and was used to direct the discharge air from the installed HEPA system to the atmosphere. The installed HEPA system was required to be operational during all phases of D\&D; it was not removed until all D\&D work was completed. Afftrex subcontracted with Imperial Crane (Bridgeview, Ilinois) to remove the exhaust stack from Building 202. Photographs taken during stack installation proved invaluable in planning the removal operation. The removal was completed using a boom lift and crane on September 23, 1997 (see Figures 6.4 and 6.5).

\subsubsection{Cooling Tower Removal}

The cooling tower, used to dissipate heat removed by the secondary circulating water system to the atmosphere, was located on the north side of the reactor building. The original tower, which had fallen into deterioration, was replaced in 1988 with a structure that met or exceeded the requirement for cooling $140 \mathrm{gal} / \mathrm{min}(530 \mathrm{l} / \mathrm{min})$ of water from $100^{\circ} \mathrm{F}$ to $88^{\circ} \mathrm{F}\left(38^{\circ} \mathrm{C}\right.$ to $\left.31^{\circ} \mathrm{C}\right)$ at a wet bulb temperature of $78^{\circ} \mathrm{F}\left(26^{\circ} \mathrm{C}\right)$. The tower, including all support structures and systems, was mechanically dismantled and scrapped as clean trash (see Figures 6.6 and 6.7). Work was started on April 28, 1997 and completed on April 29, 1997.

\subsubsection{Glovebox Removal}

A glovebox located in Room J-120 on the northeast side of the JANUS Reactor facility had been originally installed to support experimentation, but it was never used. The glovebox was first disconnected from the attached ventilation system and relocated to a containment tent inside the high-bay area. It was then disassembled and free released as clean scrap. Associated ventilation duct work and HEPA filter were also removed from the facility. The HEPA housing was contaminated and disposed of as radioactive waste; the HEPA filter was transferred to WMO for size reduction and disposal. This subtask was started on March 12, 1997 and completed on April 18, 1997. Figures 6.8 and 6.9 show the removal and disassembly of the glovebox.

\subsubsection{Lead-Based Paint Removal}

During the March 1996 JANUS Reactor Facility characterization, several areas were identified as having been painted with lead-based paint. Those building structures and floor plugs which were not identified for demolition were stripped of their lead-based paint and repainted with lead-free paint. Table 6.2 lists those items identified as having lead-based paint and their final status at project completion. In addition to the items identified during the characterization, a number of other items were discovered during the performance of the D\&D activities as having lead-based paint; these items are also included in Table 6.2. To strip away the paint, Peel Away ${ }^{\mathrm{TM}}$ paint remover was applied to the items. The paint residue was collected on paper and rags, and packaged as hazardous waste. All waste was transferred to WMO for final disposition. This work was started on April 2, 1997 and completed on July 31, 1997. Paint removal operations at the JANUS Reactor facility are shown in Figures 6.10 and 6.11. 


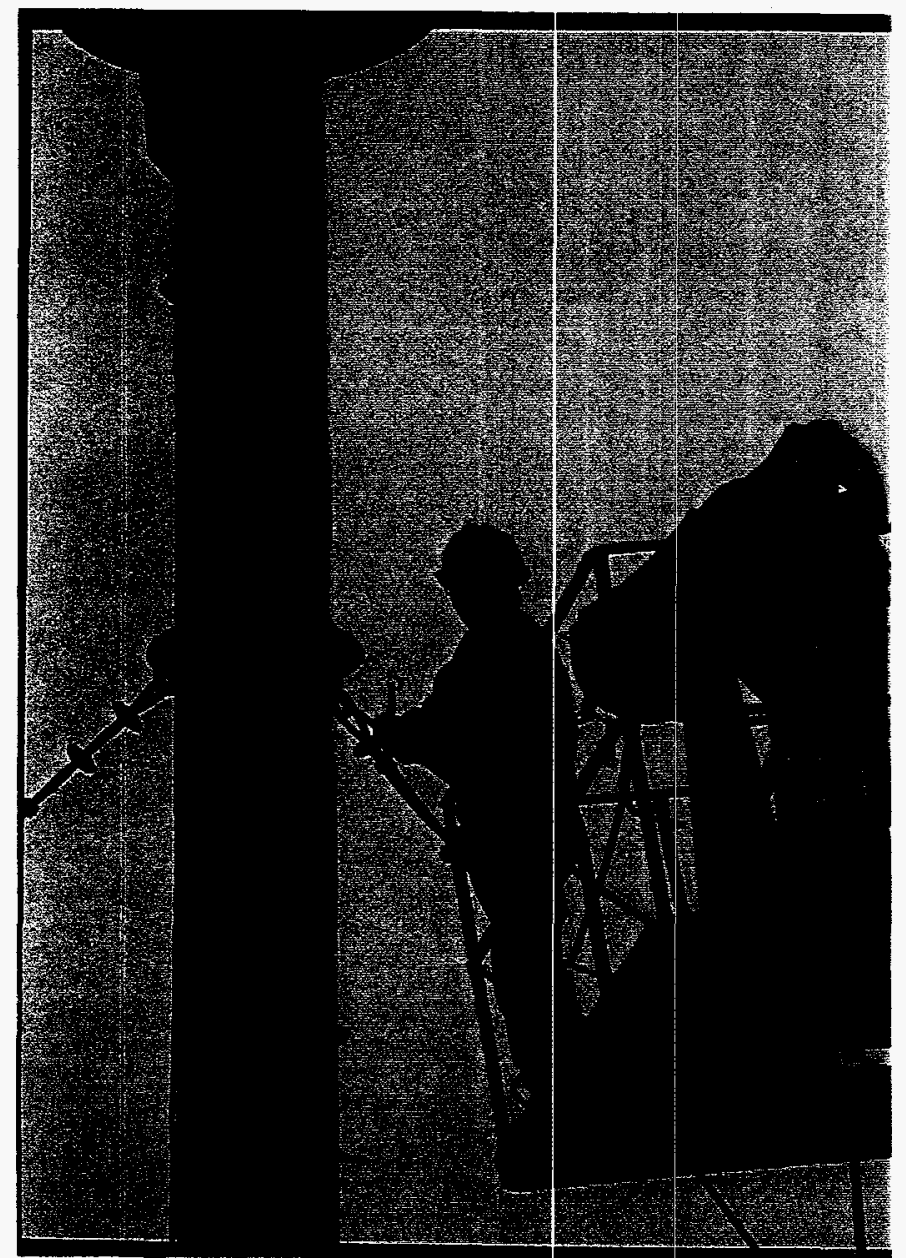

Figure 6.4 Preparing for Exhaust Stack Removal

(ANL Negative \#23618K, Frame \#4A)

Figure 6.5 Exhaust Stack Being Removed (ANL Negative \#23605K, Frame \#15A) 


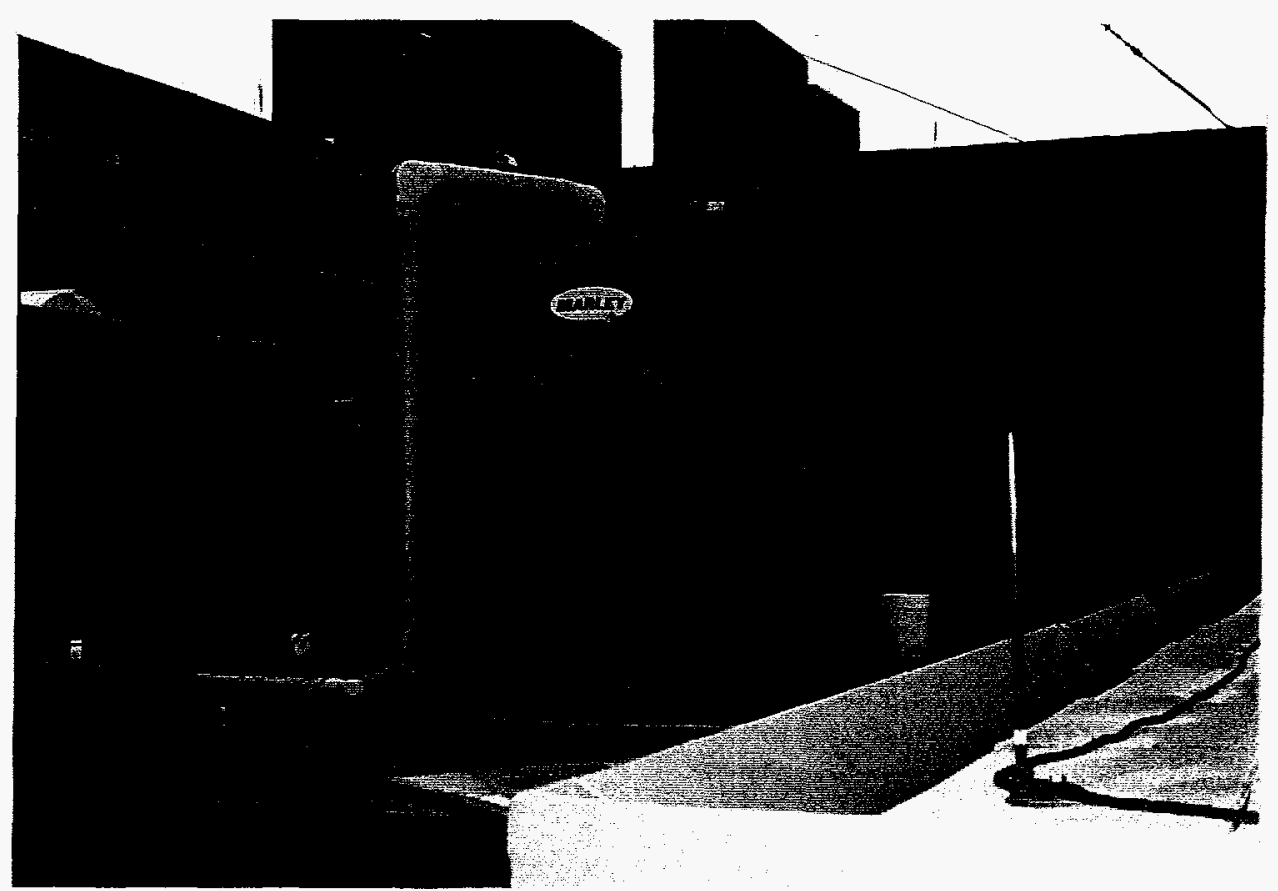

Figure 6.6 Cooling Tower During Disassembly (ANL Negative \#23136K, Frame \#8A)

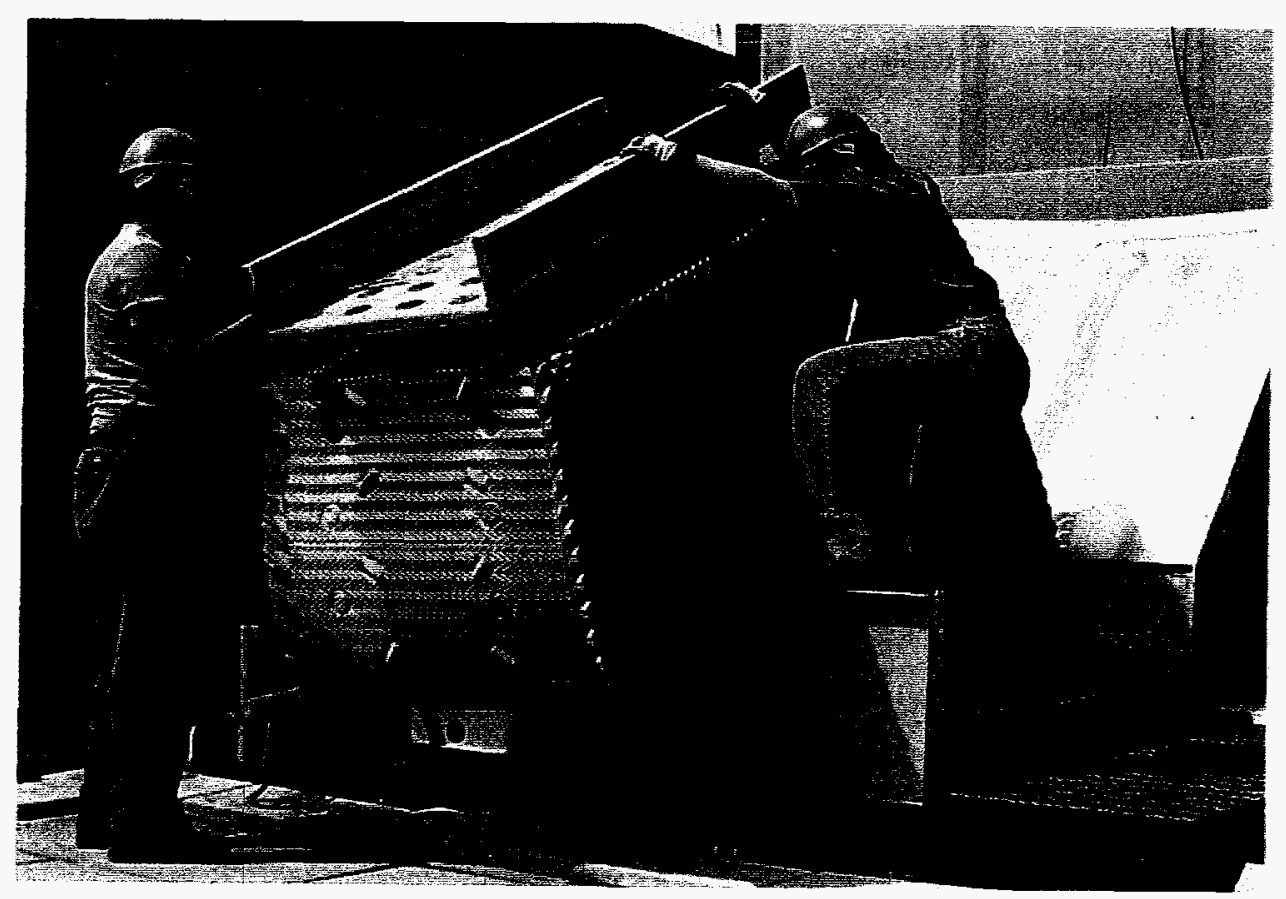

Figure 6.7 Technicians Removing Cooling Coils (ANL Negative \#23136K, Frame \#16A) 


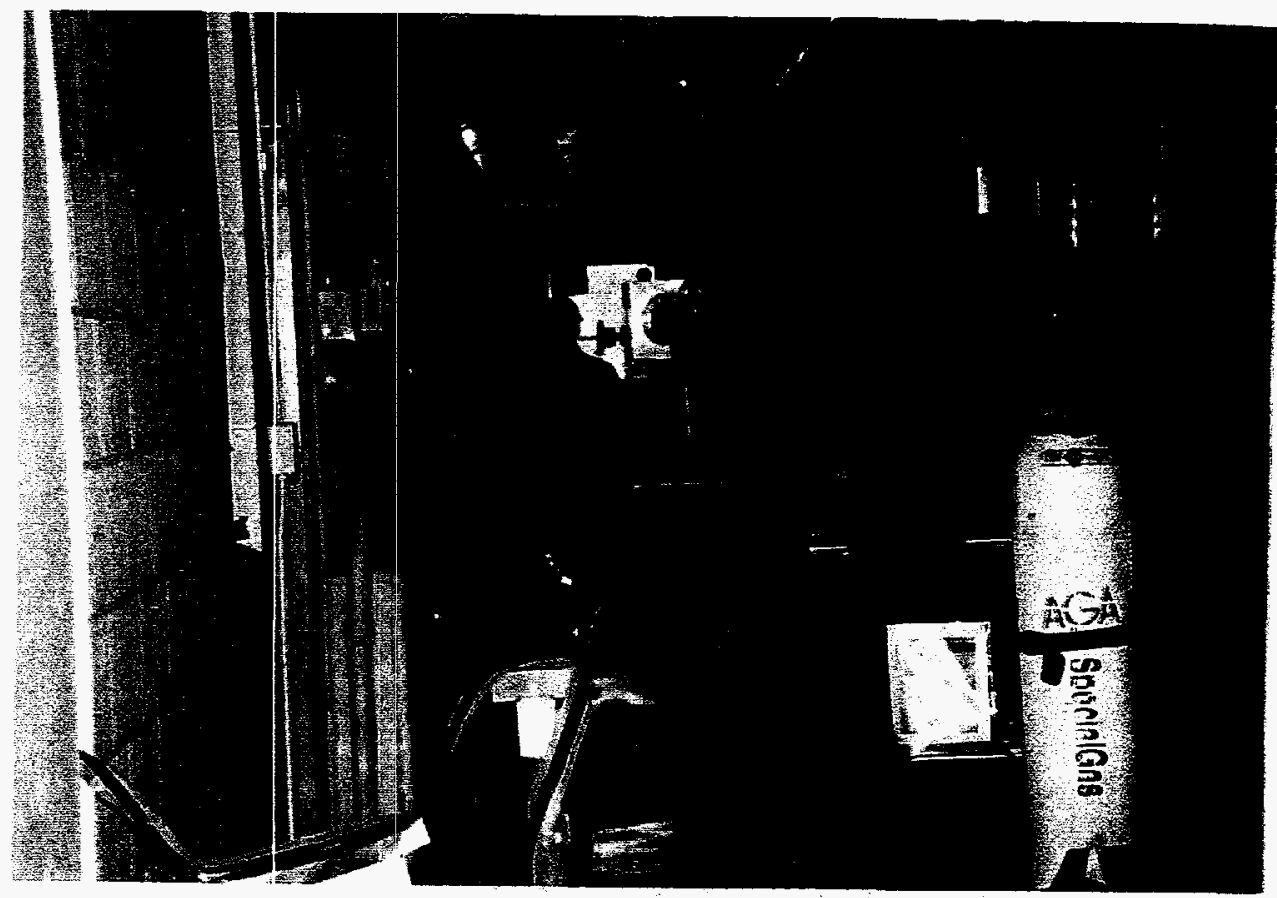

Figure 6.8 Relocating Glovebox from Room J-120 to Containment for Disassembly (ANL Negative \#22846K, Frame \#8A)

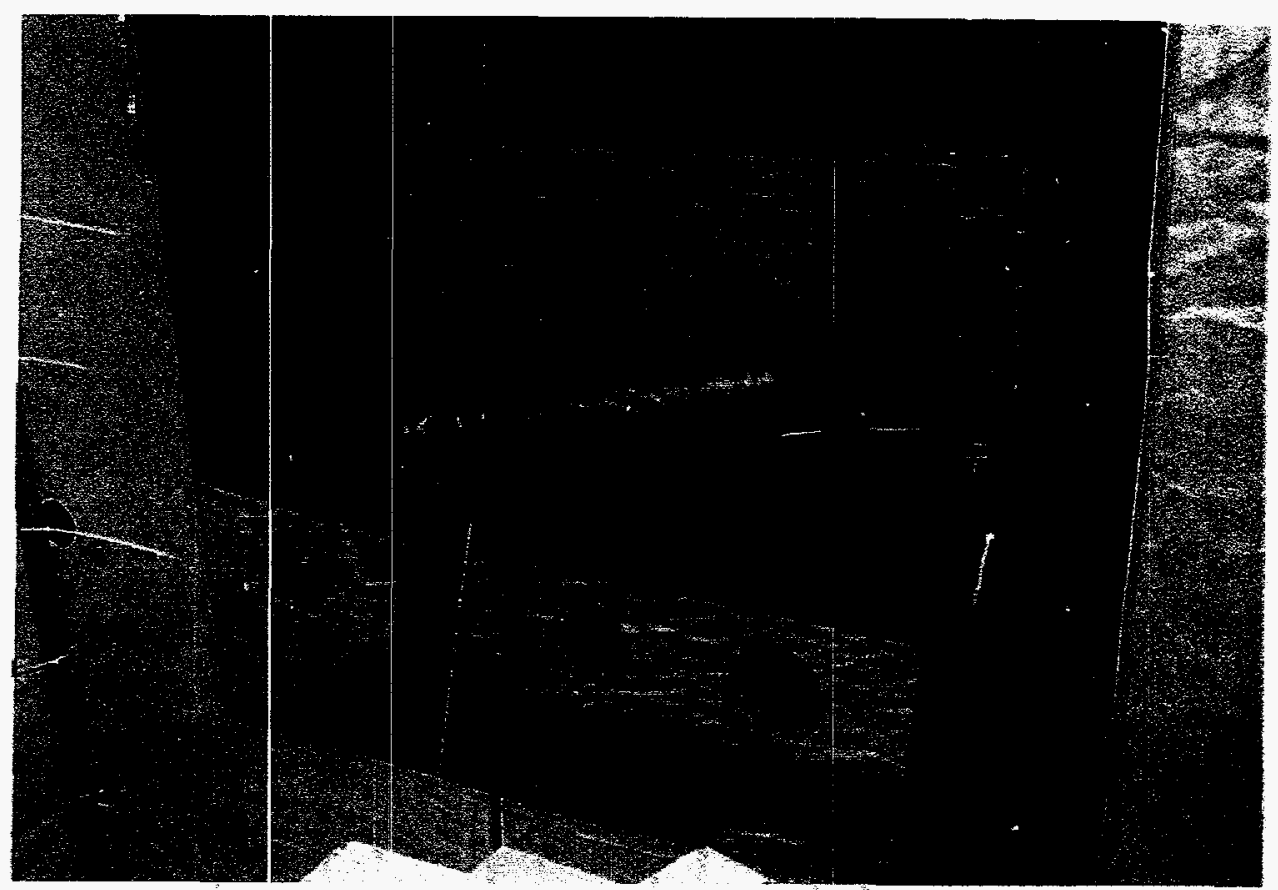

Figure 6.9 Partially Disassembled Glovebox Inside Containment (ANL Negative \#22846K, Frame \#11A) 


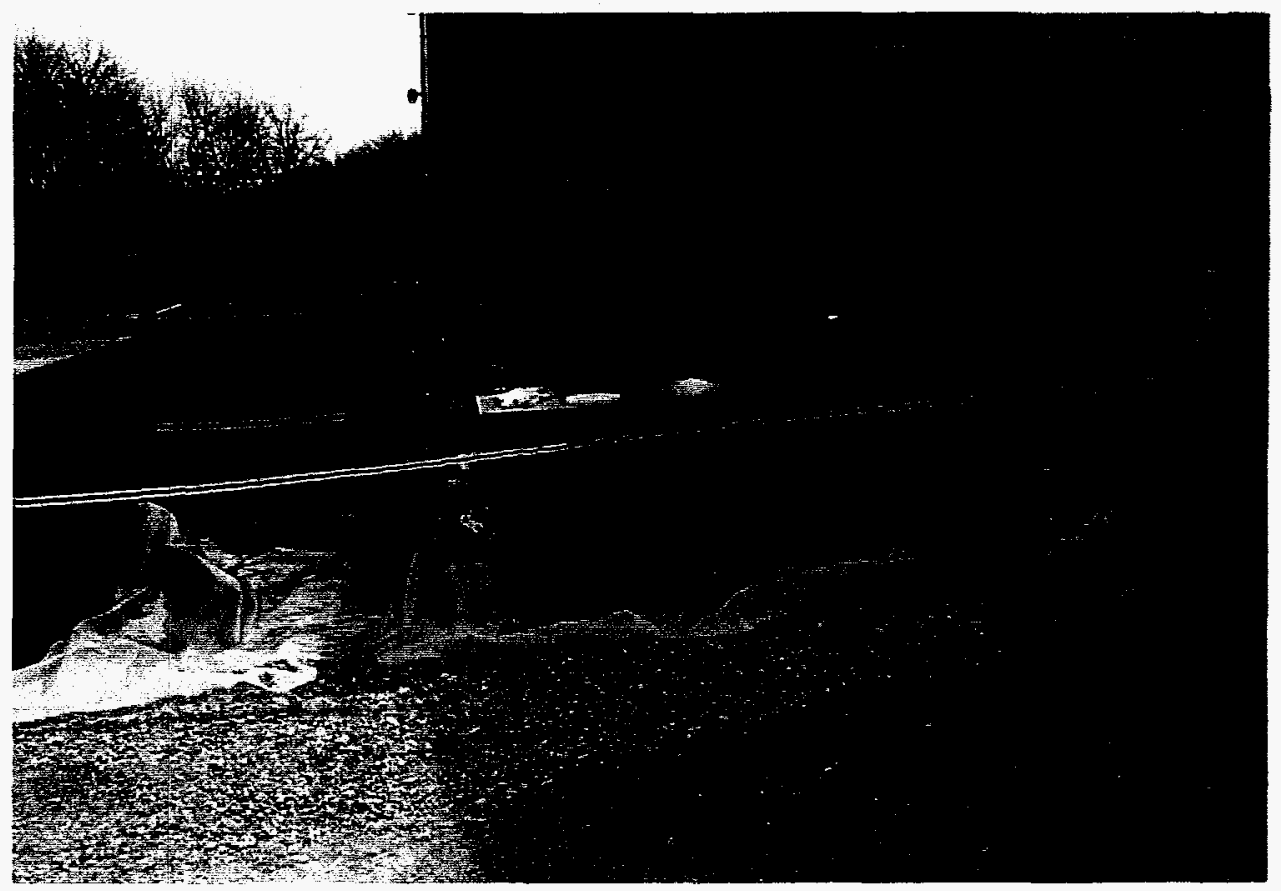

Figure 6.10 Stripping Lead-Based Paint from a Floor Plug (ANL Negative \#22981K, Fame \#12)

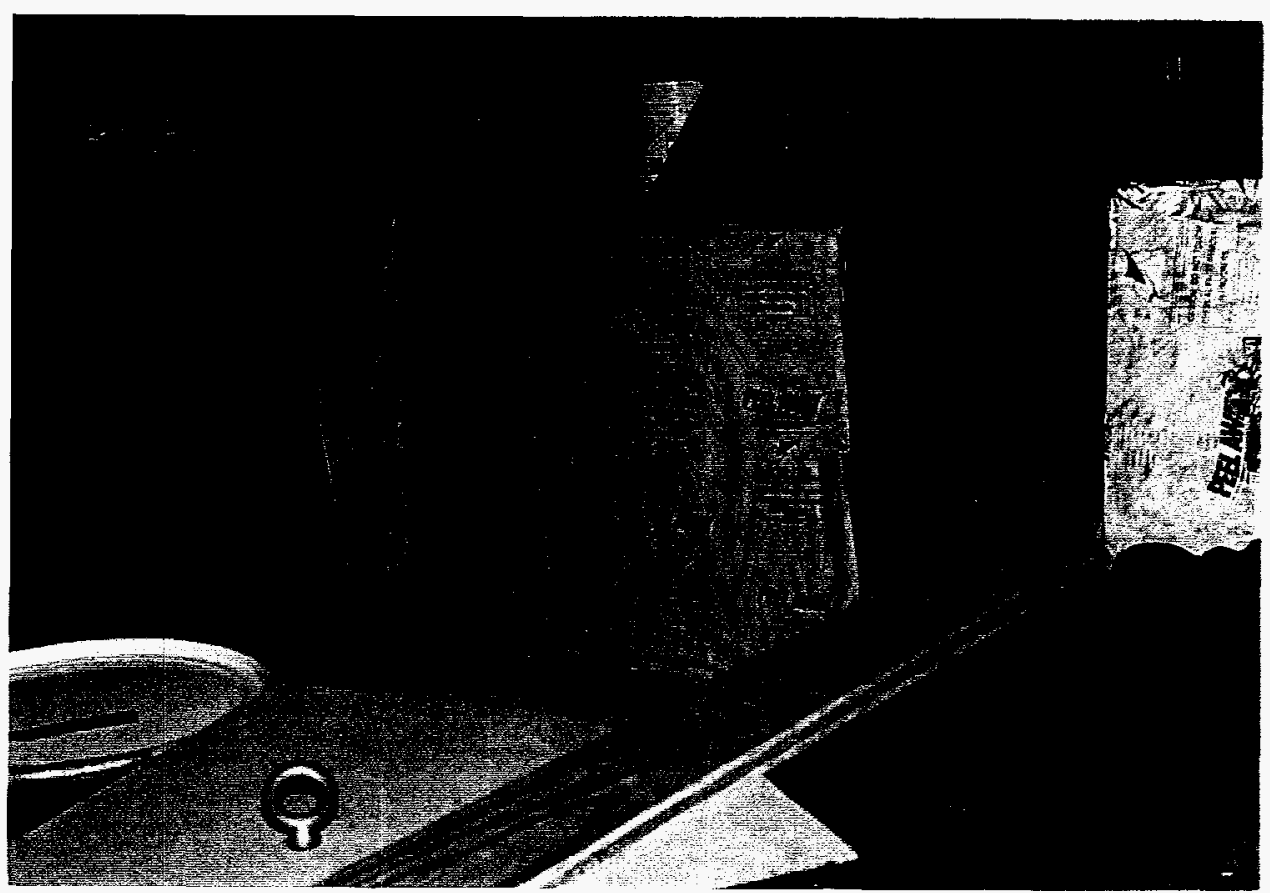

Figure 6.11 Paint Stripper Applied to a Reactor Floor Plug (ANL Negative \#23153K, Frame \#18A) 
JANUS D\&D Project

Final Report

Page 38 of 111

Table 6.2 Items Identified As Having Lead-Based Paint

\begin{tabular}{||l|c|l||}
\hline Item Identified & Location Found & Final Disposition \\
\hline \hline Shutter air cylinder platform & $\mathrm{J}-105$ & Disposed of as clean scrap \\
\hline Floor plugs above reactor & $\mathrm{J}-105$ & Stripped and repainted \\
\hline Floor plugs above high-dose room & $\mathrm{J}-105$ & Stripped and repainted \\
\hline Floor plugs above low-dose room & $\mathrm{J}-105$ & Stripped and repainted \\
\hline Openings for floor plugs & $\mathrm{J}-105$ & Stripped and repainted \\
\hline I-beam supports for floor plugs & $\mathrm{J}-105$ & Left in place \\
\hline Gasometer in reactor equiprnent room & $\mathrm{J}-010$ & Disposed of as clean scrap \\
\hline Heat exchanger in pump room & $\mathrm{J}-010$ & Disposed of as clean scrap \\
\hline Shutter air receiver tanks & $\mathrm{J}-101$ & Disposed of as clean scrap \\
\hline \hline
\end{tabular}

\subsubsection{High-Dose Room Demolition}

The high-dose room, an $8 \mathrm{ft} \times 16 \mathrm{ft}(2.44 \mathrm{~m} \times 4.88 \mathrm{~m})$ concrete cell with a $10 \mathrm{ft}(3.05 \mathrm{~m})$ tall ceiling, was located on the west side of the reactor. It was used for studying acute biological effects $\left(10^{5}\right.$ to $10^{6} \mathrm{rad} /$ week $(1,000$ to $10,000 \mathrm{~Gy} /$ week $\left.)\right)$ of fission neutrons. In 1969 , the room was modified to eliminate neutron leakage through and around the high-dose shutters; to shield personnel and experiments from exposure from the activated walls, ceiling and floor; and to reduce exposure rates in the reactor workroom and control room. The modifications included installation of a $1 \mathrm{ft}$ $(3.48 \mathrm{~cm})$ thick borobauxite concrete false ceiling; installation of 4 in $(10.16 \mathrm{~cm})$ of borated hardboard to the walls and floor; installation of 4 in $(10.16 \mathrm{~cm})$ of lead to the floor, walls and false ceiling; replacement of the existing concrete and steel high-dose shutters and pedestals with polyethylene and lead shutters and pedestals; and installation of a 9 in $(22.86 \mathrm{~cm})$ thick lead gamma shield over the high-dose face. The following describes each phase of the high-dose room demolition.

\subsubsection{Floor Lead Removal}

Floor lead removal consisted of removing two 0.125 in $(0.318 \mathrm{~cm})$ thick lead sheets located above two layers of lead bricks measuring 2 in $\times 2$ in $\times 4$ in $(5.08 \mathrm{~cm} \times 5.08 \mathrm{~cm} \mathrm{x} 10.16 \mathrm{~cm})$ that covered the floor. The lead sheets were rolled up and removed to expose the two layers of lead brick, which were then manually removed. All lead material was surveyed for free release, stacked on pallets and wrapped with plastic to prevent lead contamination of surrounding areas. The lead was transferred to the ANL-E lead bank for reuse by another ANL-E facility. Approximately $25,000 \mathrm{lb}(11,340 \mathrm{~kg})$ 
of lead was removed from the high-dose room floor between February 3, 1997 and March 14, 1997. Figures 6.12 and 6.13 show the removal of lead from the high-dose room floor.

\subsubsection{Wall Lead Removal}

Wall lead removal consisted of removing the 4 in $\times 4$ in $\times 2 \mathrm{ft}(10.16 \mathrm{~cm} \times 10.16 \mathrm{~cm} \times 60.96 \mathrm{~cm})$ chevron-shaped lead blocks that completely lined the walls of the high-dose room. Originally it was thought that the blocks were fused together at the surface to a depth of approximately 0.25 in $(0.635$ $\mathrm{cm})$. It was determined, however, that during construction a gap of approximately 1 in $(2.54 \mathrm{~cm})$ had been left between each adjoining block. As each tier of block was installed, the gap was filled with molten lead which fused adjoining blocks together as well as fusing them to a 1 in $(2.54 \mathrm{~cm})$ thick lead backing plate bolted to the concrete wall behind each butt joint. This construction method formed a continuous 4 in $(10.16 \mathrm{~cm})$ thick lead wall with no joints or seams.

Various lead-cutting techniques were tested to identify a safe, cost-effective method of removing the wall lead. Electric chisels merely pushed the lead around and were easily wedged. A router produced good results to a depth of 0.5 in $(1.27 \mathrm{~cm})$, but melting of the lead at greater depths caused binding. A circular saw fitted with a non-ferrous metal cutting blade produced good results, but the depth of cut was limited to about 3.5 in $(8.89 \mathrm{~cm})$. The circular saw cut the lead wall in progressive cuts of 0.5 in $(1.27 \mathrm{~cm})$ depth per pass, at a rate of one brick every two min. An electric chain saw proved to work most effectively. The cutting rate was approximately one brick every $90 \mathrm{sec}$ at the full 4 in $(10.16 \mathrm{~cm})$ depth. In addition, the electric chain saw worked well in corners, i.e., areas not accessible with the circular saw. Although the chain saw's nylon drive sprocket required several replacements during wall removal operations, the chain never needed sharpening. A combination of the circular saw and electric chain saw was used to remove the 320 lead wall bricks, weighing approximately $47,000 \mathrm{lb}(21,319 \mathrm{~kg})$. The lead was surveyed for free release and transferred to the ANL-E lead bank for reuse. This task started on February 5, 1997 and completed on March 14, 1997. Wall lead removal operations in the high-dose room are shown in Figures 6.14 and 6.15.

\subsubsection{Hardboard Removal}

After the lead was removed from the walls and floor, the four layers of 1 in $(2.54 \mathrm{~cm})$ thick borated hardboard were removed. The hardboard, which was bolted to the concrete walls, was removed by unfastening the bolts and manually removing each section (see Figures 6.16 and 6.17). The hardboard was surveyed for free release and disposed of as clean scrap. This activity started on March 7, 1997 and completed on March 14, 1997. 


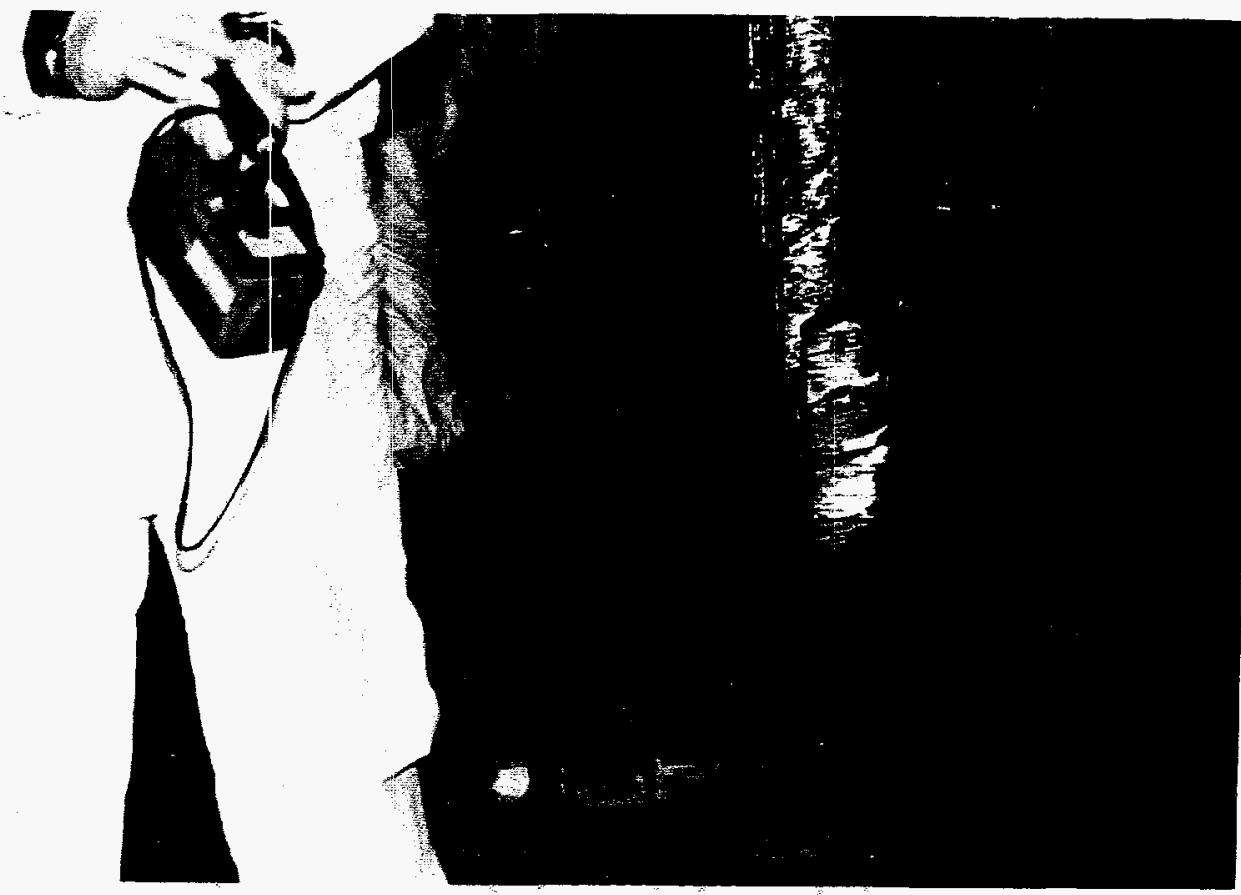

Figures 6.12 Removing Lead Bricks from High-Dose Room Floor (ANL Negative \#22846K, Frame \#3A)

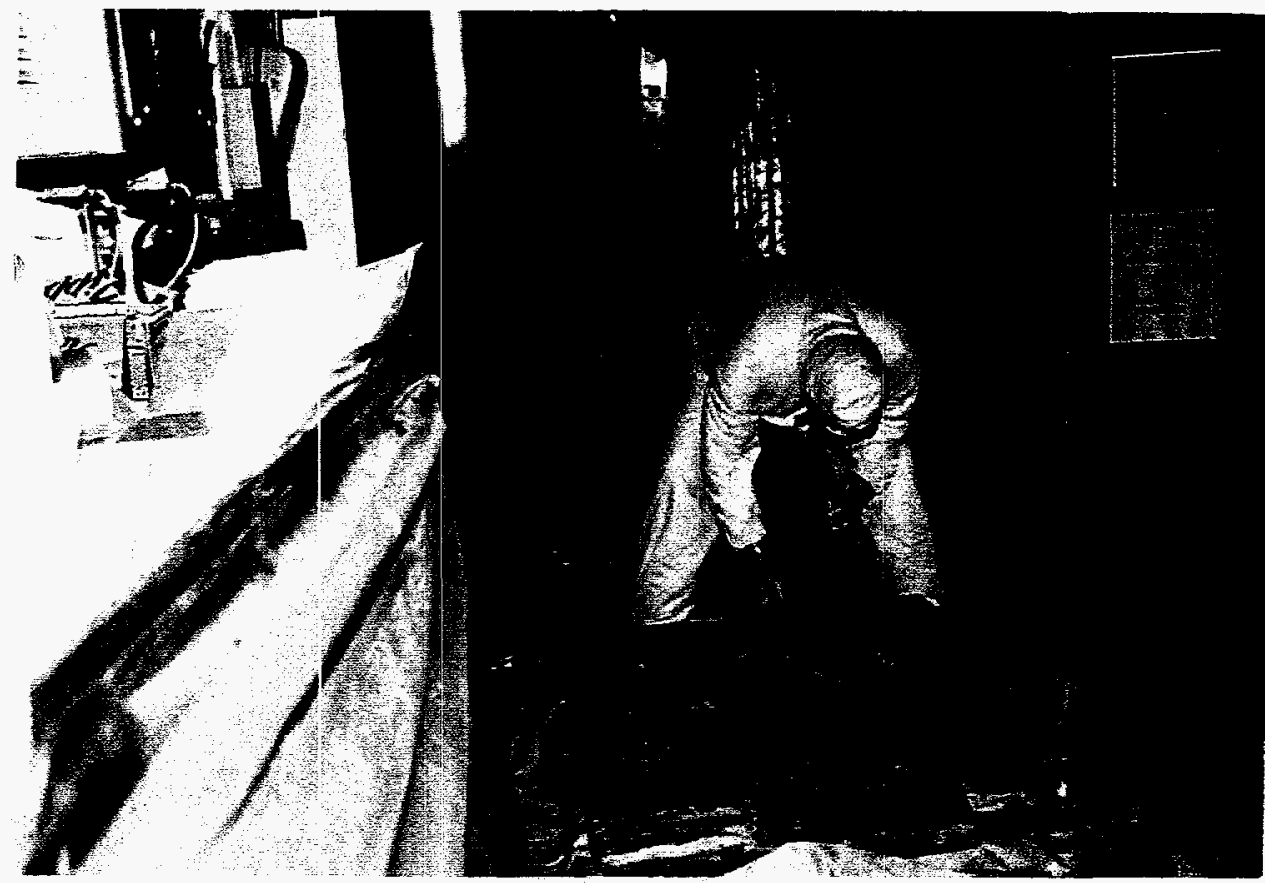

Figure 6.13 Radiological Control Technician Surveying Floor Lead After Removal (ANL Negative \#22846K, Frame \#2A) 


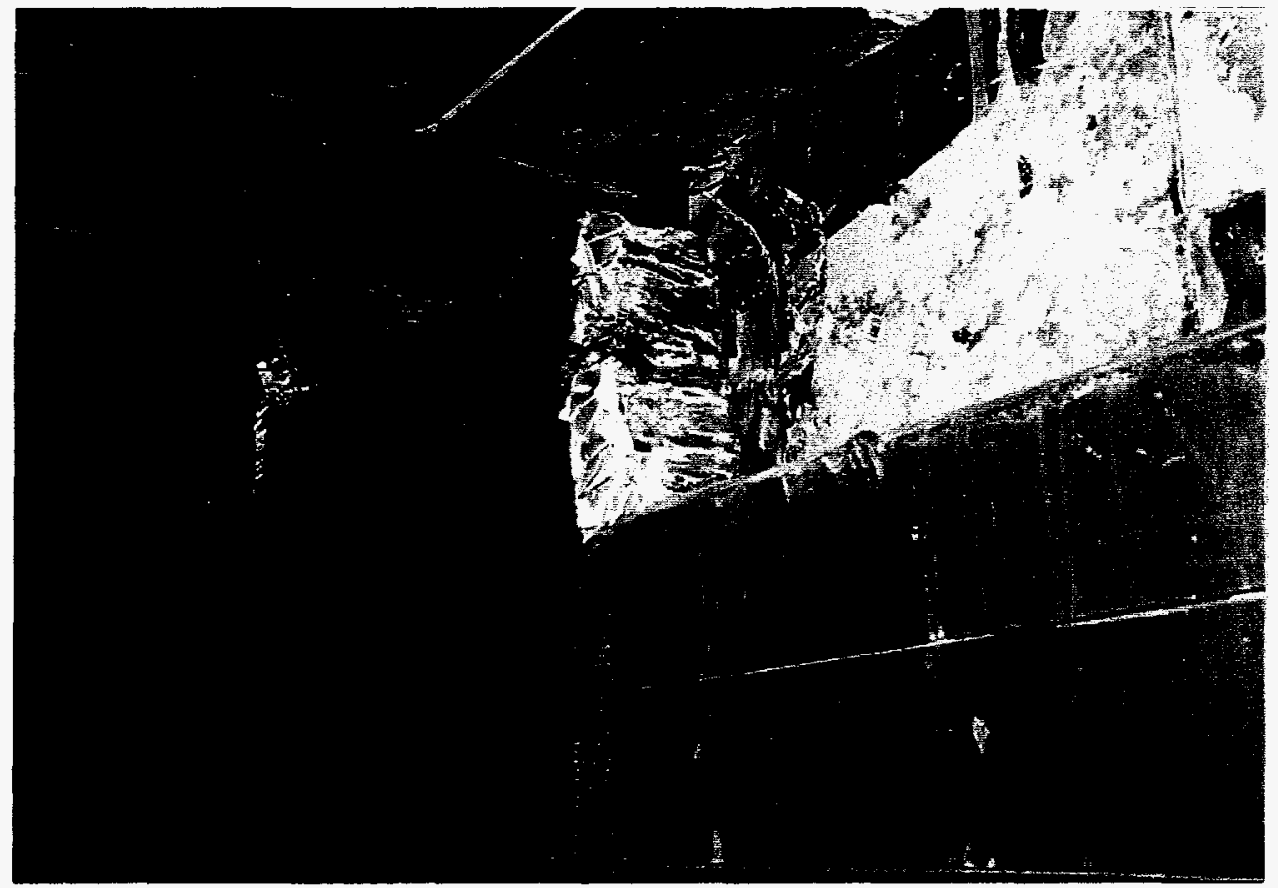

Figure 6.14 High-Dose Room Lead Wall Block Showing Full Depth Joint Weld (ANL Negative \#22760K, Frame \#12A)

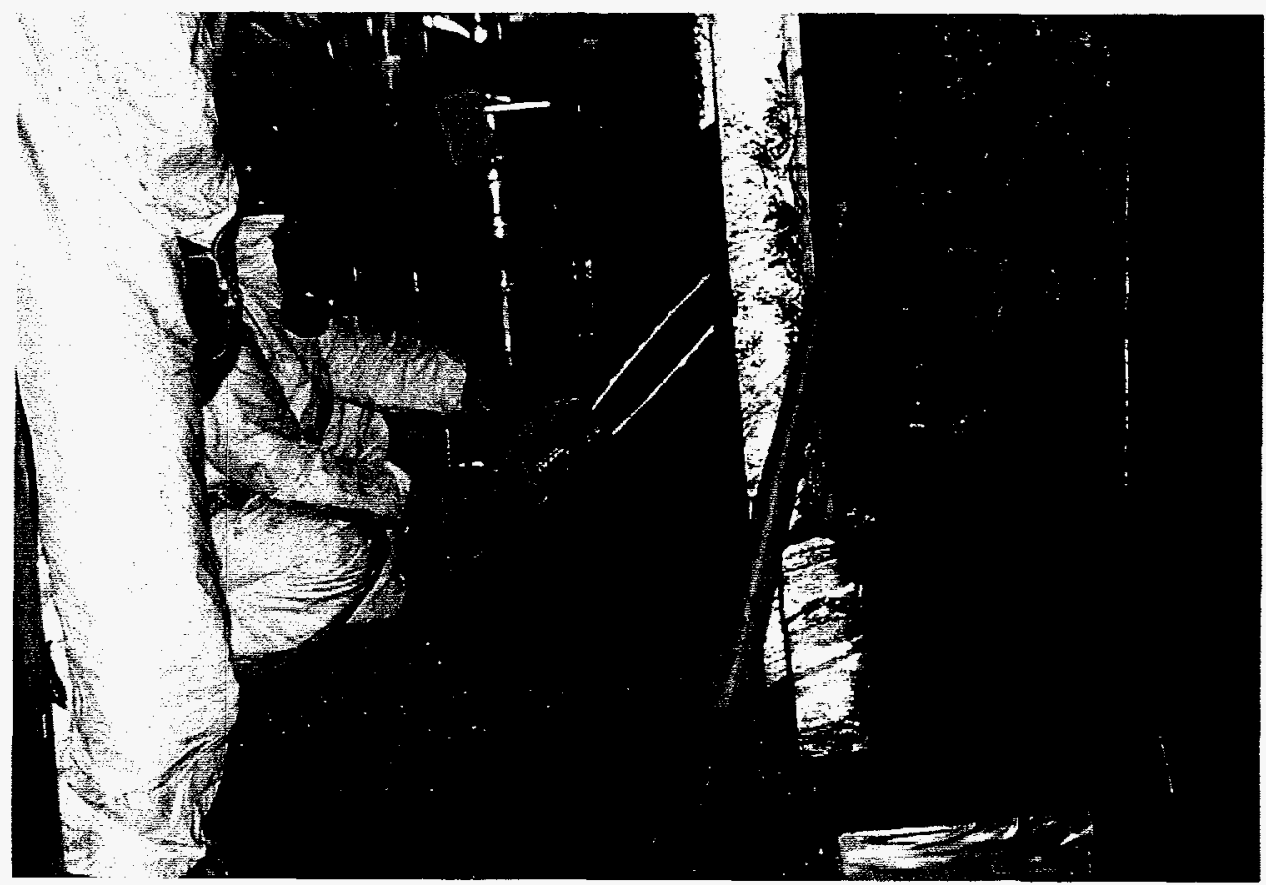

Figure 6.15 Sawing Lead Wall Blocks with Electric Chain Saw (ANL Negative \#22760K, Frame \#23A) 


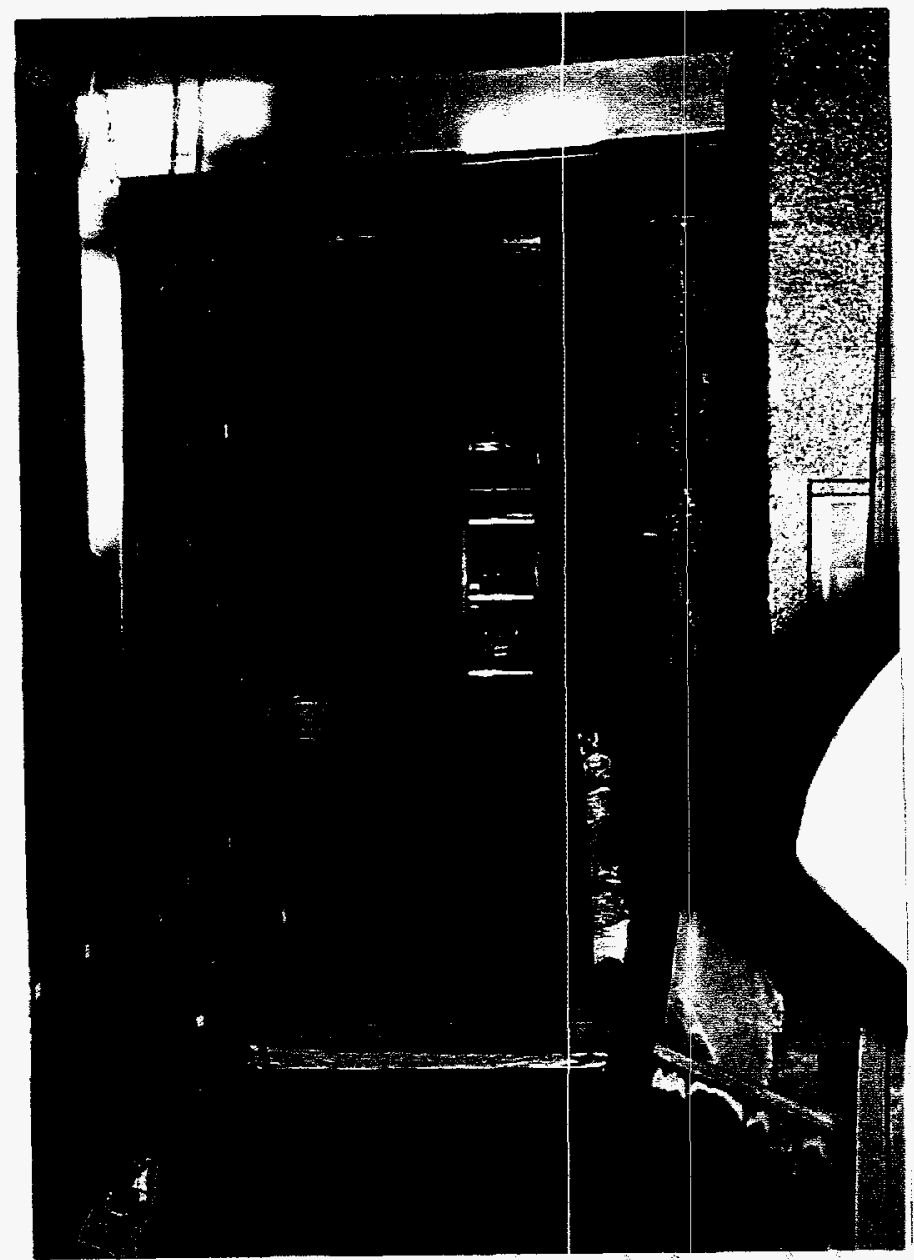

Figure 6.16 View of High-Dose Room During Hardboard Removal (ANL Negative \#22846K, Frame \#14A)

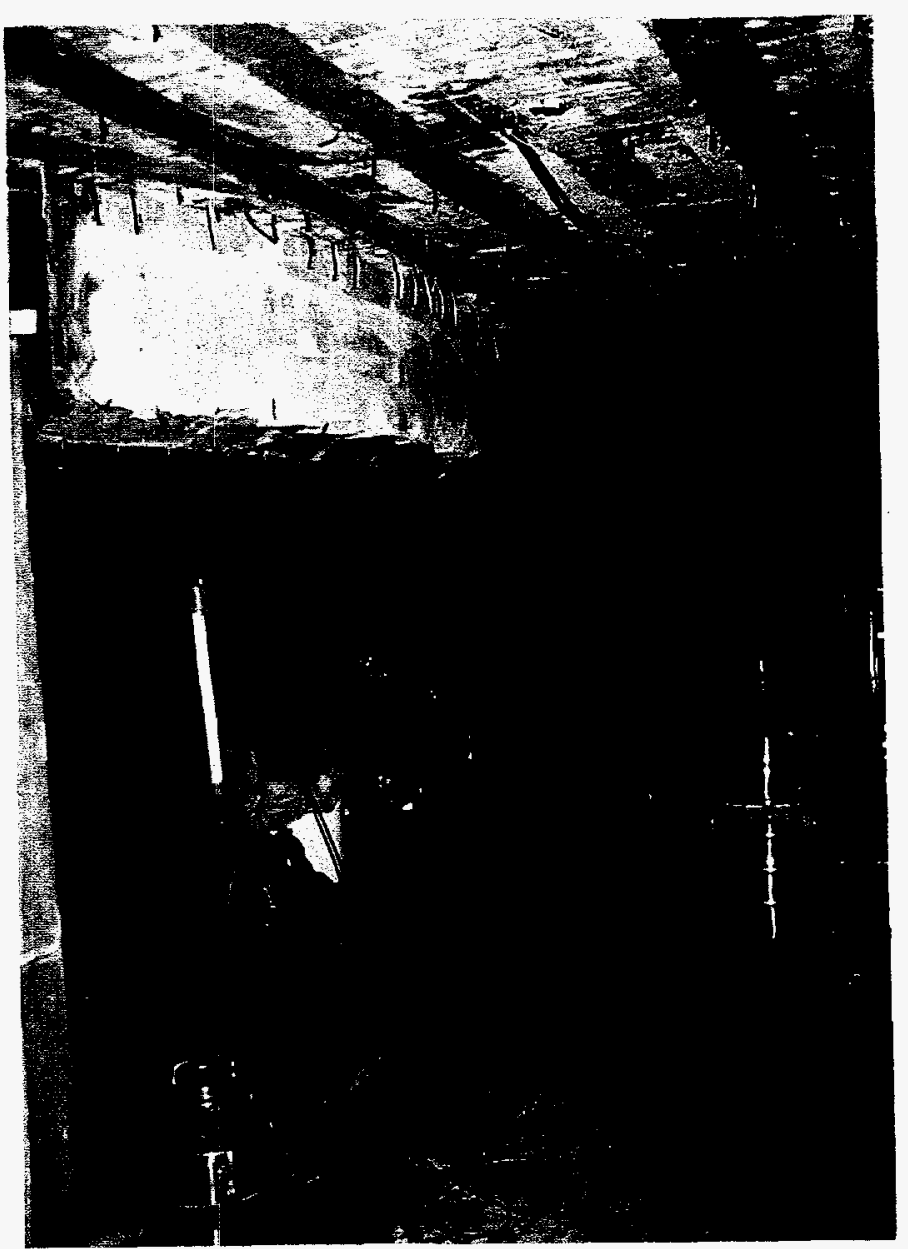

Figure 6.17 Hardboard Removal in High-Dose Room

(ANL Negative \#22891K, Frame \#10) 


\subsubsection{Attenuator Lead Removal}

In front of the high-level face were nine layers of lead plate, each measuring 1 in thick $x 6$ in wide $\mathrm{x} 48$ in tall $(2.54 \mathrm{~cm} \mathrm{x} 15.24 \mathrm{~cm} \times 121.92 \mathrm{~cm})$. These plates formed a gamma shield between the reactor face and the high-dose room which allowed personnel to enter during reactor operation. Two of the nine layers of lead had already been removed and stacked on the floor in the high-dose room to facilitate removal of the fuel bearing converter plate. The remaining seven layers of lead plate, weighing approximately $23,000 \mathrm{lb}(10,432 \mathrm{~kg})$, were manually removed, surveyed for free release and transferred to the ANL-E lead bank for reuse. This work started on March 6, 1997 and was completed on March 17, 1997. Figures 6.18 and 6.19 show the attenuator wall removal.

\subsubsection{Ceiling Lead Removal}

Attached to the false borobauxite concrete ceiling in the high-dose room were 4 in $(10.16 \mathrm{~cm})$ thick interlocking lead ceiling, soffit and face tiles. These tiles were attached to aluminum grating supported by an I-beam. To support the lead tiles, four aluminum rods were cast into each lead block; the free ends of the rods were then inserted through the grating, and washers and nuts were attached to the ends of the rods. After the lead ceiling was installed, a $1 \mathrm{ft}(3.48 \mathrm{~cm})$ thick borobauxite concrete false ceiling was poured onto the grating. The concrete covered the nuts and washers, preventing easy access. Because the ceiling tiles were interlocking and installation had begun in the northeast corner of the ceiling and finished in the southwest corner, tile removal had to be performed precisely opposite of installation. Removal started in the southwest corner, with each block being supported by a battery-operated lift cart. Support rods were then cut and the tile lowered to the floor, where it was surveyed for free release and transferred to the ANL-E lead bank for reuse. Approximately $27,000 \mathrm{lb}(12,247 \mathrm{~kg})$ of lead was removed from the high-dose room ceiling between February 21, 1997 and February 26, 1997 (see Figures 6.20 and 6.21).

\subsubsection{Ceiling and Equipment Removal}

After removing the lead from the high-dose room ceiling, floor and walls, the equipment located above the false ceiling (attenuator and converter drives, air tanks and associated piping and wiring) was removed. First the floor plugs were removed from above the high-dose room and a containment tent constructed. The area was classified as a permit-required confined space; air monitoring, retrieval capability and a full-time attendant during entry were required during equipment removal. The equipment was mechanically disassembled and removed through the floor opening. After the equipment was removed, electric jackhammers were used to remove the false ceiling. The ceiling support structure, made up of I-beams and grating, was removed using electric cut-off saws. The equipment, concrete rubble and ceiling support structure were packaged as low-level radioactive waste. These activities were started on March 28, 1997 and completed on April 15, 1997. Figures 6.22 and 6.23 show the removal of equipment and false ceiling above the high-dose room. 


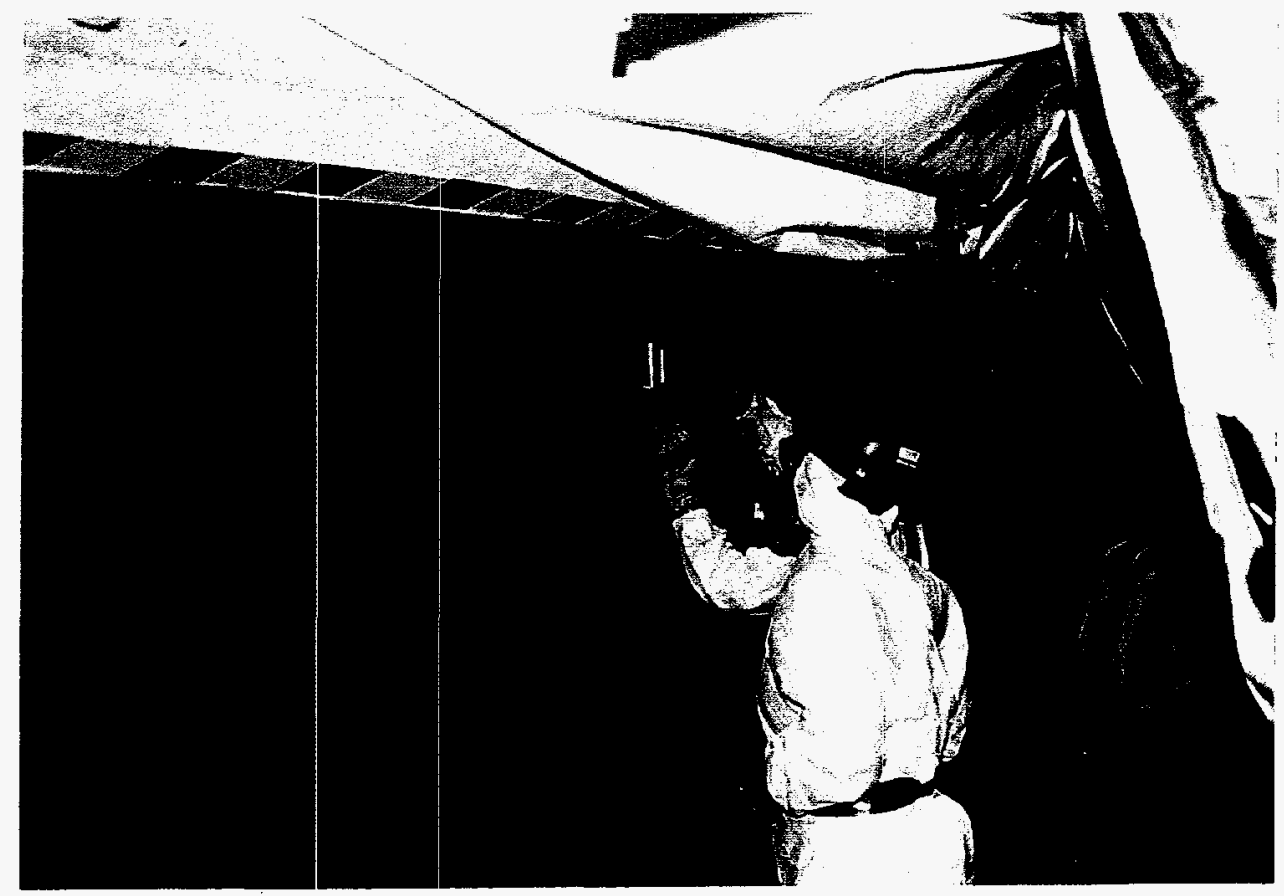

Figure 6.18 Removing Attenuator Lead from Low-Dose Face (ANL Negative \#22891, Frame \#4)

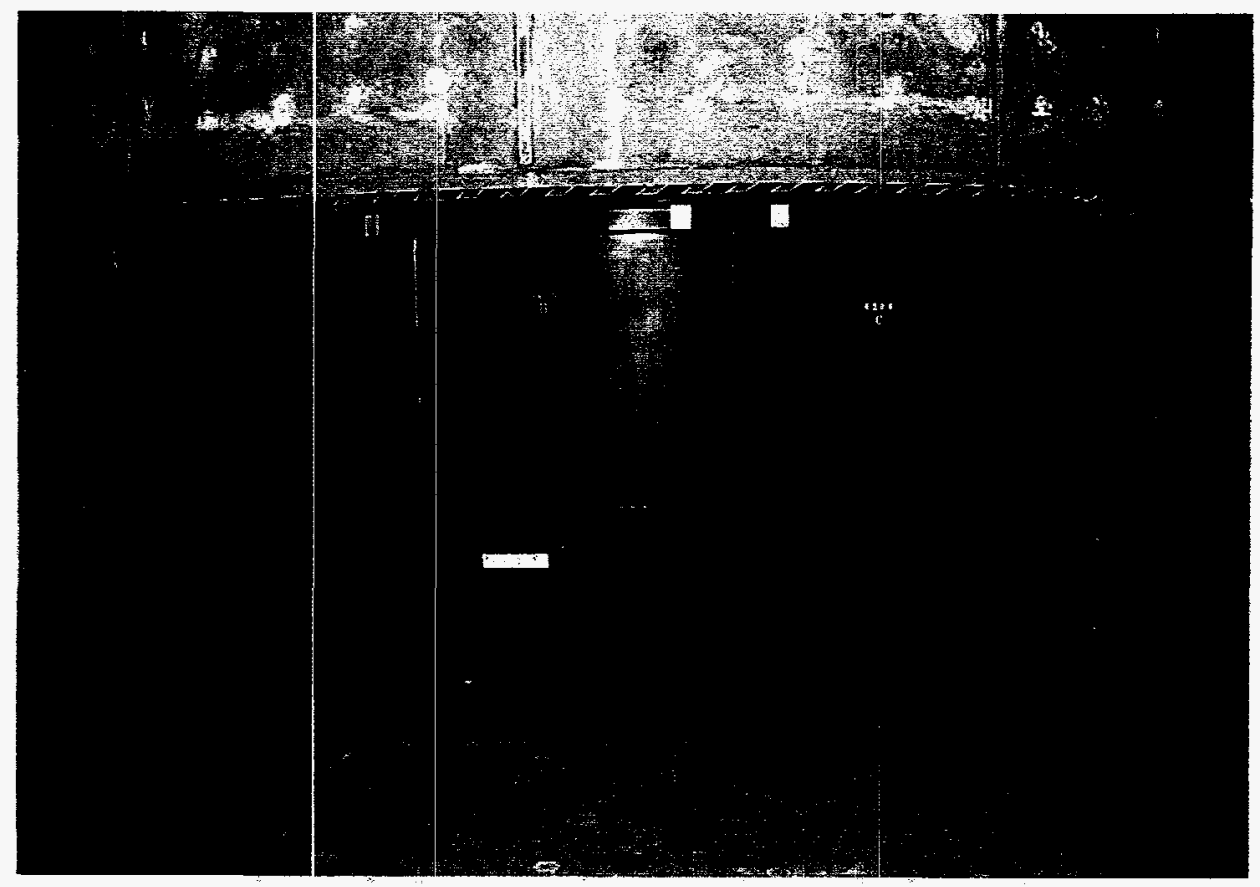

Figure 6.19 Low-Dose Face at Completion of Attenuator Lead Removal (ANL Negative \#22891K, Frame \#17) 


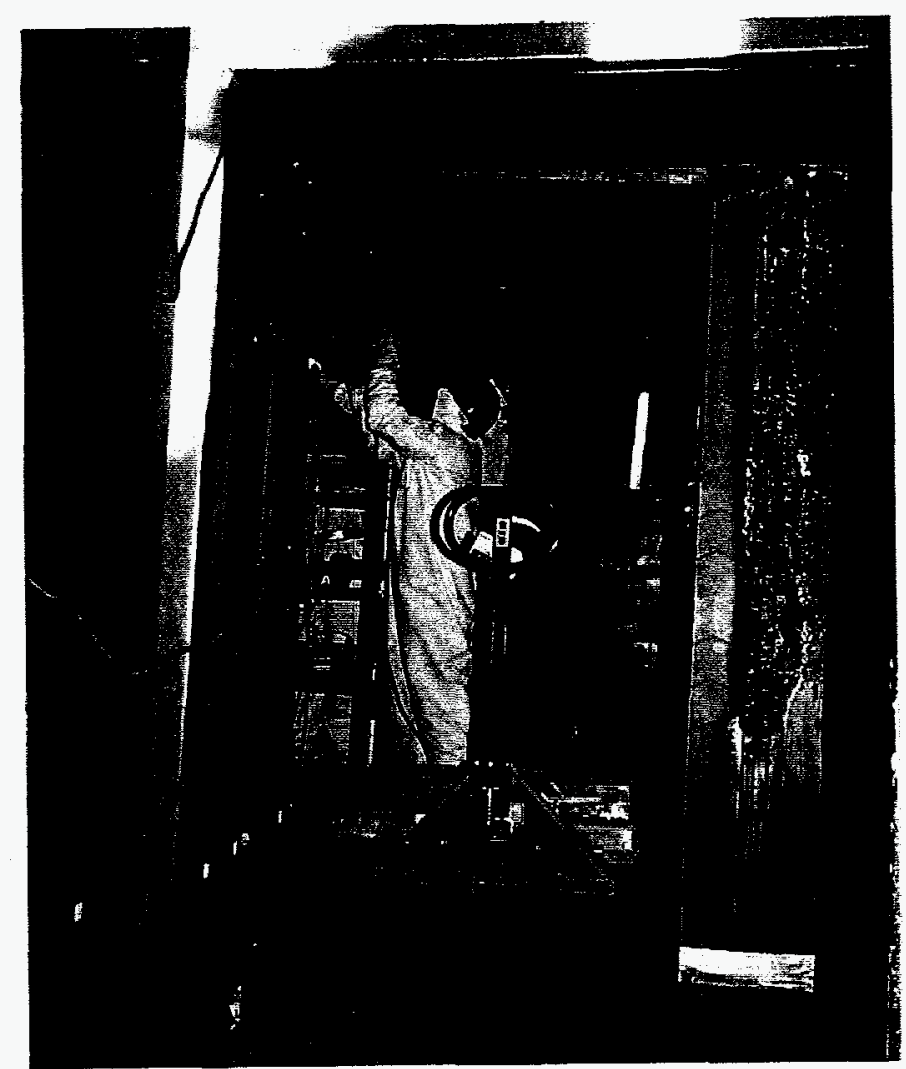

Figure 6.20 Technicians Removing Ceiling Lead from High-Dose Room (ANL Negative \#22760K, Frame \#10A)

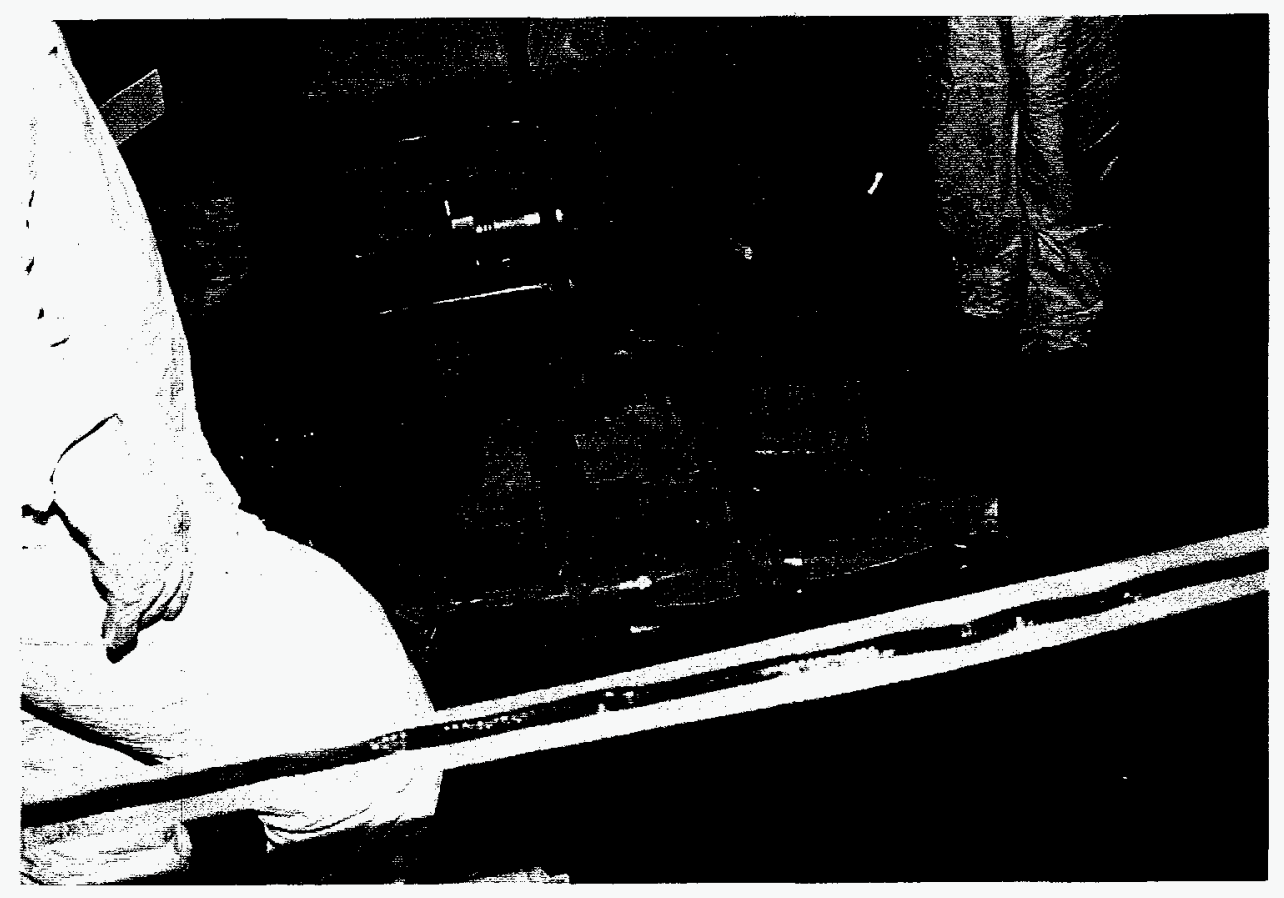

Figure 6.21 Ceiling Tiles Staged for Survey (ANL Negative \#22760K, Frame \#11A) 


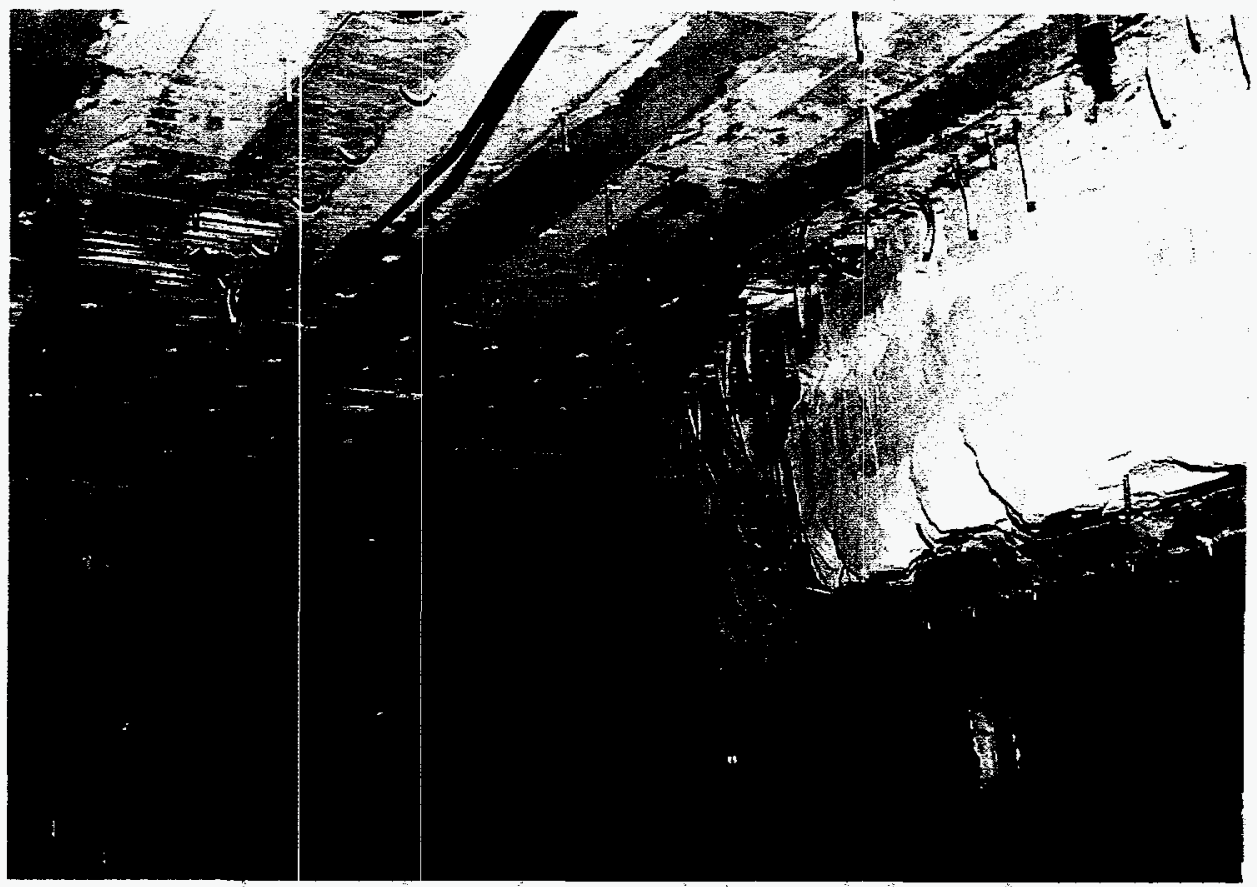

Figure 6.22 Borobauxite Concrete Ceiling in High-Dose Room Prior to Removal (ANL Negative \#22891K, Frame \#11)

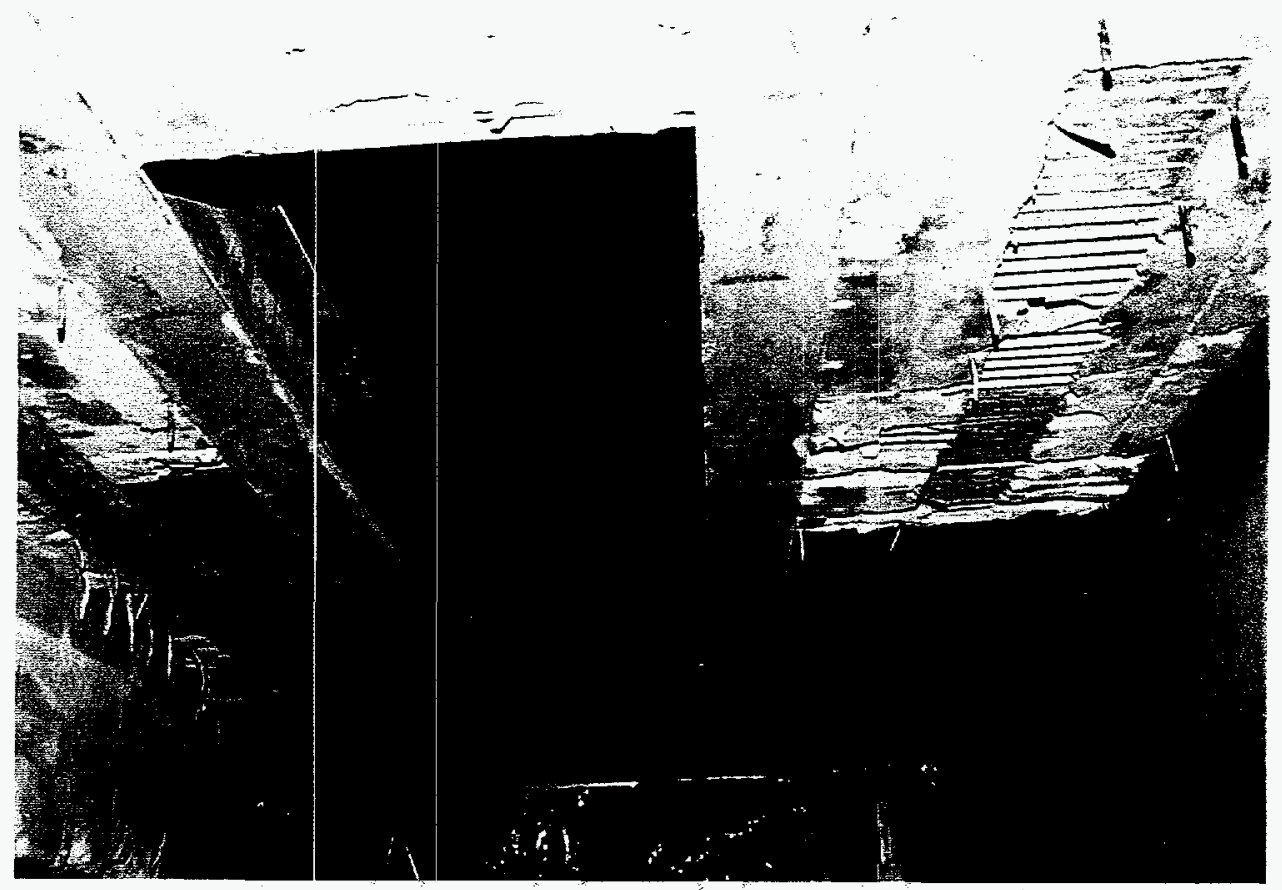

Figure 6.2.3 High-Dose Room Ceiling Partially Removed (ANL Negative \#22981K, Frame \#13) 


\subsubsection{Reactor Area Demolition}

Reactor area demolition encompassed removing equipment and components in the vicinity of the reactor (the area between the high- and low-dose rooms) including the control rod drive system, piping and wiring, the reactor tank and internals, the graphite reflector, and the steel shell. A description of each phase of reactor area demolition is provided below.

\subsubsection{Shielded Floor Plug Removal}

Above the reactor were five shielded floor plugs that were removed to provide access to the top of the reactor and steel shell. The 10 ton $(9.1 \mathrm{MT})$ overhead crane was used to remove the plugs and place them outside the JANUS Reactor facility, where they were stripped of lead-based paint and repainted (see Figures 6.24 and 6.25). This task was accomplished on March 25, 1997.

\subsubsection{Containment Installation}

A containment tent was constructed over the opening to the reactor area allowing dismantlement of potentially contaminated equipment and piping to be done inside (see Figures 6.26 and 6.27). The containment was ventilated with a portable HEPA ventilation system to control potential airborne emissions. This task was completed between February 27, 1997 and March 3, 1997.

\subsubsection{Piping and Equipment Removal from Above the Reactor}

After constructing the containment tent, the piping, equipment and wiring above the reactor was disassembled using hand tools and electric saws. All material was removed and packaged as lowlevel radioactive waste. This task was accomplished between March 26, 1997 and April 23, 1997. Figures 6.28 and 6.29 show the dismantlement of equipment and systems above the reactor.

\subsubsection{Reactor Shield Plug Removal}

After removal of all piping and equipment that might interfere with the removal of the reactor shield plug, the hold-down bolts were removed and the shield plug was rigged to the 10 ton (9.1 MT) overhead crane. The plug was then raised to allow health physics technicians to perform radiological surveys of loose contamination and to determine dose rates around the top of the open reactor tank. Upon completion of the surveys, the shield plug was packaged in a special oversized waste bin as low-level radioactive waste. This task was completed on April 24, 1997. The removal of the reactor shield plug is shown in Figures 6.30 and 6.31. 


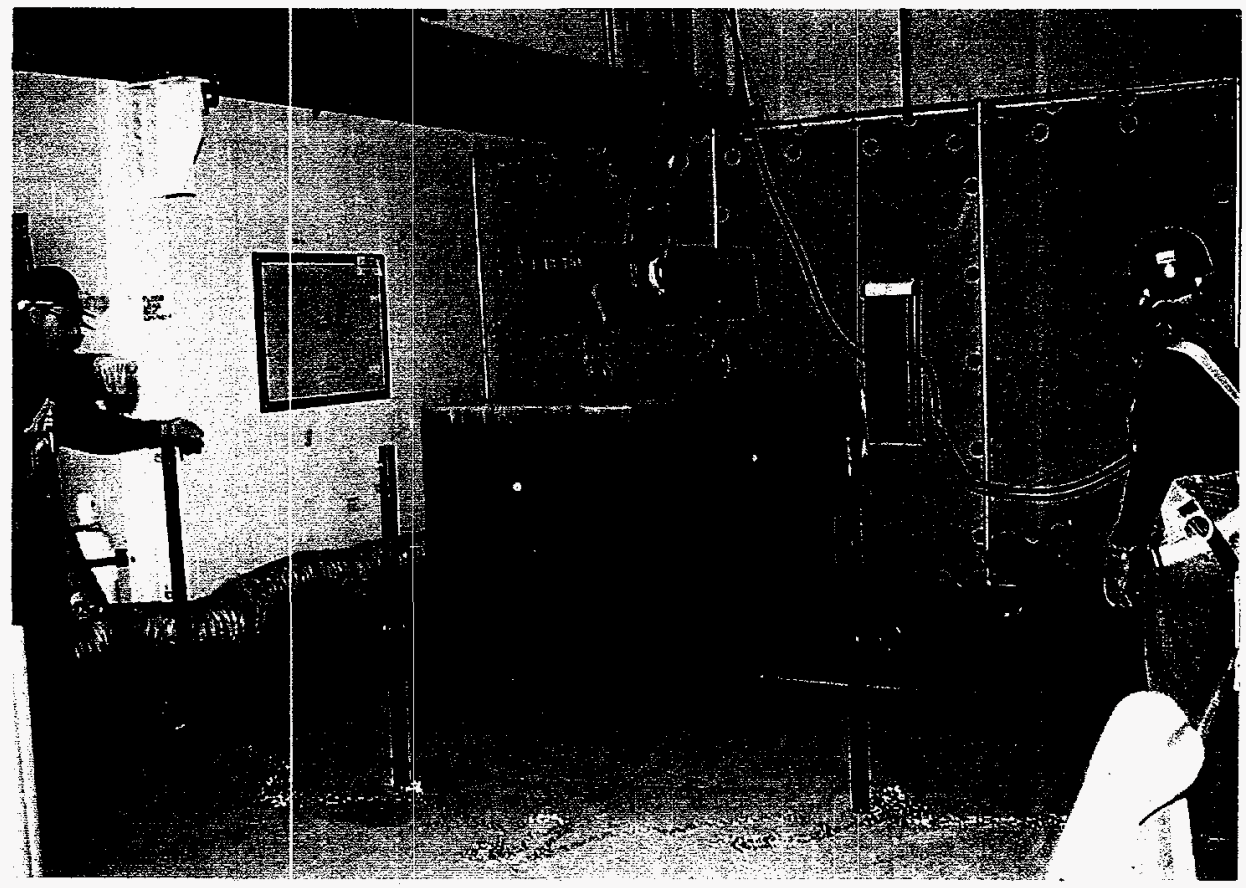

Figure 6.24 Reactor Area Floor Plug Being Removed (ANL Negative \#22891K, Frame \#21)

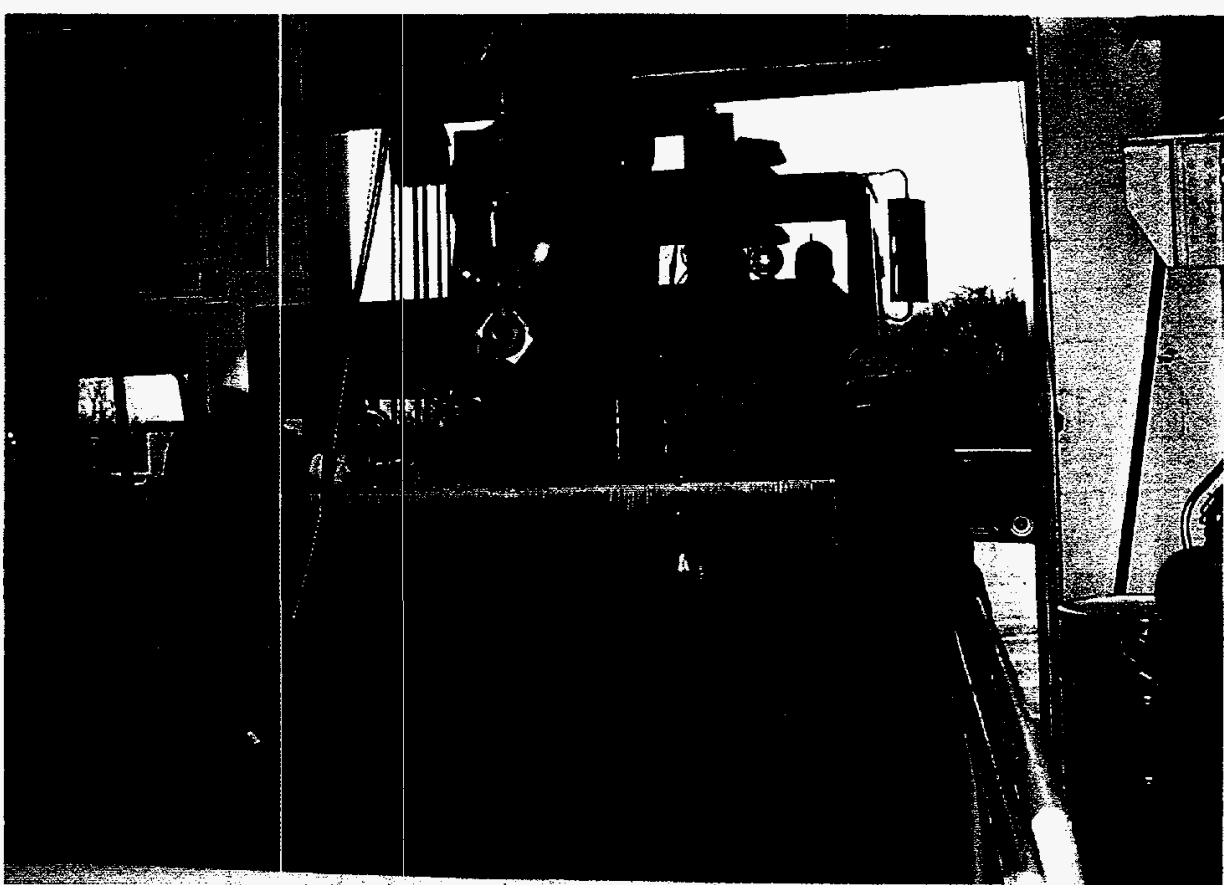

Figure 6.25 Preparing to Move Floor Plug Outside for Storage (ANL Negative \#22891, Frame \#24) 


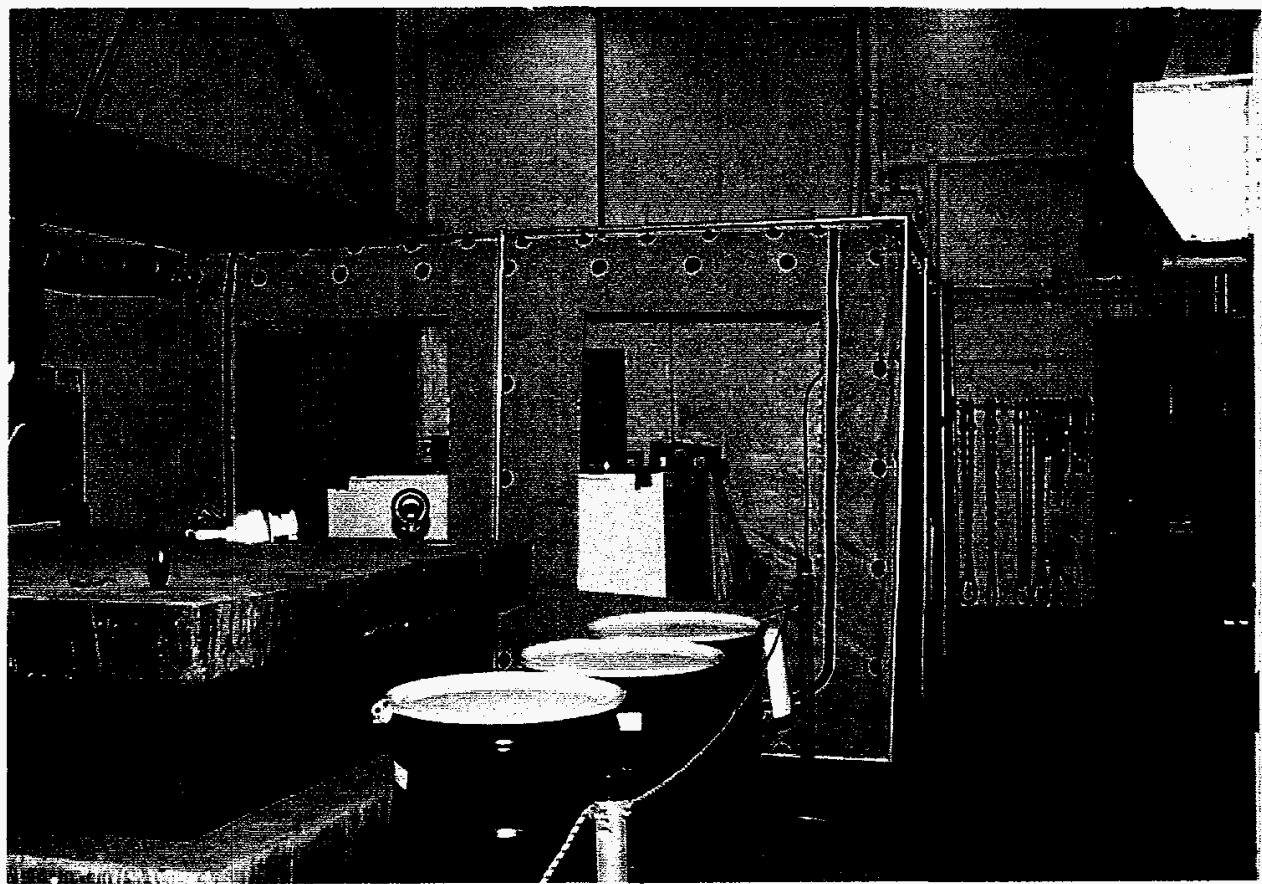

Figure 6.26 Containment Tent Over High-Dose Room Floor Opening (ANL Negative \#22846K, Frame \#10A)

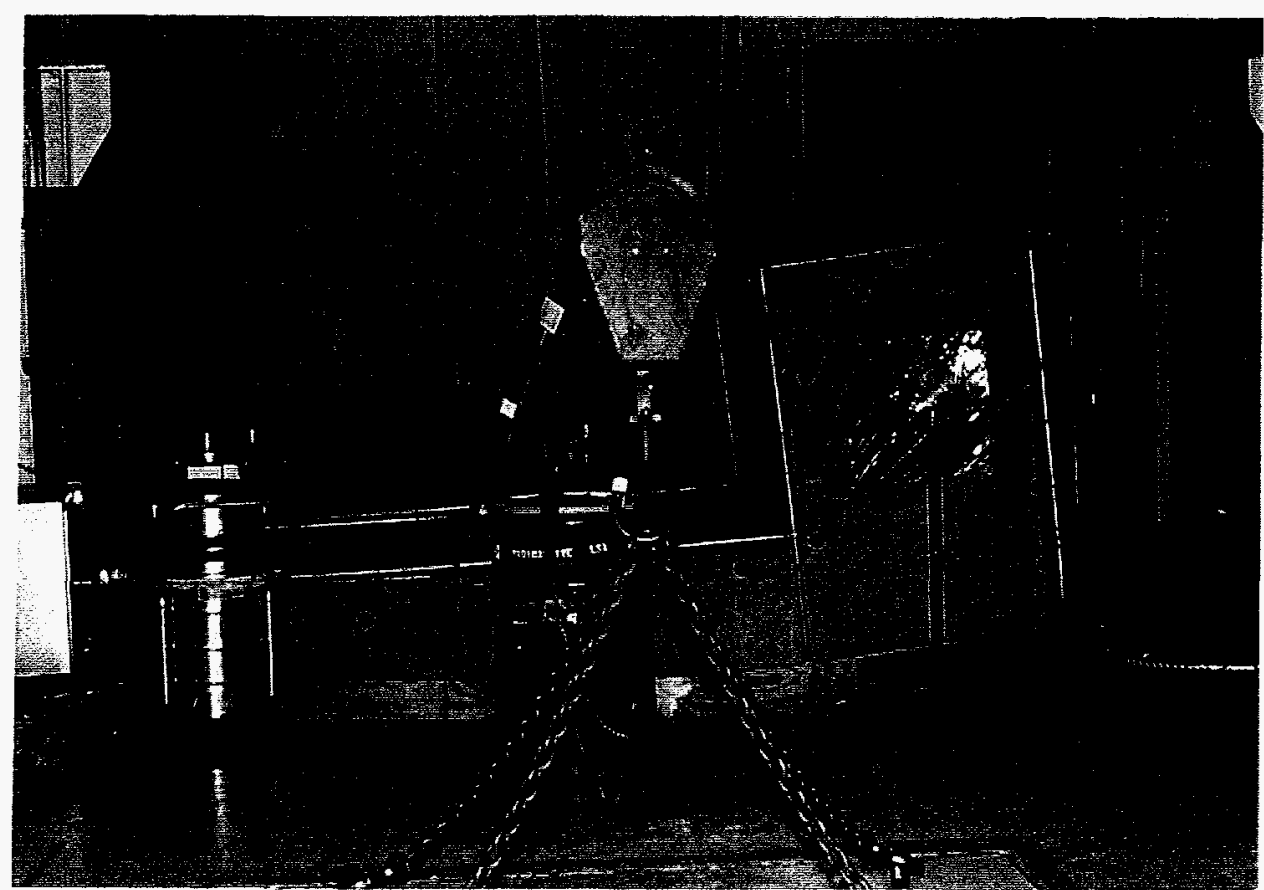

Figure 6.27 Containment Set-Up Over Reactor Opening (ANL Negative \#23322K, Frame \#22) 


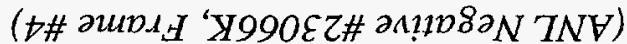

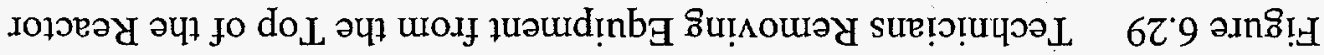

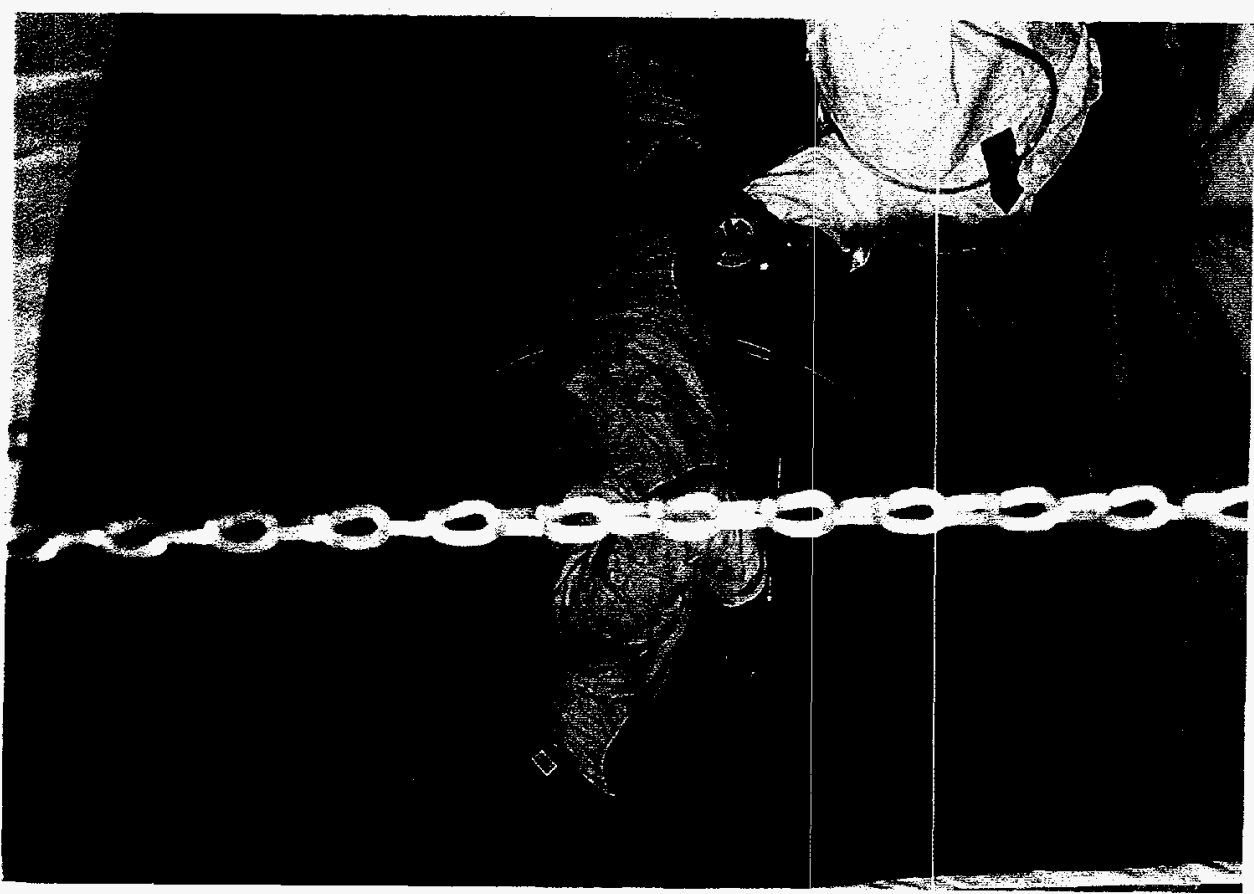

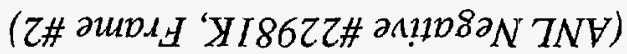

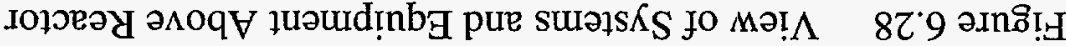

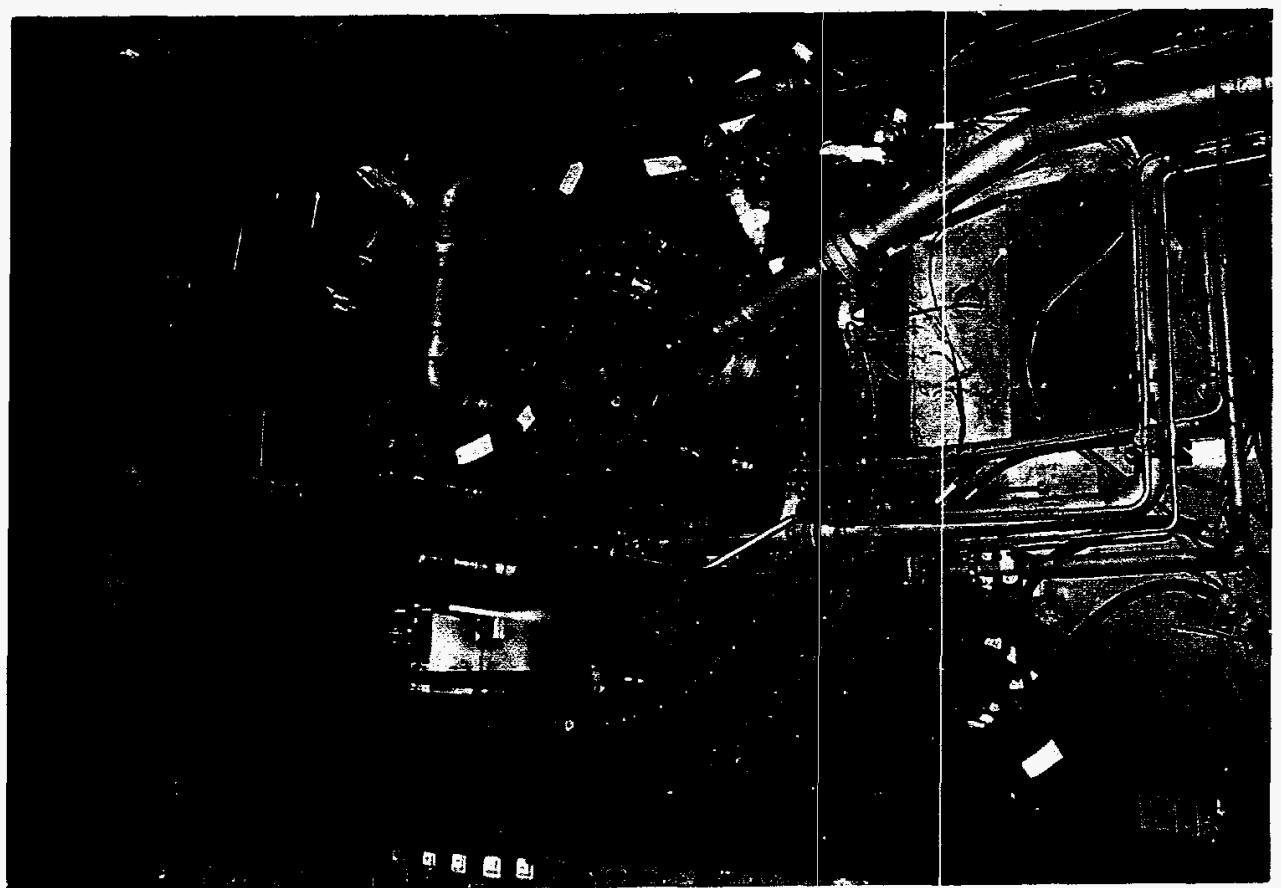




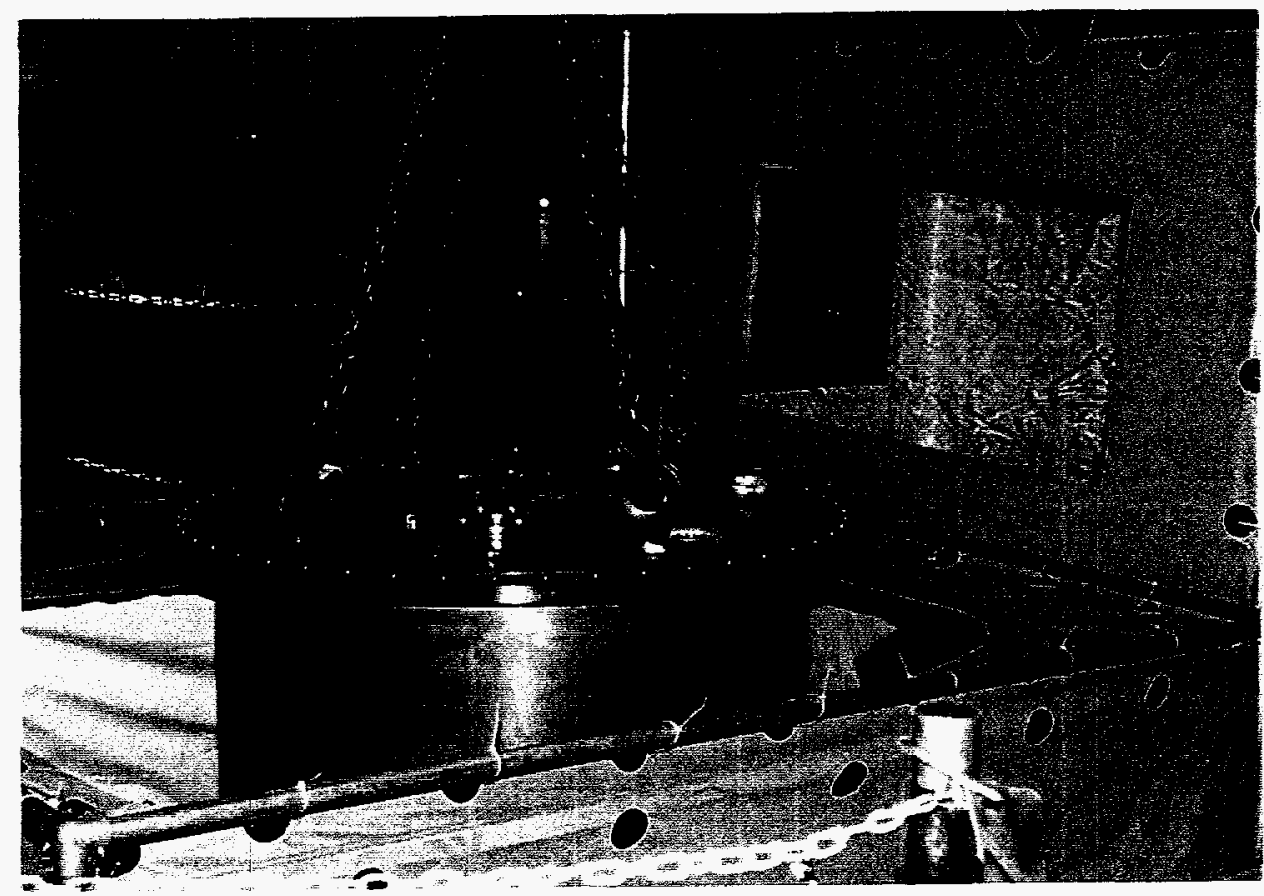

Figure 6.30 Reactor Shield Plug Being Lifted from Containment (ANL Negative \#23066K, Frame \#18)

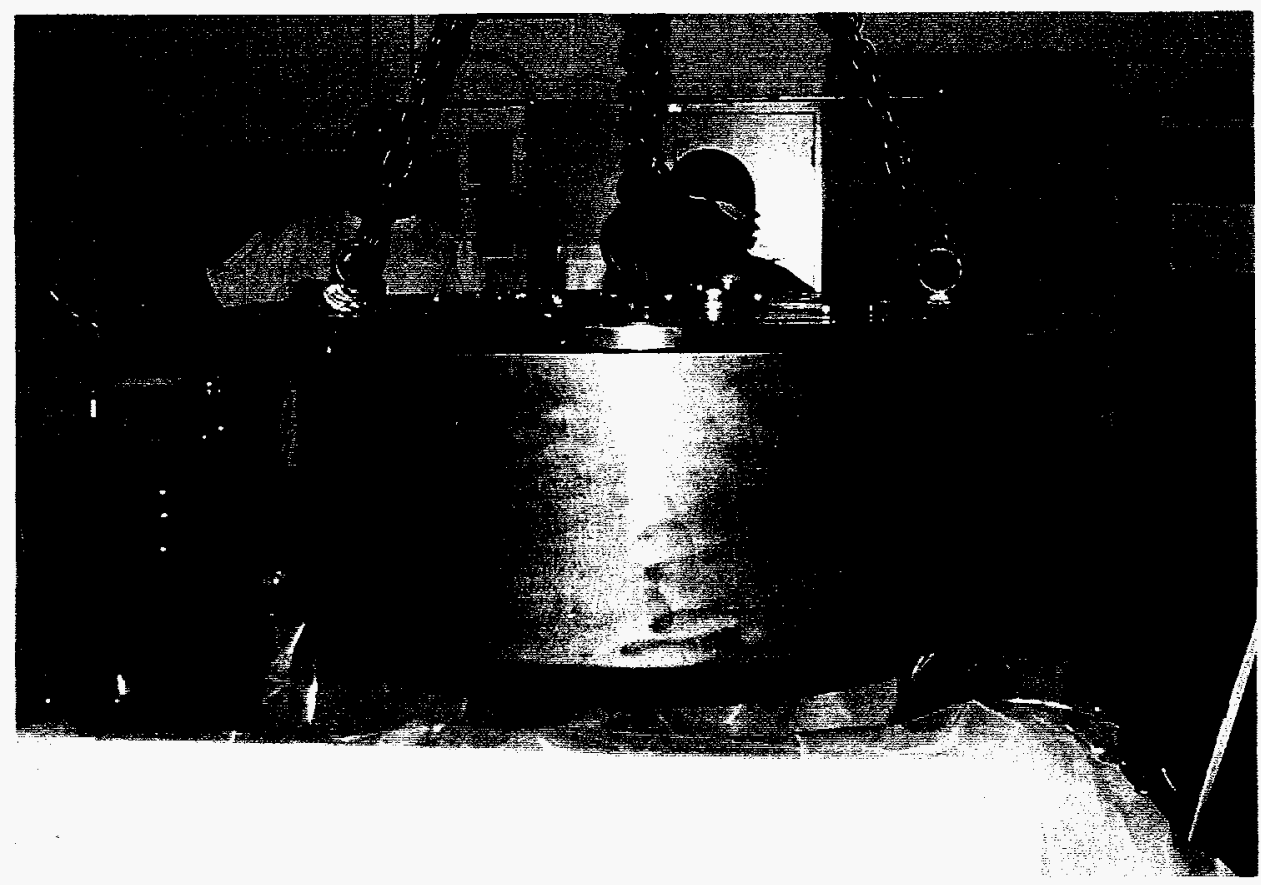

Figure 6.31 Loading Reactor Shield Plug into Waste Container (ANL Negative \#23066K, Frame \#23) 


\subsubsection{Attenuator Tank Removal}

The attenuator tank, located on the high-dose side of the reactor core, consisted of a sealed aluminum tank filled with graphite. This tank exhibited the highest dose rates encountered $(400 \mathrm{mR} / \mathrm{hr}$ ( $4 \mathrm{mSv} / \mathrm{hr}$ )) during the entire D)\&D of the JANUS Reactor facility. It was removed from the reactor and packaged for disposal as low-level radioactive waste. This work was performed on April 28, 1997.

\subsubsection{Reactor Internals Removal}

After the reactor tank was removed from the steel shell and placed inside a contamination-control area, the reactor internals were removed from the tank, size reduced and packaged as low-level radioactive waste (see Figures 6.32 and 6.33). This work was performed on April 28, 1997.

\subsubsection{Rabbit Tube Assembly Removal}

Prior to removal of the reactor tank, it was necessary to disconnect the rabbit tube assembly from the reactor tank and remove it. The rabbit tube was mechanically disassembled and removed from its access tube in the biological shield. Portions of the rabbit tube assembly which were located close to the reactor were packaged as low-level radioactive waste. The shield plug and outside sections of the rabbit tube were surveyed and disposed of as clean scrap. The rabbit tube assembly was removed between April 9,1997 and April 10, 1997. Figures 6.34 and 6.35 show rabbit tube removal operations.

\subsubsection{Reactor Tank Removal}

This activity involved lifting the aluminum reactor tank out of the steel shell and the surrounding graphite reflector, and transferring it to a contamination-control area for size reduction and packaging. In order to lift the off-set load caused by the lead and graphite-stepped system attached to one side of the reactor tank, a special lifting rig was purchased. The reactor tank was rigged to the 10 ton (9.1 MT) overhead crane and moved to the lay-down area on April 25, 1997. Size reduction and packaging operations were completed on April 29, 1997. Figures 6.36 and 6.37 show the removal of the reactor tank. 
JANUS D\&D Project

Final Report

Page 53 of 111

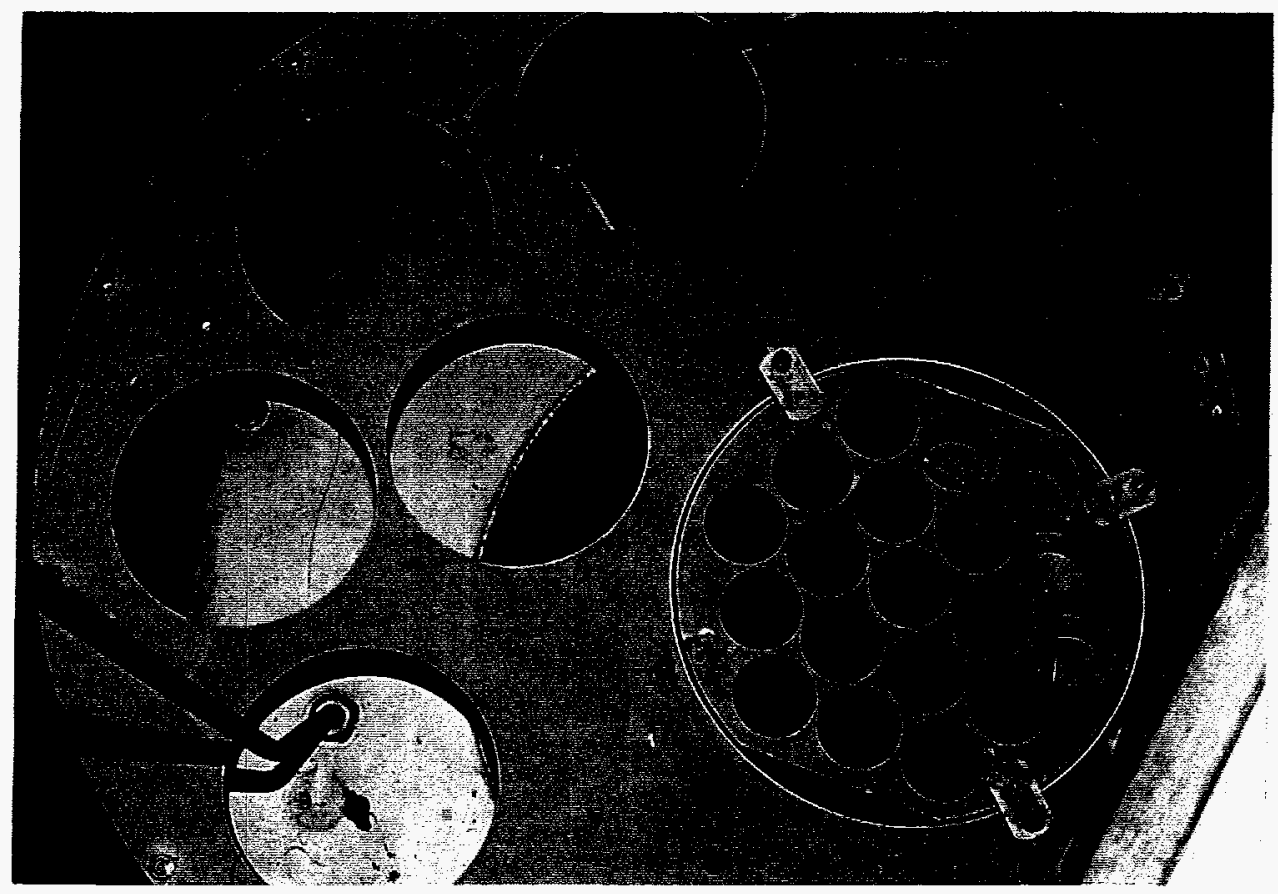

Figure 6.32 View of Reactor Internals Prior to Removal (ANL Negative \#23071K, Frame \#3)

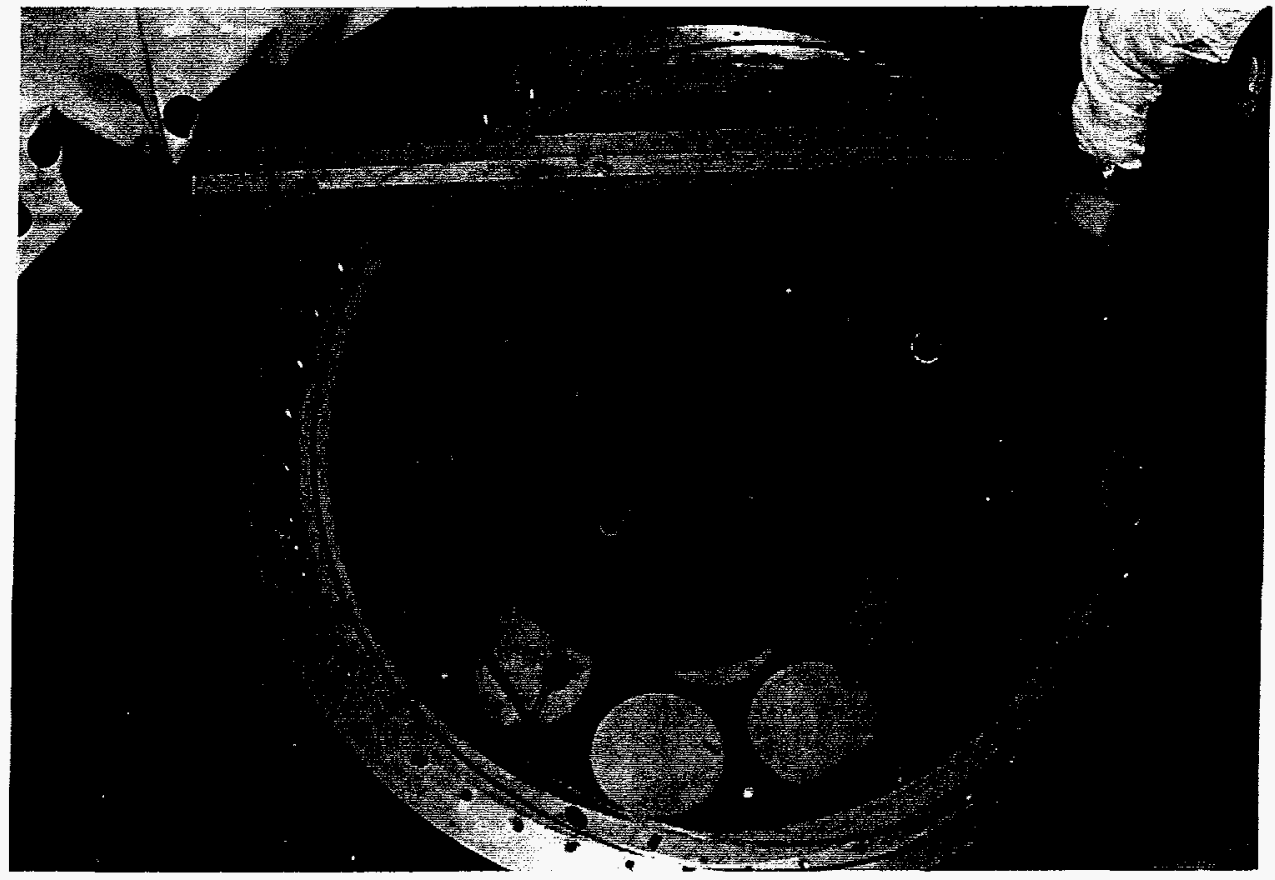

Figure 6.33 Technician Using Long-Handled Socket During Removal of Reactor Internals (ANL Negative \#23071K, Frame \#5) 


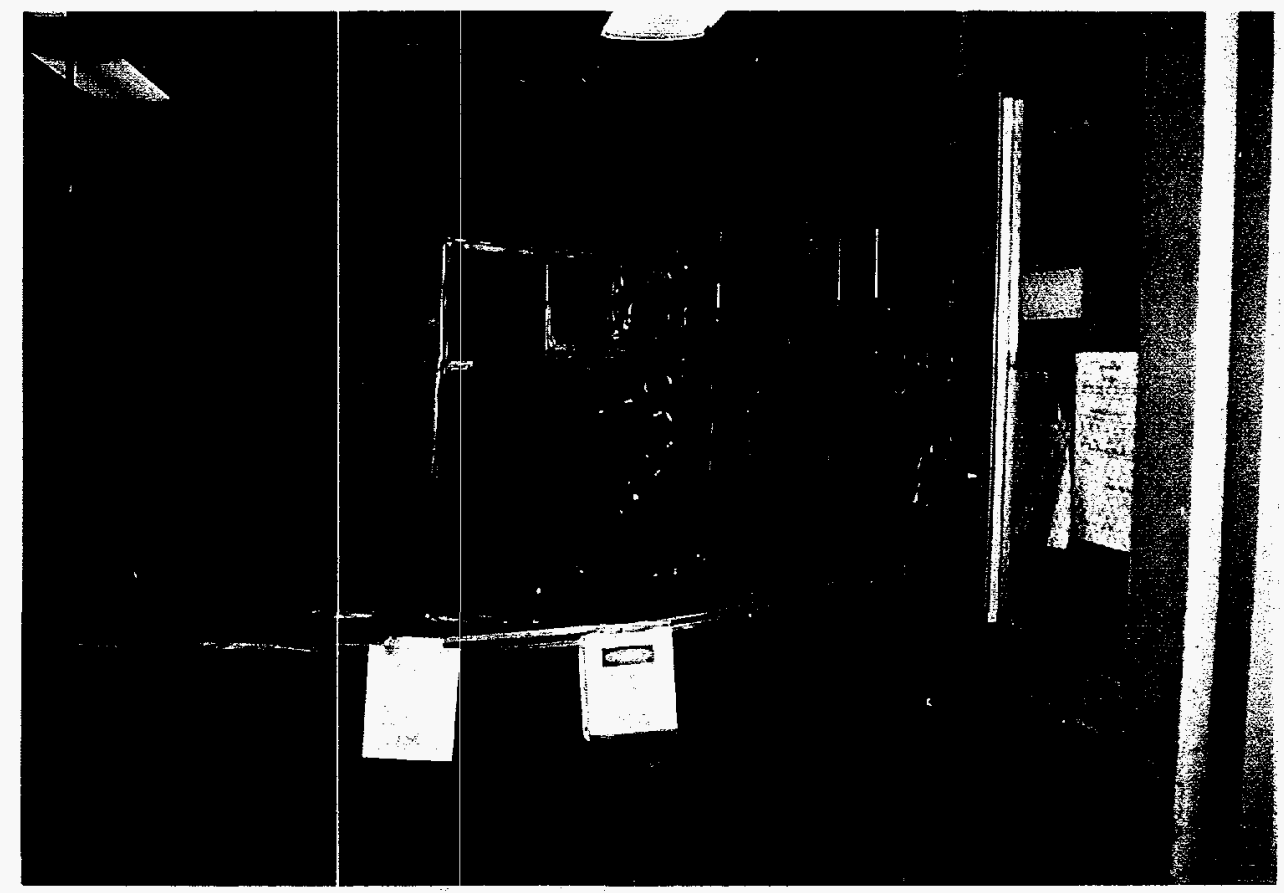

Figure 6.34 Technicians Installing Contamination Controls Prior to Rabbit Tube Removal (ANL Negative \#22981, Frame \#16)

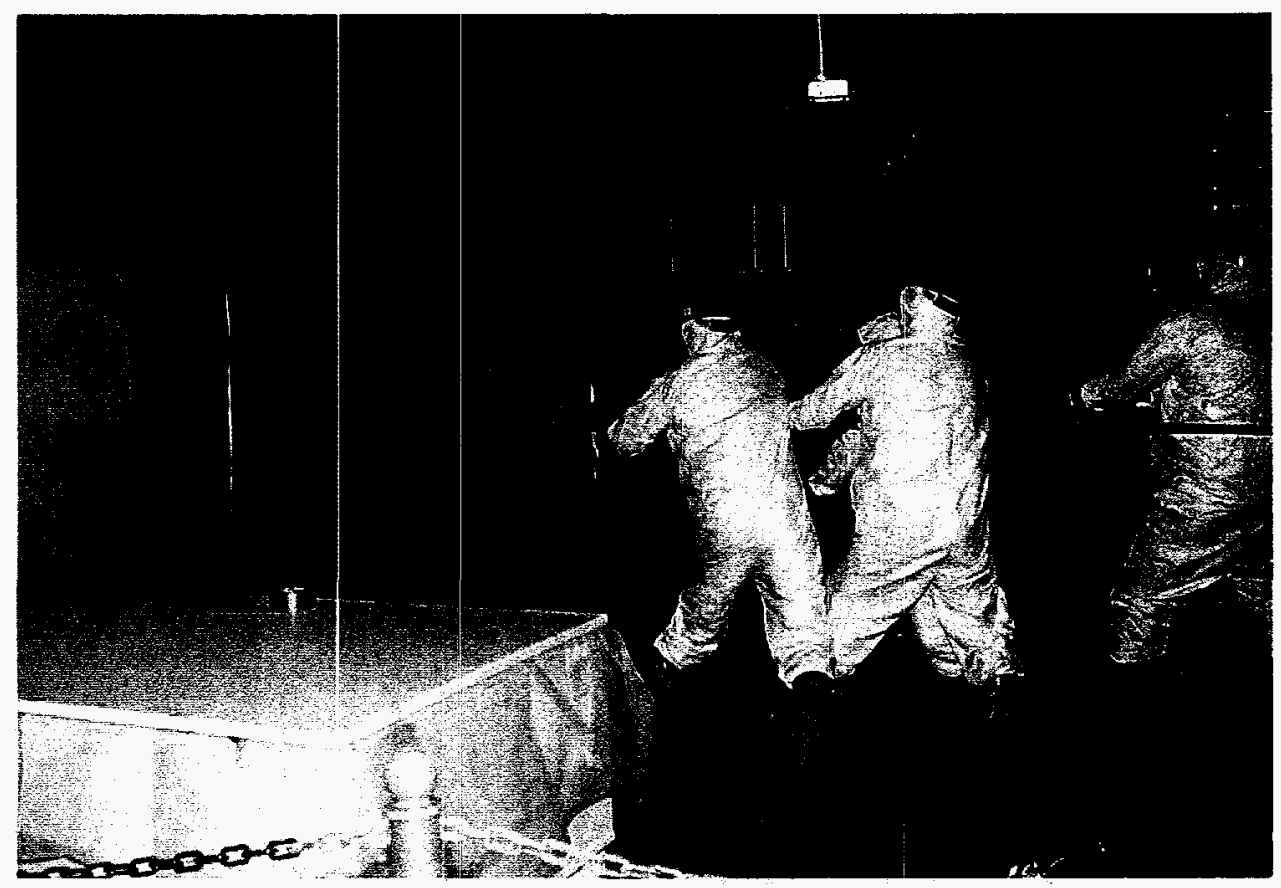

Figure 6.35 Technicians Removing Rabbit Tube Shield Plug (ANL Negative \#22981K, Frame \#23A) 


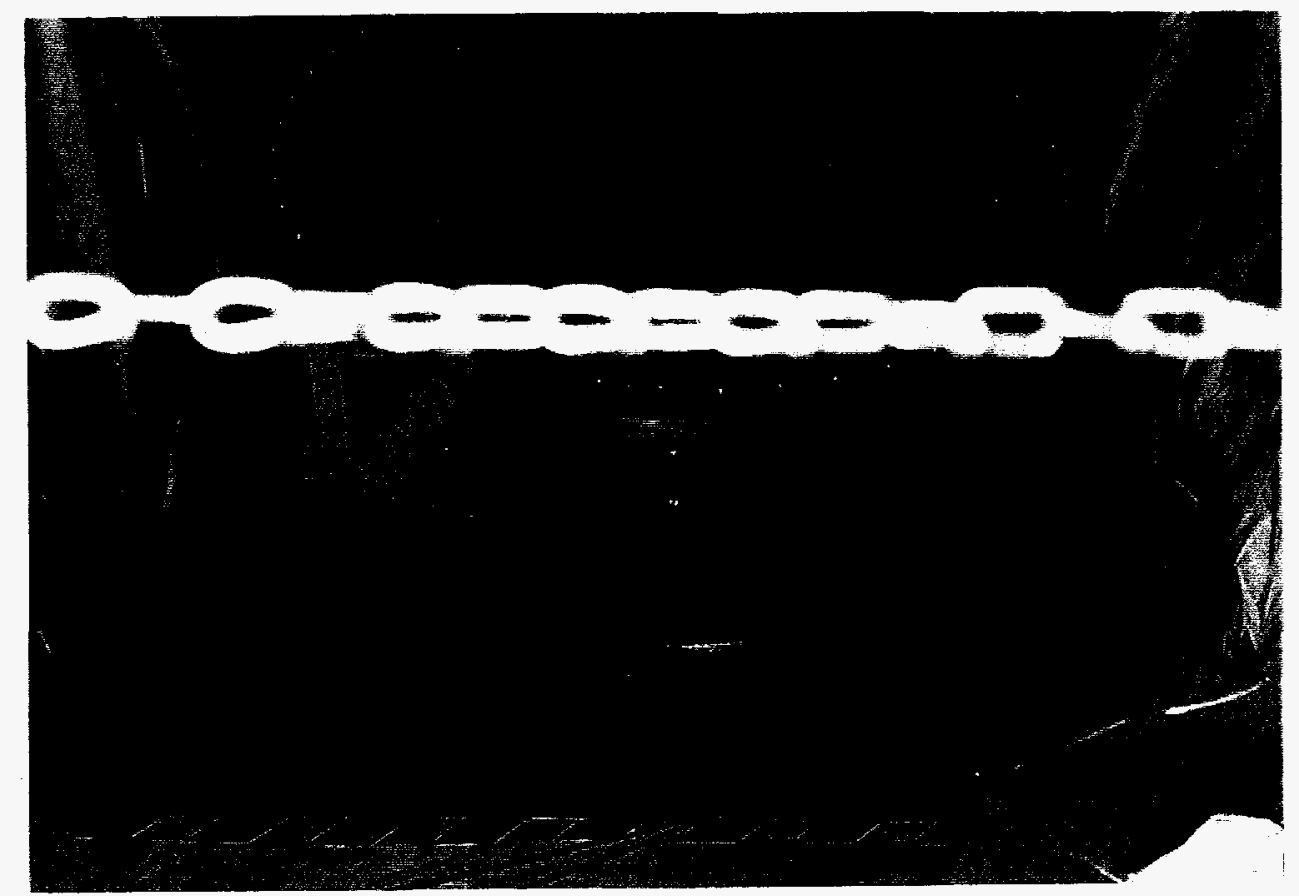

Figure 6.36 Reactor Tank Being Lifted From Reactor Cavity (ANL Negative \#23071K, Frame \#19)

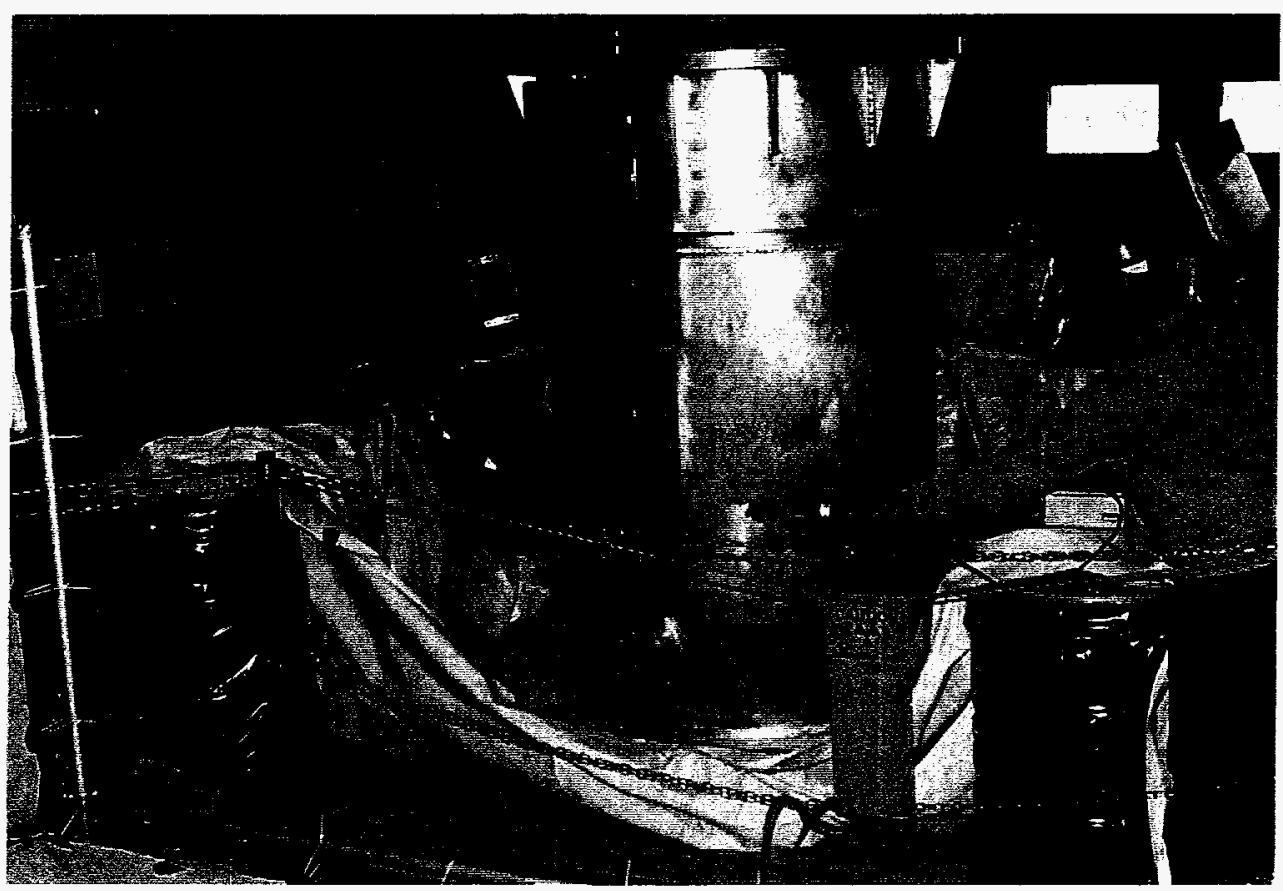

Figure 6.37 Technician Performing Radiation Surveys on Reactor Tank in Lay-Down Area (ANL Negative \#23072K, Frame \#16) 


\subsubsection{Graphite Removal}

After removal of the reactor tank, the graphite reflector blocks were exposed. The void area where the reactor tank had been sitting was classified as a permit-required confined space requiring air monitoring and personnel retrieval during entry. Removal of the graphite began at the top of the void left by the reactor tank and progressed working down. The graphite was placed into 55 gal (208 1) drums and lifted out with the 10 ton (9.1 MT) overhead crane. Waste was packaged for disposal into B-12 steel bins. After the height of graphite had been reduced to below the top edge of the low-dose window, the window cover was removed allowing graphite removal to continue from the low-dose room. After the opening was enlarged, the area was reclassified as non-permitrequired confined space. This work started on May 8, 1997 and finished on June 3, 1997. Figures 6.38 and 6.39 show graphite removal.

\subsubsection{Steel Shell Removal}

The steel shell surrounded the graphite region of the reactor and, when the reactor was in place, it had provided a gas-tight enclosure. The steel shell was made of 0.5 in $(1.27 \mathrm{~cm})$ thick steel; to reduce neutron activation of the steel and surrounding concrete, a 0.125 in $(0.318 \mathrm{~cm})$ thick layer of boral had been riveted to the entire interior surface. During removal, the boral was stripped from the inside surface using pry bars, folded up and placed in low-level radioactive waste bins for disposal. The steel shell was then cut into pieces with a plasma arc torch and abrasive cut-off saw, and packaged as low-level radioactive waste. This activity started on May 19, 1997 and finished on September 9, 1997. Figures 6.40 and 6.41 show the removal of the steel shell.

\subsubsection{High- and Low-Dose Shutter System Removal}

The high- and low-dose shutter: systems were used during reactor operation to protect personnel from neutron and gamma radiation during entry into the dose rooms. The low-dose shutters, constructed of 10 in $(25.4 \mathrm{~cm})$ thick interlocking steel-encased ferrophosphate concrete blocks, were operated (raised or lowered) from the reactor control room by pneumatic cylinders. When the shutters were in the down position, they rested upon shutter pedestals of the same construction. The high-dose shutters were 28 in $(71.12 \mathrm{~cm})$ thick interlocking steel-encased lead and polyethylene blocks that sat upon pedestals of similar construction. The high-dose shutters were also operated from the control room by pneumatic cylinders. The following sections describe the removal of the shutter systems components. 


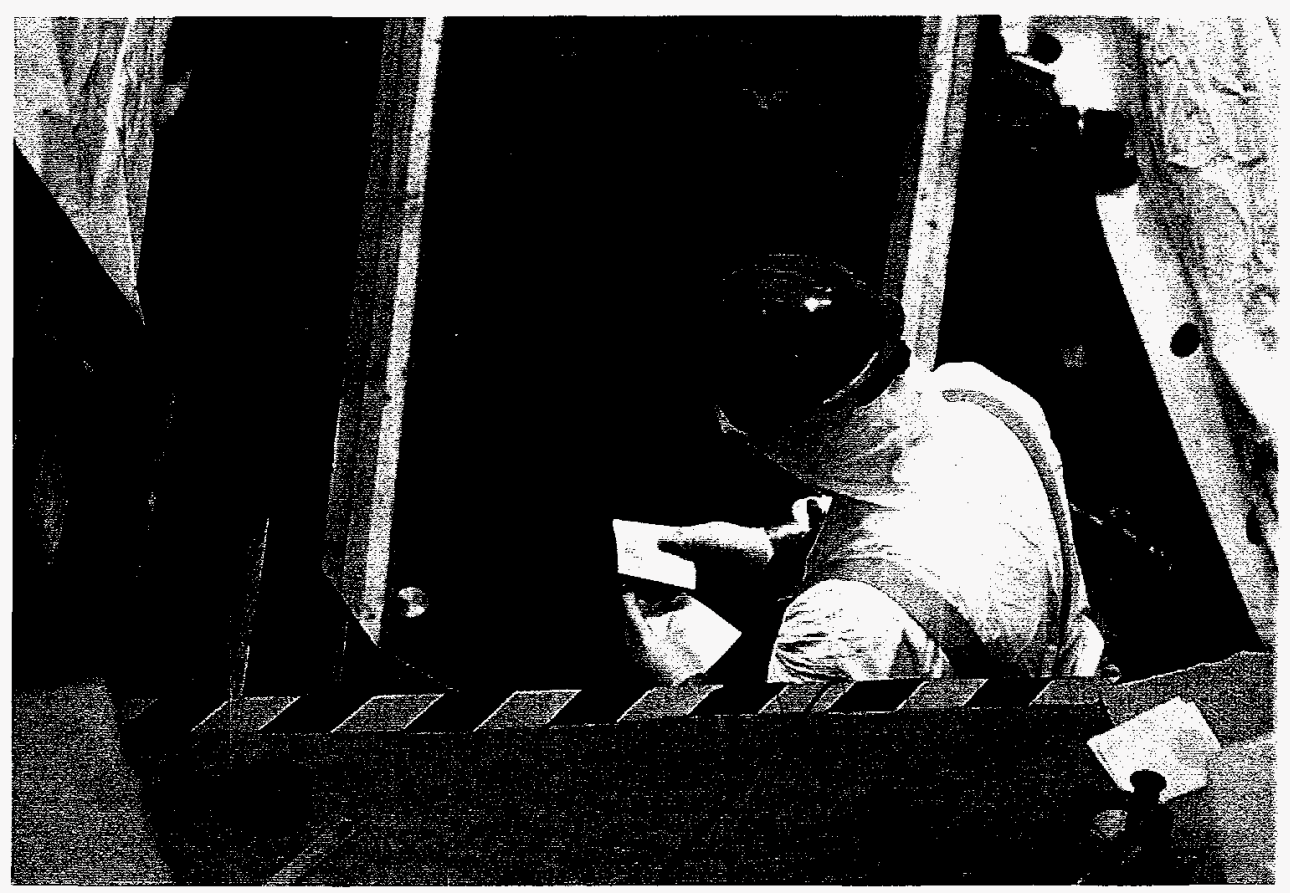

Figure 6.38 Health Physics Technician Surveying Graphite Prior to Removal (ANL Negative \#23072K, Frame \#9)

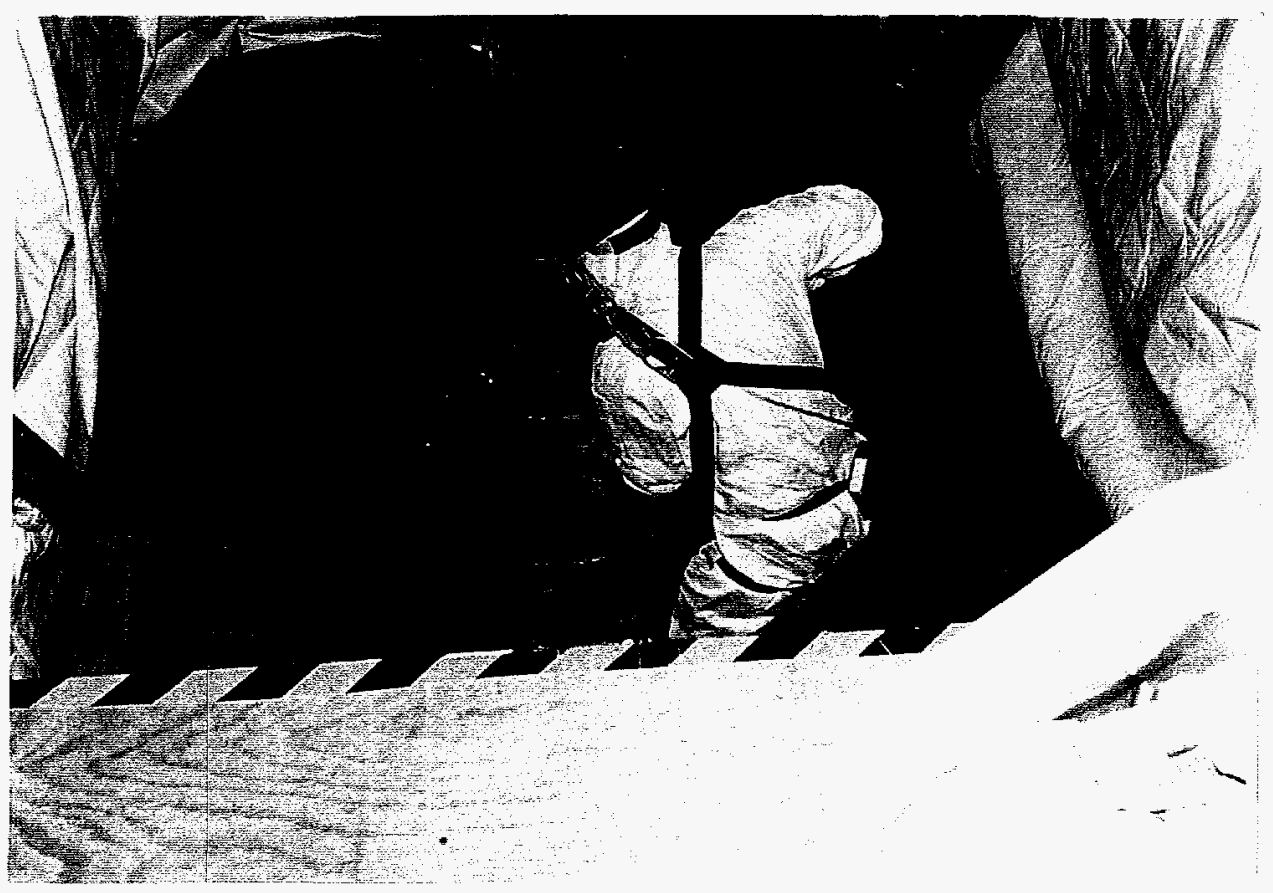

Figure 6.39 Technician Removing Graphite from Reactor Cavity (ANL Negative \#23153K, Frame \#11A) 


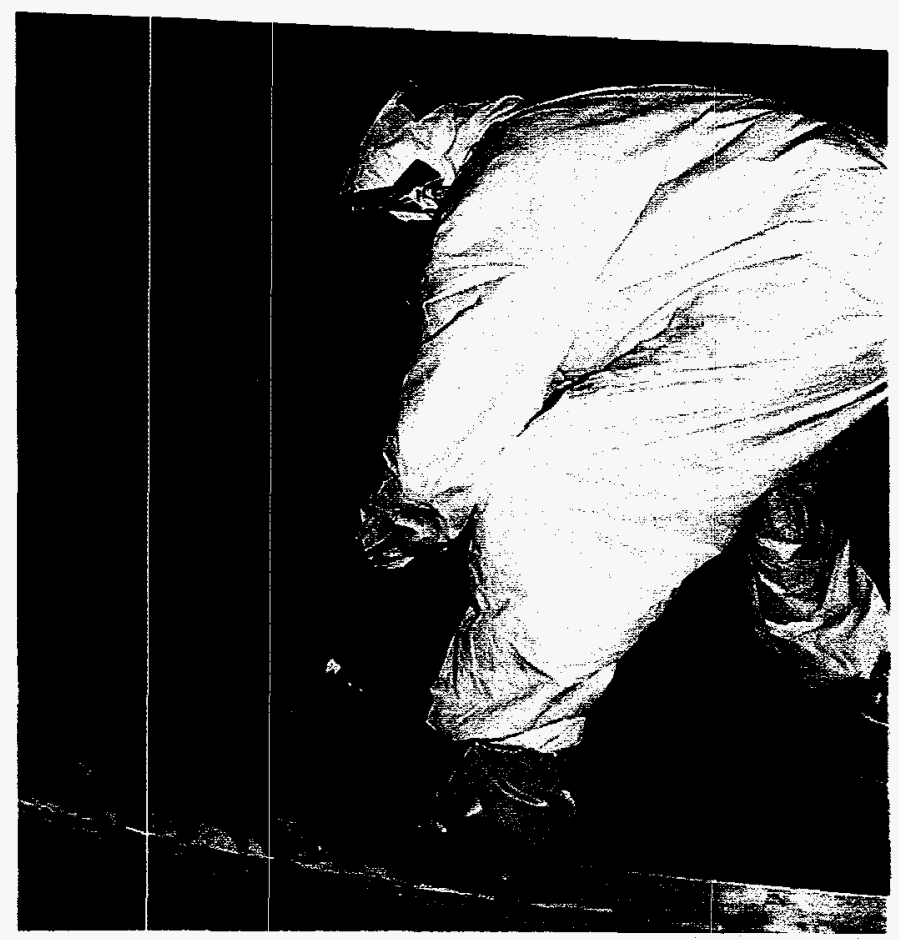

Figure 6.40 Technician Size Reducing a Section of Steel Shell for Packaging (ANL Negative \#23407K, Frame \#3A)

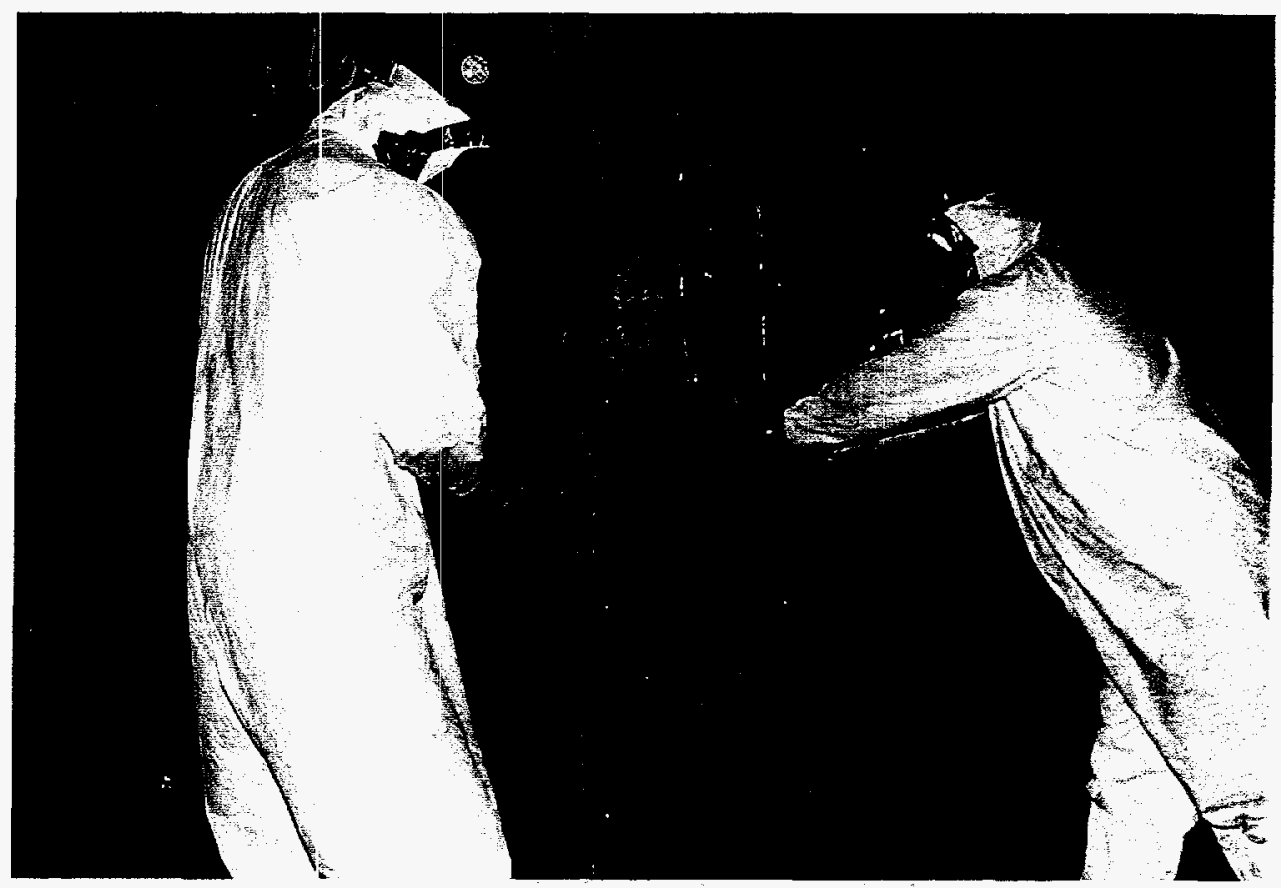

Figure 6.41 Technicians Removing a Section of Steel Shell (ANL Negative \#23407K, Frame \#2A) 


\subsubsection{High-Dose Shutter Drive Removal}

The high-dose shutter drive consisted of three large pneumatic cylinders mounted on a support stand in the high bay, two air receiver tanks and associated piping in the HEPA filter room and associated electrical controls. To remove the shutter drive, the electrical and air systems were LO/TO, and the associated piping and electrical controls were removed. The cylinders were attached to the high-dose shutters by a steel shaft that penetrated the shielded floor plugs. Once the cylinder shafts were disconnected from the shutters, the cylinders were removed from the stand, surveyed and released as clean scrap. The air receivers were isolated and disconnected from the building air system and released as clean scrap. This task was performed between January 22, 1997 and January 28, 1997. Figures 6.42 and 6.43 show removal of the shutter drives.

\subsubsection{Low-Dose Shutter Drive Removal}

The low-dose shutter drive consisted of three pneumatic cylinders mounted in special shielded floor plugs below the high bay. The air receiver and electrical controls for these cylinders were located in the reactor equipment room. LO/TO was performed on the electrical and air systems prior to removal. The cylinder shafts were disconnected from the shutters, and the cylinders were rigged to the 10 ton (9.1 MT) overhead crane, removed, disassembled, and packaged for disposal as low-level radioactive waste. This work was performed between January 22, 1997 to March 24, 1997.

\subsubsection{High-Dose Shutter and Pedestal Removal}

The high-dose shutters were left in place until the graphite was removed to provide gamma shielding for personnel working in the high-dose room. The shutters and pedestals were rigged to the 10 ton (9.1 MT) overhead crane and transferred to a containment, where activated lead and polyethylene from inside the steel casing were removed. The steel casing and polyethylene were disposed of as low-level radioactive waste, and the lead was packaged as mixed waste. The grouting of voids behind the shutter guides and pedestals prevented direct removal of the high-dose shutter pedestals with the crane. Before they could be lifted free, the shutter guides had to be dismantled in place and the grout removed from around the pedestals. This work started on June 6, 1997 and finished on September 9, 1997. Figures 6.44 and 6.45 describe this work.

\subsubsection{Low-Dose Shutter and Pedestal Removal}

As with the high-dose shutters, the low-dose shutters were also left in place until removal of the graphite was started to provide gamma shielding for personnel working in the low-dose room. The shutters and pedestals were rigged to the 10 ton $(9.1 \mathrm{MT})$ overhead crane and transferred to a lay-down area for survey and release. The low-dose shutters were disposed of as clean scrap. This work started on May 29, 1997 and completed on June 2, 1997. Figures 6.46 and 6.47 show removal of the low-dose shutters and pedestals. 


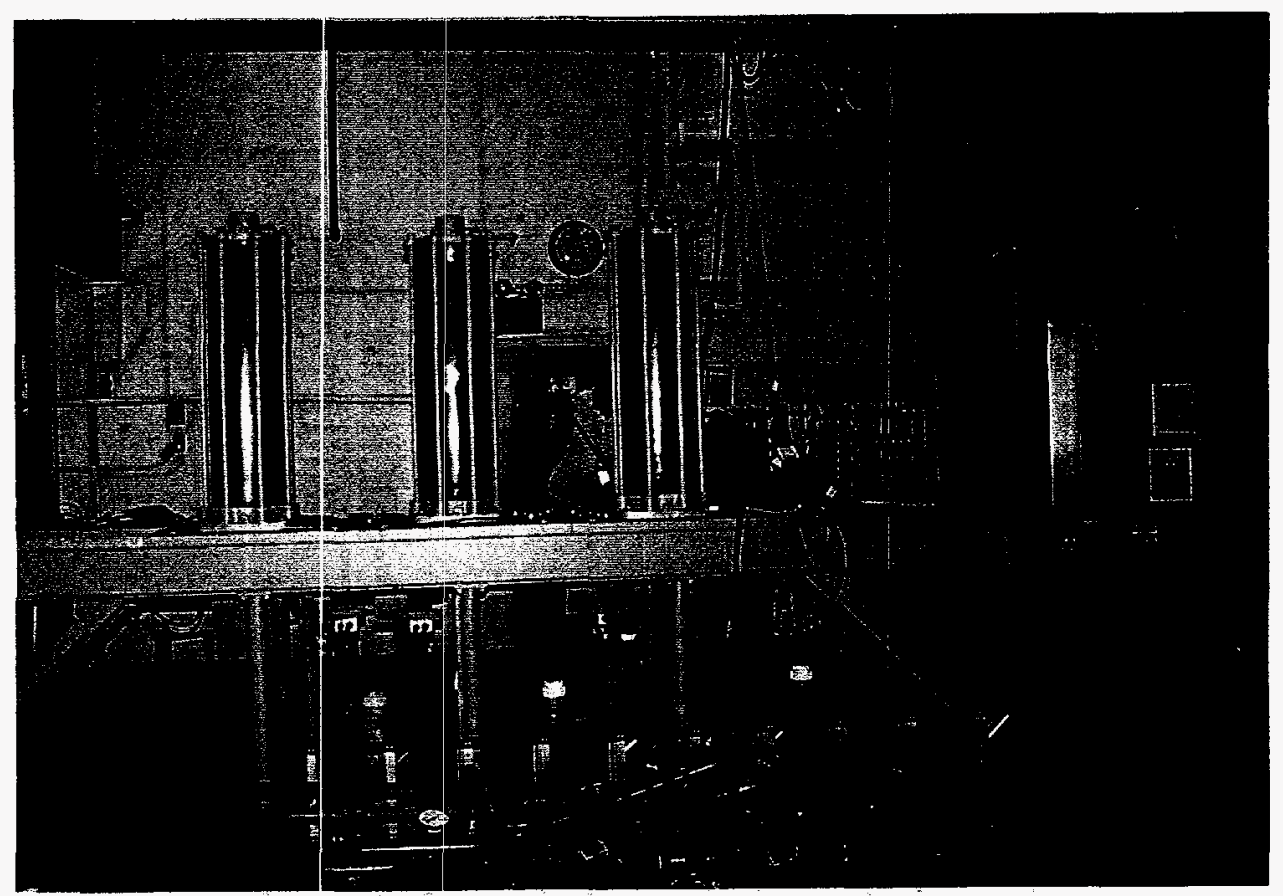

Figure 6.42 Technicians Removing Air System Piping and Shutter Drive Actuator (ANL Negative \#22683K, Frame \#10)

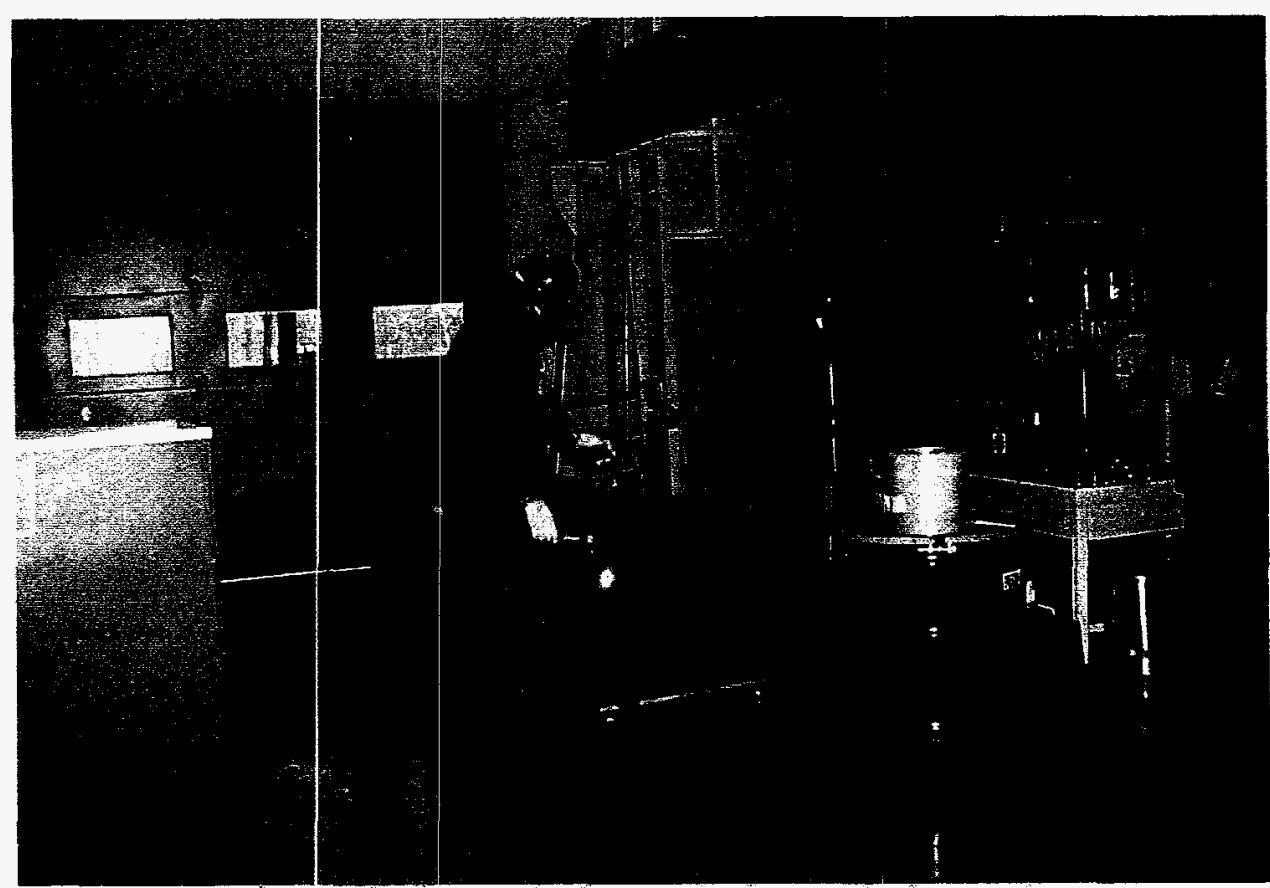

Figure 6.43 Health Physics Technician Surveying Shutter Drive Air Cylinder for "Free Release" (ANL Negative \#22683K, Frame \#16) 


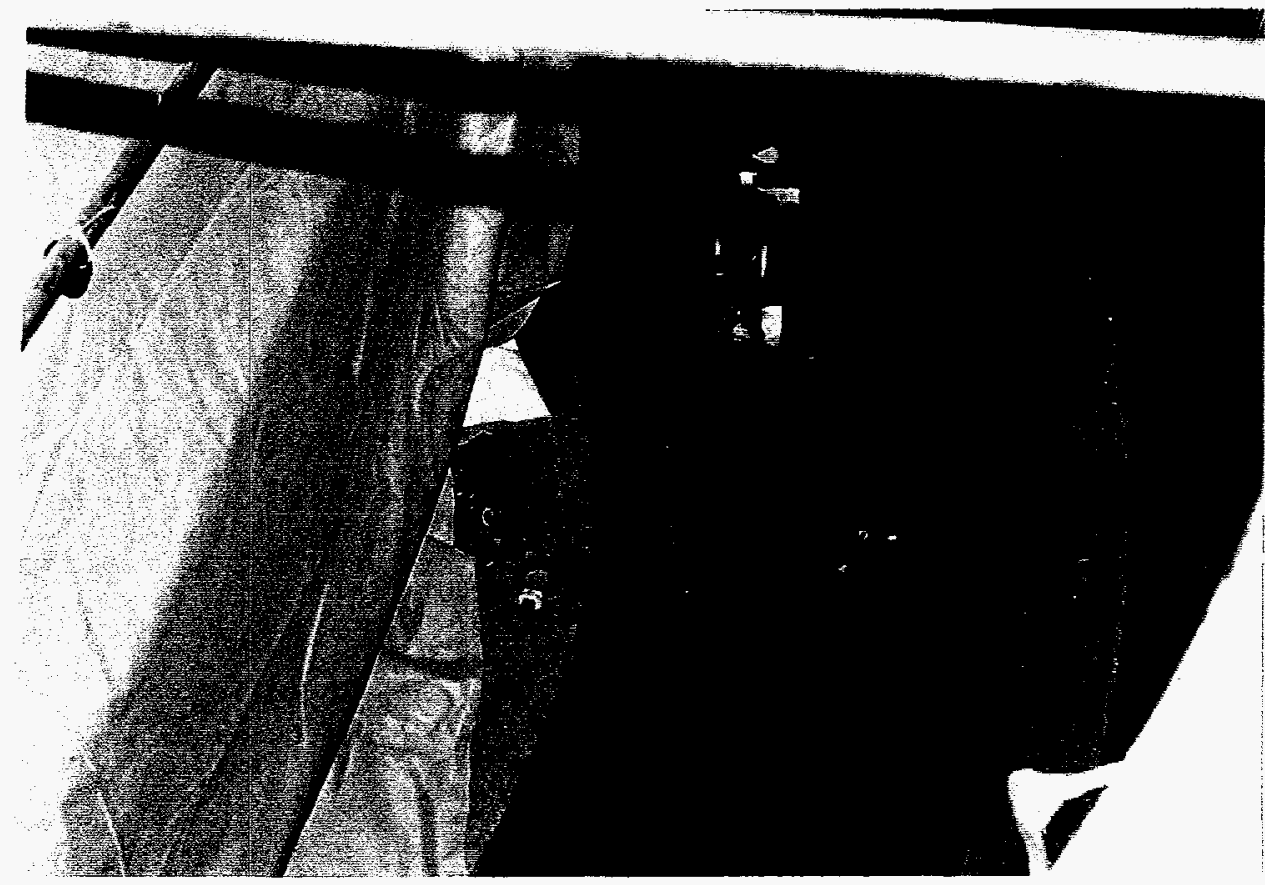

Figure 6.44 High-Dose Shutter Being Removed (ANL Negative \#23322K, Frame \#5)

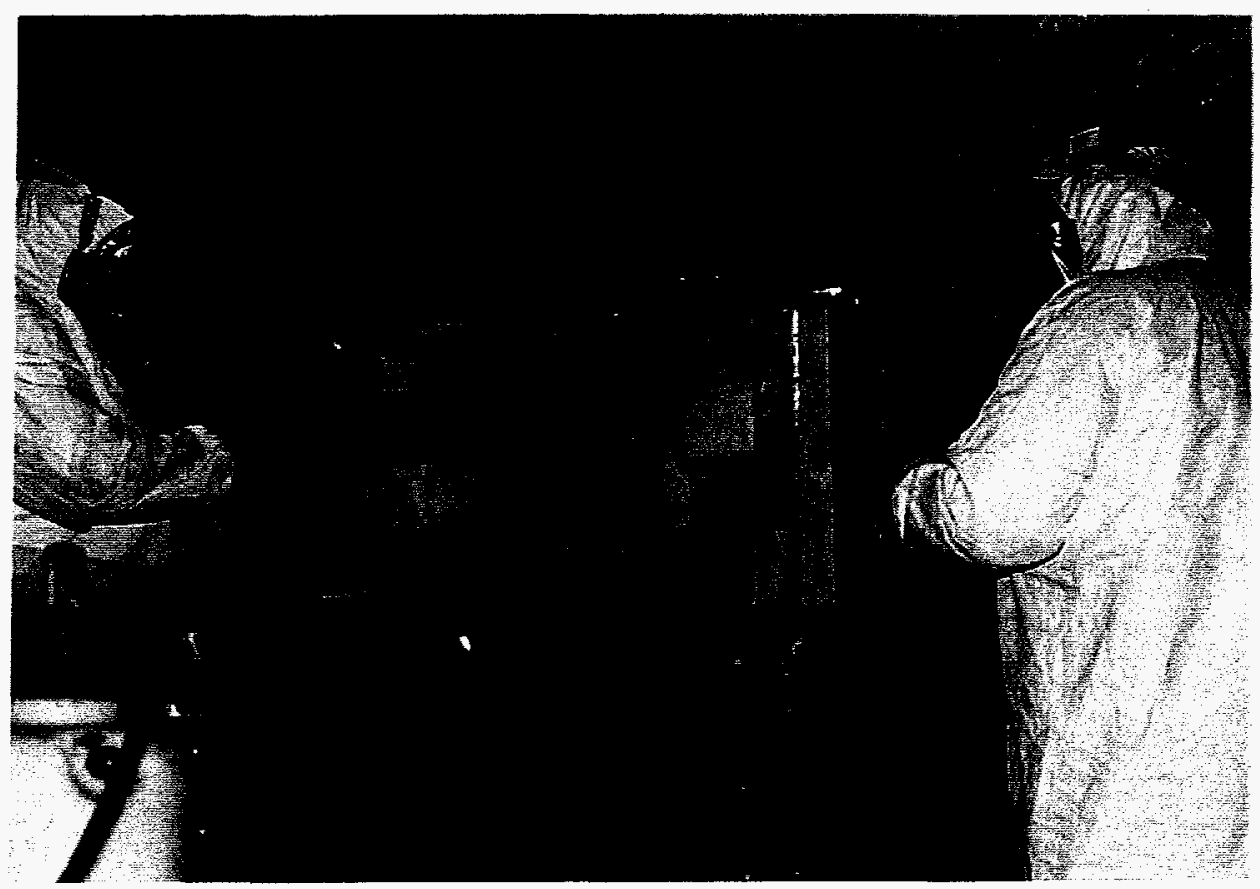

Figure 6.45 Technicians Removing Lead and Polyethylene Blocks from Inside of a High-Dose Shutter (ANL Negative \#23322K, Frame \#20) 


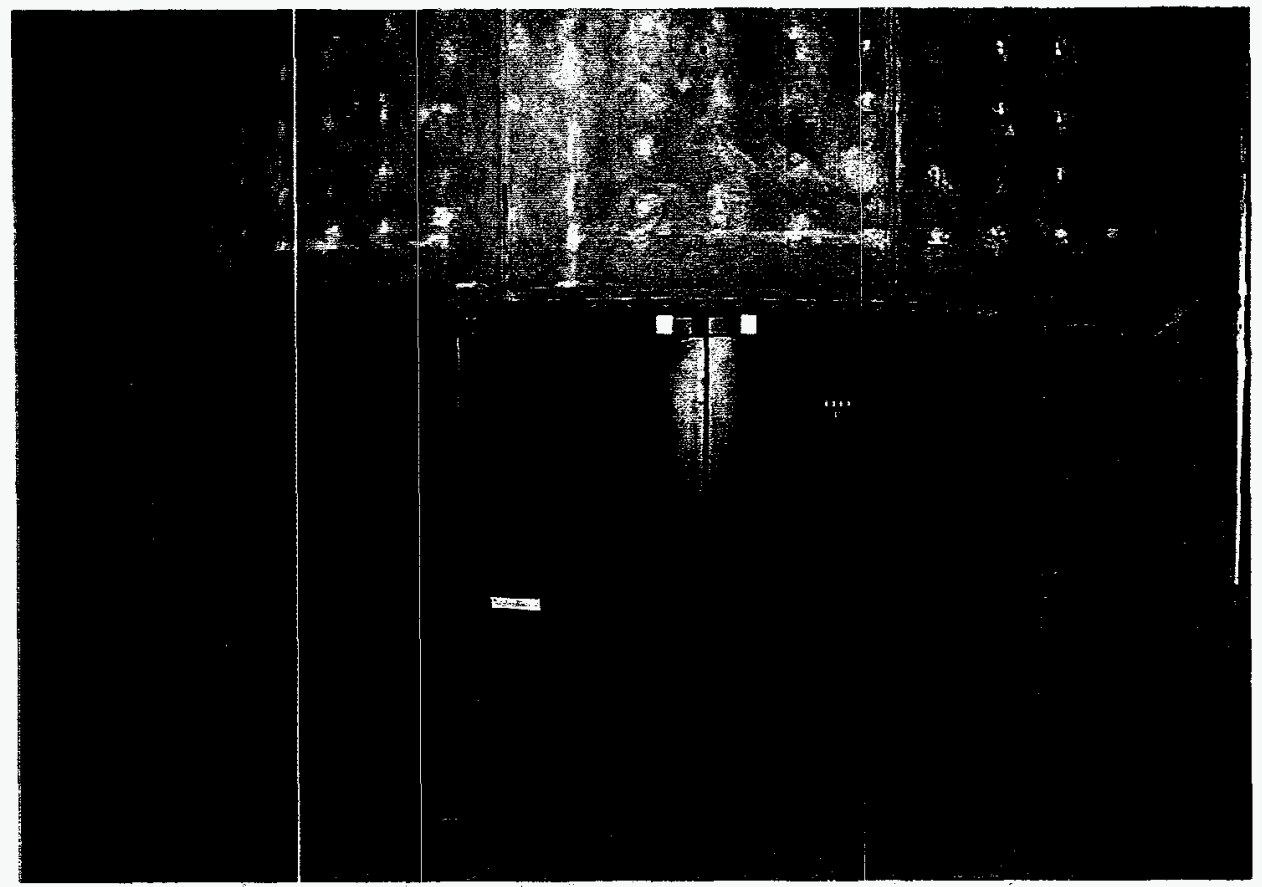

Figure 6.46 Low-Dose Shutters and Pedestals Prior to Removal (ANL Negative \#22891K, Frame \#16)

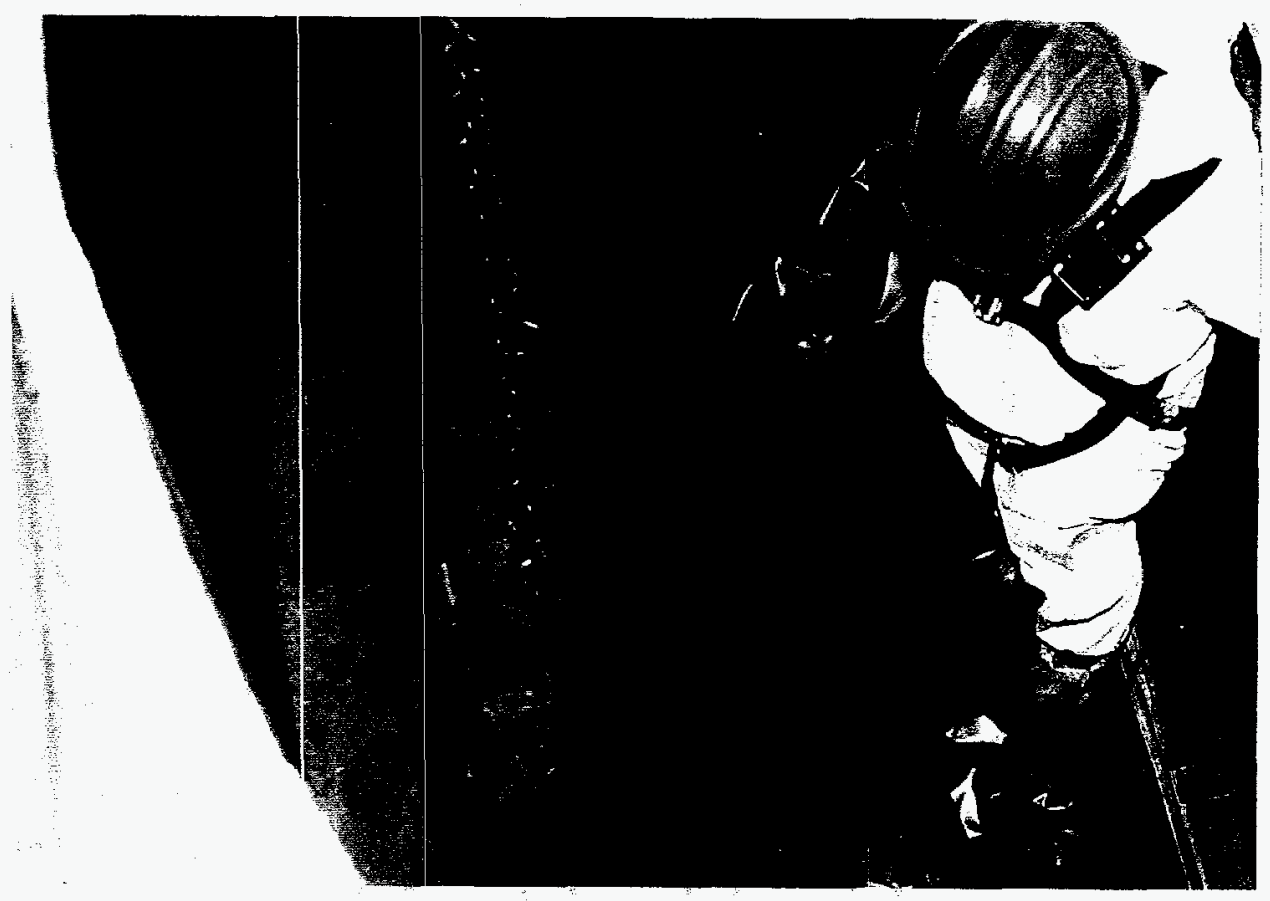

Figure 6.47 Low-Dose Shutter Being Removed (ANL Negative \#23216K, Frame \#15A) 


\subsubsection{Activated Structure Removal}

Activated materials present near the reactor consisted of activated bioshield concrete, the converter plate frame, the gamma attenuator pedestal and the reactor pedestal. The following sections describe the removal of these items.

\subsubsection{Activated Bioshield Removal}

The activated bioshield consisted of the concrete "bridges" located on top of the steel shell above the high- and low-dose windows, the concrete "wings" located directly north and south of the steel shell and the reactor pedestal which supported the steel shell. These concrete structures were removed utilizing electric and pneumatic jackhammers, Bristar ${ }^{\mathrm{TM}}$ expanding grout and the BROKK 150 semi-remote, portable hydraulic jackhammer. Concrete removal was performed inside a HEPA-ventilated containment enclosure to control the spread of activated concrete dust. The concrete was packaged into $55 \mathrm{gal}$ (208.18 1) drums and steel waste bins for disposal as low-level radioactive waste. This work was started on May 14, 1997 and completed on September 10, 1997. Figures 6.48 and 6.49 show activated bioshield removal.

\subsubsection{Converter Frame Removal}

The converter frame supported the converter plate on the high-dose side of the reactor. The converter plate contained highly enriched uranium used in the production of fast neutrons for experimental purposes. It had been removed prior to the start of D\&D operations. The converter frame was manually removed, size reduced and packaged as low-level radioactive waste. This activity was performed on September 10, 1997.

\subsubsection{Gamma Attenuator Pedestal Removal}

The gamma attenuator pedestal was constructed of lead block and was manually disassembled, surveyed and released to the ANL-E lead bank for reuse. This work was performed on March 19, 1997.

\subsubsection{Control Room Facilities Removal}

Removal of the control facilities required dismantlement of the reactor control panels, low-dose control panels and the high-dose control panels. The following sections describe the removal of these items. 


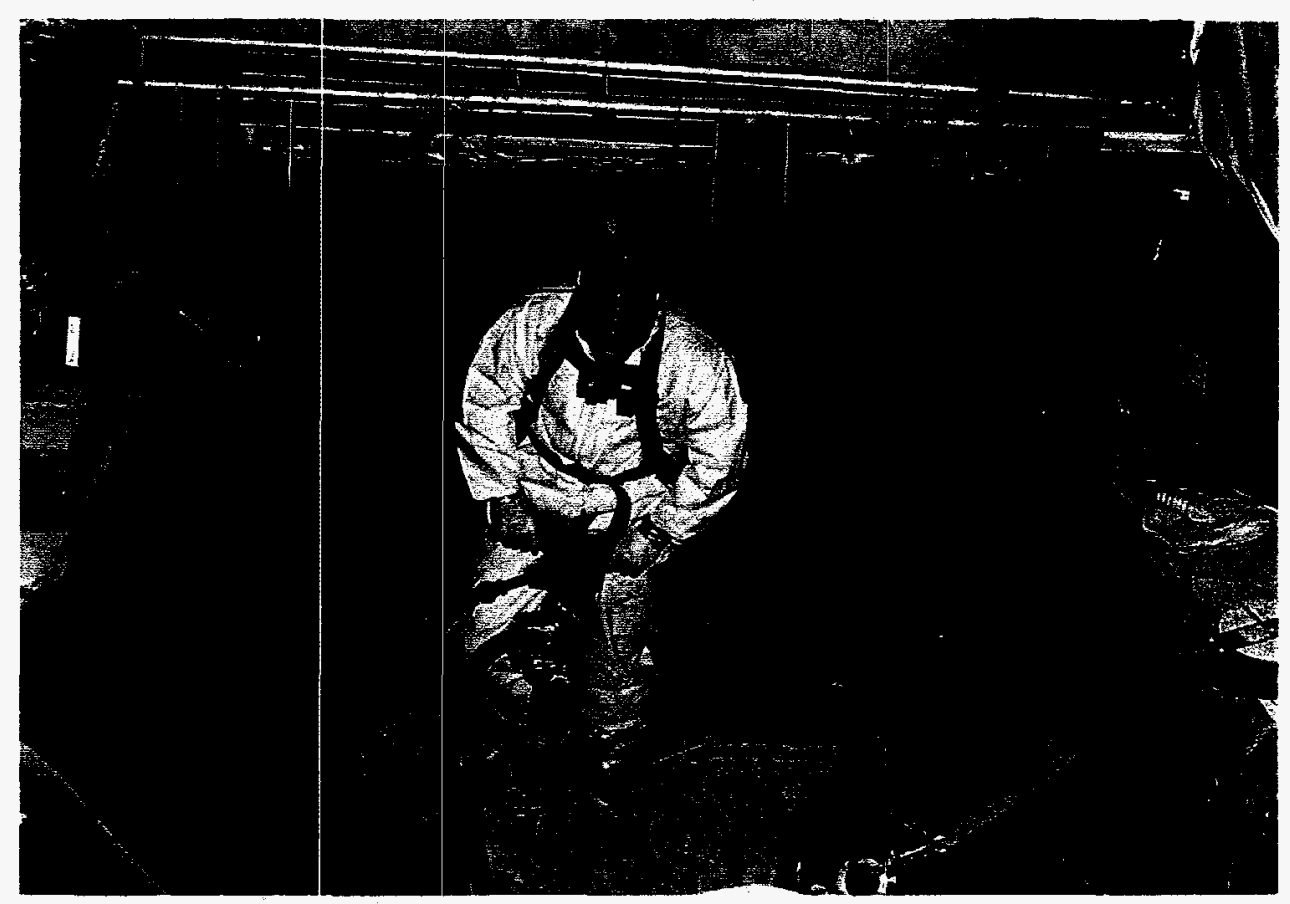

Figure 6.48 Technician Removing Concrete from South "Wing" Wall with a $90 \mathrm{lb}(40.82 \mathrm{~kg})$ Jackhammer

(ANL Negative \#23416K, Frame \#10A)

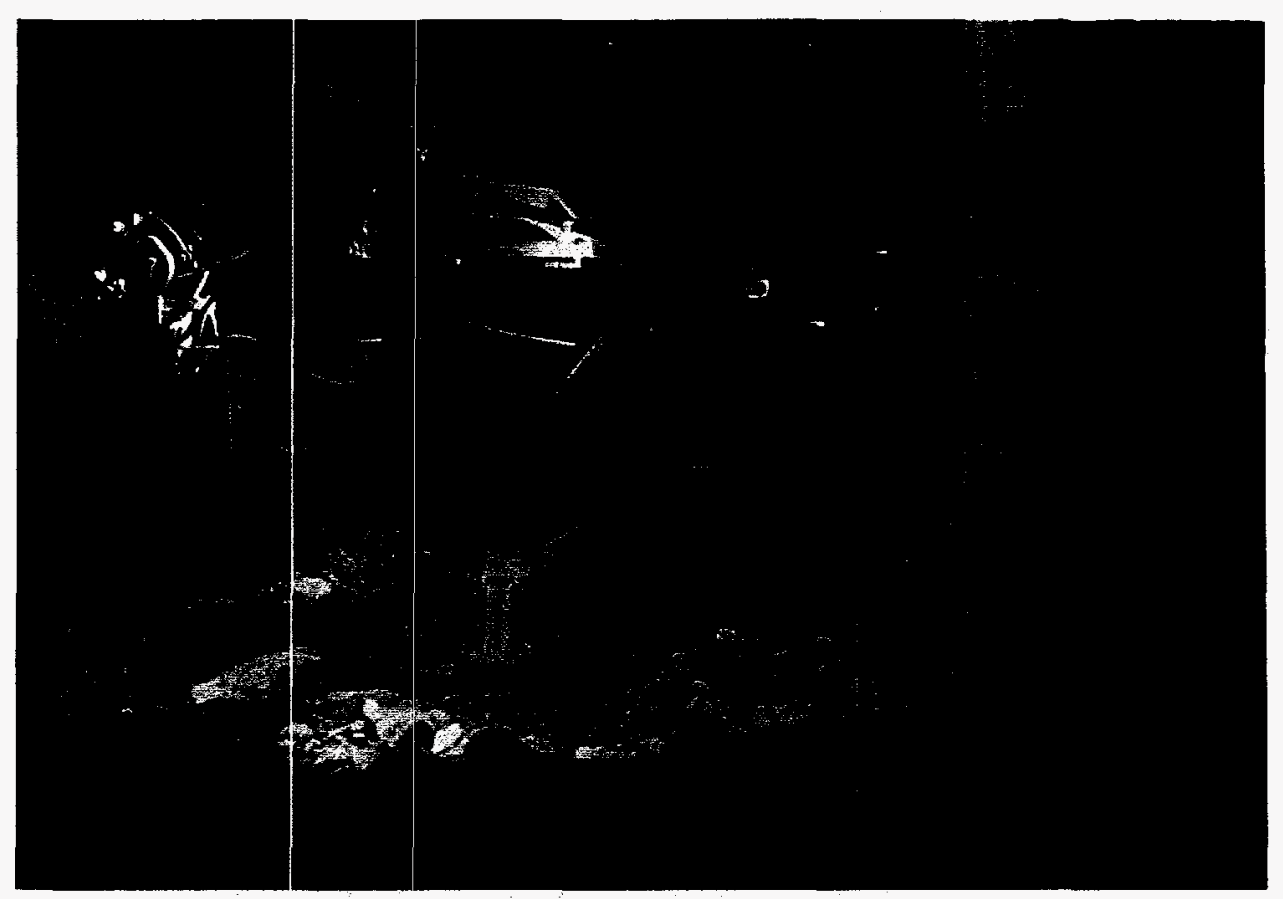

Figure 6.49 BROKK 150 Removing Reactor Pedestal Concrete (ANL Negative \#23458K, Frame \#25) 


\subsubsection{Low-Dose Room Control Panel Removal}

The low-dose room control panels were located in the low-dose preparation room on the service floor of the JANUS Reactor facility and housed various controls and power supplies for performing experimental work. Prior to removal, power to the control console was LO/TO. After electrical isolation, the panels were manually disassembled, surveyed for free release and disposed of as clean scrap. This work was started on February 4, 1997 and completed on February 28, 1997. Figures 6.50 and 6.51 show the dismantlement of the low-dose control panels.

\subsubsection{High-Dose Room Control Panel Removal}

The high-dose room control panel was located in the high-dose preparation room and housed controls and power supplies for performing experimental work. Power was disconnected and LO/TO, and the panel was dismantled, surveyed and free released as clean scrap. This work was started on February 4, 1997 and completed on February 28, 1997.

\subsubsection{Reactor Control Console Removal}

The reactor control consoles were located in the reactor control room on the main floor; they provided control power for reactor operation as well as instrumentation readouts for monitoring reactor operation. Power was isolated to the control panels and LO/TO, and dismantling began. On January 30,1997, two energized emergency power circuits were cut during dismantlement work. These circuits were added after completion of the reactor facility and did not appear on any available drawings. All work was stopped and an investigation was ordered by the ANL Project manager. A detailed account of this event is provided in Section 12.0 of this report. As a result of the investigation, the dismantlement procedure was revised and additional electrical monitoring equipment was purchased prior to restarting dismantlement operations. The consoles were dismantled, surveyed for free release and disposed of as clean scrap. This work was started on January 29, 1997 and completed on January 31, 1997. Figures 6.52 and 6.53 show control room console dismantlement operations.

\subsubsection{Experimental Equipment Removal}

Several pieces of experimental equipment and associated controls were dismantled, surveyed and released as clean scrap. This work was performed from February 24, 1997 to March 4, 1997.

\subsubsection{Systems Removal}

Systems removal consisted of dismantlement of the secondary cooling system, primary water system, reactor and graphite helium system and the level control and skimmer system. These systems were primarily located in the reactor equipment room on the service floor of the JANUS Reactor facility. The following sections describe the removal of these systems. Figures 6.54 and 6.55 show removal of these systems. 


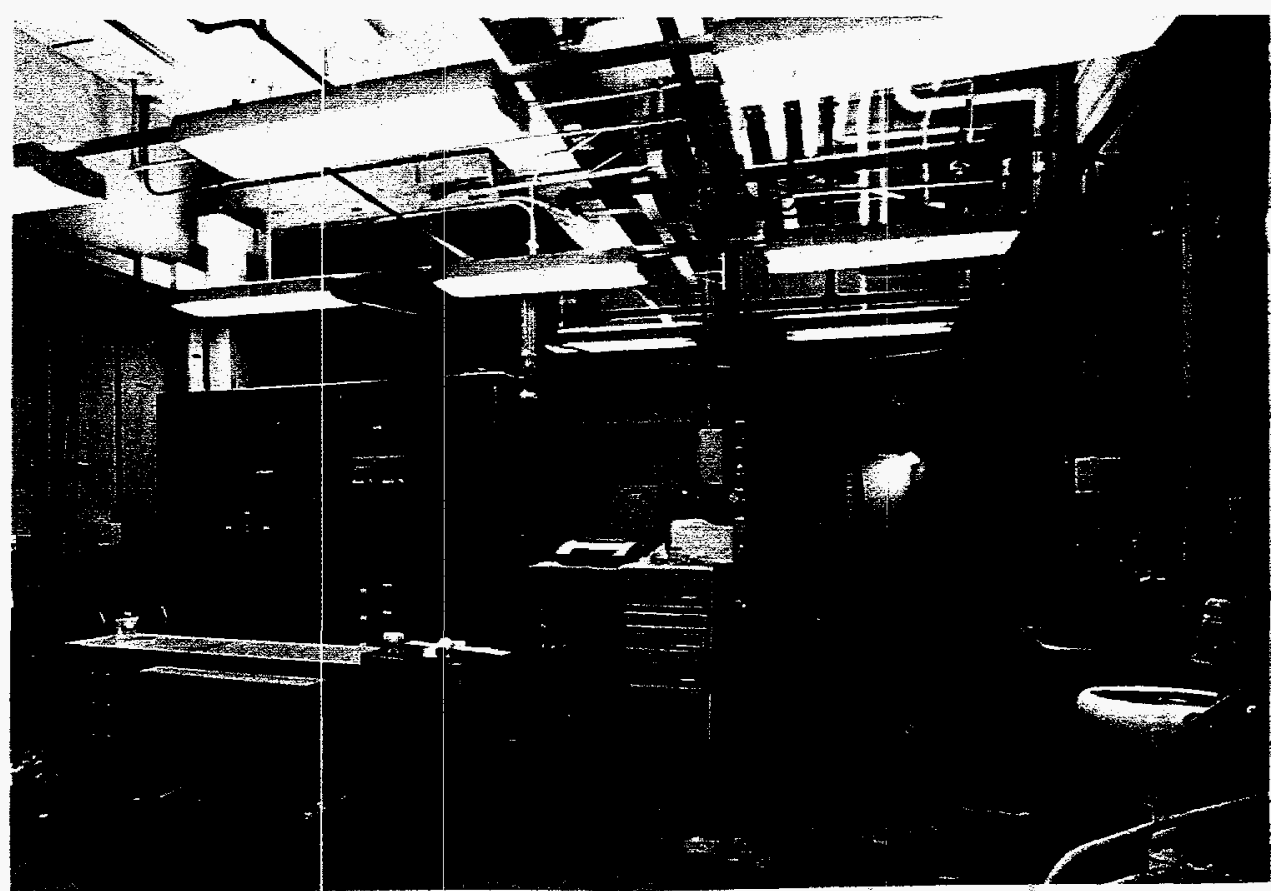

Figure 6.50 Low-Dose Control Panel Prior to Disassembly (ANL Negative \#22163K, Frame \#7A)

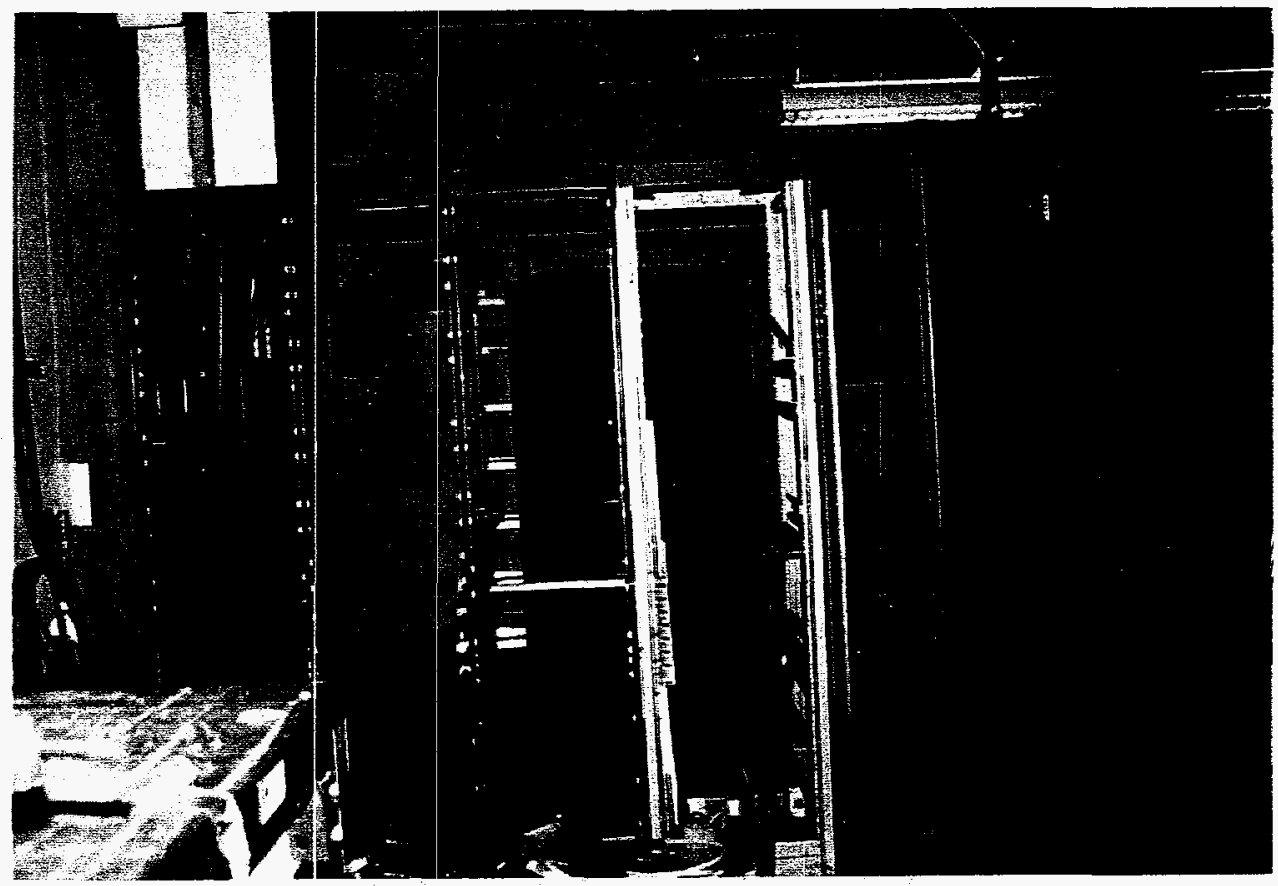

Figure 6.51 Low-Dose Control Panel Partially Disassembled (ANL Negative \#22760K, Frame \#4A) 


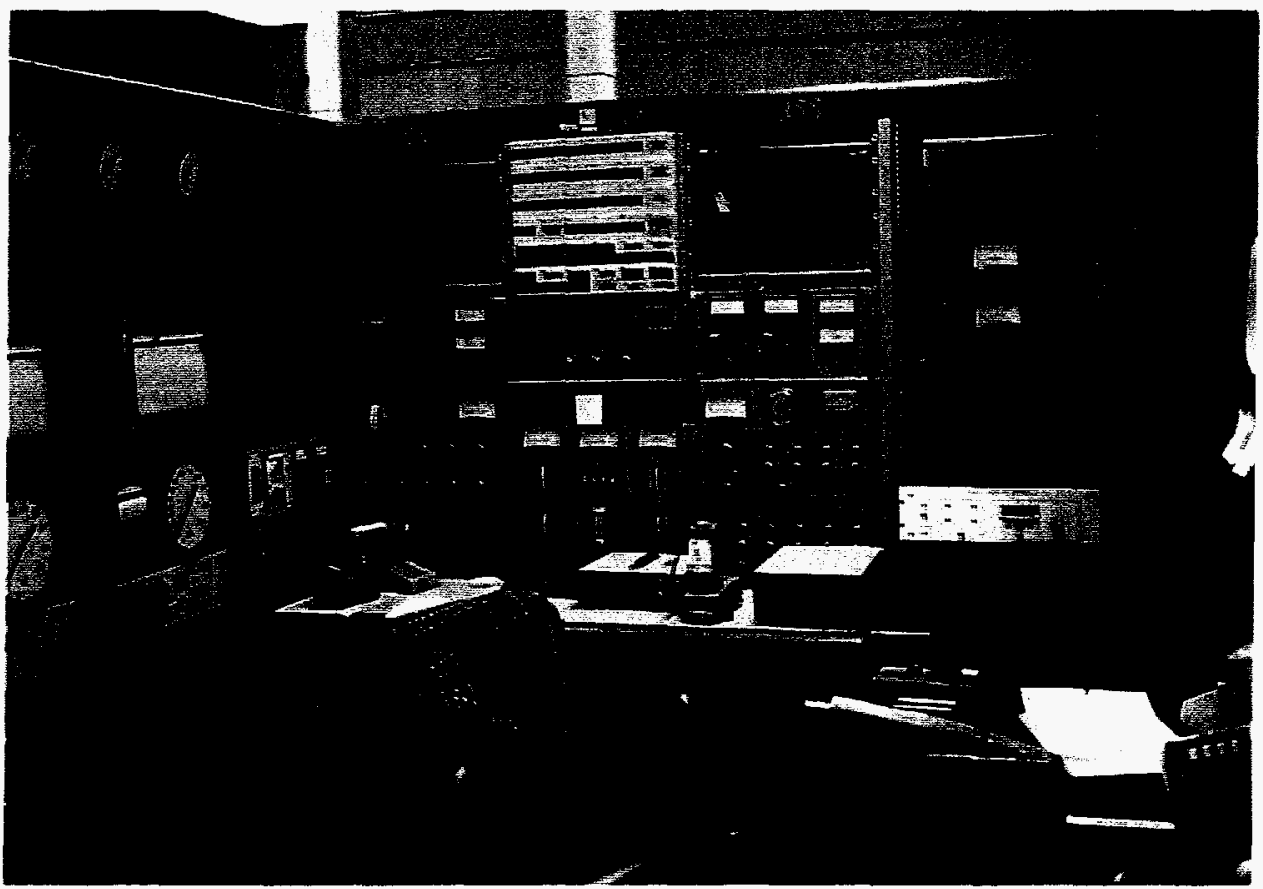

Figure 6.52 Reactor Control Panel Prior to the Start of Disassembly (ANL Negative \#22683K, Frame \#5)

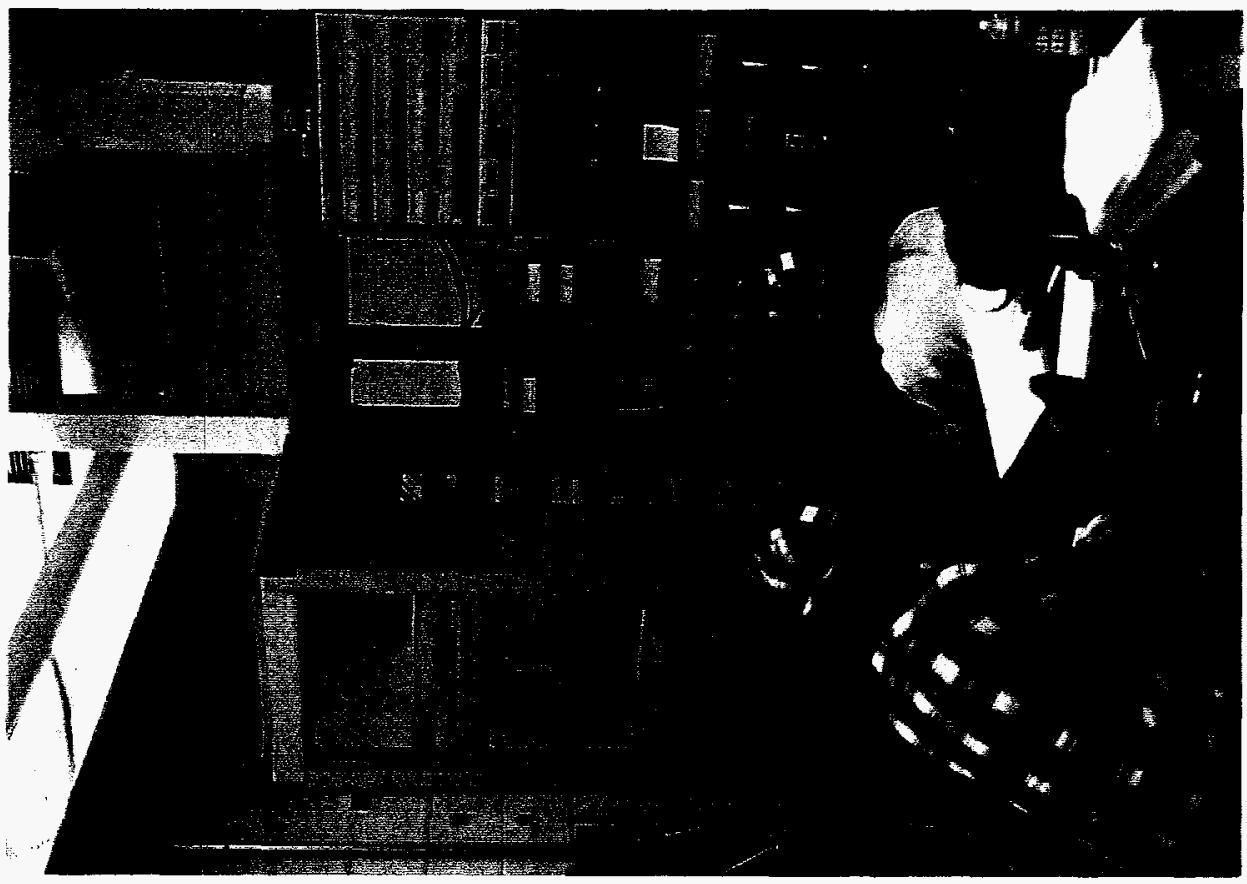

Figure 6.53 Technician Disassembling the Reactor Control Panel (ANL Negative \#22719K, Frame \#4) 


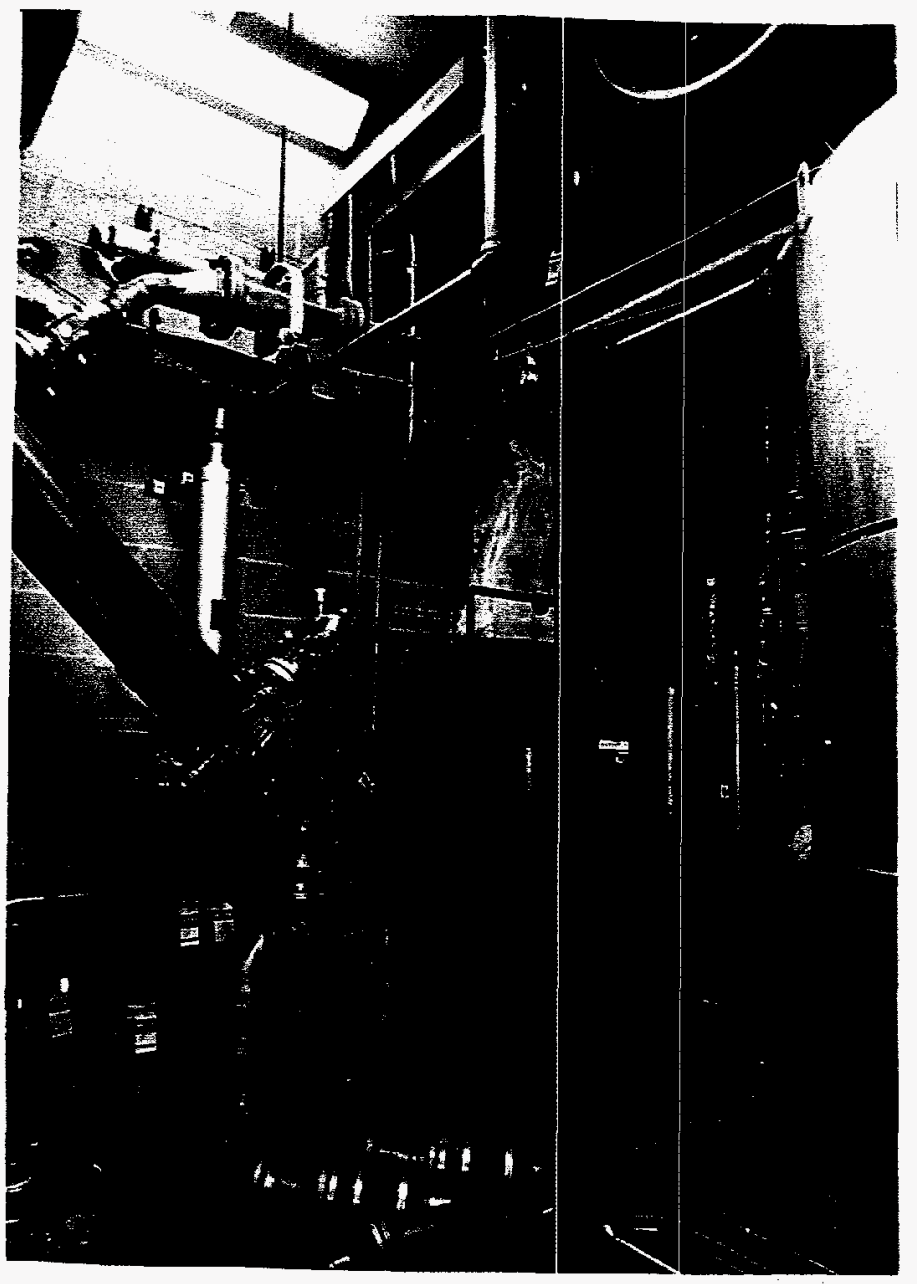

Figure 6.55 Technician Disassembling Systems in the Reactor Equipment Room (ANL Negative \#22846K, Frame \#19A)

Figure 6.54 Reactor Equipment Room Prior to the Dismantlement of Primary and Secondary Systems (ANL Negative \#22164K, Frame \#IOA)

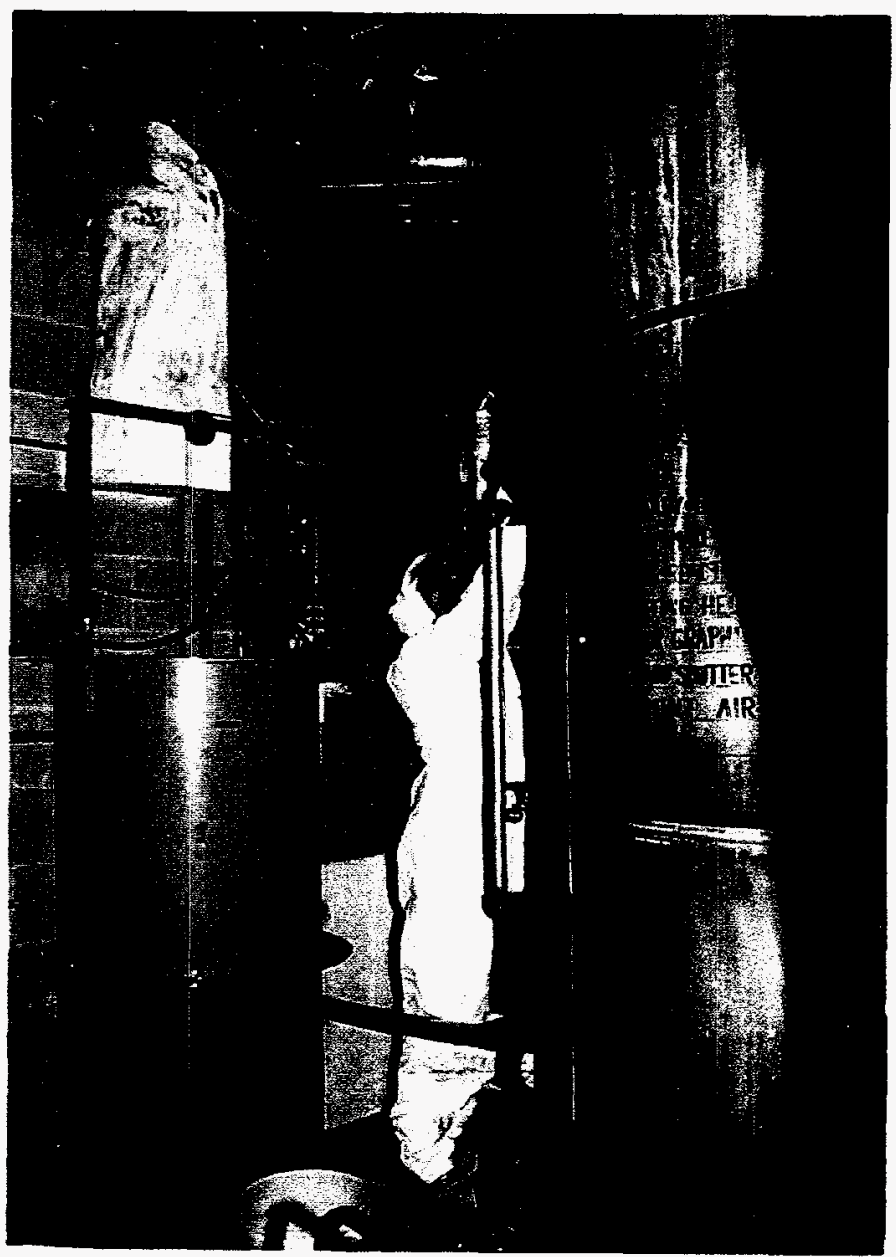




\subsubsection{Secondary Cooling System Removal}

The secondary cooling system removed heat which was transferred to the primary coolant loop from the reactor fuel elements. The system comprised piping, pumps, two heat exchangers and a cooling tower. Primary water was circulated through the two heat exchangers where reactor heat was transferred to the secondary coolant. The secondary water was circulated through the cooling tower where the heat was dissipated to the atmosphere. Removal of the secondary cooling system consisted of mechanical disassembly of the pumps, piping, valves and heat exchangers. After removal, the piping was size reduced with portable electric saws and surveyed for free release as clean scrap and/or packaged as low-level radioactive waste. This work began on March 4, 1997 and was completed on May 7, 1997.

\subsubsection{Primary Water System Removal}

The primary water system consisted of two coolant pumps, piping, a storage tank and associated valves that circulated primary coolant through the core, removing heat produced by the reactor and transferring it to the secondary cooling system via the two heat exchangers. Removal of the primary system consisted of mechanical disassembly of the pumps, piping and valves. After disassembly, the system piping and storage tank were size reduced with portable electric saws and packaged for disposal as low-level radioactive waste. This work was started on March 5, 1997 and completed on April 3, 1997.

\subsubsection{Helium System Removal}

The reactor helium system and graphite helium system supplied a controlled atmosphere of inert gas to the reactor tank and graphite reflector. Both systems shared a helium supply from gas cylinders and regulating valves which fed helium to their respective zones. Off-gas was directed to the exhaust stack for dispersal to the atmosphere. The system was mechanically disassembled, size reduced and packaged as low-level radioactive waste or surveyed for free release as clean scrap. This work was performed from March 11, 1997 to April 3, 1997.

\subsubsection{Level Control and Skimmer System Removal}

The level control and skimmer system was utilized to maintain a constant reactor tank level by skimming the surface film or scum from the top of the reactor tank and filtering the aluminum oxide particles which formed on the surface of the reactor coolant inside the reactor tank. The system was mechanically disassembled, size reduced and packaged as low-level radioactive waste. This work began on March 11, 1997 and was completed on April 3, 1997. 


\subsubsection{Storage Facilities and Excess Material}

\subsubsection{Spent Fuel Transjer Cask Removal}

The spent fuel transfer cask was constructed of lead and depleted uranium encased in a steel shell. It had been used for transferring spent reactor fuel from the JANUS Reactor facility to the CP-5 Reactor spent fuel pool. The steel shell was segmented from the cask at the lead and depleted uranium interface and separated from the depleted uranium. This allowed the depleted uranium to be packaged as low-level radioactive waste. The lead was recovered and transferred to the ANL-E lead bank for reuse. This work began on July 18, 1997 and ended on July 23, 1997.

\subsubsection{Excess Lead Removal}

A large amount of excess lead brick had been stored in the JANUS Reactor facility. The lead was surveyed for free release, stacked on pallets, wrapped in plastic and transferred to the ANL-E lead bank for reuse. This task was completed on March 5, 1997.

\subsubsection{Seal Pipe Tunnel}

A pipe tunnel between the reactor equipment room and the top of the reactor provided space for pipes and electrical cable. After removing the piping and cable, the tunnel was sealed with a cover. This task was completed on May 30, 1997.

\subsubsection{Decontaminating and Sealing the Fuel Storage Tubes}

Two $10 \mathrm{ft}(304.8 \mathrm{~cm})$ deep fuel storage tubes were located on the north side of the high bay floor. These tubes were capable of storing fuel, if required. No evidence could be found that fuel had ever been stored in the tubes. The tubes were HEPA vacuumed, surveyed clean and sealed. This work was performed on April 16, 997.

\subsection{Close-Out Operations}

\subsubsection{Decontaminate and Wipe Down Surfaces}

At the completion of all D\&D activities and prior to starting the final status survey, the facility was wiped down with damp rags. This work was performed from June 9, 1997 to September 19, 1997.

\subsubsection{Perform Final Survey}

A final status radiological survey was performed on the JANUS Reactor Facility at the completion of the D\&D phase of work. The survey was performed in accordance with NUREG/CR-5849 Manual for Conducting Radiological Surveys in Support of License Termination and the approved 
final survey plan. Details of the final status survey are provided in Section 7.0. The final status survey started on May 8, 1997 and was completed on October 3, 1997.

\subsubsection{Obtain and Analyze Samples}

In conjunction with the final status survey, paint and concrete samples were collected and analyzed for residual activity. Details of the types of sampling performed are provided in Section 7.0. Sample collection and analyses were performed between August 28, 1997 and September 5, 1997.

\subsubsection{Demobilize Site}

Upon completion of the final survey the contractor demobilized from the site. Demobilization consisted of archiving all records and data, packaging and shipping equipment and supplies and disbanding the project staff. Demobilization was completed on September 30, 1997.

\subsubsection{Prepare Final Report}

The final project activity consisted of preparation of this final report. This report incorporates information and data from several documents i.e., the JANUS Characterization Report (March 1996) and the Final Project Report and Final Survey Report prepared by Afftrex, Ltd. The final report was submitted on October 28, 1997.

\subsection{POST-DECOMMISSIONING RADIOLOGICAL SURVEY}

\subsection{Final Survey Objectives}

The purpose of the final status survey was to demonstrate that the radiological conditions at the JANUS Reactor facility satisfied the unrestricted release guidelines presented found in the following documents:

- $\quad$ ANL-E Environment, Safety and Health Manual

- Radiological Controls Plan (Afftrex document JANUS-SP-03)

- Termination of Operating Licenses for Nuclear Reactors (Nuclear Regulatory Commission Regulatory Guide 1.86)

- Radiation Protection of the Public and the Environment (DOE Order 5400.5)

- Surface Contamination Surveys for Unrestricted Release of Equipment and Materials (ANL-E Health Physics Procedure HPP-610) 


\subsubsection{Release Survey Conditions}

The following specific conditions were established for the release survey:

- $\quad$ Average surface contamination levels for each survey unit were within the authorized guideline values.

- Small areas of residual activity (hot spots) were limited to no greater than $100 \mathrm{~cm}^{2}$, and the presence of an elevated area did not result in the average for the entire $1 \mathrm{~m}^{2}$ survey area exceeding allowable guideline values.

- A reasonable effort was demonstrated to clean up removable activity; any remaining removable activity did not exceed the guideline value.

- Exposure rates in accessible and normally occupied locations were in accordance with the guideline values.

\subsubsection{Unrestricted Release Criteria}

Based on the contaminants present at the JANUS Reactor facility, the release criteria specified for the project were as follows:

\section{Beta-Gamma Contamination}

- $5,000 \mathrm{dpm}(83 \mathrm{~Bq}) / 100 \mathrm{~cm}^{2}$, beta-gamma fixed and removable (total) contamination, averaged over $1 \mathrm{~m}^{2}$;

- $\quad 15,000 \mathrm{dpm}(250 \mathrm{~Bq}) / 100 \mathrm{~cm}^{2}$, maximum beta-gamma fixed and removable (total) contamination over $100 \mathrm{~cm}^{2}$; and

- $1,000 \mathrm{dpm}(17 \mathrm{~Bq}) / 100 \mathrm{~cm}^{2}$, removable beta-gamma contamination.

\section{Alpha Contamination}

- $100 \mathrm{dpm}(1.67 \mathrm{~Bq}) / 100 \mathrm{~cm}^{2}$, alpha fixed and removable (total) contamination, averaged over $1 \mathrm{~m}^{2}$;

- $\quad 300 \mathrm{dpm}(5 \mathrm{~Bq}) / 100 \mathrm{~cm}^{2}$, maximum alpha fixed and removable (total) contamination over $100 \mathrm{~cm}^{2}$, and

- $20 \mathrm{dpm}(0.3 \mathrm{~Bq}) / 100 \mathrm{~cm}^{2}$, removable alpha contamination.

\section{Exposure Rates}

- Exposure rates in occupiable locations are less than $15 \mu \mathrm{R} / \mathrm{hr}\left(15 \times 10^{-3} \mathrm{mSv} / \mathrm{hr}\right)$ including background as measured 1 meter from floor/lower wall surfaces and averaged over floor areas of $<4 \mathrm{~m}^{2}$. Where exposure rates in excess of $15 \mu \mathrm{R} / \mathrm{hr}\left(15 \times 10^{-3} \mathrm{mSv} / \mathrm{hr}\right)$ 
are caused by close wall geometries (where natural background exposure rates may appear elevated due to the greater photon fluence close to a wall as opposed to in free space at a distance from the wall) or residual activation products remain, a projected dose assessment was performed. The area was considered acceptable if the resulting annual dose did not exceed $15 \mathrm{mrem}(150 \mu \mathrm{Sv})$.

For purposes of final survey release status, all "unrestricted release" guideline values are referred to as Release Concentration Guideline Levels (RCGL's)

\subsubsection{Volume Activity of Building Materials}

Reasonable effort was made to identify and remove all activated structural material. Where activation still exists, the residual exposure rates result in doses less than $15 \mathrm{mrem} / \mathrm{yr}(150 \mu \mathrm{Sv} / \mathrm{yr})$ for a 2000-hour occupancy.

\subsubsection{Coated Surfaces}

Reasonable efforts were made to identify and remove contaminated paint or coatings on the JANUS Reactor facility interior surfaces.

\subsection{Final Survey Approach}

\subsubsection{Definitions}

The following definitions were applied in the final survey:

- Affected Area - any area that meets one of the following conditions:

- Areas that have the potential for radioactive contamination due to process operations or as a result of spills or leaks of contaminated systems.

- Any area originally classified as unaffected which subsequently is found to have contamination levels in excess of $25 \%$ of the RCGLs.

- Biased Survey - a survey performed at locations likely to contain residual contamination.

- Characterization Survey - a survey with limited numbers and types of measurements obtained from site locations considered to be the most likely to contain residual activity, and from other locations expected to have been affected by site operations.

- Final Status Survey - the final status survey of the area demonstrating that it meets the established acceptance criteria. 
- Grid - a system of intersecting lines referenced to a fixed site location or bench mark. The grid lines are arranged in a perpendicular pattern, dividing the survey area into squares of equal area.

- Lower Wall - the portion of the wall that extends from the floor to a height of $2 \mathrm{~m}$ above the floor.

- $\quad$ Release Concentration Guideline Levels (RCGLs) - radionuclide-specific concentration in media or surface contarnination levels that, when exceeded, may result in an individual who is occupying the affected area to exceed a regulatory dose limit or guide. As used in the JANUS Reactor facility final status survey, RCGLs are considered to be the stated unrestricted release criteria in the ANL-E Environment, Safety and Health Manual and DOE Order 5400.5, Radiation Protection of the Public and the Environment. A lowerbound RCGL may be used to decide how many samples are required to justify rejection of a null hypothesis of "contamination above the RCGL is present." For very small areas with elevated levels of contamination above the RCGL, a higher-bound RCGL $\left(\mathrm{RCGL}_{\text {elevated }}\right)$ may be used provided the resulting potential dose or risk is reasonably equivalent to one from a larger area uniformly contaminated to levels below the normal RCGL.

- Static Survey - a survey using the meter in a scaler integrated mode in a stationary position over the surface being surveyed.

- Survey Unit - a division of a survey area that is expected to have similar contamination and deposition patterns (e.g., floors, lower walls, horizontal surfaces). The maximum survey unit size is approximately $100 \mathrm{~m}^{2}$ for affected areas; no survey unit will include both affected and unaffected areas.

- Survey Location - the survey data point within a grid square or in an ungridded area.

- Survey Package - the portfolio for a specific area being surveyed. Each survey package contains the details for surveillance, including sample locations, types of measurements, sample point selection criteria, background determinations, maps, diagrams and the results and analyses of all data collected.

- Unaffected Area - all areas not classified as affected. These areas are not expected to contain residual radioactivity because either operations did not generate radioactive contaminants in those areas or movement of radioactive material into those areas was controlled to eliminate the potential for spills or leaks or was not done at all. 


\subsubsection{Potential Contaminants}

Table 5.1 lists the nuclides identified during the characterization and performance of D\&D operations. Based on knowledge of site operations, the results of the characterization survey performed in 1996 and the information obtained during the actual D\&D of the JANUS Reactor facility, the primary radionuclides of concern were considered to be $\mathrm{Co}^{60}, \mathrm{Eu}^{152}, \mathrm{Eu}^{154}$, and $\mathrm{Pu}^{239}$ (to a lesser extent). The levels of contamination found during the characterization survey and during $D \& D$ operations at the facility were generally less than unrestricted release guideline levels except for those surfaces in direct contact with primary coolant or irradiated materials adjacent to the core area (within a $5 \mathrm{ft}(152.5 \mathrm{~cm})$ diameter).

\subsubsection{General Survey Plan}

\subsubsection{Survey Area Classifications}

Areas were classified as either unaffected or affected (see Table 7.1), as defined below.

- Unaffected Areas - All following areas within the JANUS Reactor facility were considered unaffected areas: the men's (J-116) and women's (J-114) restrooms, the fan room $(\mathrm{J}-102)$, the corridor adjacent to the facility entrance and stairway \#7. Historical data regarding the operation of the reactor and measurements made during the characterization of the facility indicated that no use or spread of contamination into these areas was likely. A series of spot-check measurements found no contaminants above $25 \%$ of the RCGL's in affected areas.

- Affected Areas - Affected areas were divided into groups having either a low or high probability of containing contaminants. Areas such as the control room (J-112), final filter room (J-101), glovebox room (J-120), mechanical room (J-118), low-dose prep room (J-014), high-dose prep room (J-002) and low-dose room (J-015) could possibly have been affected, but data on the operations performed in these areas and results of previous surveys indicated that these rooms were unlikely to contain contaminants. These areas were surveyed to statistically verify that residual contamination was less than the RCGL's.

The reactor area (J-200), high-bay area (J-105), high-dose room (J-007) and reactor equipment room (J-010) were four areas where activation or contamination in excess of the RCGL's was known to be present. These areas were extensively surveyed to verify that residual activity had been reduced to below the RCGL's. 
Table 7.1 Survey Area Identification and Classification

\begin{tabular}{|l|l||}
\hline \multicolumn{1}{|c|}{ Area Identification (Room) } & \multicolumn{1}{|c|}{ Area Classification } \\
\hline \hline Reactor Area (J-200) & Affected (High Probability) \\
\hline High Bay (J-105) & Affected (High Probability) \\
\hline High-Dose Room (J-007) & Affected (High Probability) \\
\hline Reactor Equipment Room (J-010) & Affected (High Probability) \\
\hline Low-Dose Room (J-015) & Affected (Low Probability) \\
\hline Glovebox Room (J-120) & Affected (Low Probability) \\
\hline Final Filter Room (J-101) & Affected (Low Probability) \\
\hline High-Dose Prep. Room (J-002) & Affected (Low Probability) \\
\hline Low-Dose Prep. Room (J-014) & Affected (Low Probability) \\
\hline Control Room (J-112) & Affected (Low Probability) \\
\hline Mechanical Room (J-118) & Affected (Low Probability) \\
\hline Fan Room (J-102) & Unaffected \\
\hline Corridor (J-108) & Unaffected \\
\hline Women's Rest Room (J-114) & Unaffected \\
\hline Men's Rest Room (J-116) & Unaffected \\
\hline Stairway \#7 (J-000) & Unaffected \\
\hline \hline
\end{tabular}

\subsubsection{Scope of Surveys}

7.2.3.2.1 Each area was divided into functionally similar survey units of floor-lower walls ( $<2 \mathrm{~m}$ above the floor surface), upper walls ( $>2 \mathrm{~m}$ above the floor surface) and ceilings.

7.2.3.2.2 Where a wall, floor or ceiling exhibited a discontinuity, it was categorized and surveyed as two different survey units.

7.2.3.2.3 The survey units were marked into $1 \mathrm{~m}^{2}$ grids as specified in Section 7.3 of this document. 


\subsection{Unaffected Areas}

- Survey coverage of unaffected areas was done by randomly selecting five floor grids and five lower wall grids. Each selected grid was scanned for beta-gamma with the survey instrument in rate mode. Five static measurements for total beta-gamma and alpha contamination, plus one waist-height exposure rate measurement and one wipe for loose beta-gamma and alpha contamination, were taken.

- No upper wall or ceiling surveys were performed in unaffected areas.

- $\quad$ No paint samples were taken in unaffected areas.

- All floor drains and wall penetrations were scanned for beta-gamma contamination and samples taken where practical. Samples were analyzed for gross alpha and beta contamination.

- Approximately $25 \%$ of the total surface area associated with overhead (e.g., light fixtures) and horizontal (e.g., vent ducts) surfaces were scanned for beta-gamma contamination with the survey instrument in rate mode. A wipe sample for loose alpha and beta surface contamination was taken on various sections of the overhead and horizontal surfaces.

\subsection{Low Probability Affected Areas}

- $100 \%$ of all floor area in the low probability affected group was scanned for beta-gamma contamination using a floor monitor in rate mode. The range of count rates during the survey was recorded.

- Areas where count rate increases of $50 \%$ or greater occurred were added as additional grids to the group of randomly selected grids designated for survey. A complete static survey measurement of the entire grid area was performed.

- In addition to any areas determined to have elevated readings during the floor scan, approximately $25 \%$ of all floor area grids were randomly selected. A five-point set of static measurements for both alpha and beta-gamma contamination/activation was performed.

- $\quad$ Approximately $25 \%$ of the lower walls in each area were gridded, and a five-point set of static measurements for both alpha and beta-gamma contamination/activation was made.

- Five grids within each of the remaining survey units (ceiling, upper walls) were selected, and a five-point set of static measurements for alpha and beta-gamma contamination/activation was made. 
- One loose surface contamination smear was taken in each of the grids surveyed. Smears were analyzed for alpha and beta contamination.

- One exposure rate measurement was performed (at waist height) in the middle of each selected grid.

- Ten paint samples were taken from the entire group of locations listed above and analyzed for gross alpha and beta-gamma contamination. A static measurement for alpha and beta-gamma contamination was done on each surface exposed after sampling.

- All drain surfaces and penetrations were scanned for beta contamination and samples were taken where practical. All samples were analyzed for gross alpha and beta-gamma contamination.

- Approximately $25 \%$ of the total surface area comprising overhead and vent ducts was scanned for beta-gamma contamination with the survey instrument in rate mode. Surface contamination smears were taken on various sections of these areas and analyzed for gross alpha and beta contamination.

- Electrical strips and outlet boxes were scanned for beta contamination. Scans included both external and internal areas. Surface contamination smears were performed on selected electrical boxes.

- Additional surveys (biased locations) were performed on areas selected by the Radiological Controls Supervisor. The criterion used for selection was the possible presence or accumulation of radioactive material.

- $\quad$ Elevated spots ( $>50 \%$ of background count rate) detected during scan surveys, static measurements, or as a result of sample analyses, were evaluated; a reasonable attempt was made to decontaminate these areas.

\subsection{High Probability Affected Areas}

- $100 \%$ of all floor areas in the high probability affected group was scanned for betagamma contamination using a floor monitor in scan integral mode; results were recorded as average activity per grid.

- No five-point static measurements for floor and lower wall grids was required due to the instrument's scan integral mode of operation. This mode of operation yields an estimate of the average surface activity per $100 \mathrm{~cm}^{2}$ within each grid.

- Approximately $25 \%$ of the upper walls were gridded and a five-point set of static measurements for beta-gamma contamination/activation performed. 
- Five ceiling grids in each area were marked and a five-point set of static measurements for beta-gamma contamination/activation performed.

- One surface contamination smear was taken in each grid area surveyed above and analyzed for gross alpha and beta-gamma contamination.

- $\quad$ Five paint samples were taken from each survey area and analyzed for gross alpha and beta-gamma contamination. A static measurement was performed for alpha and betagamma contamination on each surface exposed after sampling.

- All drain surfaces and penetrations were scanned for beta contamination and samples taken where practical. All samples were analyzed for gross alpha and beta-gamma contamination.

- Approximately $25 \%$ of the total surface area comprising overhead and vent ducts was scanned for beta-gamma contamination with the survey instrument in rate mode. Surface contamination smears were taken on various sections of these areas and analyzed for gross alpha and beta contamination.

- Electrical strips and outlet boxes were scanned for beta contamination. Scans included both external and internal areas. Surface contamination smears were performed on selected electrical boxes.

- Exposure rate surveys were made in each survey area; one measurement was made for each $4 \mathrm{~m}^{2}$ of floor area.

- Additional surveys (biased locations) were performed on areas selected by the Radiological Controls Supervisor. Criteria for selection was the possibility of a presence or accumulation of radioactive material.

- Elevated spots ( $>50 \%$ of the background count rate) detected during scan surveys, static measurements, or as a result of samples performed, were evaluated; a reasonable attempt was made to decontaminate these areas.

\subsection{Reference Grid System}

A grid system was used to reference the location of samples and measurements within the JANUS Reactor facility. Survey units containing affected areas were divided into $1 \mathrm{~m}^{2}$ intervals (grids). The floor grid pattern used alphabetical coordinates along the east-west axis and numerical coordinates along the north-south axis. Floor-to-ceiling wall grids were identified from top to bottom with Roman numerals I, II, III, IV, and all wall grids were prefixed by a floor-grid identifier. All ceiling and overhead grids were referenced using the existing floor coordinate subsystem. Maps were prepared of each survey unit showing grid numbers and locations. Measurements taken in 
unaffected areas were referenced using prominent building features and grid numbers from nearby affected areas. The location of each survey point in an unaffected area was marked with a permanent marker and noted on the appropriate survey map.

\subsection{Survey Instrumentation}

\subsubsection{Instrument Selection}

To provide a detection sensitivity of approximately $25 \%$ or less of the approved release criteria for total and removable radioactivity measurements, the most appropriate combination of instrumentation, background count time, field count time and survey technique were considered. All instruments were required to be calibrated to NIST-traceable standards. Efficiencies were determined on-site using laboratory standards that were also NIST-traceable. Daily source and background checks were made throughout the survey work to ensure accurate readings.

\subsubsection{Background Determinations}

Background determinations were made by taking measurements at locations on or near the site which had been unaffected by site operations. Instrument reference response readings to levels of naturally occurring background radiation in non-radiological areas were determined for exposure rates and contamination levels. Readings for gross alpha and beta contamination activity for removable contamination were not determined for these reference response levels.

\subsubsection{Daily Instrument Function Test and Quality Assurance}

Each instrument used during the final survey was tested a minimum of once each day prior to use, and the results of each test were recorded on an instrument test sheet. The instrument test comprised background readings, source checks to determine instrument efficiency, and periodic response checks to ensure proper functioning. All test results were recorded and reviewed by the Radiological Controls Supervisor, and all records were made part of the final survey package.

\subsection{Survey Methodology}

\subsubsection{Surface Scan}

Surface scans were used to identify any locations having residual surface activity. The type and extent of the surface scan performed was dependent upon the following:

- $\quad$ Affected areas - scan $100 \%$ of the surface.

- Surfaces above affected areas - scan the area in the vicinity of each point measurement. 
- Unaffected floors and lower walls - scan $25 \%$ of the surface.

Building interior surfaces were scanned for beta-gamma activity. Scanning rates were limited to $3 \mathrm{sec}$ per probe area (i.e., if surveying with a $550 \mathrm{~cm}^{2}$ probe, it should take approximately $55 \mathrm{sec}$ to scan a $1 \mathrm{~m}^{2}$ grid). As a rule, the most sensitive instrument available was used for scanning unless restricted by the physical surface of the area or portability of the instrument.

\subsubsection{Direct Measurements}

Direct measurements were taken in selected areas:

- Affected areas (high probability) - A single static measurement was taken for total alpha contamination within each floor and lower wall grid of each area.

- Affected areas (low probability) - Five static measurements were taken for total alpha and beta-gamma contamination within $25 \%$ of the floor and lower wall grids of each area.

- Unaffected areas - Five static measurements were taken for total alpha and beta-gamma contamination within five floor and five lower wall grids in each unaffected area.

- Upper walls and ceilings - Five static measurements were taken for total alpha and betagamma contamination in five upper wall grids and five ceiling grids in each area.

\subsubsection{Removable Contamination Measurements}

One $100 \mathrm{~cm}^{2}$ wipe for removable contamination was taken in each grid surveyed. All wipes were analyzed for both alpha and beta-gamma activity.

\subsubsection{Exposure Rate Measurements}

Gamma exposure rate measurements were taken $1 \mathrm{~m}$ from the surface. Measurements were uniformly spaced according to the following criteria:

- Affected areas - one measurement per $4 \mathrm{~m}^{2}$ of floor area.

- Unaffected areas - one measurement at each randomly selected grid on floor and lower wall surfaces. 


\subsubsection{Special Measurements and Sampling}

\subsubsection{Paint Samples}

Samples, i.e., $100 \mathrm{~cm}^{2}$ paint scrapings, were taken from the following areas and analyzed for gross beta and alpha activity.

- $\quad$ Affected areas (high probability) - Five paint samples were taken from each area.

- Affected areas (low probability) - A total of 10 paint samples were taken from all areas.

- Unaffected areas - No paint samples were taken.

\subsubsection{Electrical Boxes}

All electrical boxes were opened and direct measurements taken for total beta and alpha surface contamination. In addition, several boxes from each area were smeared for loose alpha and betagamma contamination.

\subsubsection{Concrete Samples:}

Three concrete samples were taken from the north, south and floor areas directly in line with the center line of the core after removal of the biological shield concrete.

\subsubsection{Drain Surfaces and Penetrations}

All drain surfaces and penetrations were scanned for beta contamination, and samples were taken where feasible. These samples were analyzed for gross alpha and beta-gamma contamination.

\section{Interpretation of Survey Results}

Data conversions and evaluations were performed following guidance provided in NUREG/CR-5849 and the JANUS D\&D Project Final Status Survey Plan.

\subsection{Final Survey Results}

All accessible areas within J-Wing met the ANL-E release criteria except the following areas: The reactor cavity and high-dose room were sealed by constructing a concrete block wall at the low-dose room face, installing floor plugs above the reactor cavity and high-dose room, and closing the highdose room shield door. These areas were posted as controlled areas. Access will be restricted until residual activity has decayed to acceptable levels or until the building is demolished, whichever occurs first (see Section 11 for more information). 


\section{8}

\section{Independent Verification Survey}

During November 1997, ORISE will perform an IVS of J-Wing to verify the results of the contractor's final verification survey.

\subsection{Post D\&D Hazardous Material Condition}

All hazardous materials were removed from J-Wing and transferred to the appropriate ANL-E division for reuse or disposal with the exception of inaccessible lead-based paint remaining on the steel casings and support beams inside the floor openings.

\subsection{HEALTH AND SAFETY}

\subsection{Industrial Health and Safety}

It is the policy of ANL-E to protect the safety and health of employees, subcontractors, members of the general public and the environment by taking all reasonable precautions during the performance of a D\&D project. Strict compliance with all applicable environmental, safety and health regulations and requirements, including DOE reporting requirements, is essential. During the duration of the JANUS D\&D Project, safety took precedence over production. A principal objective of the project was to complete the D\&D of the Janus Reactor facility in a timely manner while maintaining the highest standards for safety and health. The project-specific Environment, Safety and Health Plan provided the guidance necessary to perform all work in a safe manner.

A pre-job hazard evaluation was performed which identified as many of the known potential hazards as possible. Some of the hazards identified were operation of heavy equipment, lifting and rigging, noise, falling objects, eye hazards, radiation exposure, pinch points, confined space entry work, fire hazards, electrical shocks, heat stress and exposure to hazardous chemicals. A hazard communication program was implemented which kept workers informed and aware of potential hazards. Frequent inspections by ANL-E Safety Engineering personnel, as well as ANL-E and subcontractor oversight personnel, were performed to ensure employee awareness and compliance with established safety regulations.

During the course of the project, Afftrex, Ltd. employees worked a total of $18,173.5$ hours at the JANUS D\&D Project site. Only one OSHA 200 recordable injury case occurred with no lost work days for the entire project. The recordable case consisted of a fractured and lacerated finger (the finger had been pinched between concrete and a jackhammer during concrete removal operations). The Afftrex employee received immediate medical treatment and returned to work the same day. A formal injury inquiry report was prepared and reviewed with all project staff.

The excellent safety performance at the JANUS D\&D project was due to the commitment of ANL-E project staff and Afftrex employees to perform their jobs in a safe and professional manner. Daily 
toolbox meetings and weekly safety meetings provided the necessary forum for keeping the project staff apprised of potential hazards and unusual situations. Training, including periodic refresher courses, provided the necessary operational and safety information to allow project staff to perform their jobs in accordance with required standards.

\subsection{Radiation Protection}

The presence of radioactive materials presented a radiological hazard to the workers, general public and the environment. The JANUS D\&D Project Radiological Control Plan provided the necessary guidance with which to perform work in a radiologically safe manner. The ALARA (As Low As Reasonably Achievable) philosophy was used throughout the project. Only trained, essential personnel were used during the performance of the project. ALARA reviews were made prior to the start of on-site work and prior to the start of each segment of work that involved personnel exposure.

Engineering controls, such as HEPA ventilation and containment tents, were used whenever possible to limit personnel exposure. Fersonnel protective equipment was also used to limit worker exposure to loose and airborne contamination. Signs and barriers were posted to keep unauthorized personnel from entering radiation and/or contamination areas and to inform workers about entry requirements and radiological conditions inside the area. To prevent the spread of contamination, all equipment, tools and personnel leaving a controlled area were monitored for radioactive contamination at the exit point.

Radiological Work Permits (RWP's) were utilized for all phases of work. The RWP's specified the radiological conditions in the area, and requirements for safety and protective equipment, personnel monitoring equipment and sampling. Each individual working in the JANUS facility was required to read, understand and sign the specific RWP under which they were working. Radiation exposure was monitored with thermoluminescent dosimeters (TLDs), bioassay analyses and whole body counting. Self reading dosimeters (SRD's) were worn by all individuals to track exposure on tasks performed in radiation-posted areas.

Specialized radiation protection was utilized. Continuous air monitors (CAM's) were placed near work areas which sounded an alarm if high airborne radioactivity existed. Grab samplers and lapel samplers were placed in a worker's breathing zone to track personnel exposure to airborne activity. Respiratory protection was required when exposure to airborne levels of $10 \%$ derived airborne concentration (DAC) or higher was expected.

There were no personnel contaminations or over exposures throughout the JANUS D\&D Project.

\subsection{Project Exposure Summary}

A project dose estimate made prior to the start of on-site activities was used to determine project staffing and tracking of actual-to-planned project exposure. The ANL-E administrative limit of $1.0 \mathrm{rem}$ per individual per year was adopted as the project administrative limit. No individual 
exceeded the ANL-E administrative limit during the project. Total project exposure was estimated to be 2.856 person rem $(28.56 \mathrm{mSv})$. Actual exposure for the project was 0.482 person rem $(4.82 \mathrm{mSv})$.

\subsection{WASTE MANAGEMENT}

\subsection{Waste Types}

Material removed from the JANUS Reactor facility was separated into five categories: low-level radioactive waste, mixed waste, hazardous waste, recoverable material and clean scrap.

- Low-level radioactive waste was packaged and transferred to WMO for shipment to a licensed off-site disposal facility.

- Mixed waste (material that contained both hazardous or characteristic-hazardous materials combined with radioactive materials) was packaged and transferred to WMO for further processing and/or storage at ANL-E.

- Hazardous waste (asbestos and small quantities oil) was packaged and disposed of at a licensed facility or processed at ANL-E.

- Recoverable material (clean lead or slightly activated lead $(<0.1 \mathrm{mR} / \mathrm{hr}(<1 \mu \mathrm{Sv} / \mathrm{hr}))$ was transferred to the ANL-E lead bank or transferred to WMO for future use at other ANL-E projects.

- Clean scrap (equipment and materials removed from the JANUS facility) was sent to a local recycling center for sorting and disposition.

Afftrex was responsible for packaging waste in accordance with ANL-E, DOE-Hanford and Department of Transportation (DOT) regulations. Disposition of all materials was the responsibility of ANL-E.

\subsection{Waste Volumes}

A summary of waste and recoverable materials removed during the JANUS D\&D Project is shown in Table 9.1. Waste volumes are shown graphically in Figure 9.1, and waste volume details are provided in Appendix I. 
JANUS D\&D Project

Final Report

Page 86 of 111

Table 9.1 Waste and Recoverable Material Removed From the JANUS Reactor Facility

\begin{tabular}{||l|c|c|c|}
\hline \multicolumn{1}{|c|}{ Type of Material } & $\begin{array}{c}\text { Volume } \mathbf{f t}^{\mathbf{3}} \\
\left(\mathbf{m}^{\mathbf{3}}\right)\end{array}$ & $\begin{array}{c}\text { Weight lb. } \\
(\mathbf{k g})\end{array}$ & $\begin{array}{c}\text { Activity mCi } \\
(\mathbf{G B q})\end{array}$ \\
\hline \hline Low-Level Radioactive Waste & $\begin{array}{c}4,002.1 \\
(113.3)\end{array}$ & $\begin{array}{c}343,337.7 \\
(155,738.0)\end{array}$ & $\begin{array}{c}3,132.9 \\
(115.9)\end{array}$ \\
\hline Mixed Waste & $\begin{array}{c}538 \\
(15.2)\end{array}$ & $\begin{array}{c}47,023.8 \\
(21,330.0)\end{array}$ & $\begin{array}{c}168.0 \\
(6.2)\end{array}$ \\
\hline Asbestos & $\begin{array}{c}513 \\
(14.5)\end{array}$ & N/A & N/A \\
\hline Recoverable Lead & $\begin{array}{c}327 \\
(9.3)\end{array}$ & $\begin{array}{c}41,600.5 \\
(18,870.0)\end{array}$ & $\begin{array}{c}2.4 \\
(.09)\end{array}$ \\
\hline Clean Lead & $\begin{array}{c}291 \\
(8.2)\end{array}$ & $\begin{array}{c}207,230 \\
(93,999.5)\end{array}$ & N/A \\
\hline Clean Scrap & $\begin{array}{c}(5,130 \\
(145.3)\end{array}$ & $(40,489$ \\
\hline Hazardous Materials & 2.1 & 50 & N/A \\
\hline
\end{tabular}

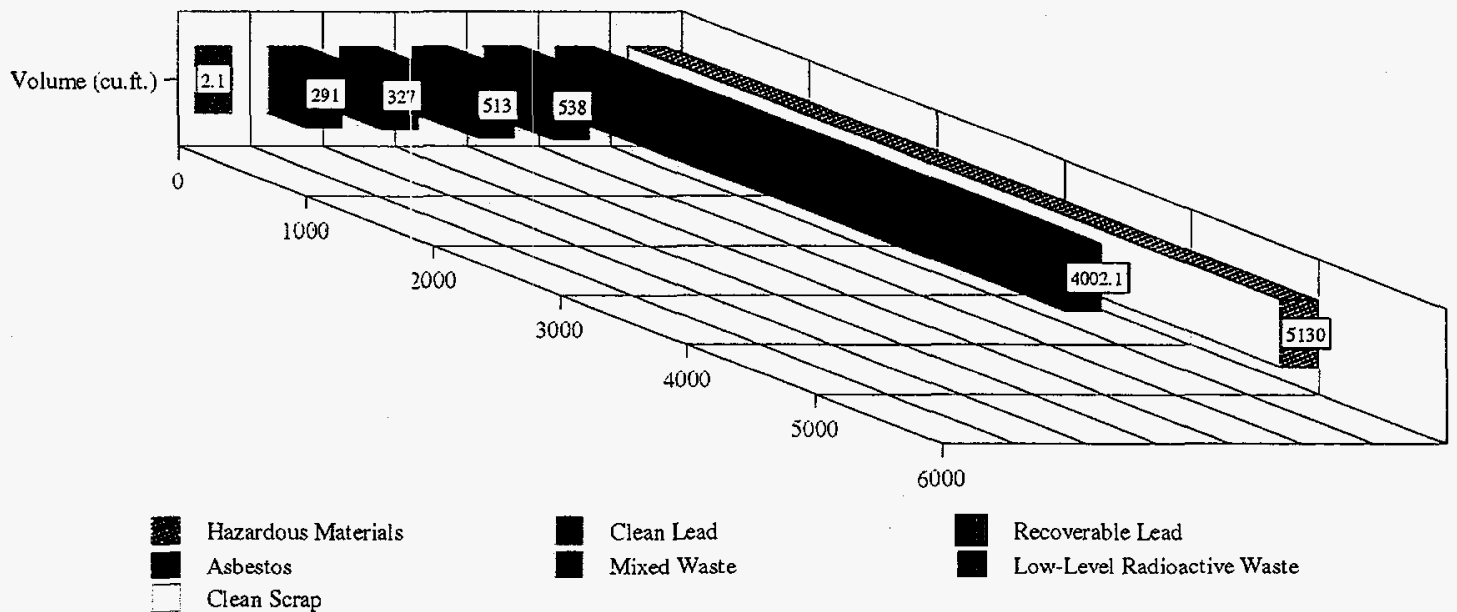

Figure 9.1 Waste Removed from JANUS Reactor Facility 


\subsection{Waste Packaging}

Waste packaging operations conformed with ANL's Waste Handling Procedures Manual, U.S. Department of Transportation (49CFR) regulations and requirements of the designated disposal site.

- Low-level and mixed waste - standard ANL-E M-3A 1/2 Bins, Afftrex-supplied B-25 and B-12 metal boxes, $17 \mathrm{H} 55$ gal (208.18 1) drums and a special $5 \mathrm{ft}^{2}\left(152.4 \mathrm{~cm}^{2}\right)$ metal box were loaded, sealed and transferred to WMO final disposition.

- Clean scrap - roll-off containers supplied by the recycling vendor were packaged and disposed of at a local recycling center.

- $\quad$ Asbestos waste - waste was double bagged and deposited in covered roll-off containers supplied by WMO and disposed of.

- $\quad$ Liquid Hazardous Waste - small quantities of liquid hazardous waste (mercury, oil and lead-contaminated water) were packaged in 5 gal (18.9 1) cans and transferred to WMO for disposition.

\section{$9.4 \quad$ Waste Transport}

Transportation of project waste was the responsibility of WMO. Waste packages were prepared for shipment by Afftrex and delivered to WMO for final disposition. 


\subsection{COST AND SCHEDULE}

\subsection{JANUS D\&D Project Cost}

The JANUS Reactor D\&D Project was funded by the U. S. Department of Energy Assistant Secretary for Environmental Management Office of Environmental Restoration (EM-40) and completed for a total cost of approximately $\$ 2,095,000$. Figure 10.1 provides a project cost breakdown of major components. Each major cost component is shown as a percentage of total project cost.

\section{JANUS PROJECT}

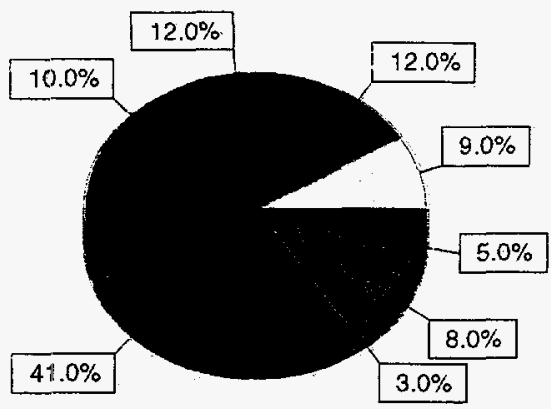

Program Management

Surveillance \& Maintenance

$D \& D$

Waste
Drogram Engineering

- Characterization

Equipment \& Materials

Closeout

Figure 10.1 JANUS D\&D Project Total Cost Breakdown 


\subsection{JANUS D\&D Project Schedule}

The JANUS Reactor D\&D Project began in October 1995 and finished in December 1997, a total of 27 months. Actual on-site work started in January 1997 and was completed in September 1997. The JANUS D\&D Project Schedule is shown in Figure 10.2.

\subsection{FINAL FACILITY CONDITION}

Afftrex completed all on-site D\&D activities in late September 1997. All areas met the free release criteria with the exception of the high-dose room and the reactor cavity. The steel cladding on the concrete "brow" of the east side of the reactor cavity was activated, and dose rates as high as $1.5 \mathrm{mrem} / \mathrm{hr}(15 \mu \mathrm{Sv} / \mathrm{hr})$ were detected on contact with the steel-cladded brow. The high-dose room walls, floor and door were activated to depths in excess of 15 in $(38.1 \mathrm{~cm})$.

The facility condition was discussed between ANL-E and DOE management. The removal of these activated components would compromise the building structure, and a large renovation cost would be incurred to bring the building into compliance with existing building codes. After alternatives were reviewed, it was decided that these areas would be isolated from personnel access by constructing a concrete block wall across the low-dose face, installing the reactor area and high-dose area floor plugs and closing the high-dose room door. ESH/HP posted signs to alert personnel of the residual activity. Figures 11.1 and 11.2 provide annual dose projections for the high-dose room and the reactor cavity.

The remainder of the facility was free released for unrestricted access and made available for occupancy.

All systems and components associated with reactor operation have been removed. These included primary and secondary coolant systems, reactor helium systems, reactor water purification and water storage systems, reactor control systems, the biological shield and the reactor. The ventilation system was not contaminated and left in place. The $75 \mathrm{ft}(22.88 \mathrm{~m})$ tall exhaust stack was removed and capped at a height of about $5 \mathrm{ft}(1.55 \mathrm{~m})$ above the roof.

Figures 11.3 - 11.9 show the JANUS Reactor facility at completion of D\&D activities. 


\begin{tabular}{|c|c|c|c|c|c|c|c|c|}
\hline \multicolumn{9}{|c|}{$\begin{array}{c}\text { JANUS D\&D PROJECT } \\
\text { Argonne National Laboratory }\end{array}$} \\
\hline & & & & 35 & 1996 & 1997 & & \\
\hline ID & Task Name & Start & Finish & \begin{tabular}{l|l} 
Q3 & Q4 \\
\end{tabular} & \begin{tabular}{l|l|l|l|}
$\mathrm{Q} 1$ & $\mathrm{Q} 2$ & $\mathrm{Q} 3$ & $\mathrm{Q} 4$ \\
\end{tabular} & \begin{tabular}{l|l|l|}
$\mathrm{Q} 1$ & $\mathrm{Q} 2$ & $\mathrm{Q} 3$ \\
\end{tabular} & Q4 & Q1 \\
\hline 1 & JANUS D\&D PROJECT & 10/2/95 & $12 / 22 / 97$ & $\triangle$ & & & 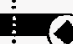 & \\
\hline 2 & Project Management and Staff & $10 / 2 / 95$ & $10 / 3 / 97$ & & & & & \\
\hline 3 & Engineering and Procedure Support & $10 / 2 / 95$ & $9 / 30 / 97$ & & & & & \\
\hline 4 & Equipment and Materials & $10 / 2 / 95$ & $9 / 30 / 97$ & & & & & \\
\hline 5 & Characterization & $12 / 21 / 95$ & $5 / 30 / 96$ & & $=$ & & & \\
\hline 6 & Procurement Activities & 6/3/96 & $11 / 12 / 97$ & & & & & \\
\hline 7 & Contractor Mobilization & $11 / 11 / 96$ & $1 / 21 / 97$ & & & & & \\
\hline 8 & Surveillance and Maintenance & $1 / 6 / 97$ & $9 / 30 / 97$ & & & & & \\
\hline 9 & Decommission Facilities & $1 / 22 / 97$ & 9/23/97 & & & & & \\
\hline 10 & High- and Low-Dose Shutter System Removal & $1 / 22 / 97$ & 9/9/97 & & & & & \\
\hline 11 & Miscellaneous Components & $1 / 28 / 97$ & $9 / 23 / 97$ & & & & & \\
\hline 12 & Control Room Facilities Removal & $1 / 29 / 97$ & $3 / 4 / 97$ & & & a & & \\
\hline 13 & High-Dose Room Demolition & $2 / 3 / 97$ & $4 / 15 / 97$ & & & & & \\
\hline 14 & Reactor Area Demolition & $2 / 27 / 97$ & $9 / 9 / 97$ & & & & & \\
\hline 15 & Systems Removal & $3 / 4 / 97$ & $5 / 7 / 97$ & & & & & \\
\hline 16 & Storage Facilities and Excess Material & $3 / 5 / 97$ & $7 / 23 / 97$ & & & & & \\
\hline 17 & Activated Structure Removal & 3/19/97 & $9 / 10 / 97$ & & & & & \\
\hline 18 & Close-Out Operations & $5 / 8 / 97$ & $12 / 22 / 97$ & & & & & \\
\hline
\end{tabular}




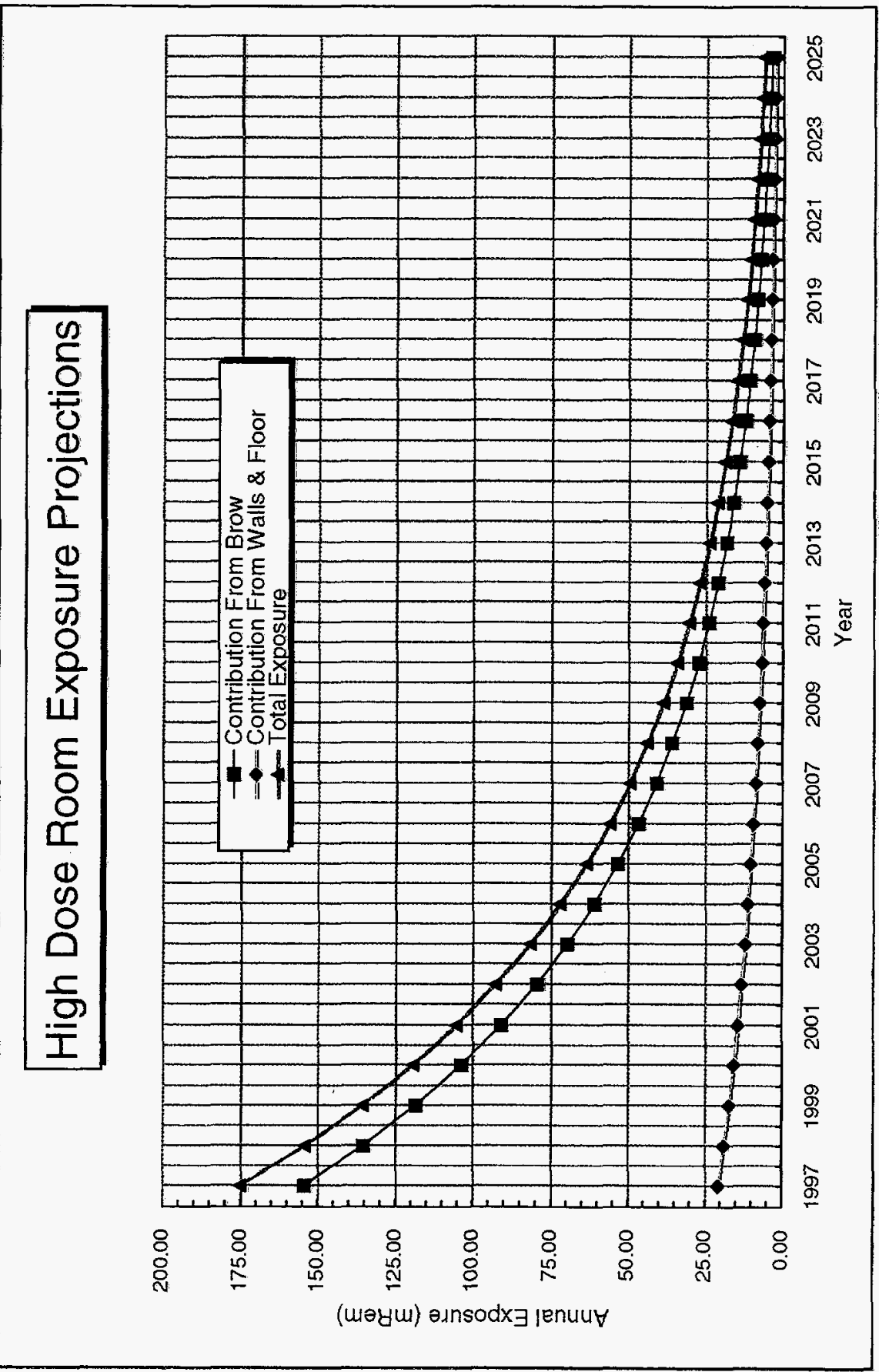

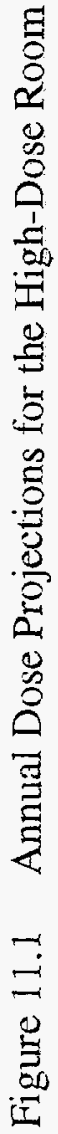




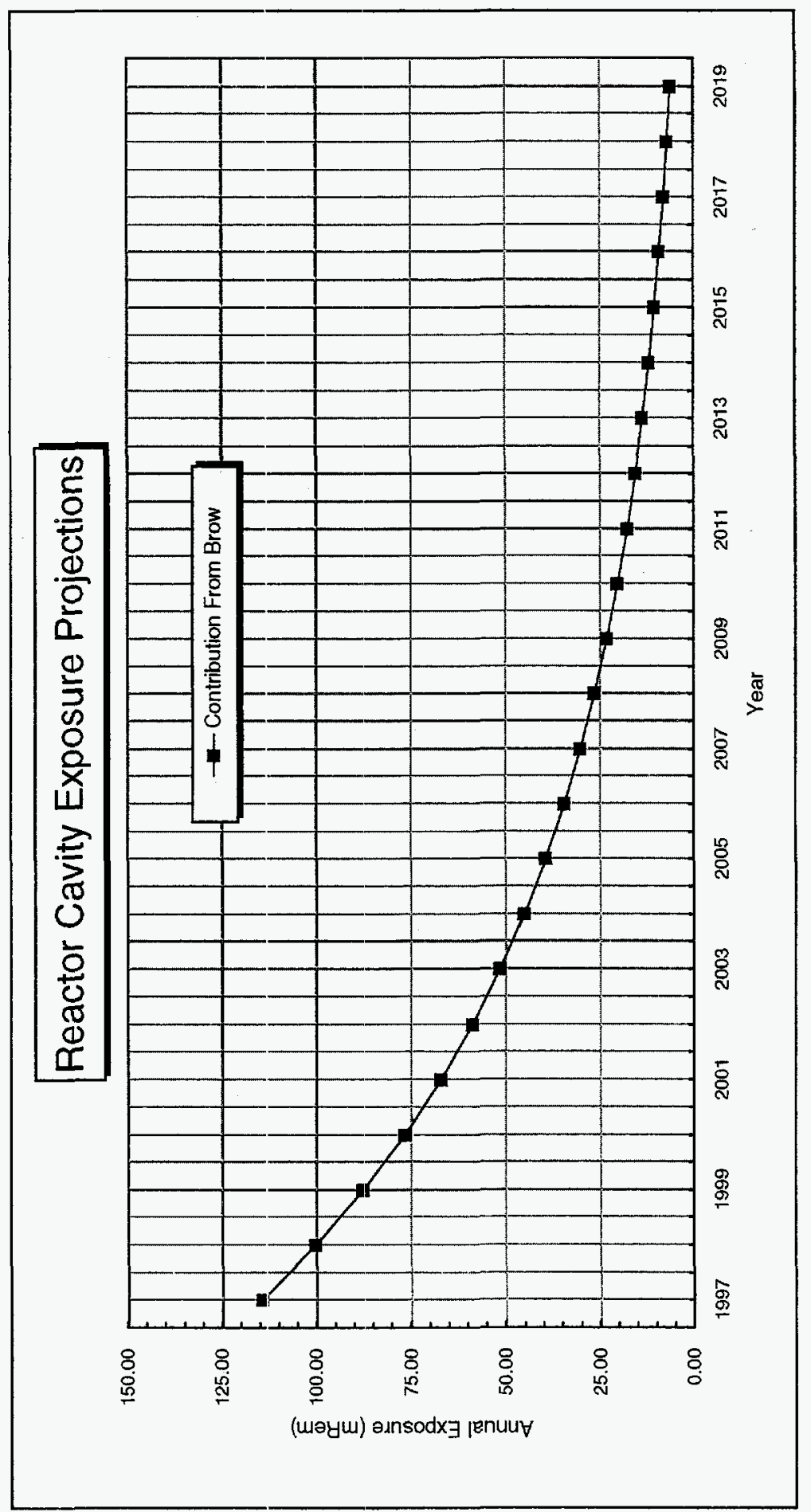

帒 
JANUS D\&D Project

Final Report

Page 93 of 111

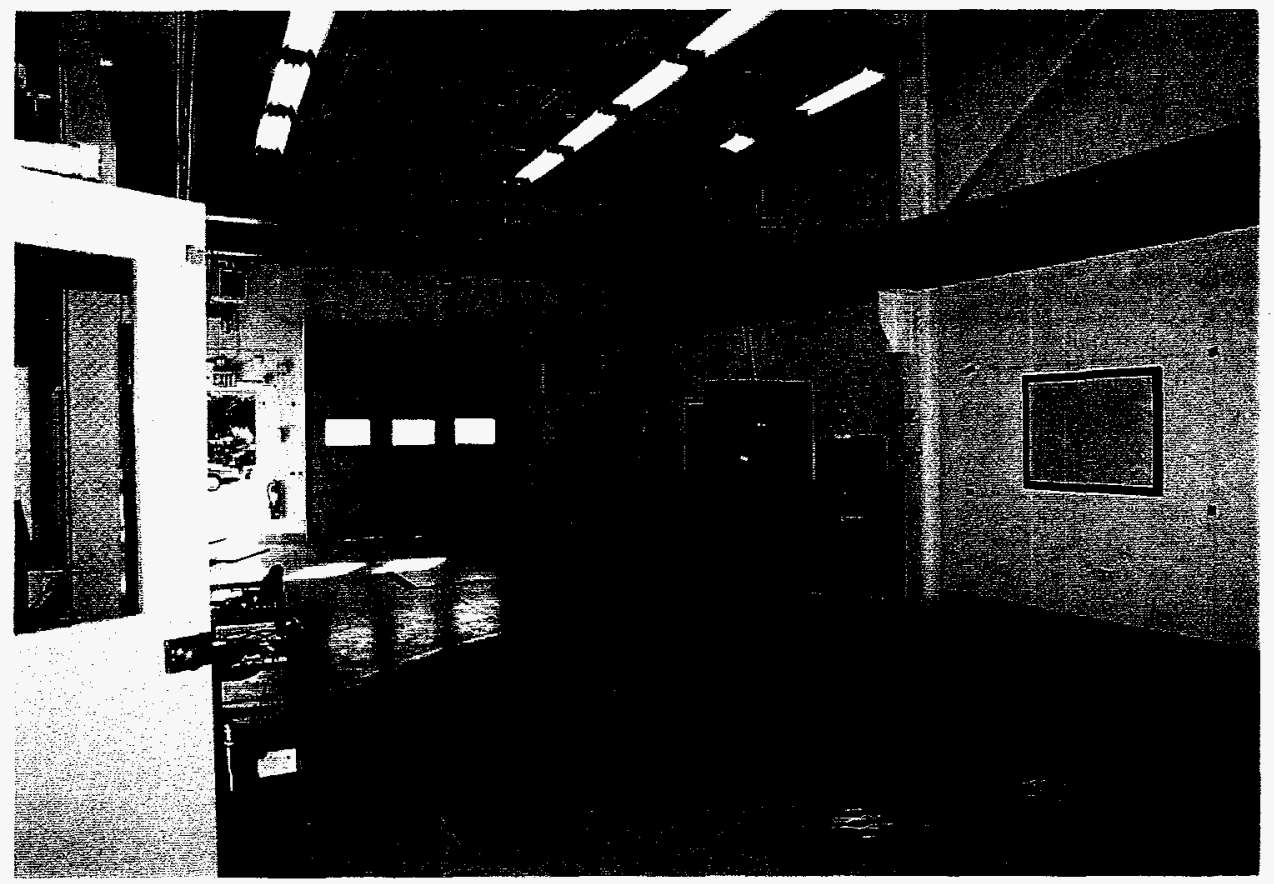

Figure 11.3 High Bay Looking East (Room J-105)

(ANL Negative \#23612K, Frame \#2A)

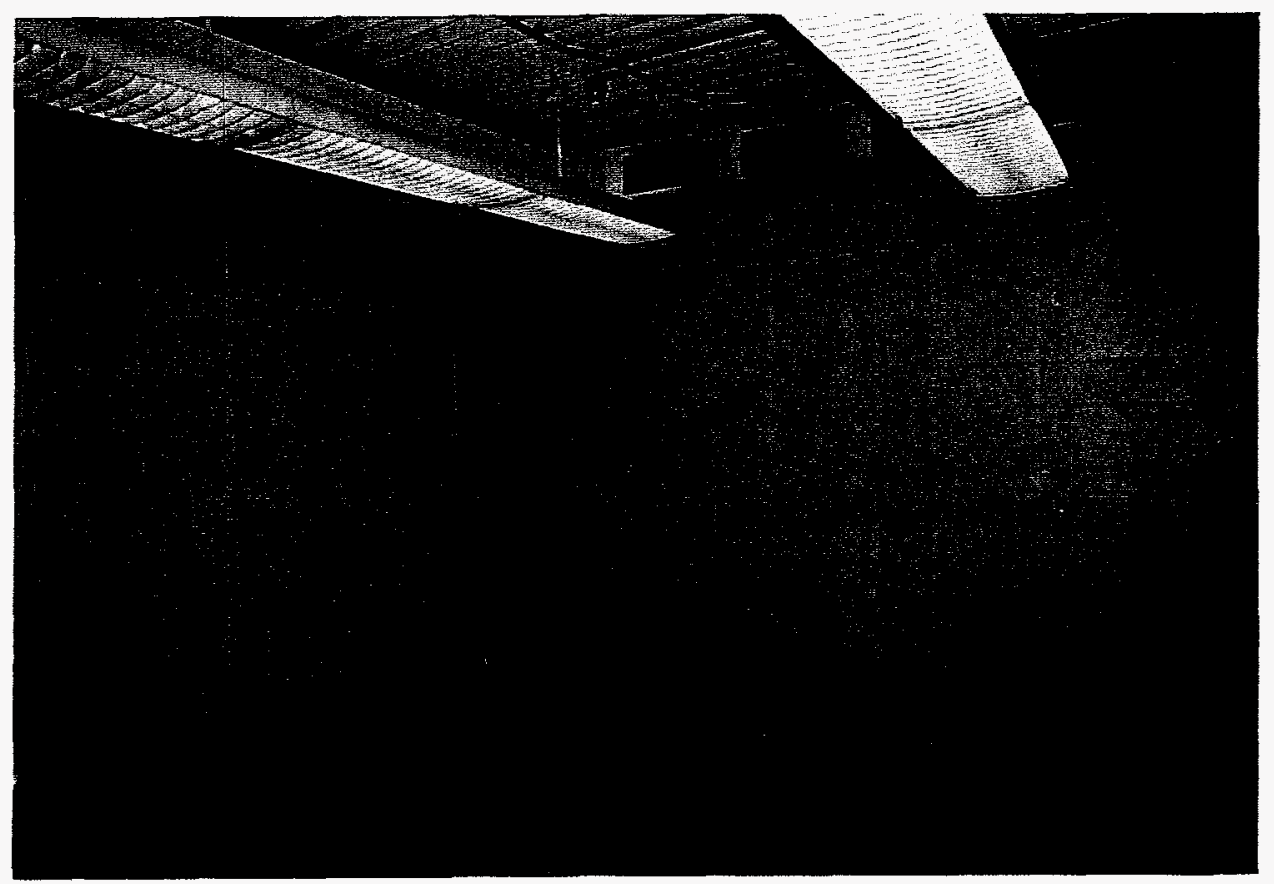

Figure 11.4 Reactor Control Room Looking East (Room J-112) (ANL Negative \#23612K, Frame \#4A) 


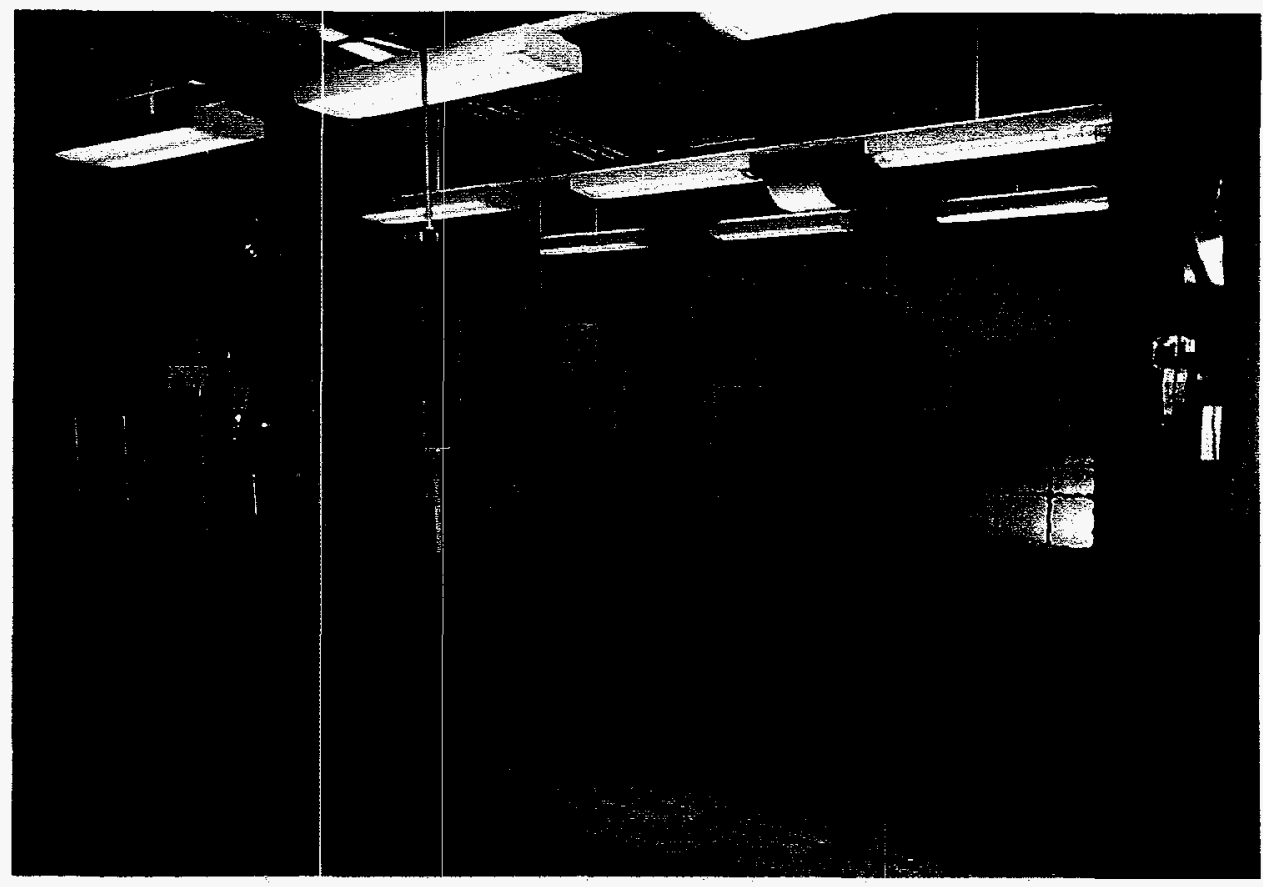

Figure 11.5 Low-Dose Preparation Room Looking East (Room J-014) (ANL Negative \#23612K, Frame \#17A)

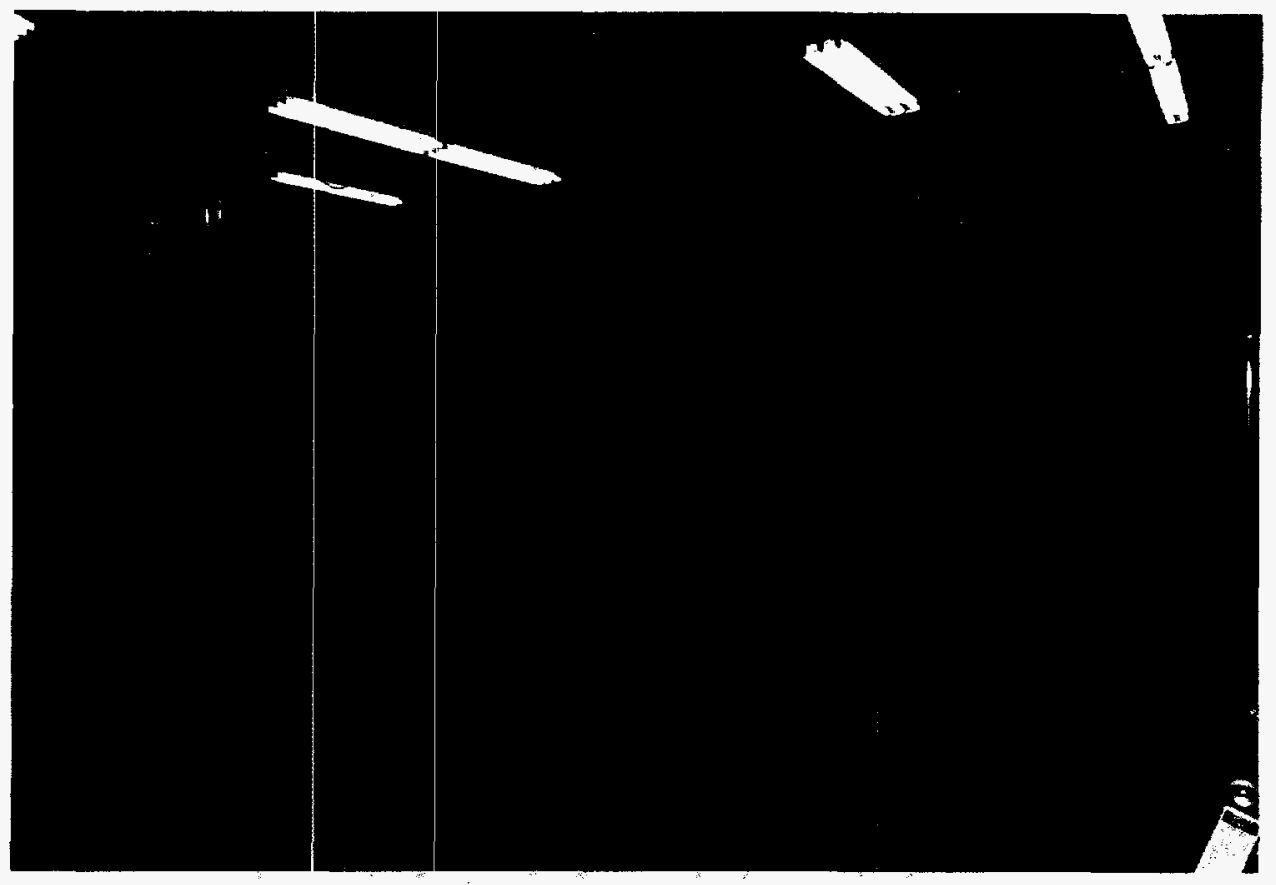

Figure 11.6 Low-Dose Room Looking West (Room J-015) (ANL Negative \#23612K, Frame \#20A) 


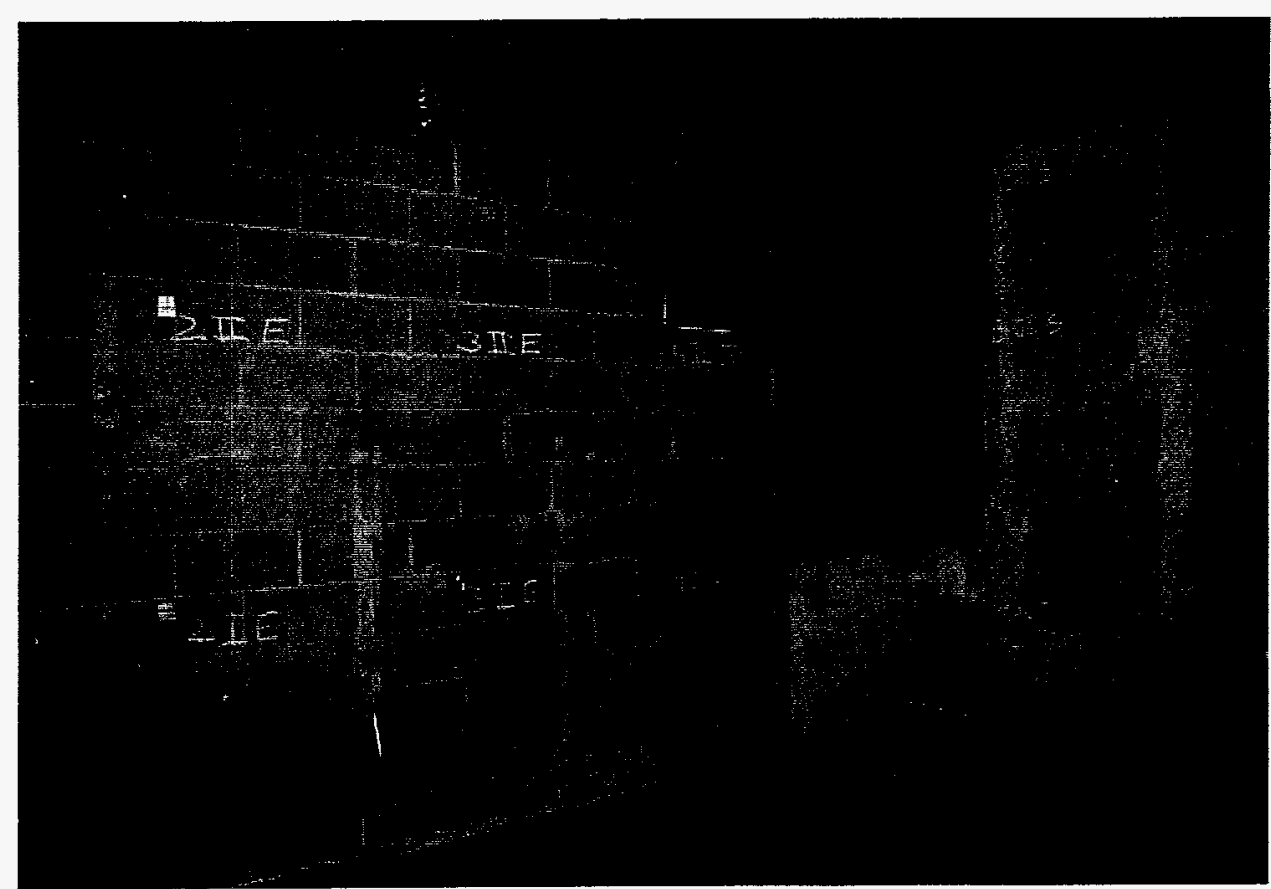

Figure 11.7 Reactor Equipment Room Looking South (Room J-010) (ANL Negative \#23612K, Frame \#11A)

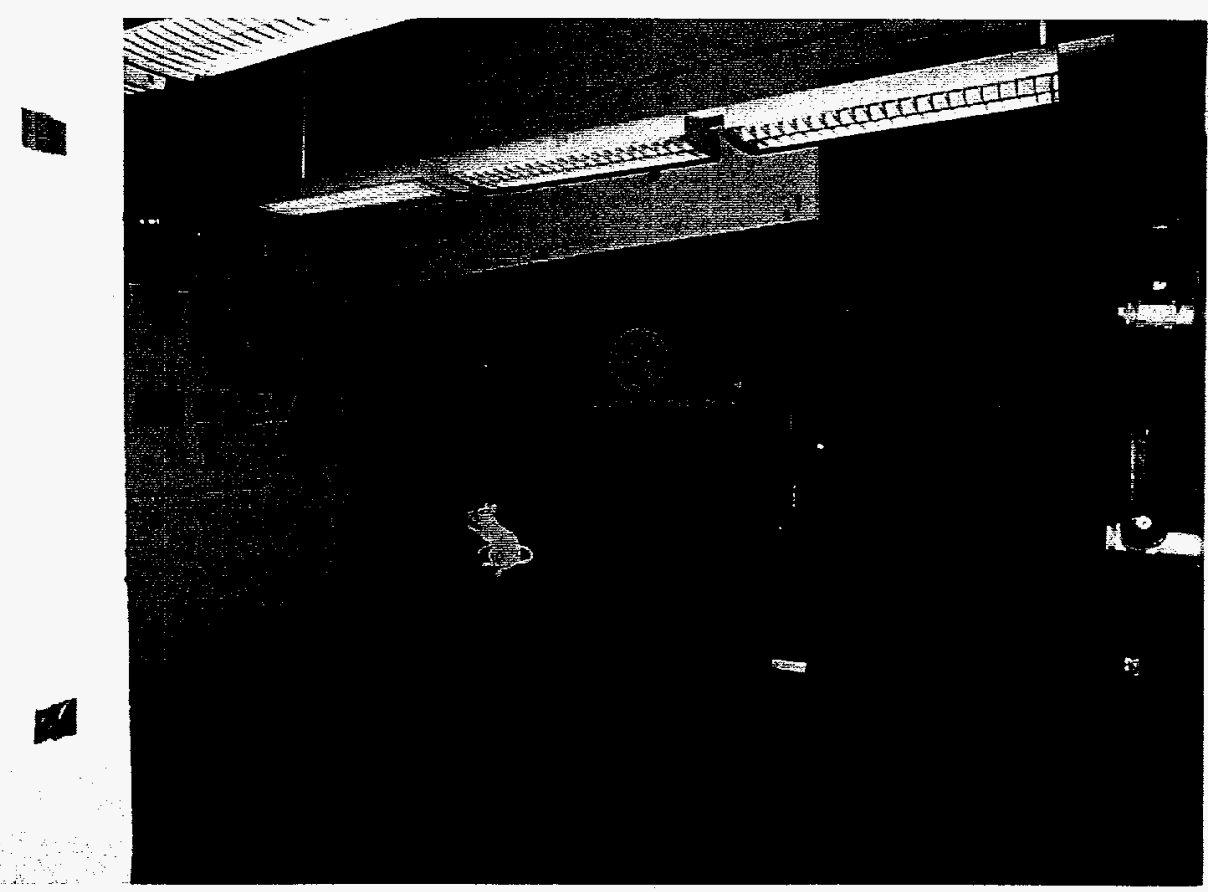

Figure 11.8 High-Dose Preparation Room Looking South (Room J-002) (ANL Negative \#23612K, Frame \#10A) 


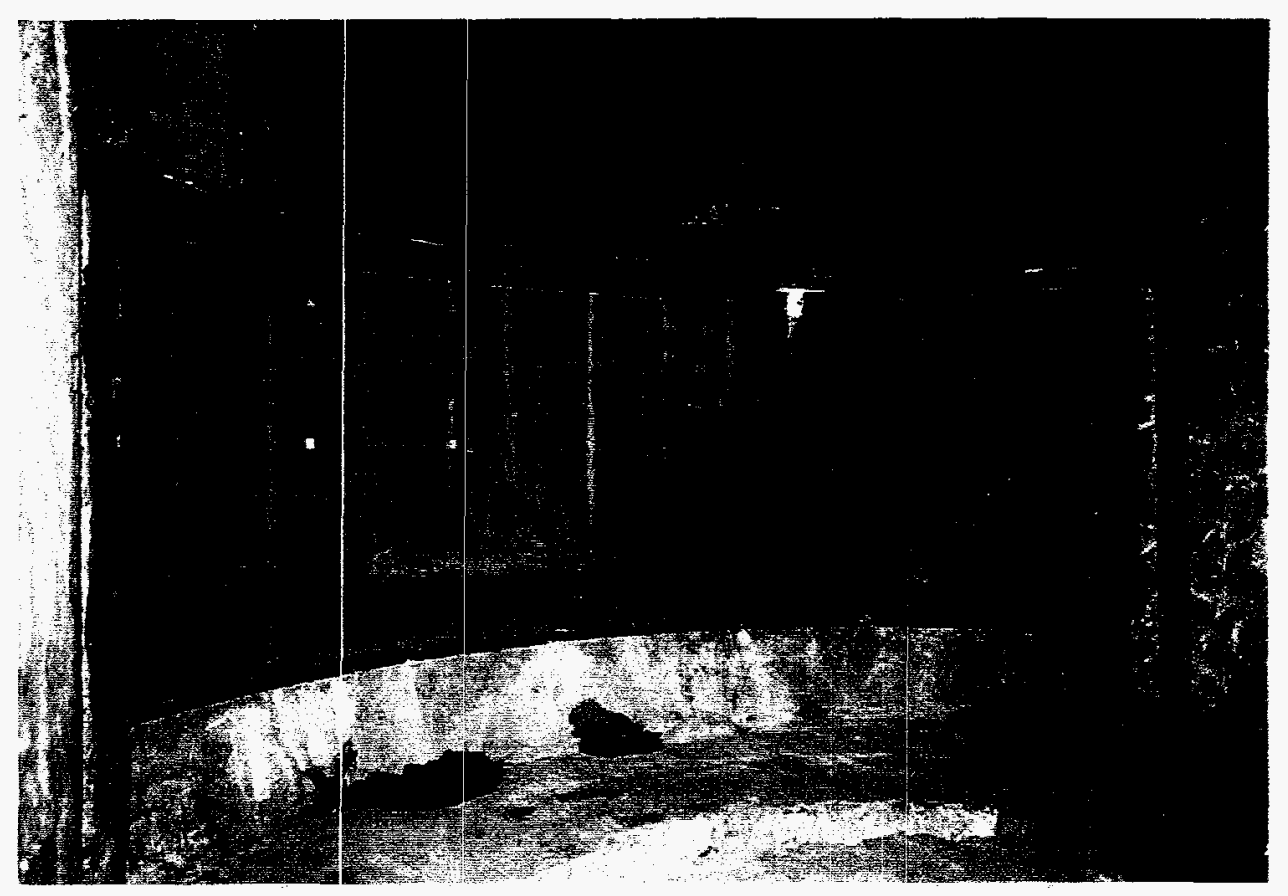

Figure 11.9 Reactor Cavity and High-Dose Room Looking West (Rooms J-200 and J-007) (ANL Negative \#23612K, Frame \#14A) 


\section{CONCLUSIONS, RECOMMENDATIONS AND LESSONS LEARNED}

The completion of the JANUS D\&D project permitted the transfer of the JANUS Reactor facility from the U.S. Department of Energy EM-40 roster to ANL-E surplus facilities. With the exception of the high-dose room and reactor cavity, the facility has been free-released for unrestricted use and made available for immediate reuse. It is recommended that the high-dose room and reactor cavity be isolated and posted as controlled areas until residual activity has decayed to acceptable levels or until Building 202 is dismantled.

\subsection{General Problems Encountered and Lessons Learned}

It is not unusual during projects of this magnitude to encounter unforseen problems, to increase knowledge through new experiences and to make noteworthy discoveries. Incorporation of important lessons learned into the planning and execution of future D\&D projects may improve worker safety, eliminate unnecessary project cost and enhance schedule completion. The following lessons learned from the JANUS D\&D project are provided so that future D\&D projects may benefit.

\subsubsection{Cutting Live Wires}

Early in the project, two live wires were cut while dismantling the reactor control panels: After performing LO/TO on all identified circuits to the reactor control panels, technicians verified the procedure by performing voltage and current checks at the breaker panels. One live circuit, part of the reactor interlock with the exhaust ventilation system, was discovered. Dismantlement work was delayed until the circuit was removed by ANL-E electricians. The technicians proceeded to cut the wires at the point where the wires entered the panels instead of disconnecting the wires, pulling the wires free of the panel and then cutting the wires. The technician, as part of what he believed to be an added measure of safety, was checking each wire after he cut it to verify it was deenergized.

This method led to two live wires being cut and subsequently capped with wire nuts. These wires had been installed in the early 1990's as part of the installation of an emergency power system. The emergency circuits had been incorrectly routed through the reactor control panels instead of through their own conduit. The problem was identified when it was noticed that, in the stairway, exit lights were off while emergency lights were on. Work was stopped and an investigation ordered by the project manager.

Failure to disconnect and remove each wire as described above was the primary cause of the event. Contributing to the problem were inadequate documentation of facility changes and improper routing of the wires. To prevent a recurrence of the problem, Afftrex provided additional electrical detection, equipment, enhanced procedures and increased personnel awareness. The severed wiring was rerouted through new conduit, and emergency circuits were reenergized. 
There were three lessons learned from this event:

- "As-built" drawings do not always reflect current conditions.

- The procedure should have been more detailed as to the method of wire removal.

- Personnel need to be continuously reminded that when conditions or events do not meet expectations, work must be stopped and management notified before work can continue.

\subsubsection{HEPA Filter Fire}

While cutting the steel shell with cut-off saws, a fire erupted in the contractor's portable HEPA ventilation system: Two D\&D) technicians working inside of a containment structure in the low-dose room were size-reducing sections of the steel shell using abrasive cut-off saws. A health physics technician was providing intermittent job coverage outside of the containment tent. The health physics technician entered the low-dose room and saw smoke. He directed the technicians working inside the containment tent to leave. They could not hear him clearly and, because they were wearing respiratory protection, they could not smell the smoke. The health physics technician was having difficulty breathing and left the area to get a fire extinguisher. The D\&D technicians heard the fire alarm sound and, as they were leaving the containment, one of them noticed that smoke was coming from the portable HEPA unit used to ventilate the tent. The D\&D technician nearest the HEPA unit shut the system down and opened the filter box. The prefilter was completely engulfed with fire. The technician emptied his fire extinguisher into the HEPA unit as all personnel evacuated the area. The ANL-E Fire Department responded to the fire alarm, entered the area and extinguished the fire with additional water.

Precautions had been taken prior to the event. A burn permit had been issued for the work, and all combustible material had been removed from the area. One D\&D technician acted as fire watch, using a metal shield to deflect sparks from the side of the tent. Because the HEPA intake was several feet away from the cutting area, it was thought to be safe. But since the fire started inside the HEPA unit, which was outside of the containment tent, the technician acting as fire watch was not aware of the problem.

All cutting work was stopped until the following corrective actions were implemented:

- An inexpensive metal spark arrester was installed on the HEPA intake line.

- The cloth pre-filters on all portable HEPA units were replaced with metal reusable prefilters.

- A household smoke detector was installed at the exhaust of all HEPA units to provide for early warning of a possible HEPA fire. 
It was determined that insufficient planning, inappropriate filter media and failure to recognize the possibility of a spark entering the HEPA system were the root causes of this event. The primary lesson learned was that special attention is required for preventing fires when any spark-producing work is to be done inside of HEPA-ventilated containments.

\subsubsection{Crane Damages Condensate Piping}

During removal of the floor plugs from above the reactor tank, the 10 ton (9.1 MT) crane struck and damaged a condensate line: Two D\&D technicians (one operating the crane and the second acting as a signal-person) were removing floor plugs from above the reactor and stacking them on the west side of the high bay. Due to the limited floor space, the technicians were attempting to place the plugs as far west as possible. The incident occurred during the removal of the third plug. It was being moved as far west as possible by putting the crane on the west-end stops so that the plug could be placed on the floor as far north and west as possible. The plug was being trolleyed north when an electrical box on the crane hit a condensate line and bent it. When the field engineer observed the contact, he ordered all crane movement stopped. The load was then trolleyed south and east, and set on the floor to establish a safe condition. The crane was locked and tagged out of service, and appropriate notifications made.

Investigation into the event revealed that the crane stops on the west end of the crane rail had been modified after original installation to allow the crane access to the high-dose room ceiling plugs. The interference between the crane and the condensate line had not been identified after the modifications.

Crane operation was stopped until the following corrective actions were taken:

- $\quad$ Red match marks were painted on the crane and crane rail at the west end of the high bay to alert operators that they were entering an area where interference could occur.

- All crane operators were informed of the interference.

- When the crane was operating in the west end of the high bay, a spotter was required to alert the crane operator of potential interference.

After inspection by ANL-E PFS, the crane was returned to service. Building 202 maintenance workers repaired the damaged condensate line.

The lesson learned from this event is that crane clearances should be verified before using the crane.

\subsubsection{Possible Near Miss Condition}

Wire attached to circuit breaker marked as a spare: As part of the JANUS D\&D project, ANL-E electricians were terminating wires from electrical panel XMQ2 Breakers 9 and 11 . On 
January 28, 1997, Breakers 9 and 11 had been LO/TO by JANUS Project personnel as part of the electrical isolation of equipment to be removed. A review of existing prints and diagrams had been made to identify circuits requiring LO/TO, and current/voltage checks were made on all wires. While removing the wires from the electrical panel, an electrician discovered a cut wire that had been attached to Breaker 13. He further discovered that Breaker 13 was open and not LO/TO as required. A review of the breaker listing for electrical panel XMQ2 revealed that Breaker 13 was a spare.

Modifications to the JANUS cooling tower had been made, and during past operations Breaker 13 had been used. The electrical panel and electrical diagrams were not updated to show the past use of this circuit.

This event was another instance of "as built" drawings not properly reflecting actual conditions. Since the breaker had been in the off position, the current/voltage checks did not reveal the potential hazard that was present. The lesson learned by this event is that panel inspections should be made to verify that no circuits are connected to "spare" breakers.

\subsection{Management Issues}

Only one management issue is worthy of note, e.g., the delay in receiving full funding prior to the start of the project. Contract award was originally scheduled for October 1996. Because full funding was not available until mid-December, a two-part contract award was made to allow the contractor to begin procedure preparation and mobilization activities in November. Once full funding was received in mid-December, a Notice to Proceed was issued to the contractor. Had a two-part contract award not been made, the project schedule could have been sufficiently delayed. ANL-E could have been placed into serious out-of-scope conditions, e.g., heat stress situations.

\subsection{Noteworthy Practices}

A number of noteworthy practices were identified during this project.

\subsubsection{Air Conditioning}

From late June through August, excessive temperature and humidity at the project site placed the workers into a heat stress situation. With the on-set of high-temperature conditions, worker stay times for tasks requiring protective clothing were severely curtailed. Scheduled work periods were reduced to 15 min with a required 45-min rest period after each work period. The contractor's schedule was severely jeopardized by these unanticipated delays. In an effort to limit the effects of heat stress, the contractor first fitted the workers with "cool vests." These provided temporary relief, but the added weight and bulk of the vest did not effectively increase production. The contractor then brought in a portable diesel-powered 20,000 BTU air conditioning unit and set it up outside of J-Wing. The cool air was directed into the containment and the ambient air temperature went from 
JANUS D\&D Project

Final Report

Page 101 of 111

$95^{\circ} \mathrm{F}$ to $75^{\circ} \mathrm{F}\left(35^{\circ} \mathrm{C}\right.$ to $\left.24^{\circ} \mathrm{C}\right)$ with a corresponding $35 \%$ decrease in humidity. The air conditioning unit eliminated heat stress conditions for the workers.

\subsubsection{Chain Saw Segmentation of Lead Block}

During removal of the lead wall in the high-dose room, an out-of-scope situation was identified by the contractor. The lead wall was thought to be constructed of 4 in $x 4$ in $\times 24$ in $(10.16 \mathrm{~cm} \mathrm{x}$ $10.16 \mathrm{~cm} \times 60.96 \mathrm{~cm}$ ) chevron-shaped lead block stacked and butted together, with the surface of the butts welded together to a depth of approximately $0.125 \mathrm{in}(0.305 \mathrm{~cm})$. It was discovered that the butts were actually welded the full depth $(4$ in $(10.16 \mathrm{~cm}))$ to each other and to a lead mounting plate bolted to the concrete wall. The contractor had originally planned to chisel the 0.125 in $(0.305 \mathrm{~cm})$ surface weld free to remove the block. This proved far more time consuming than planned. It became necessary to identify a faster removal method. After an extensive test program, it was concluded that a circular saw with a non-metallic cutting blade and a electric-powered chain saw, used in combination, were most effective. The circular saw was limited to a cut depth of only 3.5 in $(8.89 \mathrm{~cm})$ at 0.125 in $(0.305 \mathrm{~cm})$ cut depth per pass. Also, the circular saw was not capable of cutting in corners between walls. The chain saw was capable of making full 4 in $(10.16 \mathrm{~cm})$ deep cuts and accessing corners. Several nylon sprockets required replacement, but overall the chain saw performed well.

\subsubsection{Semi-Remote Concrete Removal}

Removal of high density concrete from around and above the reactor tank was more difficult than anticipated. The concrete had densities as high as $270 \mathrm{lb} / \mathrm{ft}^{3}\left(122.5 \mathrm{~kg} / 0.028 \mathrm{~m}^{3}\right)$ and was extremely hard. After several weeks of trying to remove concrete with $90 \mathrm{lb}(40.82 \mathrm{~kg}$ ) jackhammers, Afftrex contracted with Duane Equipment Corporation (Boston, Massachusetts) for a remotely operated BROKK 150 , equipped with a $750 \mathrm{lb}(340.2 \mathrm{~kg})$ jackhammer, and an operator. The BROKK 150 was compact enough to be lowered through the existing floor openings into the reactor cavity but powerful enough to effectively demolish the concrete. A clear-walled containment was constructed between the operator and work area, permitting the operator good visual contact with the BROKK machine and work area yet isolating him from concrete dust and falling rubble. The BROKK removed over $90 \%$ of the concrete in less than three weeks. In addition to demolishing the concrete, the BROKK 150 was equipped with an interchangeable bucket that was used to package the rubble into waste containers.

\subsubsection{Frequent Safety Inspections}

At the start of the project, formal safety inspections conducted by the project manager, ANL-E ESH Safety Engineering, and Afftrex were scheduled on a quarterly basis. For the first several months of the project, however, safety inspections were conducted monthly in order to underscore the importance of safety to all project personnel. After several inspections with no major problems identified, frequency was reduced to quarterly. Management's commitment to safety is effectively emphasized by frequently scheduled formal inspections. Project personnel became sensitized to management's commitment, resulting in a safer work place and in safety-conscious project personnel. 


\subsection{ACRONYM ANI ABBREVIATION LISTING}

ACM asbestos-containing materials

ALARA As Low As Reasonably Achievable

ANL-E

Argonne National Laboratory-East (located in Argonne, Illinois USA)

ANSI

ASA

American National Standards Institute

ASME

Auditable Safety Analysis

American Association of Mechanical Engineers

$\mathrm{Bq}$

Becquerel

$\mathrm{Ci}$

$\mathrm{cm}$

Curie

CAM

centimeter

${ }^{\circ} \mathrm{C}$

continuous air monitor

${ }^{\circ} \mathrm{F}$

degree Celius

degree Fahrenheit

D\&D Decontamination and Dismantlement (or Decontamination and Decommissioning)

DAC derived airborne concentration

DOE United States Department of Energy

DOE-ARG United States Department of Energy Argonne Group

DOE-CH United States Department of Energy Chicago Operations

DOE-EM United States Department of Energy Environmental Management

dpm

disintegrations per minute

EA Environmental Assessment

e.g. for example

EM-40 United States Department of Energy, Assistant Secretary for Environmental Management, Office of Environmental Restoration

EMO ANL-E Environmental Management Operations Division

ESH ANL-E Environment, Safety and Health Division

ESH/HP Environment, Safety and Health/Health Physics Group

ESH/QA Environment, Safety and Health/Quality Assurance Oversight

$\mathrm{ft}$ foot

g gram

gal gallon

GBq Giga Becquerel

g.p.m. gallons per minute

Gy Gray 


\begin{tabular}{|c|c|}
\hline HASP & Health and Safety Plan \\
\hline HEPA & High Efficiency Particulate Air \\
\hline $\mathrm{Hg}$ & mercury \\
\hline $\mathrm{HP}$ & horse power \\
\hline $\mathrm{hr}$ & hour \\
\hline i.e. & that is \\
\hline IH & Industrial Hygiene \\
\hline in & inch \\
\hline IEPA & Mlinois Environmental Protection Agency \\
\hline IVS & Independent Verification Survey \\
\hline $\mathrm{kg}$ & kilogram \\
\hline $\mathrm{km}$ & kilometer \\
\hline $\mathrm{kW}$ & kilowatt \\
\hline 1 & liter \\
\hline $\mathrm{lb}$ & pound \\
\hline $\mathrm{LO} / \mathrm{TO}$ & Lock Out/Tag Out \\
\hline l.p.m. & liters per minute \\
\hline $\mathrm{m}$ & meter \\
\hline $\mathrm{MBq}$ & mega Becquerel \\
\hline $\mathrm{mBq}$ & milli Becquerel \\
\hline $\mathrm{mCi}$ & microcurie \\
\hline $\min$ & minute \\
\hline $\mathrm{ml}$ & milliliter \\
\hline $\mathrm{mR}$ & milli Roentgen \\
\hline mrem & millirem \\
\hline $\mathrm{mSv}$ & milli Sievert \\
\hline MT & metric ton \\
\hline NIST & National Institute for Science and Technology \\
\hline NQA & Nuclear Quality Assurance \\
\hline OSHA & Occupational Safety and Health Administration \\
\hline ORISE & Oak Ridge Institute for Science and Education \\
\hline $\mathrm{pCi}$ & picocurie \\
\hline PFS & ANL-E Plant Facilities and Services Division \\
\hline QA & quality assurance \\
\hline QAR & Quality Assurance Representative \\
\hline
\end{tabular}




$\begin{array}{ll}\text { rad } & \text { radiation absorbed dose } \\ \text { rem } & \text { Roentgen equivalent man } \\ \text { RCT } & \text { Radiation Control Technician } \\ \text { RFP } & \text { Request for Proposal } \\ \text { RWP } & \text { Radiological Work Permit } \\ \text { sec } & \text { second } \\ \text { SRD } & \text { self reading dosimeter } \\ \text { TD } & \text { Argonne National Laboratory Technology Development Division } \\ \text { TLD } & \text { thermoluminescent dosimeter } \\ & \\ \text { WBS } & \text { Work Breakdown Structure } \\ \text { WMO } & \text { ANL-E Waste Management Operations }\end{array}$


APPENDIX I: WASTE VOLUMES

Table IA: Low-Level Waste from JANUS D\&D Project

Table IB: Mixed Waste from JANUS D\&D Project 
Table IA Low-Level Waste From JANUS D\&D Project

\begin{tabular}{|c|c|c|c|c|c|c|c|c|c|c|}
\hline \multirow[t]{2}{*}{ Cont. ID } & \multirow[t]{2}{*}{$\begin{array}{l}\text { Cont. } \\
\text { Type }\end{array}$} & \multicolumn{2}{|c|}{ Volume } & \multicolumn{2}{|c|}{ Weight } & \multicolumn{2}{|c|}{ Total Activity } & \multicolumn{2}{|c|}{$\begin{array}{c}\text { Dose Rate at } \\
1 \text { Meter }\end{array}$} & \multirow[t]{2}{*}{$\begin{array}{l}\text { Date } \\
\text { Pkgd. }\end{array}$} \\
\hline & & $\mathrm{m}^{3}$ & $\mathrm{ft}^{3}$ & $\mathrm{~kg}$ & $\mathrm{lb}$ & $\mathrm{MBq}$ & $\mathrm{mCi}$ & uSv/hr & $\mathrm{mrem} / \mathrm{hr}$ & \\
\hline NR4440? & $\begin{array}{l}2081(55 \\
\text { gal) drum }\end{array}$ & 0.21 & 7.5 & 249 & 549 & 0.074 & .002 & $<1.0$ & $<0.1$ & $4 / 11 / 97$ \\
\hline NR44415 & $\begin{array}{l}2081(55 \\
\text { gal) drum }\end{array}$ & 0.21 & 7.5 & 261 & 575 & 0.074 & .002 & $<1.0$ & $<0.1$ & $4 / 11 / 97$ \\
\hline NR44416 & $\begin{array}{l}208 \text { l (55 } \\
\text { gal) drum }\end{array}$ & 0.21 & 7.5 & 227 & 500 & 0.074 & .002 & $<1.0$ & $<0.1$ & $4 / 14 / 97$ \\
\hline NR44417 & B-12 Box & 1.25 & 44 & 1533 & 3380 & 178.192 & 4.816 & 10.0 & 1.0 & $5 / 9 / 97$ \\
\hline NR44418 & $\begin{array}{l}208 \text { I ( } 55 \\
\text { gal) drum }\end{array}$ & 0.21 & 7.5 & 238 & 525 & 10.878 & .294 & $<1.0$ & $<0.1$ & $4 / 15 / 97$ \\
\hline NR46201 & $\begin{array}{l}2081(55 \\
\text { gal) drum }\end{array}$ & 0.21 & 7.5 & 236 & 520 & 0.074 & .002 & $<1.0$ & $<0.1$ & $4 / 4 / 97$ \\
\hline NR46202 & B-25 Box & 2.55 & 90 & 2654 & 5851 & 3256.7 & 88.019 & 1.0 & 0.1 & $4 / 22 / 97$ \\
\hline NR46203 & B-25 Box & 2.55 & 90 & 2381 & 5249 & 2964.26 & 80.115 & $<1.0$ & $<0.1$ & $4 / 2 / 97$ \\
\hline NR46204 & $\begin{array}{l}2081(55 \\
\text { gal) drum }\end{array}$ & 0.21 & 7.5 & 255 & 562 & 0.074 & .002 & $<1.0$ & $<0.1$ & $4 / 2 / 97$ \\
\hline NR46205 & $\begin{array}{l}2081 \text { ( } 55 \\
\text { gal) drum }\end{array}$ & 0.21 & 7.5 & 236 & 520 & 0.074 & .002 & $<1.0$ & $<0.1$ & $4 / 2 / 97$ \\
\hline NR46206 & $\begin{array}{l}2081 \text { ( } 55 \\
\text { gal) drum }\end{array}$ & 0.21 & 7.5 & 218 & 481 & 0.074 & .002 & $<1.0$ & $<0.1$ & $4 / 2 / 97$ \\
\hline NR46207 & B-12 Box & 1.25 & 44 & 1542 & 3399 & 2003.85 & 54.158 & 20.0 & 2.0 & $5 / 6 / 97$ \\
\hline NR46208 & $\begin{array}{l}208 \mathrm{l}(55 \\
\text { gal) drum }\end{array}$ & 0.21 & 7.5 & 204 & 450 & 0.074 & .002 & $<1.0$ & $<0.1$ & $4 / 8 / 97$ \\
\hline NR46209 & $\begin{array}{l}2081(55 \\
\text { gal) drum } \\
\end{array}$ & 0.21 & 7.5 & 249 & 549 & 0.074 & .002 & $<1.0$ & $<0.1$ & $4 / 8 / 97$ \\
\hline NR46211 & $\begin{array}{l}2081(55 \\
\text { gal) drum }\end{array}$ & 0.21 & 7.5 & 249 & 549 & 0.074 & .002 & $<1.0$ & $<0.1$ & $4 / 10 / 97$ \\
\hline NR46212 & $\begin{array}{l}2081(55 \\
\text { gal) drum }\end{array}$ & 0.21 & 7.5 & 245 & 540 & 0.074 & .002 & $<1.0$ & $<0.1$ & $4 / 10 / 97$ \\
\hline NR46213 & $\begin{array}{l}2081(55 \\
\text { gal) drum } \\
\end{array}$ & 0.21 & 7.5 & 236 & 520 & 0.074 & .002 & $<1.0$ & $<0.1$ & $4 / 3 / 97$ \\
\hline NR46214 & $\begin{array}{l}2081(55 \\
\text { gal) drum }\end{array}$ & 0.21 & 7.5 & 236 & 520 & 0.074 & .002 & $<1.0$ & $<0.1$ & $4 / 3 / 97$ \\
\hline
\end{tabular}


Table IA Low-Level Waste From JANUS D\&D Project (cont.)

\begin{tabular}{|c|c|c|c|c|c|c|c|c|c|c|}
\hline \multirow[t]{2}{*}{ Cont. ID } & \multirow[t]{2}{*}{$\begin{array}{l}\text { Cont. } \\
\text { Type }\end{array}$} & \multicolumn{2}{|c|}{ Volume } & \multicolumn{2}{|c|}{ Weight } & \multicolumn{2}{|c|}{ Total Activity } & \multicolumn{2}{|c|}{$\begin{array}{c}\text { Dose Rate at } \\
1 \text { Meter }\end{array}$} & \multirow[t]{2}{*}{$\begin{array}{l}\text { Date } \\
\text { Plkgd. }\end{array}$} \\
\hline & & $\mathrm{m}^{3}$ & $\mathrm{ft}^{3}$ & $\mathrm{~kg}$ & $\mathrm{lb}$ & $\mathrm{MBq}$ & $\mathrm{mCi}$ & $\mathrm{uSv} / \mathrm{hr}$ & mrem/ & \\
\hline NR46215 & $\begin{array}{l}2081 \text { (55 } \\
\text { gal) drum }\end{array}$ & 0.21 & 7.5 & 214 & 472 & 0.074 & .002 & $<1.0$ & $<0.1$ & $4 / 4 / 97$ \\
\hline NR46216 & $\begin{array}{l}2081 \text { (55 } \\
\text { gal) drum }\end{array}$ & 0.21 & 7.5 & 218 & 481 & 0.074 & .002 & $<1.0$ & $<0.1$ & $4 / 4 / 97$ \\
\hline NR46531 & $\begin{array}{l}2081(55 \\
\text { gal) drum }\end{array}$ & 0.21 & 7.5 & 240 & 529 & 10.878 & .294 & $<1.0$ & $<0.1$ & $4 / 15 / 97$ \\
\hline NR46532 & $\begin{array}{l}2081(55 \\
\text { gal) drum }\end{array}$ & 0.21 & 7.5 & 259 & 571 & 10.915 & .295 & $<1.0$ & $<0.1$ & $4 / 15 / 97$ \\
\hline NR46533 & $\begin{array}{l}2081 \text { ( } 55 \\
\text { gal) drum }\end{array}$ & 0.21 & 7.5 & 204 & 450 & 0.074 & .002 & $<1.0$ & $<0.1$ & $4 / 15 / 97$ \\
\hline NR46534 & $\begin{array}{l}2081(55 \\
\text { gal) drum }\end{array}$ & 0.21 & 7.5 & 200 & 441 & 0.074 & .002 & $<1.0$ & $<0.1$ & $4 / 15 / 97$ \\
\hline NR46535 & B-12 Box & 1.25 & 44 & 1452 & 3201 & 154.29 & 4.170 & 50.0 & 5.0 & $6 / 2 / 97$ \\
\hline NR46536 & B-12 Box & 1.25 & 44 & 975 & 2149 & 541.939 & 14.647 & $<1.0$ & $<0.1$ & $7 / 3 / 97$ \\
\hline NR46725 & B-12 Box & 1.25 & 44 & 1452 & 3201 & 1748.47 & 47.256 & $<1.0$ & $<0.1$ & $7 / 22 / 97$ \\
\hline NR46727 & B-12 Box & 1.25 & 44 & 1270 & 2800 & 3070.48 & 82.986 & 3.0 & 0.3 & $7 / 25 / 97$ \\
\hline NR46728 & B-12 Box & 1.36 & 48 & 2948 & 6499 & 29233.7 & 790.100 & 2.0 & 0.2 & $8 / 1 / 97$ \\
\hline NR46729 & B-12 Box & 1.25 & 44 & 1724 & 3801 & 2885.56 & 77.988 & $<1.0$ & $<0.1$ & $7 / 30 / 97$ \\
\hline NR46730 & B-12 Box & 1.25 & 44 & 1597 & 3521 & 4.81 & .130 & $<1.0$ & $<0.1$ & $8 / 5 / 97$ \\
\hline NR46731 & B-12 Box & 1.25 & 44 & 1633 & 3600 & 56.129 & 1.517 & $<1.0$ & $<0.1$ & $8 / 5 / 97$ \\
\hline NR46732 & B-12 Box & 1.25 & 44 & 1814 & 3999 & 1445.74 & 39.074 & $<1.0$ & $<0.1$ & $8 / 5 / 97$ \\
\hline NR46733 & $\begin{array}{l}2081(55 \\
\text { gal) drum }\end{array}$ & 0.21 & 7.5 & 238 & 525 & 9.25 & .250 & 1.0 & 0.1 & $7 / 8 / 97$ \\
\hline NR46734 & B-12 Box & 1.25 & 44 & 953 & 2101 & 0.333 & .009 & $<1.0$ & $<0.1$ & $6 / 13 / 97$ \\
\hline NR46735 & B-12 Box & 1.25 & 44 & 817 & 1801 & 0.148 & .004 & 1.0 & 0.1 & $6 / 13 / 97$ \\
\hline NR46736 & B-12 Box & 1.36 & 48 & 1134 & 2500 & 0.333 & .009 & $<1.0$ & $<0.1$ & $6 / 13 / 97$ \\
\hline NR46737 & B-12 Box & 1.36 & 48 & 1111 & 2449 & 0.296 & .008 & $<1.0$ & $<0.1$ & $6 / 17 / 97$ \\
\hline NR46738 & B-12 Box & 1.36 & 48 & 1406 & 3100 & 2043.44 & 55.228 & $<1.0$ & 0.1 & $7 / 3 / 97$ \\
\hline NR46739 & $\begin{array}{l}2081(55 \\
\text { gal) drum }\end{array}$ & 0.21 & 7.5 & 363 & 800 & 1.258 & .034 & $<1.0$ & $<0.1$ & $7 / 3 / 97$ \\
\hline NR46741 & $\begin{array}{l}2081 \text { I (55 } \\
\text { gal) drum }\end{array}$ & 0.21 & 7.5 & 327 & 721 & 1.073 & .029 & $<1.0$ & $<0.1$ & $7 / 3 / 97$ \\
\hline NR46742 & $\begin{array}{l}2081 \text { ( } 55 \\
\text { gal) drum }\end{array}$ & 0.21 & 7.5 & 327 & 721 & 1.036 & .028 & $<1.0$ & $<0.1$ & $7 / 3 / 97$ \\
\hline
\end{tabular}


Table IA Low-Level Waste From JANUS D\&D Project (cont.)

\begin{tabular}{|c|c|c|c|c|c|c|c|c|c|c|}
\hline \multirow[t]{2}{*}{ Cont. ID } & \multirow[t]{2}{*}{$\begin{array}{l}\text { Cont. } \\
\text { Type }\end{array}$} & \multicolumn{2}{|c|}{ Volume } & \multicolumn{2}{|c|}{ Weight } & \multicolumn{2}{|c|}{ Total Activity } & \multicolumn{2}{|c|}{$\begin{array}{c}\text { Dose Rate at } \\
1 \text { Meter }\end{array}$} & \multirow[t]{2}{*}{$\begin{array}{l}\text { Date } \\
\text { Pkgd. }\end{array}$} \\
\hline & & $\mathrm{m}^{3}$ & $\mathrm{ft}^{3}$ & $\mathrm{~kg}$ & $\mathrm{lb}$ & $\mathrm{MBq}$ & $\mathrm{mCi}$ & $\mathrm{uSv} / \mathrm{hr}$ & mrem/ & \\
\hline NR46743 & $\begin{array}{l}2081(55 \\
\text { gal) drum }\end{array}$ & 0.21 & 7.5 & 345 & 761 & 1.11 & .030 & $<1.0$ & $<0.1$ & $7 / 3 / 97$ \\
\hline NR46744 & $\begin{array}{l}2081 \text { ( } 55 \\
\text { gal) drum }\end{array}$ & 0.21 & 7.5 & 308 & 679 & 0.999 & .027 & $<1.0$ & $<0.1$ & $7 / 7 / 97$ \\
\hline NR46745 & B- 25 Box & 2.55 & 90 & 2790 & 6151 & 7942.79 & 214.670 & 170.0 & 17.0 & $5 / 12 / 97$ \\
\hline NR46746 & B-12 Box & 1.36 & 48 & 1633 & 3600 & 1971.32 & 53.279 & 60.0 & 6.0 & $5 / 13 / 97$ \\
\hline NR46747 & B-12 Box & 1.36 & 48 & 1455 & 3208 & 224.257 & 6.061 & 90.0 & 9.0 & $5 / 29 / 97$ \\
\hline NR46748 & $\begin{array}{l}2081 \text { ( } 55 \\
\text { gal) drum }\end{array}$ & 0.21 & 7.5 & 340 & 750 & 1.11 & .030 & $<1.0$ & $<0.1$ & $5 / 28 / 97$ \\
\hline NR46749 & $\begin{array}{l}2081(55 \\
\text { gal) drum }\end{array}$ & 0.21 & 7.5 & 363 & 800 & 1.147 & .031 & $<1.0$ & $<0.1$ & $5 / 28 / 9 /$ \\
\hline NR46750 & $\begin{array}{l}2081(55 \\
\text { gal) drum }\end{array}$ & 0.21 & 7.5 & 363 & 800 & 1.073 & .029 & $<1.0$ & $<0.1$ & $5 / 28 / 97$ \\
\hline NR46756 & $\begin{array}{l}2081 \text { ( } 55 \\
\text { gal) drum }\end{array}$ & 0.21 & 7.5 & 363 & 800 & 1.184 & .032 & $<1.0$ & $<0.1$ & $6 / 20 / 97$ \\
\hline NR47190 & $\begin{array}{l}\mathrm{M} 3 \mathrm{Al} / 2 \\
\mathrm{Bin}\end{array}$ & 1.87 & 66 & 1905 & 4200 & 3900.39 & 105.416 & $<1.0$ & $<0.1$ & $9 / 19 / 97$ \\
\hline NR47191 & B-25 Box & 2.55 & 90 & 2286 & 5040 & 2717.21 & 73.438 & $<1.0$ & $<0.1$ & 9/25/97 \\
\hline NR47195 & $\begin{array}{l}\mathrm{M} 3 \mathrm{~A} 1 / 2 \\
\mathrm{Bin}\end{array}$ & 1.87 & 66 & 3901 & 8600 & 45.769 & 1.237 & $<1.0$ & $<0.1$ & $9 / 15 / 97$ \\
\hline NR47196 & $\begin{array}{l}\mathrm{M} 3 \mathrm{~A} 1 / 2 \\
\mathrm{Bin}\end{array}$ & 1.87 & 66 & 3538 & 7800 & 1260.89 & 34.078 & $<1.0$ & $<0.1$ & $9 / 15 / 97$ \\
\hline NR47197 & $\begin{array}{l}\mathrm{M} 3 \mathrm{~A} 1 / 2 \\
\mathrm{Bin}\end{array}$ & 1.87 & 66 & 3992 & 8801 & 111.444 & 3.012 & $<1.0$ & $<0.1$ & $9 / 15 / 97$ \\
\hline NR47198 & $\begin{array}{l}2081(55 \\
\text { gal) drum }\end{array}$ & 0.21 & 7.5 & 363 & 800 & 9.324 & .252 & $<1.0$ & $<0.1$ & $9 / 19 / 97$ \\
\hline NR47199 & $\begin{array}{l}2081(55 \\
\text { gal) drum }\end{array}$ & 0.21 & 7.5 & 318 & 701 & 9.139 & .247 & $<1.0$ & $<0.1$ & $9 / 19 / 97$ \\
\hline NR47200 & $\begin{array}{l}2081(55 \\
\text { gal) drum }\end{array}$ & 0.21 & 7.5 & 340 & 750 & 82.695 & 2.235 & $<1.0$ & $<0.1$ & $9 / 19 / 97$ \\
\hline NR47251 & B-12 Box & 1.25 & 44 & 1325 & 2921 & 1505.72 & 40.695 & $<1.0$ & $<0.1$ & $7 / 14 / 97$ \\
\hline NR47252 & B-12 Box & 1.25 & 44 & 1361 & 3000 & 416.62 & 11.260 & $<1.0$ & $<0.1$ & $8 / 8 / 97$ \\
\hline NR47253 & B-12 Box & 1.25 & 44 & 1524 & 3360 & 1653.83 & 44.698 & $<1.0$ & $<0.1$ & $8 / 8 / 97$ \\
\hline NR47254 & B-12 Box & 1.25 & 44 & 1724 & 3801 & 2450.03 & 66.217 & $<1.0$ & $<0.1$ & $8 / 11 / 97$ \\
\hline NR47255 & B-12 Box & 1.25 & 44 & 1542 & 3399 & 2538.02 & 68.595 & $<1.0$ & $<0.1$ & $8 / 18 / 97$ \\
\hline
\end{tabular}


Table IA Low-Level Waste From JANUS D\&D Project (cont.)

\begin{tabular}{|c|c|c|c|c|c|c|c|c|c|c|}
\hline \multirow[t]{2}{*}{ Cont. ID } & \multirow[t]{2}{*}{$\begin{array}{l}\text { Cont. } \\
\text { Type }\end{array}$} & \multicolumn{2}{|c|}{ Volume } & \multicolumn{2}{|c|}{ Weight } & \multicolumn{2}{|c|}{ Total Activity } & \multicolumn{2}{|c|}{$\begin{array}{c}\text { Dose Rate at } \\
1 \text { Meter }\end{array}$} & \multirow[t]{2}{*}{$\begin{array}{l}\text { Date } \\
\text { Pkgd. }\end{array}$} \\
\hline & & $\mathrm{m}^{3}$ & $\mathrm{ft}^{3}$ & $\mathrm{~kg}$ & $\mathrm{lb}$ & $\mathrm{MBq}$ & $\mathrm{mCi}$ & $\mathrm{uSv} / \mathrm{hr}$ & mrem/ & \\
\hline NR47256 & B-12 Box & 1.25 & 44 & 1905 & 4200 & 1442.82 & 38.995 & $<1.0$ & $<0.1$ & $8 / 25 / 97$ \\
\hline NR47257 & B-12 Box & 1.25 & 44 & 1724 & 3801 & 5.106 & .138 & $<1.0$ & $<0.1$ & $8 / 25 / 97$ \\
\hline NR47258 & B-12 Box & 1.25 & 44 & 1860 & 4101 & 5.661 & .153 & $<1.0$ & $<0.1$ & $8 / 25 / 97$ \\
\hline NR47259 & B-12 Box & 1.25 & 44 & 1905 & 4200 & 87.579 & 2.367 & $<1.0$ & $<0.1$ & $8 / 25 / 97$ \\
\hline NR47260 & B-12 Box & 1.25 & 44 & 1996 & 4400 & 55.13 & 1.490 & $<1.0$ & $<0.1$ & $8 / 25 / 97$ \\
\hline NR47261 & B-12 Box & 1.25 & 44 & 2041 & 4500 & 6.327 & .171 & $<1.0$ & $<0.1$ & $8 / 25 / 97$ \\
\hline NR47262 & B-12 Box & 1.25 & 44 & 1996 & 4400 & 6.179 & .167 & $<1.0$ & $<0.1$ & $8 / 25 / 97$ \\
\hline NR47263 & B-12 Box & 1.25 & 44 & 1814 & 3999 & 2114.7 & 57.154 & $<1.0$ & $<0.1$ & 9/3/97 \\
\hline NR47264 & B-12 Box & 1.25 & 44 & 2268 & 5000 & 7.326 & .198 & $<1.0$ & $<0.1$ & $9 / 3 / 97$ \\
\hline NR47265 & B-12 Box & 1.25 & 44 & 2268 & 5000 & 333.703 & 9.019 & $<1.0$ & $<0.1$ & $9 / 3 / 97$ \\
\hline NR47266 & B-12 Box & 1.25 & 44 & 2086 & 4599 & 496.466 & 13.418 & $<1.0$ & $<0.1$ & $9 / 3 / 97$ \\
\hline NR47267 & B-12 Box & 1.25 & 44 & 2268 & 5000 & 7.141 & .193 & $<1.0$ & $<0.1$ & 9/3/97 \\
\hline NR47268 & B-12 Box & 1.25 & 44 & 2268 & 5000 & 170.755 & 4.615 & $<1.0$ & $<0.1$ & $9 / 3 / 97$ \\
\hline NR47269 & B-12 Box & 1.25 & 44 & 1996 & 4400 & 5.994 & .162 & $<1.0$ & $<0.1$ & 9/3/97 \\
\hline NR47270 & $\begin{array}{l}2081 \text { ( } 55 \\
\text { gal) drum }\end{array}$ & 0.21 & 7.5 & 327 & 721 & 0.999 & .027 & $<1.0$ & $<0.1$ & $7 / 11 / 97$ \\
\hline NR47301 & B-12 Box & 1.25 & 44 & 1724 & 3801 & 1614.87 & 43.645 & $<1.0$ & $<0.1$ & $9 / 3 / 97$ \\
\hline $\mathrm{NR} 47302$ & B-12 Box & 1.25 & 44 & 2087 & 4601 & 50.357 & 1.361 & $<1.0$ & $<0.1$ & $9 / 3 / 97$ \\
\hline NR47303 & B-12 Box & 1.25 & 44 & 2041 & 4500 & 6.253 & .169 & $<1.0$ & $<0.1$ & $9 / 3 / 97$ \\
\hline NR47304 & B-12 Box & 1.25 & 44 & 1996 & 4400 & 22.2 & .600 & $<1.0$ & $<0.1$ & $9 / 3 / 97$ \\
\hline NR47305 & B-12 Box & 1.25 & 44 & 2177 & 4799 & 22.977 & .621 & $<1.0$ & $<0.1$ & $9 / 3 / 97$ \\
\hline NR47306 & $\begin{array}{l}\mathrm{M} 3 \mathrm{~A} 1 / 2 \\
\mathrm{Bin}\end{array}$ & 1.92 & 67.8 & 3266 & 7200 & 1055.5 & 28.527 & $<1.0$ & $<0.1$ & $9 / 9 / 97$ \\
\hline NR47307 & $\begin{array}{l}\mathrm{M} 3 \mathrm{Al} / 2 \\
\mathrm{Bin}\end{array}$ & 1.92 & 67.8 & 3810 & 8399 & 61.457 & 1.661 & $<1.0$ & $<0.1$ & $9 / 9 / 97$ \\
\hline NR47308 & B-12 Box & 1.25 & 44 & 2087 & 4601 & 39.183 & 1.059 & $<1.0$ & $<0.1$ & 9/9/97 \\
\hline NR47309 & B-12 Box & 1.25 & 44 & 2041 & 4500 & 912.494 & 24.662 & $<1.0$ & $<0.1$ & 9/9/97 \\
\hline NR47310 & B-12 Box & 1.25 & 44 & 1905 & 4200 & 152.551 & 4.123 & $<1.0$ & $<0.1$ & 9/9/97 \\
\hline NR47311 & B-12 Box & 1.25 & 44 & 2268 & 5000 & 292.966 & 7.918 & $<1.0$ & $<0.1$ & $9 / 15 / 97$ \\
\hline NR47312 & B-25 Box & 2.55 & 90 & 2449 & 5399 & 866.355 & 23.415 & 2.0 & 0.2 & $9 / 15 / 97$ \\
\hline NR47313 & B-12 Box & 1.25 & 44 & 1089 & 2401 & 1940.28 & 52.440 & $<1.0$ & $<0.1$ & $9 / 15 / 97$ \\
\hline
\end{tabular}


Table IA Low-Level Waste From JANUS D\&D Project (cont.)

\begin{tabular}{|c|c|c|c|c|c|c|c|c|c|c|}
\hline \multirow[t]{2}{*}{ Cont. ID } & \multirow[t]{2}{*}{$\begin{array}{l}\text { Cont. } \\
\text { Type }\end{array}$} & \multicolumn{2}{|c|}{ Volune } & \multicolumn{2}{|c|}{ Weight } & \multicolumn{2}{|c|}{ Total Activity } & \multicolumn{2}{|c|}{$\begin{array}{c}\text { Dose Rate at } \\
1 \text { Meter }\end{array}$} & \multirow[t]{2}{*}{$\begin{array}{r}\text { Date } \\
\text { Pkgd. }\end{array}$} \\
\hline & & $\mathrm{m}^{3}$ & $\mathrm{ft}^{3}$ & $\mathrm{~kg}$ & $\mathrm{lb}$ & $\mathrm{MBg}$ & $\mathrm{mCi}$ & uSv/hr & mrem/ & \\
\hline NR47314 & $\begin{array}{l}\mathrm{M} 3 \mathrm{~A} 1 / 2 \\
\mathrm{Bin}\end{array}$ & 1.87 & 66 & 3538 & 7800 & 1317.13 & 35.598 & $<1.0$ & $<0.1$ & $9 / 15 / 97$ \\
\hline NR47315 & $\begin{array}{l}\mathrm{M} 3 \mathrm{~A} 1 / 2 \\
\mathrm{Bin}\end{array}$ & 1.87 & 66 & 4173 & 9200 & 46.879 & 1.267 & $<1.0$ & $<0.1$ & $9 / 15 / 97$ \\
\hline RW29609 & $(5 \times 5)$ Box & 1.64 & 58 & 4287 & 9451 & 12860.6 & 347.585 & 70.0 & 7.0 & $5 / 9 / 97$ \\
\hline RW29610 & B-12 Box & 1.25 & 44 & 1497 & 3300 & 157.435 & 4.255 & 165.0 & 16.5 & $6 / 2 / 97$ \\
\hline RW29611 & B-12 Box & 1.25 & 44 & 1452 & 3201 & 154.29 & 4.170 & 200.0 & 20.0 & $6 / 2 / 97$ \\
\hline RW29612 & B-12 Box & 1.25 & 44 & 1497 & 3300 & 157.435 & 4.255 & 50.0 & 5.0 & $6 / 2 / 97$ \\
\hline RW29613 & B-12 Box & 1.25 & 44 & 1157 & 2551 & 656.417 & 17.741 & 10.0 & 1.0 & $6 / 2 / 97$ \\
\hline RW29639 & B-12 Box & 1.36 & 48 & 1837 & 4050 & 203.722 & 5.506 & 90.0 & 9.0 & $5 / 29 / 97$ \\
\hline RW29640 & B-12 Box & 1.25 & 44 & 1429 & 3150 & 145.077 & 3.921 & $<1.0$ & $<0.1$ & $5 / 30 / 97$ \\
\hline RW73133 & B-25 Box & 2.55 & 90 & 2540 & 5600 & 3014.35 & 81.469 & 1300.0 & 130.0 & $5 / 2 / 97$ \\
\hline RW73141 & B-12 Box & 1.25 & 44 & 1542 & 3399 & 160.543 & 4.339 & $<1.0$ & $<0.1$ & $5 / 30 / 97$ \\
\hline RW73434 & B-12 Box & 1.25 & 44 & 1497 & 3300 & 3587.63 & 96.963 & $<1.0$ & $<0.1$ & $6 / 5 / 97$ \\
\hline RW73435 & B-12 Box & 1.25 & 44 & 1270 & 2800 & 1883.08 & 50.894 & 2.0 & 0.2 & $7 / 8 / 97$ \\
\hline RW73436 & B-12 Box & 1.25 & 44 & 835 & 1841 & 792.503 & 21.419 & $<1.0$ & $<0.1$ & $7 / 3 / 97$ \\
\hline RW73440 & $\begin{array}{l}2081 \text { l (55 } \\
\text { gal) drum }\end{array}$ & 0.21 & 7.5 & 399 & 880 & 1.11 & .030 & $<1.0$ & $<0.1$ & $7 / 14 / 97$ \\
\hline RW7344l & $\begin{array}{l}208 \text { I (55 } \\
\text { gal) drum }\end{array}$ & 0.21 & 7.5 & 363 & 800 & 0.888 & .024 & $<1.0$ & $<0.1$ & $7 / 11 / 97$ \\
\hline RW73442 & $\begin{array}{l}208 \text { I (55 } \\
\text { gal) drum }\end{array}$ & 0.21 & 7.5 & 399 & 880 & 1.11 & .030 & $<1.0$ & $<0.1$ & $7 / 11 / 97$ \\
\hline RW73443 & $\begin{array}{l}2081(55 \\
\text { gal) drum }\end{array}$ & 0.21 & 7.5 & 227 & 500 & 0.703 & .019 & $<1.0$ & $<0.1$ & $7 / 8 / 97$ \\
\hline RW73444 & $\begin{array}{l}2081(55 \\
\text { gal) drum }\end{array}$ & 0.21 & 7.5 & 263 & 580 & 0.777 & .021 & $<1.0$ & $<0.1$ & $7 / 8 / 97$ \\
\hline RW73445 & B-12 Box & 1.25 & 44 & 1470 & 3241 & 2511.6 & 67.881 & 13.0 & 1.3 & $7 / 11 / 97$ \\
\hline TOT & & 113.46 & 4.002 .1 & 155738 & 343338 & 115918 & 3132.92 & & & \\
\hline
\end{tabular}


Table IB Mixed Waste From JANUS D\&D Project

\begin{tabular}{|c|c|c|c|c|c|c|c|c|c|c|}
\hline \multirow[t]{2}{*}{ Cont. ID } & \multirow[t]{2}{*}{$\begin{array}{l}\text { Cont. } \\
\text { Type }\end{array}$} & \multicolumn{2}{|c|}{ Volume } & \multicolumn{2}{|c|}{ Weight } & \multicolumn{2}{|c|}{$\begin{array}{c}\text { Total } \\
\text { Activity }\end{array}$} & \multicolumn{2}{|c|}{$\begin{array}{c}\text { Dose Rate at } \\
1 \text { Meter }\end{array}$} & \multirow[t]{2}{*}{$\begin{array}{l}\text { Date } \\
\text { Pkgd. }\end{array}$} \\
\hline & & $\mathrm{m}^{3}$ & $\mathrm{ft}^{3}$ & $\mathrm{~kg}$ & lb & $\mathrm{MBq}$ & $\mathrm{mCi}$ & $\mathrm{uSv} / \mathrm{hr}$ & mrem $/ \mathrm{h}$ & \\
\hline RW29608 & B-12 Box & 1.25 & 44 & 2631 & 5800.26 & 0.074 & 0.002 & $<1.0$ & $<0.1$ & $5 / 8 / 97$ \\
\hline RW29641 & $\begin{array}{l}2081 \text { ( } 55 \\
\text { gal) drum }\end{array}$ & 0.21 & 7.5 & $\mathrm{~N} / \mathrm{A}$ & $\mathrm{N} / \mathrm{A}$ & N/A & N/A & $<1.0$ & $<0.1$ & $5 / 29 / 97$ \\
\hline RW29642 & $\begin{array}{l}2081 \text { ( } 55 \\
\text { gal) drum }\end{array}$ & 0.21 & 7.5 & N/A & N/A & N/A & N/A & $<1.0$ & $<0.1$ & $5 / 29 / 97$ \\
\hline RW29650 & B-12 Box & 1.25 & 44 & N/A & N/A & N/A & N/A & $<1.0$ & $<0.1$ & $5 / 29 / 97$ \\
\hline RW71148 & B-12 Box & 1.25 & 44 & 2223 & 4900.79 & 409.072 & 11.056 & $<1.0$ & $<0.1$ & $7 / 24 / 97$ \\
\hline RW71149 & B-12 Box & 1.25 & 44 & 2223 & 4900.79 & 246.79 & 6.67 & $<1.0$ & $<0.1$ & $7 / 29 / 97$ \\
\hline RW71150 & B-12 Box & 1.25 & 44 & 2336 & 5149.91 & 231.583 & 6.259 & $<1.0$ & $<0.1$ & $8 / 11 / 97$ \\
\hline RW71151 & B-12 Box & 1.25 & 44 & 1406 & 3099.65 & 86.765 & 2.345 & $<1.0$ & $<0.1$ & $8 / 18 / 97$ \\
\hline RW71152 & B-12 Box & 1.36 & 48 & 1833 & 4041.01 & 1307.88 & 35.348 & $<1.0$ & $<0.1$ & $9 / 15 / 97$ \\
\hline RW73437 & B-12 Box & 1.25 & 44 & 2359 & 5200.62 & 2.183 & 0.059 & $<1.0$ & $<0.1$ & $7 / 14 / 97$ \\
\hline RW73439 & $\begin{array}{l}2081 \text { ( } 55 \\
\text { gal) drum }\end{array}$ & 0.21 & 7.5 & 345 & 760.582 & 0.962 & 0.026 & $<1.0$ & $<0.1$ & $7 / 22 / 97$ \\
\hline RW73446 & B-12 Box & 1.25 & 44 & 2200 & 4850.09 & 221.26 & 5.98 & $<1.0$ & $<0.1$ & $7 / 22 / 97$ \\
\hline RW74662 & B-12 Box & 1.36 & 48 & 2912 & 6419.75 & 3024.38 & 81.74 & 1.5 & 0.15 & $9 / 15 / 97$ \\
\hline RW74700 & $\begin{array}{l}\mathrm{M} 3 \mathrm{~A} 1 / 2 \\
\mathrm{Bin}\end{array}$ & 1.70 & 60 & 817 & 1801.15 & 686.535 & 18.555 & $<1.0$ & $<0.1$ & $9 / 25 / 97$ \\
\hline RW74701 & $\begin{array}{l}2081 \text { ( } 55 \\
\text { gal) drum }\end{array}$ & 0.21 & 7.5 & 45 & 99.2063 & 0 & 0 & $<1.0$ & $<0.1$ & $9 / 26 / 97$ \\
\hline \multicolumn{2}{|c|}{ Totals } & 15.24 & 538 & 21330 & 47023.8 & 6217.48 & 168.04 & & & \\
\hline
\end{tabular}

